\title{
Addition to inhaled corticosteroids of long-acting beta2- agonists versus anti-leukotrienes for chronic asthma (Review)
}

Ducharme FM, Lasserson TJ, Cates CJ

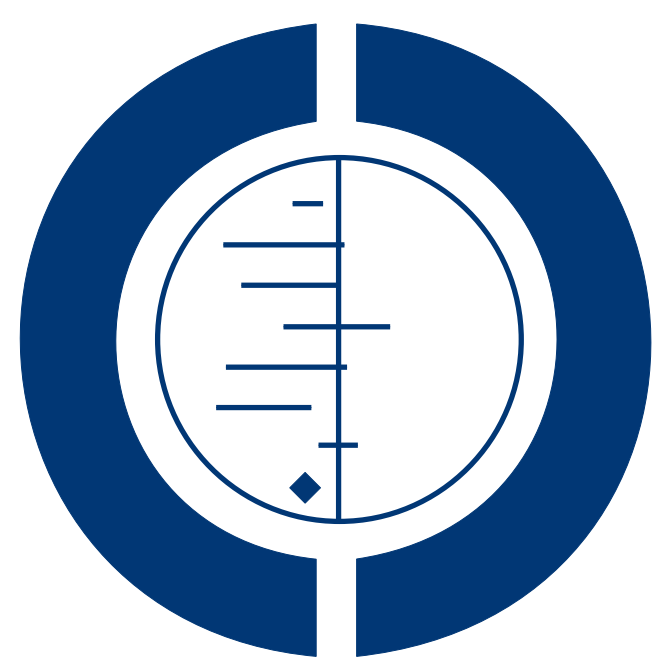

\section{THE COCHRANE COLLABORATION $^{\circledR}$}

This is a reprint of a Cochrane review, prepared and maintained by The Cochrane Collaboration and published in The Cochrane Library 2011, Issue 8

http://www.thecochranelibrary.com

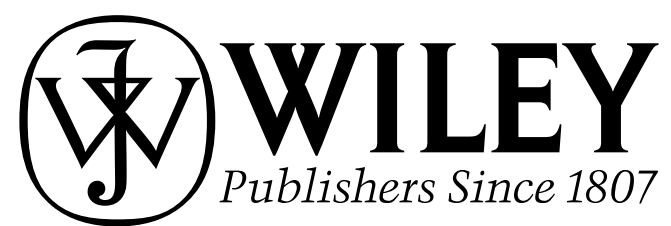

Addition to inhaled corticosteroids of long-acting beta2-agonists versus anti-leukotrienes for chronic asthma (Review)

Copyright (C) 201 I The Cochrane Collaboration. Published by John Wiley \& Sons, Ltd. 
TABLE OF CONTENTS

HEADER . . . . . . . . . . . . . . . . . . . . . . . . . . . . . . . 1

ABSTRACT .. . . . . . . . . . . . . . . . . . . . . . . . . . . . . . . . . . . . . . . . . . . . . . . . .

PLAIN LANGUAGE SUMMARY . . . . . . . . . . . . . . . . . . . . . . . . . . . . . . . . . . . $\quad$. 2

BACKGROUND . . . . . . . . . . . . . . . . . . . . . . . . . . . . . . . . . . . . . 2

OBJECTIVES . . . . . . . . . . . . . . . . . . . . . . . . . . . . . . . . . . . . . 3

METHODS . . . . . . . . . . . . . . . . . . . . . . . . . . . . . . . . . . . . . . 3

RESULTS . . . . . . . . . . . . . . . . . . . . . . . . . . . . . . . . . . . . . . . 5

Figure 1. . . . . . . . . . . . . . . . . . . . . . . . . . . . . . . . . . . . . . 6

Figure 2. . . . . . . . . . . . . . . . . . . . . . . . . . . . . . . . . . . . . . 9

Figure 3. . . . . . . . . . . . . . . . . . . . . . . . . . . . . . . . . . . . . . 11

Figure 4. . . . . . . . . . . . . . . . . . . . . . . . . . . . . . . . . . . . . . 12

Figure 5. . . . . . . . . . . . . . . . . . . . . . . . . . . . . . . . . . . . . 13

Figure 6. . . . . . . . . . . . . . . . . . . . . . . . . . . . . . . . . . . . . . 16

DISCUSSION . . . . . . . . . . . . . . . . . . . . . . . . . . . . . . . . . . . . . . . . . . . . . . 17

AUTHORS' CONCLUSIONS . . . . . . . . . . . . . . . . . . . . . . . . . . . . . . . . . . . . . . . 19

ACKNOWLEDGEMENTS . . . . . . . . . . . . . . . . . . . . . . . . . . . . . . . . . . . . . . . . . 19

REFERENCES . . . . . . . . . . . . . . . . . . . . . . . . . . . . . . . . . . . . 20

CHARACTERISTICS OF STUDIES . . . . . . . . . . . . . . . . . . . . . . . . . . . . . . . 32

DATA AND ANALYSES . . . . . . . . . . . . . . . . . . . . . . . . . . . . . . . . . . . . . . . . . . . 77

Analysis 1.1. Comparison 1 Long-acting ß2-agonists + ICS versus leukotriene receptor antagonists + ICS, Outcome 1

Participants with one or more exacerbations requiring systemic corticosteroids.

Analysis 1.2. Comparison 1 Long-acting ß2-agonists + ICS versus leukotriene receptor antagonists + ICS, Outcome 2 Morning PEF: $\mathrm{L} / \mathrm{min}$ change from baseline. . . . . . . . . . . . . . . . . . . . . . . .

Analysis 1.3. Comparison 1 Long-acting B2-agonists + ICS versus leukotriene receptor antagonists + ICS, Outcome 3 Evening PEF: $\mathrm{L} / \mathrm{min}$ change from baseline. . . . . . . . . . . . . . . . . . . . . . . . . . .

Analysis 1.4. Comparison 1 Long-acting ß2-agonists + ICS versus leukotriene receptor antagonists + ICS, Outcome 4 FEV1: L change from baseline. . . . . . . . . . . . . . . . . . . . . . . . . . . . .

Analysis 1.5. Comparison 1 Long-acting B2-agonists + ICS versus leukotriene receptor antagonists + ICS, Outcome 5 FEV1: L \% change from baseline. . . . . . . . . . . . . . . . . . . . . . . . . . . . . . . . .

Analysis 1.6. Comparison 1 Long-acting ß2-agonists + ICS versus leukotriene receptor antagonists + ICS, Outcome 6 FEV1: \% predicted end of treatment. . . . . . . . . . . . . . . . . . . . . . . . . . . . . . . . . . . .

Analysis 1.7. Comparison 1 Long-acting ß2-agonists + ICS versus leukotriene receptor antagonists + ICS, Outcome $7 \%$

fall in FEV1 POST-EXERCISE.
Analysis 1.8. Comparison 1 Long-acting 82 -agonists + + ICS versus leukotriene receptor antagonists + ICS, Outcome 8 Rescue-free days: $\%$ change from baseline. . . . . . . . . . . . . . . . . . . . . . . . . . . . . . . .

Analysis 1.9. Comparison 1 Long-acting ß2-agonists + ICS versus leukotriene receptor antagonists + ICS, Outcome 9 Rescue medication use: puffs/day change from baseline. . . . . . . . . . . . . . . . . . . . . .

Analysis 1.10. Comparison 1 Long-acting ß2-agonists + ICS versus leukotriene receptor antagonists + ICS, Outcome 10 Change in Global asthma QoL AQLQ Score (higher is better) - change from baseline. . . . . . . . . .

Analysis 1.11. Comparison 1 Long-acting ß2-agonists + ICS versus leukotriene receptor antagonists + ICS, Outcome 11 Symptom free days: $\%$ change from baseline. . . . . . . . . . . . . . . . . . . . . . . .

Analysis 1.12. Comparison 1 Long-acting B2-agonists + ICS versus leukotriene receptor antagonists + ICS, Outcome 12 Day-time symptom scores (high is worse) - change from baseline. . . . . . . . . . . . . . . . .

Analysis 1.13. Comparison 1 Long-acting ß2-agonists + ICS versus leukotriene receptor antagonists + ICS, Outcome 13 Morning symptoms - change from baseline.

Analysis 1.14. Comparison 1 Long-acting B2-agonists + ICS versus leukotriene receptor antagonists + ICS, Outcome 14 Night-time symptom score (5pt scale, higher score is worse) - change from baseline.

Analysis 1.15. Comparison 1 Long-acting ß2-agonists + ICS versus leukotriene receptor antagonists + ICS, Outcome 15 Change in number of night awakenings per week - change from baseline. . . . . . . . . . . . . . . . . .

Analysis 1.16. Comparison 1 Long-acting $ß 2$-agonists + ICS versus leukotriene receptor antagonists + ICS, Outcome 16 Change in $\%$ of nights with no awakenings per week - change from baseline. 
Analysis 1.17. Comparison 1 Long-acting ß2-agonists + ICS versus leukotriene receptor antagonists + ICS, Outcome 17 Rescue-free nights (\%) - change from baseline.

Analysis 1.18. Comparison 1 Long-acting ß2-agonists + ICS versus leukotriene receptor antagonists + ICS, Outcome 18 Withdrawals for any reason. . . . . . . . . . . . . . . . . . . . . . . . . . . . . .

Analysis 1.19. Comparison 1 Long-acting ß2-agonists + ICS versus leukotriene receptor antagonists + ICS, Outcome 19 Withdrawals due to adverse events.

Analysis 1.20. Comparison 1 Long-acting ß2-agonists + ICS versus leukotriene receptor antagonists + ICS, Outcome 20 Withdrawals due to poor asthma control/asthma exacerbation. . . . . . . . . . . . . . . . . .

Analysis 1.21. Comparison 1 Long-acting B2-agonists + ICS versus leukotriene receptor antagonists + ICS, Outcome 21 Patients with one or more exacerbations requiring hospital admission.

Analysis 1.22. Comparison 1 Long-acting ß2-agonists + ICS versus leukotriene receptor antagonists + ICS, Outcome 22 Serious Adverse events.

Analysis 1.23. Comparison 1 Long-acting B2-agonists + ICS versus leukotriene receptor antagonists + ICS, Outcome 23 Death.

Analysis 1.24. Comparison 1 Long-acting ß2-agonists + ICS versus leukotriene receptor antagonists + ICS, Outcome 24 Headache.

Analysis 1.25. Comparison 1 Long-acting B2-agonists + ICS versus leukotriene receptor antagonists + ICS, Outcome 25 Cardiovascular events.

Analysis 1.26. Comparison 1 Long-acting ß2-agonists + ICS versus leukotriene receptor antagonists + ICS, Outcome 26 Oral moniliasis.

Analysis 1.27. Comparison 1 Long-acting B2-agonists + ICS versus leukotriene receptor antagonists + ICS, Outcome 27 Osteopenia/osteoporosis.

Analysis 1.28. Comparison 1 Long-acting ß2-agonists + ICS versus leukotriene receptor antagonists + ICS, Outcome 28 Elevated liver enzymes.

Analysis 1.29. Comparison 1 Long-acting B2-agonists + ICS versus leukotriene receptor antagonists + ICS, Outcome 29

Overall adverse events.

Analysis 1.30. Comparison 1 Long-acting ß2-agonists + ICS versus leukotriene receptor antagonists + ICS, Outcome 30 Patient treatment satisfaction.

Analysis 1.31. Comparison 1 Long-acting B2-agonists + ICS versus leukotriene receptor antagonists + ICS, Outcome 31 Change from baseline in serum eosinophils (x 10e9/L).

Analysis 2.1. Comparison 2 Subgroup and sensitivity analyses, Outcome 1 Participants with one or more exacerbations requiring systemic corticosteroids: number of inhaler devices.

Analysis 2.2. Comparison 2 Subgroup and sensitivity analyses, Outcome 2 Participants with one or more exacerbations requiring systemic corticosteroids: dose of ICS.

Analysis 2.3. Comparison 2 Subgroup and sensitivity analyses, Outcome 3 Participants with one or more exacerbations requiring systemic corticosteroids: study duration.

Analysis 2.4. Comparison 2 Subgroup and sensitivity analyses, Outcome 4 Serious adverse effects stratified by number of inhaler devices used for LABA + ICS.

Analysis 3.1. Comparison $3 \mathrm{MD}$ archive from previous review version, Outcome 1 Morning PEF (L/min) - change from baseline.

Analysis 3.2. Comparison $3 \mathrm{MD}$ archive from previous review version, Outcome 2 Evening PEF (L/min) - change from baseline.

Analysis 3.3. Comparison $3 \mathrm{MD}$ archive from previous review version, Outcome 3 FEV1 (L) - change from baseline.

Analysis 3.4. Comparison 3 MD archive from previous review version, Outcome 4 Symptom free days (\%) - change from baseline. . . . . . . . . . . . . . . . . . . . . . . . . . . . . . . . . . . . . 118

ADDITIONAL TABLES . . . . . . . . . . . . . . . . . . . . . . . . . . . . . . . . . . 118

APPENDICES . . . . . . . . . . . . . . . . . . . . . . . . . . . . . . 120

WHAT'S NEW . . . . . . . . . . . . . . . . . . . . . . . . . . . . . . . . . . . . . 120

HISTORY . . . . . . . . . . . . . . . . . . . . . . . . . . . . . . . . . . . . . . . 120

CONTRIBUTIONS OF AUTHORS . . . . . . . . . . . . . . . . . . . . . . . . . . . . . 121

DECLARATIONS OF INTEREST . . . . . . . . . . . . . . . . . . . . . . . . . . . . . . 121

SOURCES OF SUPPORT . . . . . . . . . . . . . . . . . . . . . . . . . . . . . . . . . . . . . . . . . . 121

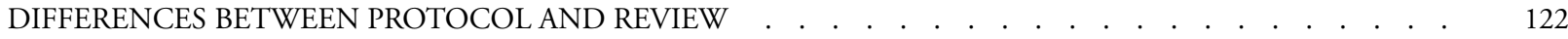

Addition to inhaled corticosteroids of long-acting beta2-agonists versus anti-leukotrienes for chronic asthma (Review) 
Copyright (C) 20II The Cochrane Collaboration. Published by John Wiley \& Sons, Ltd. 


\title{
[Intervention Review]
}

\section{Addition to inhaled corticosteroids of long-acting beta2- agonists versus anti-leukotrienes for chronic asthma}

\author{
Francine M Ducharme ${ }^{1}$, Toby J Lasserson ${ }^{2}$, Christopher J Cates ${ }^{3}$ \\ ${ }^{1}$ Research Centre, CHU Sainte-Justine and the Department of Pediatrics, University of Montreal, Montreal, Canada. ${ }^{2}$ Cochrane \\ Editorial Unit, The Cochrane Collaboration, London, UK. ${ }^{3}$ Population Health Sciences and Education, St George's, University of \\ London, London, UK
}

Contact address: Francine M Ducharme, Research Centre, CHU Sainte-Justine and the Department of Pediatrics, University of Montreal, Room number 7939, 3175 Cote Sainte-Catherine, Montreal, Québec, H3T 1C5, Canada. francine.m.ducharme@umontreal.ca.

Editorial group: Cochrane Airways Group.

Publication status and date: Edited (no change to conclusions), published in Issue 8, 2011.

Review content assessed as up-to-date: 16 March 2010.

Citation: Ducharme FM, Lasserson TJ, Cates CJ. Addition to inhaled corticosteroids of long-acting beta2-agonists versus anti-leukotrienes for chronic asthma. Cochrane Database of Systematic Reviews 2011, Issue 5. Art. No.: CD003137. DOI: 10.1002/14651858.CD003137.pub4.

Copyright (C) 2011 The Cochrane Collaboration. Published by John Wiley \& Sons, Ltd.

\section{A B S T R A C T}

\section{Background}

Asthma patients who continue to experience symptoms despite being on regular inhaled corticosteroids (ICS) represent a management challenge. Long-acting beta 2 -agonists (LABA) or anti-leukotrienes (LTRA) are two treatment options that could be considered as addon therapy to ICS.

\section{Objectives}

We compared the efficacy and safety profile of adding either daily LABA or LTRA in adults and children with asthma who remain symptomatic on ICS.

\section{Search methods}

We searched the Cochrane Airways Group Specialised Register (up to and including March 2010). We consulted reference lists of all included studies and contacted authors and pharmaceutical manufacturers for other published or unpublished studies.

\section{Selection criteria}

We included randomised controlled trials (RCTs) conducted in adults or children with recurrent asthma that was treated with ICS and where a fixed dose of a long-acting beta 2 -agonist or leukotriene agent was added for a minimum of 28 days.

Data collection and analysis

Two authors independently assessed the risk of bias of included studies and extracted data. We sought unpublished data and further details of study design, where necessary.

\section{Main results}

We included 17 RCTs (7032 participants), of which 16 recruited adults and adolescents (6850) and one recruited children aged 6 to 17 years (182). Participants demonstrated substantial reversibility to short-acting beta-agonist at baseline. The studies were at a low risk of bias. The risk of exacerbations requiring systemic corticosteroids was lower with the combination of LABA and ICS compared 
with LTRA and ICS, from $11 \%$ to $9 \%$ (RR 0.83 , $95 \%$ CI 0.71 to 0.97 ; six studies, 5571 adults). The number needed to treat (NNT) with LABA compared to LTRA to prevent one exacerbation over 48 weeks was 38 (95\% CI 22 to 244). The choice of LTRA did not significantly affect the results. The effect appeared stronger in the trials using a single device to administer ICS and LABA compared to those using two devices. In the absence of data from the paediatric trial and the clinical homogeneity of studies, we could not perform subgroup analyses on age or asthma severity. The addition to ICS of LABA compared to LTRA was associated with a statistically greater improvement from baseline in several of the secondary outcomes, including lung function, functional status measures and quality of life. Serious adverse events were more common with LABA than LTRA, although the estimate was imprecise (RR 1.35, 95\% CI 1.00 to 1.82), and the NNT to harm for one additional patient to suffer a serious adverse event on LABA over 48 weeks was 78 (95\% CI 33 to infinity). The risk of withdrawal for any reason in adults was significantly lower with LABA and ICS compared to LTRA and ICS (RR $0.84,95 \%$ CI 0.74 to 0.96 ).

\section{Authors' conclusions}

In adults with asthma that is inadequately controlled on low doses of inhaled steroids and showing significant reversibility with beta 2 agonists, LABA is superior to LTRA in reducing oral steroid treated exacerbations. Differences favouring LABA in lung function, functional status and quality of life scores are generally modest. There is some evidence of increased risk of SAEs with LABA. The findings support the use of a single inhaler for the delivery of LABA and inhaled corticosteroids. We are unable to draw conclusions about which treatment is better as add-on therapy for children.

\section{PLAIN LANGUAGE SUMMARY}

\section{What are the effects of long-acting beta 2 -agonists compared with anti-leukotrienes when added to inhaled steroids?}

People who continue to experience asthma symptoms despite regularly taking inhaled corticosteroids are a challenge for management. It is not clear whether the addition of a long-acting beta 2 -agonist (LABA) such as formoterol or salmeterol would provide more benefit in comparison with an oral anti-leukotriene agent (LTRA), for example zafirlukast or montelukast.

Seventeen trials ( 16 in adults and one in children) were included in this review and were of good quality. We found that the addition of a LABA provides significantly greater protection against exacerbations requiring oral steroids when compared with a LTRA for adults. Based on the results of our analyses, approximately 38 adults (with a range of between 22 and 244) would need to be treated with a LABA rather than a LTRA for 48 weeks to prevent one experiencing an exacerbation needing a course of oral steroids. The trial on children did not contribute data on the main outcome and therefore we could not draw any conclusions for children.

LABAs also led to a greater improvement in lung function, improvement in symptoms, use of rescue medication, quality of life and symptoms compared to the use of LTRAs. The magnitude of the improvements was modest. Serious adverse events were more frequent with LABA than with LTRAs although this result was imprecise. Based on our analyses, around 78 people would need to be treated for 48 weeks with a LABA rather than a LTRA for one of them to experience a serious adverse event. However, due to the lack of precision around our result, the true number could be between 33 and infinity. There are currently insufficient data to draw any conclusions about the effects of these drugs in children.

\section{B A C K G R O U N D}

Leukotrienes are inflammatory molecules and are one of several substances released by mast cells during the immediate response to an inhaled allergen. They are derived from arachidonic acid, the precursor of prostaglandins (Wasserman 1988; Wenzel 1997). There are two families of leukotrienes. Leukotriene $B_{4}$ acts primarily in conditions in which inflammation is dependent on neutrophils, such as cystic fibrosis, inflammatory bowel dis- ease, and psoriasis. The second group $\left(\mathrm{C}_{4}, \mathrm{D}_{4}, \mathrm{E}_{4}\right)$, called cysteinyl-leukotrienes, bind to highly selective receptors to induce eosinophil- and mast cell-induced bronchoconstriction and inflammation associated with asthma (Davis 1997). Drugs that can interfere with the production (leukotriene synthesis inhibitors) and activity (leukotriene receptor antagonists) of leukotrienes have been designed. Leukotriene synthesis inhibitors (for example zileu- 
ton) inhibit the enzyme 5-lipoxygenase thus blocking the production of many leukotrienes (for example $\mathrm{B}_{4}, \mathrm{C}_{4}, \mathrm{D}_{4}$, and $\mathrm{E}_{4}$ ) (Georgitis 1999). Leukotriene (cysteinyl) receptor antagonists (for example montelukast, zafirlukast, pranlukast) block leukotriene $\mathrm{D}_{4}\left(\mathrm{LTD}_{4}\right)$ receptors (Georgitis 1999). Both types of leukotriene modifiers are administered orally as tablets.

Two Cochrane reviews have concluded that leukotriene receptor antagonists (LTRA) are mild anti-inflammatory agents when used as monotherapy (Ducharme 2004b) and bring modest benefit as add-on therapy to inhaled steroids (Ducharme 2004a). Longacting beta $2\left(\beta_{2}\right)$-agonists (LABA) have a similar mode of action to that of short-acting $\beta_{2}$-agonists. Some LABAs may have a slightly slower onset of action than short-acting $\beta_{2}$-agonists (SABA, Lotvall 1996) but display prolonged activation of $\beta_{2}$-receptors (Johnson 1995) in bronchial smooth muscle resulting in prolonged duration of action, for up to 12 hours (Rees 1995). LABA are recommended solely as add-on therapy to inhaled corticosteroids (ICS) in patients with moderate to severe asthma who remain symptomatic despite anti-inflammatory therapy (BTS 2009; GINA; Lougheed 2010). A number of concerns have been raised about the safety of LABA, predominantly when used without concomitant ICS (Cates 2008a; Cates 2008b; Salpeter 2006; Walters 2007). Due to evidence of increased risk of severe exacerbations and death, there has been a recent call for the withdrawal of inhalation devices containing only LABA. The combination of LABA with ICS has been carefully examined and is superior to placebo when introduced as a second-line therapy in adults treated with ICS (Ducharme 2010; Ernst 2006). In children already taking ICS and in steroid-naive patients, there remains some uncertainty as to whether additive LABA confers any meaningful benefit (Ni Chroinin 2009a; Ni Chroinin 2009b). Despite non-statistically significant results for outcomes relating to serious adverse events, the data do not prove conclusively that the risk of serious adverse events is abolished by the presence of ICS (Cates 2009a; Cates 2009b).

People with asthma who continue to experience symptoms with ongoing airway obstruction despite taking regular ICS represent a management challenge. Both leukotriene receptor antagonists (LTRAs) and LABA agents may be considered as add-on therapy to ICS (Adams 2007). There are several reasons to support the synergistic effect of either combination at the cellular or pathophysiology level. LABAs reduce airway hyper-responsiveness by means of functional antagonism (Lipworth 2002) while corticosteroids increase the expression of $\beta_{2}$-adrenergic receptors (Baraniuk 1997), which is a good combination for synergy. LTRAs inhibit the production of cysteinyl leukotrienes, important pro-inflammatory mediators in asthma that are unaffected by steroid treatment. LTRAs are particularly effective in allergen-, exercise-, and aspirin-induced asthma (Krawiec 2002). Thus, both the addition of LTRAs or LABA could potentiate the anti-inflammatory effect of inhaled corticosteroids and lead to better asthma control. The current review compares the relative benefits and safety profile of adding either an LTRA or a LABA to the treatment of patients with asthma who are inadequately controlled by ICS and updates a previous Cochrane review (Ducharme 2006).

\section{O B J E C T I VES}

To compare the safety and efficacy of adding LABA versus LTRA in children and adults with asthma who remain symptomatic in spite of regular treatment with ICS. We specifically wished to examine the relative impact of the two agents on asthma exacerbations, lung function, symptoms, quality of life, adverse health events, and withdrawals.

\section{MET HOD S}

\section{Criteria for considering studies for this review}

\section{Types of studies}

We included randomised controlled trials (RCT) conducted in adults or children in whom a long-acting $\beta_{2}$-agonist (LABA) or leukotriene receptor antagonist (LTRA) were added, as a fixeddose combination, to ICS.

\section{Types of participants}

Children or adults with recurrent or persistent asthma treated with inhaled steroids (ICS) as the only asthma control medication prior to study entry.

\section{Types of interventions}

Interventions included LABA (for example salmeterol or formoterol) or LTRA (for example montelukast, pranlukast, zafirlukast, or zileuton). Participants were required to be on a stable dose of ICS throughout the treatment period. The intervention must have been administered for a minimum of 28 days. Inhaled short-acting $\beta_{2}$-agonists and short courses of oral steroids were permitted as rescue interventions.

\section{Types of outcome measures}

\section{Primary outcomes}

Number of patients with asthma exacerbations requiring a rescue short course of systemic corticosteroids. 


\section{Secondary outcomes}

1. Other measures of severity of exacerbations, such as hospital admissions.

2. Measures reflecting chronic asthma control such as pulmonary function tests; symptom scores; days or nights without symptoms, or both; quality of life; use of rescue fastacting $\beta_{2}$-agonists; and patient satisfaction.

3. Measures of inflammation such as eosinophilia, serum eosinophil cationic protein, and sputum eosinophils.

4. Adverse effects including rates of clinical and biochemical adverse effects.

5. Withdrawal.

\section{Search methods for identification of studies}

\section{Electronic searches}

Trials were identified using the Cochrane Airways Group Specialised Register of trials (searched up to March 2010), which is derived from systematic searches of bibliographic databases including the Cochrane Central Register of Controlled Trials (CENTRAL) (The Cochrane Library), MEDLINE, EMBASE, and CINAHL; and handsearching of respiratory journals and meeting abstracts (please see the Airways Group search methods for further details). All records in the Specialised Register coded as 'asthma' were searched using the following terms:

(((beta* AND agonist*) AND (long-acting OR "long acting")) OR ((beta* AND adrenergic*) AND (long-acting OR “long acting”)) OR (bronchodilat* AND (long-acting OR "long acting")) OR (salmeterol OR formoterol OR eformoterol OR advair OR symbicort)) AND (((steroid* OR glucocorticoid* OR corticosteroid*) AND inhal*) OR (budesonide OR beclomethasone OR fluticasone OR triamcinolone OR flunisolide)) AND (leucotrien* OR leukotrien* OR anti-leukotrien* OR anti-leucotrien* OR *lukast). An additional search of CENTRAL was completed using the above search strategy.

\section{Searching other resources}

We reviewed reference lists of all included studies and reviews to identify potentially relevant citations. We asked authors of included studies and pharmaceutical companies to identify other published or unpublished studies. We searched abstract books of the American Thoracic Society (ATS) and European Respiratory Society (ERS) (1998 to 2005) by hand. For the 2006 and 2010 updates, we accessed a register of study results posted by pharmaceutical manufacturers (www.clinicalstudyresults.org). This website lists study results from the manufacturers of LABAs (GSK, AstraZeneca) and LTRAs (Merck, AstraZeneca).

\section{Data collection and analysis}

\section{Selection of studies}

Two of us screened the title, abstract or descriptors and excluded all studies that were clearly not RCTs or that clearly did not fit the inclusion criteria. Two of us reviewed the full-text documents of the remaining trials, assessing for inclusion based on population, intervention, study design, and outcome. We searched the bibliographies of articles that we retrieved in full to identify any additional studies.

\section{Data extraction and management}

Data for the trials were extracted by two authors and entered into Review Manager 5. Where necessary, expansions of graphic reproductions and estimations from other data presented in the papers were performed.

We contacted primary study authors to confirm methodology and data extraction as well as to provide additional information and clarification, if needed.

\section{Assessment of risk of bias in included studies}

We assessed the risk of bias for each study in terms of allocation generation and concealment, blinding, handling of withdrawals, and selective reporting bias (see Chapter 8 of the Cochrane Handbook) (Higgins 2008). This replaced the previous methodology for assessing study quality (see Differences between protocol and review).

We assessed the risk of bias of each study for the following six items.

1. Allocation generation.

2. Allocation concealment.

3. Blinding.

4. Incomplete data.

5. Selective reporting.

6. Other potential sources of bias.

Our judgments of high, low, and unclear risk of bias were corroborated by quotations from trial reports, correspondence, or summarized information from the relevant sections of the individual study reports.

\section{Assessment of heterogeneity}

We measured heterogeneity of effect sizes between studies with the $\mathrm{I}^{2}$ statistic (Higgins 2003). If heterogeneity was suggested by $\mathrm{I}^{2}>25 \%$, a random-effects model was applied to the summary estimates and was reported in the results.

Subgroup analyses were planned to explore possible effect modifications associated with a priori identified variables or to explore the cause of heterogeneity of study results, if any, for the main 
outcome. Differences in the magnitude of effect attributable to these subgroups were examined with the residual $\mathrm{Chi}^{2}$ test from the odds ratios (Deeks 2001).

\section{Data synthesis}

All included trials were combined using Review Manager 5. For dichotomous variables, we combined data as a pooled fixed-effect model risk ratio (RR) with $95 \%$ confidence interval $(95 \% \mathrm{CI})$. For continuous outcomes we combined data as a pooled fixedeffect model mean difference (MD) or standard mean difference (SMD) with 95\% CI. We calculated the number needed to treat (NNT) for the primary outcome using Visual Rx, a web-based programme available via www.nntonline.net (Cates 2002).

Odds ratios were used for NNT as the results are not affected by the selection of the reference treatment (LABA or LTRA). In view of the different duration of the trials, the pooled odds ratio was applied to the average exacerbation rate in the trials to give NNTs for 12 and 48 weeks of treatment.

\section{Subgroup analysis and investigation of heterogeneity}

1. Number of inhaler devices used to deliver LABA and ICS therapy (added after publication of the protocol, seeDifferences between protocol and review)

2. Dose and type of long-acting $\beta_{2}$-agonist (salmeterol, formoterol)

3. Dose and type of anti-leukotriene (montelukast, pranlukast, zafirlukast, zileuton)

4. Dose and type of ICS (in beclomethasone-equivalents)

5. Children versus adults

6. Baseline severity of airway obstruction based on the per cent predicted forced expiratory volume in one second (FEV1), or peak expiratory flow (PEF): severe $<60 \%$, moderate $61 \%$ to $<$ $80 \%$, mild $\geq 80 \%$ (GINA 2009)

\section{Sensitivity analysis}

For the primary outcome, we planned to perform the following sensitivity analyses to investigate the potential effect of study duration ( $\leq 12$ weeks, $>12$ weeks), publication bias, risk of bias, and funding source (trials funded by producers of LABA, studies funded by producers of LTRA, independently-funded studies) on the study results. Funnel plots were used to test for the presence of publication and other biases for trials contributing data to the main outcomes (Egger 1997).

\section{R E S U L T S}

\section{Description of studies}

See: Characteristics of included studies; Characteristics of excluded studies; Characteristics of ongoing studies.

\section{Results of the search}

See Table 1 for details of the search history which formed the basis of the previous version of the review (all years to January 2006). Three studies from searches conducted between January 2006 and March 2010 met the eligibility criteria of the review (ELEVATE; Lemanske 2010; Pavord 2007). We re-assessed the eligibility of one previously included study and excluded it due to pre-trial exposure to combination therapy (Stelmach 2008). The addition of three new studies and the exclusion of Stelmach 2008 gave a total of 17 included studies reported in 45 publications (see Figure $1)$. 
Figure 1. Literature flow diagram for studies included in 2010 update of the Cochrane review.

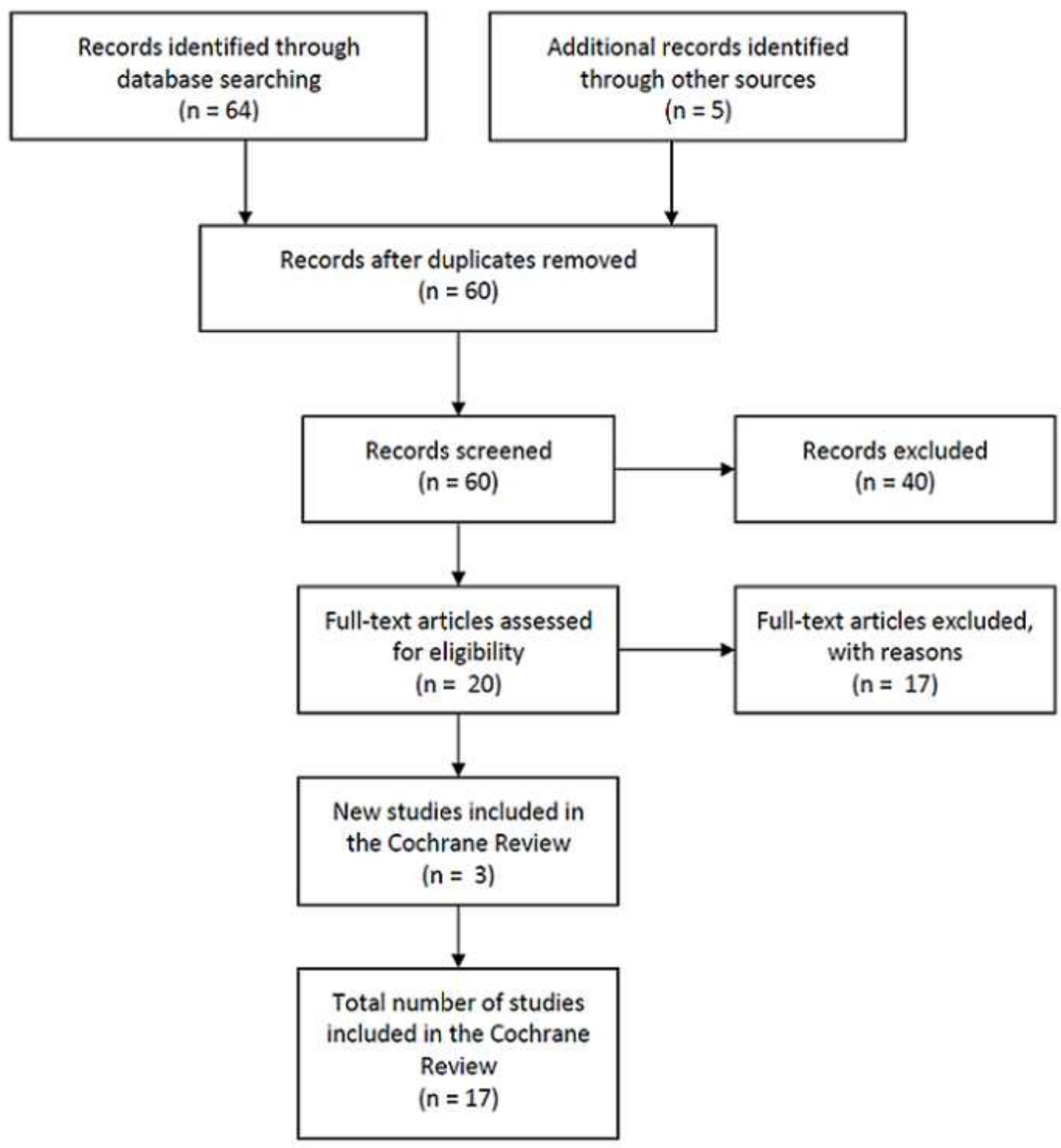




\section{Included studies}

The studies were reported as 13 full-text journal publications (Bjermer 2003; Ceylan 2004; ELEVATE; Fish 2001; Green 2006; Grosclaude 2003; Ilowite 2004; Lemanske 2010; Nelson 2000; Nelson 2001; Pavord 2007; Ringdal 2003; Storms 2004), two unpublished full-text company reports (SAM40030; SD-004-0216) and two conference abstracts (Hendeles 2004; Nsouli 2001). The conference abstracts did not provide data in sufficient detail to contribute to the meta-analyses, and we have not been able to obtain data from the investigators through correspondence. We describe below the characteristics of the 15 included studies which contributed data to the review.

\section{Design}

All but one trial employed a parallel-group design. Lemanske 2010 was a three-arm cross-over trial conducted in children. The authors declined our request for additional data to enable inclusion of any data from this study in the review.

\section{Participants}

Fourteen trials focused on adults, with mean ages ranging from 35 to 44 years, with similar gender representation and mean asthma duration ranging from 10 to 26 years. One study recruited children aged between six and 17 years (Lemanske 2010). Most trials (Bjermer 2003; Ceylan 2004; Fish 2001; Grosclaude 2003; Ilowite 2004; Nelson 2000; Ringdal 2003; Storms 2004) allowed the inclusion of adolescents aged $\geq 15$ years (or $\geq 12$ years for SD-004-0216 and Nelson 2001) although the number of teenagers randomised, if any, was not reported. All but one trial clearly specified that participants could not be steroid naive at enrolment; the remaining study, which failed to specify whether this was a specific criterion for eligibility (Nelson 2001), was still included.

Participants were symptomatic at enrolment despite inhaled steroids at doses of 200 to $1000 \mu \mathrm{g} /$ day of chlorofluorocarbon (CFC)-propelled beclomethasone or equivalent (CFC-BDP), when ICS doses were reported. Severity of asthma as measured by degree of airway obstruction was available for one study. Based on categorisations outlined by GINA of: mild obstruction, FEV1 $80 \%$ predicted or higher; moderate, FEV1 $60 \%$ to $80 \%$ predicted; severe, less than $60 \%$ predicted, the mean FEV1 indicated that participants had mild airway obstruction in two trials (Lemanske 2010; Storms 2004) and moderate airway obstruction in 11 trials (Bjermer 2003; Ceylan 2004; Fish 2001; Green 2006; Ilowite 2004; Nelson 2000; Nelson 2001; Pavord 2007; Ringdal 2003;
SAM40030; SD-004-0216). We were not able to ascertain baseline FEV1 for two studies (ELEVATE; Grosclaude 2003).

Allergy status was reported in two studies (Bjermer 2003; Lemanske 2010) where $65 \%$ and $77 \%$ respectively of participants were affected at baseline. Three studies (Bjermer 2003; Ceylan 2004; Grosclaude 2003) reported that $60 \%, 65 \%$, and $51 \%$ respectively of participants suffered from allergic rhinitis.

Withdrawal rates varied from $8 \%$ to $17 \%$ in the LTRA group and $5 \%$ to $27 \%$ in the LABA group.

\section{Intervention}

During the intervention period, all participants remained on a stable dose of inhaled corticosteroids (ICS). For the purposes of this review, we considered low ICS doses to be $400 \mu \mathrm{g} / \mathrm{day}$ or less (CFC-BDP equivalent), moderate doses to be 400 to $800 \mu \mathrm{g} /$ day (CFC-BDP equivalent) and high doses as $800 \mu \mathrm{g} / \mathrm{day}$ (CFC$\mathrm{BDP}$ equivalent) or higher. Based on these categorisations, most of the studies assessed the addition of LABAs or LTRAs to low and moderate doses of ICS (see Table 2). Two trials failed to report the dose of background ICS (ELEVATE; Nelson 2001).

The LTRAs and doses administered were: zafirlukast $20 \mathrm{mg}$ twice daily (Nelson 2001; SD-004-0216) and montelukast 10 mg once daily (Bjermer 2003; Ceylan 2004; Fish 2001; Green 2006; Grosclaude 2003; Ilowite 2004; Lemanske 2010; Nelson 2000; Pavord 2007; Ringdal 2003; SAM40030; Storms 2004). ELEVATE was a pragmatic study in which study participants were allocated to either montelukast or zafirlukast.

The LABAs used were: salmeterol $50 \mu \mathrm{g}$ twice daily in seven trials (Bjermer 2003; Fish 2001; Grosclaude 2003; Ilowite 2004; Lemanske 2010; Nelson 2000; Nelson 2001; Pavord 2007; Ringdal 2003; SAM40030; Storms 2004) and formoterol $12 \mu \mathrm{g}$ twice daily in three trials (Ceylan 2004; Green 2006; SD-0040216). ELEVATE was a pragmatic study in which study participants were allocated to either formoterol or salmeterol.

In seven studies, the combination therapy (Seretide ${ }^{\circledR}$, Advair ${ }^{\circledR}$ or Symbicort ${ }^{\circledR}$ ) was administered in a single device (Green 2006; Grosclaude 2003; Lemanske 2010; Nelson 2000; Pavord 2007; Ringdal 2003; SAM40030) and by separate inhaler devices in seven studies (Bjermer 2003; Ceylan 2004; Fish 2001; Ilowite 2004; Nelson 2001; SD-004-0216; Storms 2004). We were unable to determine the number of inhalers used to deliver therapy in ELEVATE.

The intervention period varied between four weeks (Nelson 2001; Storms 2004), six weeks (Green 2006), eight weeks (Ceylan 2004; SD-004-0216), 12 weeks (Fish 2001; Grosclaude 2003; Pavord 2007; Nelson 2000; Ringdal 2003; SAM40030), 16 weeks (Lemanske 2010), 48 weeks (Bjermer 2003; Ilowite 2004), and 
two years (ELEVATE).

\section{Outcomes}

The primary outcome (the number of participants with exacerbations requiring rescue systemic corticosteroids) was available for six trials contributing to the main outcome (Bjermer 2003; Fish 2001; Ilowite 2004; Nelson 2000; Nelson 2001; Ringdal 2003), representing $77 \%$ of the total number of participants $(81 \%$ of adults and $0 \%$ children) randomised to trials included in this review. For four trials we could not satisfactorily identify the requirements for oral steroids as binary data (ELEVATE; Green 2006; Grosclaude 2003; Lemanske 2010). None of the studies identified since the first version of the review contributed additional data to our primary outcome.

Other measures of asthma control (for example pulmonary function tests, symptoms, use of rescue $\beta 2$-agonist, quality of life), withdrawals and adverse effects were reported by several included studies.

\section{Excluded studies}

Of the 69 citations retrieved since the 2006 version of the review, we excluded 66 records because:
1. the study was a duplicate (i.e. identical citation of a trial report or a subsequent report of a trial), $\mathrm{N}=29$;

2. the study was not randomised, $\mathrm{N}=2$;

3. the study was ongoing, $\mathrm{N}=5$;

4. the administration of either LTRA or LABA was not standardised across treatment groups, $\mathrm{N}=3$;

5. there was no consistent co-treatment with inhaled glucocorticoids, $\mathrm{N}=8$;

6. one of the tested interventions was not daily LTRA as addon to inhaled glucocorticoids, $\mathrm{N}=9$;

7. one of the tested interventions was not daily LABA as addon to inhaled glucocorticoids, $\mathrm{N}=2$;

8. the tested interventions were administered for less than four weeks, $\mathrm{N}=1$;

9. the study used prohibited co-intervention, $\mathrm{N}=3$;

10. the study did not recruit participants at the step $2^{*}$ level, i.e. the study recruited steroid-naive participants or participants on combination therapy, $\mathrm{N}=3$

* Step 1, 2, and 3 refer to levels of asthma treatment (BTS 2003).

\section{Risk of bias in included studies}

An overview of our judgments for the risk of bias of each study is provided in Figure 2. 
Figure 2. Risk of bias summary: review authors' judgements about each risk of bias item for each included study.

\begin{tabular}{|c|c|c|c|c|c|c|}
\hline & 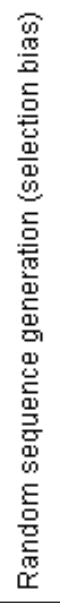 & 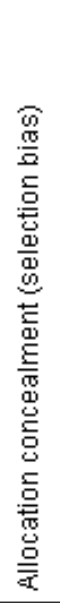 & 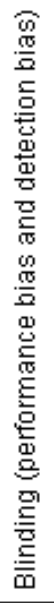 & 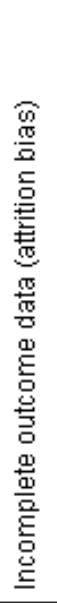 & 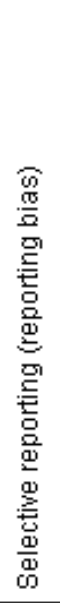 & 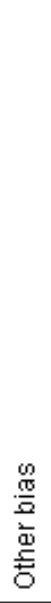 \\
\hline Bjermer 2003 & + & + & + & $?$ & + & + \\
\hline Ceylan 2004 & $?$ & $?$ & - & $?$ & $?$ & $\oplus$ \\
\hline ELEVATE & $?$ & 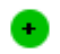 & C & $\odot$ & - & $?$ \\
\hline Fish 2001 & + & + & $\oplus$ & $\oplus$ & + & $\oplus$ \\
\hline Green 2006 & + & + & + & - & + & + \\
\hline Grosclaude 2003 & + & + & - & $?$ & + & + \\
\hline Hendeles 2004 & $?$ & $?$ & $?$ & $?$ & $?$ & $?$ \\
\hline llowite 2004 & + & + & $\oplus$ & $?$ & + & + \\
\hline Lemanske 2010 & + & + & + & $\odot$ & + & + \\
\hline Nelson 2000 & $\oplus$ & + & + & $?$ & + & + \\
\hline Nelson 2001 & + & + & $\odot$ & $?$ & + & + \\
\hline Nsouli 2001 & $?$ & $?$ & $?$ & $?$ & $?$ & $?$ \\
\hline Pavord 2007 & + & + & + & $?$ & + & + \\
\hline Ringdal 2003 & + & + & 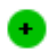 & $?$ & + & + \\
\hline SAM 40030 & + & + & 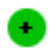 & $?$ & $?$ & + \\
\hline SD-004-0216 & $?$ & + & $\oplus$ & $?$ & $?$ & + \\
\hline Storms 2004 & + & $?$ & $\odot$ & + & + & + \\
\hline
\end{tabular}




\section{Allocation}

Randomisation was clearly described and appropriate in all trials with the exception of three trials that contributed data to the review (Ceylan 2004; Grosclaude 2003; SD-004-0216) and the two abstracts not contributing data in sufficient detail to be metaanalysed (Hendeles 2004; Nsouli 2001). All the data included in the primary outcome were drawn from six studies with robust random sequence generation and allocation concealment.

\section{Blinding}

Twelve trials reported double blinding with identical 'dummy' treatments, while three trials (Ceylan 2004; Grosclaude 2003; Nsouli 2001) had an open-label design. One trial failed to clearly report the means of blinding (Hendeles 2004).

The methodology was confirmed by the authors of all trials contributing data with the exception of three (Ceylan 2004; Grosclaude 2003; Storms 2004). No confirmation was obtained for two studies reported as abstracts (Hendeles 2004; Nsouli 2001).

The six trials contributing data to the primary outcome were double-blind, double-dummy studies.

\section{Incomplete outcome data}

Withdrawal rates were described in all but one study (Nsouli 2001). Withdrawals were not reported in three trials by treatment group (Ceylan 2004; ELEVATE; Lemanske 2010).

The analyses within the studies were frequently described as being by intention to treat. However, further information as to how missing data were handled in the trials was limited. For one trial, data were from patients who completed the study (Nelson 2001).

\section{Selective reporting}

The amount of data for the review primary outcome was high when considered as the proportion of the total participants randomised (77\%). We were unable to use data from other studies due to their broader definition of exacerbations or inadequate reporting of outcome data (ELEVATE; Green 2006; Grosclaude 2003; Lemanske 2010). In one study, exacerbations were not measured (Pavord 2007) and in another there were no occurrences (Storms 2004). From the remaining five studies, we could not ascertain whether exacerbations were measured.

\section{Effects of interventions}

\section{Primary outcome: exacerbations requiring oral (systemic) corticosteroids}

Six trials with 5571 adults (no children) contributed data to the primary outcome (Bjermer 2003; Fish 2001; Ilowite 2004; Nelson 2000; Nelson 2001; Ringdal 2003). The risk of having an exacerbation requiring systemic corticosteroids was statistically significantly lower with the use of LABA and ICS compared to LTRA and ICS (RR 0.83, 95\% CI 0.71 to 0.97) (Figure 3). The addition of LABA lowered the risk of an exacerbation from $11 \%$ to $9 \%$, a $2 \%(95 \%$ CI 0 to $3 \%)$ risk difference in exacerbations requiring systemic steroids over the use of LTRA. The number of patients who needed to be treated (NNT) with the combination of LABA and ICS instead of LTRA and ICS to prevent one exacerbation over 48 weeks was 38 (95\% CI; 22 to 244), as shown in a Cates plot in Figure 4. For the shorter 12-week trials the NNT was 106 (95\% CI 63 to 676$)$. 
Figure 3. Forest plot of comparison: I Leukotriene receptor antagonists + ICS versus Long-acting B2agonists + ICS, outcome: I.I Participants with one or more exacerbations requiring systemic corticosteroids.

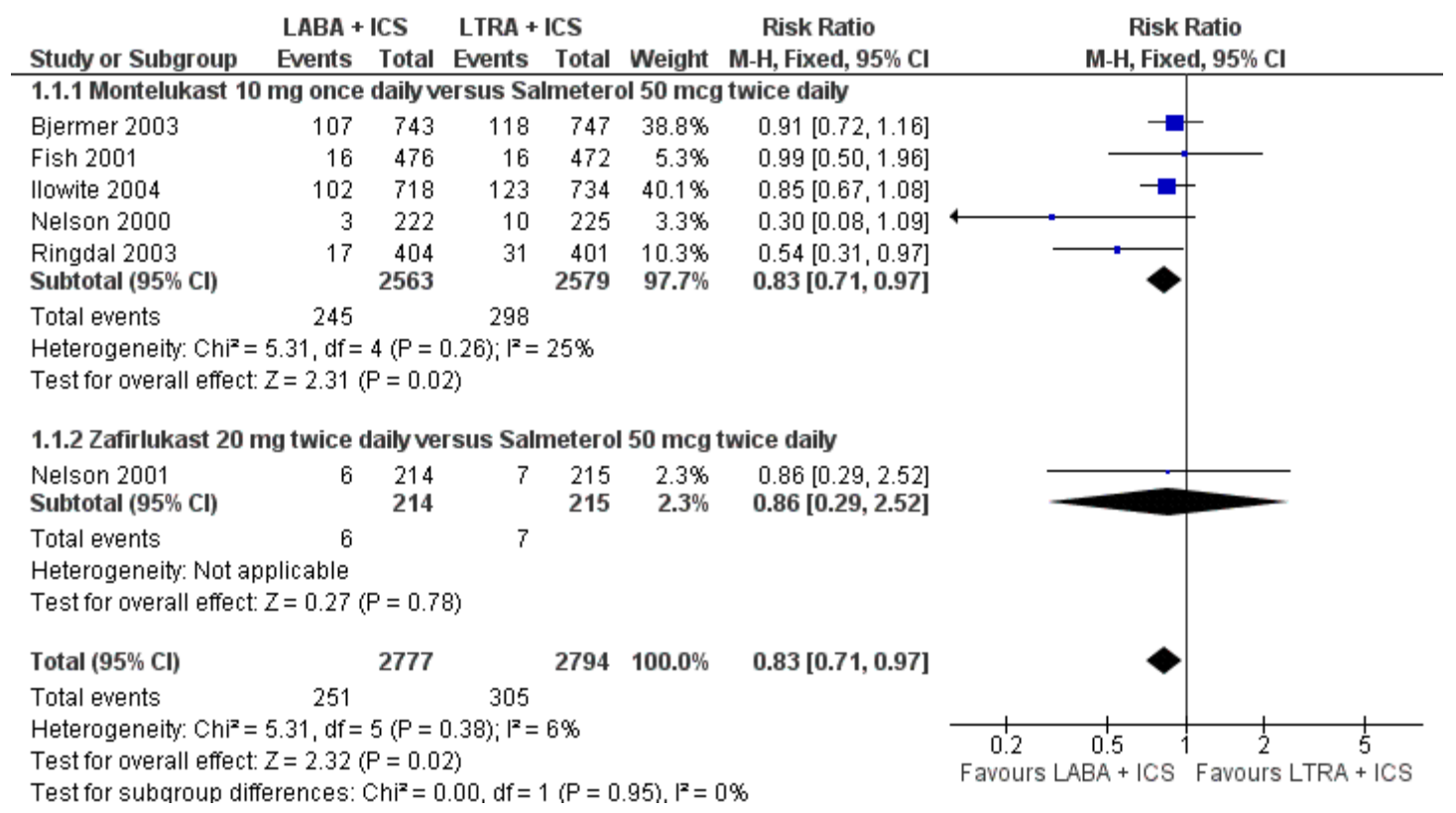


Figure 4. In the LRTA group 16 out of 100 had an exacerbation requiring oral corticosteroids over 48 weeks, compared to $14(95 \% \mathrm{CI} I 2$ to 16$)$ for the LABA group. The NNT with LABA to prevent one patient having an exacerbation over 48 weeks is 38 (95\% Cl 22 to 244$)$.

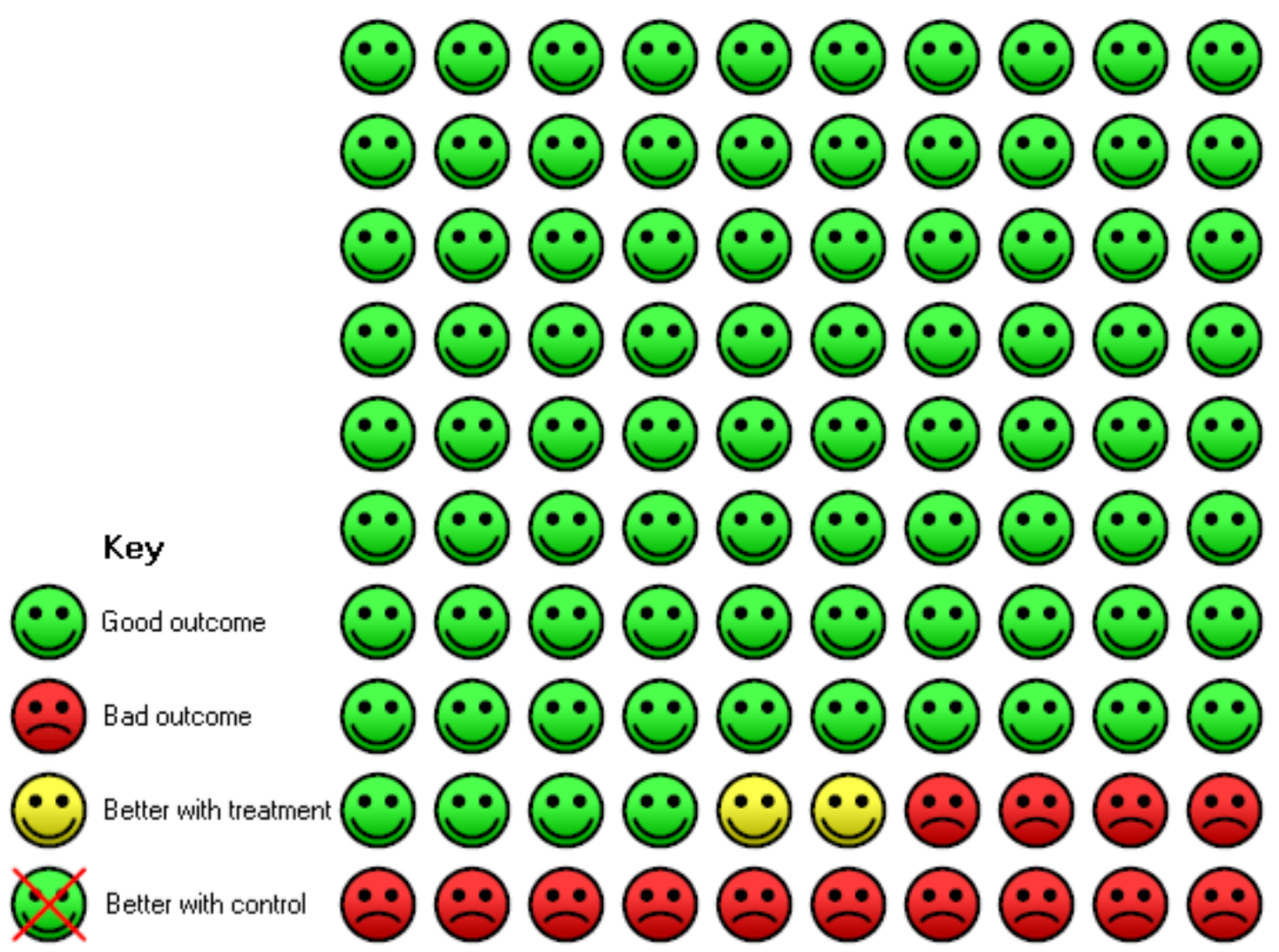

The results were homogeneous despite the different LABAs and LTRAs used $\left(\mathrm{I}^{2}=6 \%\right)$. Although the funnel plot intercept suggested no evidence of publication bias $(-0.01,95 \%$ CI -4.23 to 2.10) visual inspection of the funnel plot precludes firm reassurance (Figure 5). The number of unpublished studies with null results needed to overturn the current findings was nine. 
Figure 5. Funnel plot of comparison: I Leukotriene receptor antagonists + ICS versus Long-acting B2agonists + ICS, outcome: I.I Participants with one or more exacerbations requiring systemic corticosteroids.

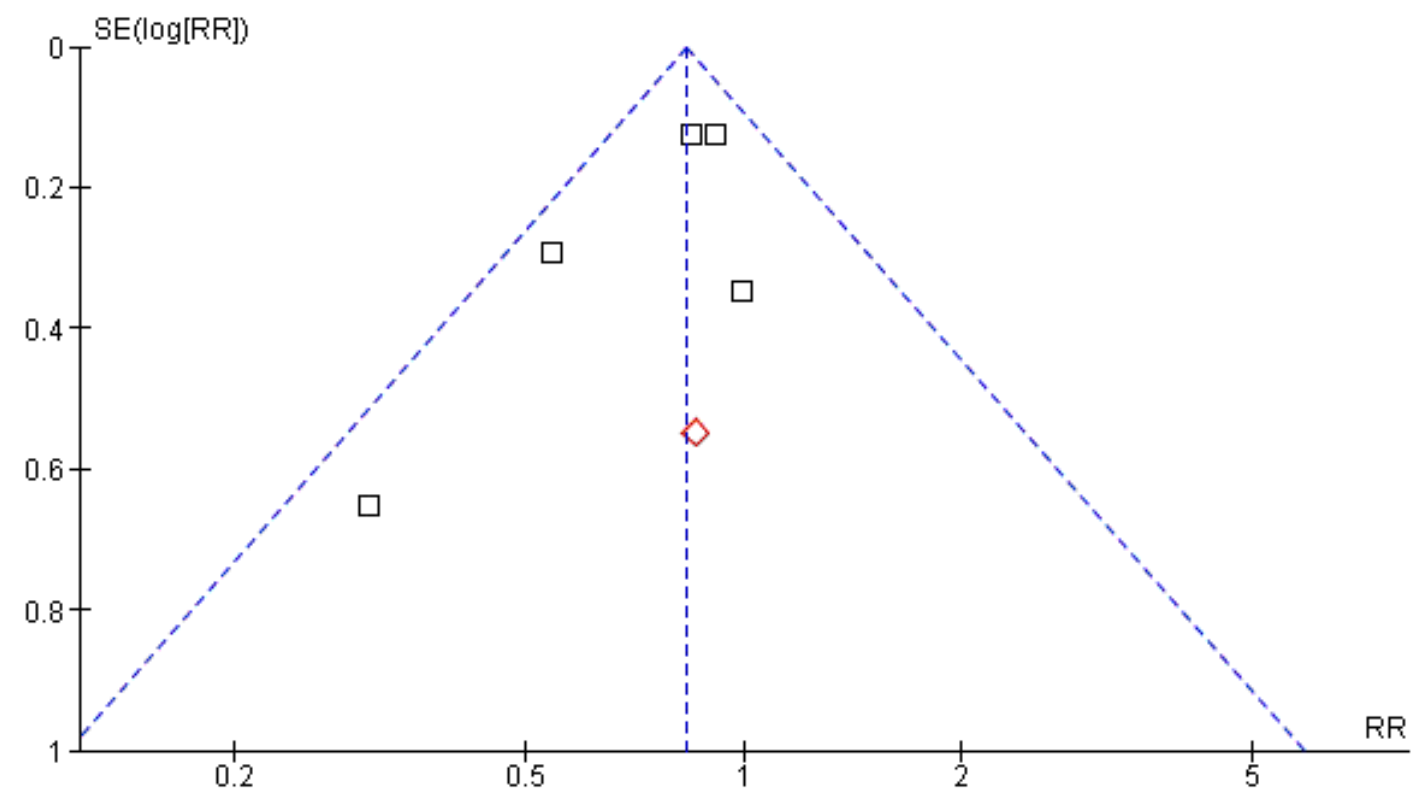

Subgroups

Montelukast $10 \mathrm{mg}$ once daily versus Salmeterol $50 \mathrm{mcg}$ twice daily

Zafirlukast $20 \mathrm{mg}$ twice daily versus Salmeterol $50 \mathrm{mcg}$ twice daily

Although there was no heterogeneity between trials, we had planned a priori to perform subgroup analyses on the following variables, to explore their possible influence on the magnitude of effect (effect modification). The subgroup comparison between single and combined inhalers was added after publication of the initial protocol as a result of work subsequently published on this topic (Nelson 2003).

\section{Number of inhaler devices used to deliver LABA and ICS}

Of the six studies contributing outcome data to the primary outcome, there were two studies (Nelson 2000; Ringdal 2003) where LABA and ICS were delivered in one inhaler device and four studies (Bjermer 2003; Fish 2001; Ilowite 2004; Nelson 2001) where separate inhalers were used. Use of a single inhaler provided significantly greater protection against exacerbations than use of separate inhalers (Analysis 2.1). We calculated the ratio of risk ratios (RRR) as 0.55 (95\% CI 0.31 to $0.95 ; \mathrm{P}=0.04$ ) (Altman 2003). In other words, the protective effect seen with single inhaler devices that combined ICS and LABA on exacerbations requiring rescue oral corticosteroids was almost twice that of the separate inhaler devices as compared to ICA and LTRA. However, this indirect comparison is confounded by other differences between trials, including trial duration and ICS dose.

\section{Dose and type of LABA}

All included studies contributing data towards the meta-analysis used salmeterol as the LABA, preventing assessment of the withinclass effect of LABA.

\section{Dose and type of LTRA}

The type of LTRA used in the included trials did not appear to make a difference on the primary outcome. The RR of exacerbations when LABA + ICS was compared to montelukast + ICS and zafirlukast + ICS was 0.83 (95\% CI 0.71 to 0.97 ) and 0.86 ( $95 \%$ CI 0.29 to 2.52 ) respectively, with no statistical difference between the two subgroups (Analysis 1.1).

\section{Dose and type of inhaled corticosteroids (in beclomethasone-equivalent doses)}

All six studies included in the primary outcome were reported to have used similar doses of inhaled glucocorticoids, ranging from 200 to $282 \mu \mathrm{g} /$ day of HFA-BDP equivalents. There were no subgroup differences between those with low, moderate, mixed, or unclear ICS dose (Analysis 2.2). Fluticasone was used in four trials 
(Bjermer 2003; Ilowite 2004; Nelson 2000; Ringdal 2003). One trial used a variety of ICSs as the authors kept patients on their usual ICS (Fish 2001); and we were unable to obtain details on the ICS used in Nelson 2001.

\section{Children versus adults}

Since the paediatric trial did not contribute any outcome data to this review, the effect on children versus adults could not be examined.

\section{Baseline severity of airway obstruction}

As the studies pertained to patients with moderate airway obstruction who were relatively homogeneous in the average baseline FEV1 (all within $66 \%$ to $76 \%$ of predicted value), subgroup analyses of baseline severity could not be performed.

\section{Duration of trials}

The two trials of 48 week duration showed a smaller difference in treatment effect ((RR $0.88 ; 95 \%$ CI 0.74 to 1.04$)$ than the other trials of 12 week duration or less (RR 0.65 ; 95\% CI 0.45 to 0.96 ), although the confidence intervals were overlapping and the difference between the longer and shorter trials was not statistically significant $\left(\mathrm{Chi}^{2}=1.93, \mathrm{df}=1, \mathrm{P}=0.16\right.$, Analysis 2.3). However, the difference in trial durations could be a confounding factor when considering the subgroup difference between single and separate inhalers.

The studies contributing to the primary outcome were at a low risk of bias, funded by manufacturers of the study drugs, and were all published. The pooled result was not sensitive to bias from any of the sources we assessed and we could not ascertain whether funding source or publication status affected the estimated effect.

\section{Secondary outcomes}

\section{Morning peak expiratory flow (PEF) (L/min change from baseline)}

Eleven studies in 5723 adults contributed data to the morning PEF results. There was a greater improvement in morning PEF with LABA compared with LTRA (15.36 L/min, 95\% CI 11.35 to 19.37) (Analysis 1.2).

\section{Evening PEF (L/min change from baseline)}

Ten studies in 4012 adults contributed data to the meta-analysis of evening PEF. There was a significantly greater improvement in evening PEF with LABA compared with LTRA $(12.64 \mathrm{~L} / \mathrm{min}$, 95\% CI 10.11 to 15.17) (Analysis 1.3).

\section{Forced expiratory volume in one second (FEV1) (L/sec change from baseline)}

Ten studies in 4538 adults contributed data to changes in FEV1. There was a greater improvement in FEV1 with LABA compared with LTRA $(0.08 \mathrm{~L} / \mathrm{sec}, 95 \%$ CI 0.06 to 0.10$)$ (Analysis 1.4).

\section{FEV1 (L/sec, \% change from baseline)}

As only one adult trial contributed date to this outcome (Ceylan 2004), we were unable to pool data (Analysis 1.5).

\section{FEV1 (\% predicted)}

As one small adult study contributed data to this outcome, we were unable to pool data (Analysis 1.6).

\section{FEV1 (\% fall post-exercise)}

One small adult study contributed data to this outcome (Analysis 1.7).

\section{Rescue-free days (\% change from baseline)}

Five studies conducted in 2612 adults contributed data to change in per cent of rescue medication-free days. LABA + ICS showed an increase in the percentage of days with no rescue medication use compared to LTRAs + ICS (MD 9.18, 95\% CI 5.39 to 12.98) (Analysis 1.8).

\section{Rescue medication use (puffs/day)}

Seven studies in 4055 adults contributed data on rescue medication. The combined overall estimate showed a significant decrease in the use of rescue medication with LABA + ICS (MD -0.49 puffs/day, 95\% CI -0.75 to -0.24) (Analysis 1.9).

Change in global asthma quality of life score (higher score is better) - change from baseline

Three studies in 2893 adults reported asthma-specific quality of life using the Juniper's 24-point scale: Bjermer 2003; Ilowite 2004 using montelukast, and Nelson 2001 using zafirlukast. The overall estimate showed an improvement in global asthma quality of life with LABA + ICS that was significantly different to that of LTRA + ICS (MD 0.11, 95\% CI 0.05 to 0.17) (Analysis 1.10).

\section{Symptom-free days (\% change from baseline)}

Six studies with 2692 adults reported symptom-free days (Fish 2001; Grosclaude 2003; Nelson 2000; Nelson 2001; Pavord 2007; Ringdal 2003). The pooled effect estimate showed that the addition of LABA (salmeterol was used in all of these trials) increased 
the percentage of symptom-free days by $7.27 \%$ (95\% CI 4.71 to 9.83) compared with LTRA (Analysis 1.11).

\section{Day-time symptom scores (high score is worse) - change from baseline}

Five studies with 3823 adults reported daytime symptom scores (Fish 2001; Ilowite 2004; Nelson 2000; Nelson 2001; Ringdal 2003). Four of the studies comparing LABA + ICS to montelukast + ICS showed improvement in day-time symptom score with LABA + ICS (SMD -0.18, 95\% CI -0.25 to -0.12) (Analysis 1.12).

\section{Change in morning symptom scores}

As only one adult trial contributed date to this outcome (Ceylan 2004), we were unable to pool data (Analysis 1.13).

\section{Night-time symptom score (5-point scale, higher score is} worse) - change from baseline

As only one trial contributed date to this outcome (Nelson 2001), we were unable to pool data (Analysis 1.14).

Change in number of night awakenings per week - change from baseline

Four studies with 4214 adults reported night awakenings (Bjermer 2003; Fish 2001; Ilowite 2004; Nelson 2000). The combined overall estimate showed that LABA + ICS led to fewer awakenings than LTRA + ICS (MD -0.12, 95\% CI -0.19 to-0.06) (Analysis 1.15).

\section{Change in \% of nights with no awakenings per week - change from baseline}

Two studies reported this outcome based on data from 673 adults (Grosclaude 2003; Nelson 2001) and showed a greater percentage of awakening-free nights per week with LABA + ICS (MD 6.89\%, 95\% CI 2.87 to 10.91 ) (Analysis 1.16).

\section{Change in \% rescue-free nights}

As only one trial contributed date to this outcome (Grosclaude 2003), we were unable to pool data (Analysis 1.17).

\section{Withdrawals for any reason}

Eleven studies involving 6291 adults reported withdrawals due to any reason. Overall, there was a significant reduction in the risk of withdrawal with LABA (12\%) compared with LTRA (14\%) when added to ICS (RR 0.84, 95\% CI 0.74 to 0.96 ) (Analysis 1.18).

\section{Withdrawals due to adverse effects}

Eleven studies in 6291 adults reported withdrawals due to adverse effects. The overall estimate comparing LABA and ICS with LTRA and ICS did not show a significant difference between the groups (RR 1.01, 95\% CI 0.79 to 1.29 ) (Analysis 1.19).

\section{Withdrawals due to poor asthma control (exacerbations)}

Eight studies in 5354 participants reported withdrawals due to exacerbations. There were no significant differences in the overall estimate (RR 0.87, 95\% CI 0.49 to 1.56 ; random-effects model) (Analysis 1.20l).

\section{Patients with one or more exacerbations requiring hospital admission}

Four studies in 3993 adults contributed data for this outcome (Bjermer 2003; Grosclaude 2003; Ilowite 2004; Ringdal 2003). There was no significant difference between the two study groups (RR 1.31, 95\% CI 0.58 to 2.98) (Analysis 1.21).

\section{Serious adverse events}

Seven studies in 5658 adults reported this outcome. The pooled result indicated that serious adverse events were significantly more likely to occur with LABAs (3.4\%) than with LTRAs (2.5\%) (RR $1.35,95 \%$ CI 1.00 to $1.82 ; \mathrm{P}=0.05$ ) (Analysis 1.22). This is shown as a Cates plot in Figure 6, and the number needed to treat to harm (NNTH) for one additional patient to suffer a serious adverse event on LABA over 48 weeks was 78 (95\% CI 33 to infinity). The 12-week NNTH for serious adverse events was 236 (95\% CI 100 to infinity). 
Figure 6. In the LRTA group 4 people out of 100 had a serious adverse event over 48 weeks, compared to 5 $(95 \% \mathrm{Cl} 4$ to 7 ) out of 100 for the LABA group. The NNT(H) for one extra patient to suffer a serious adverse event over 48 weeks with LABA is 78 (95\% Cl 33 to infinity).

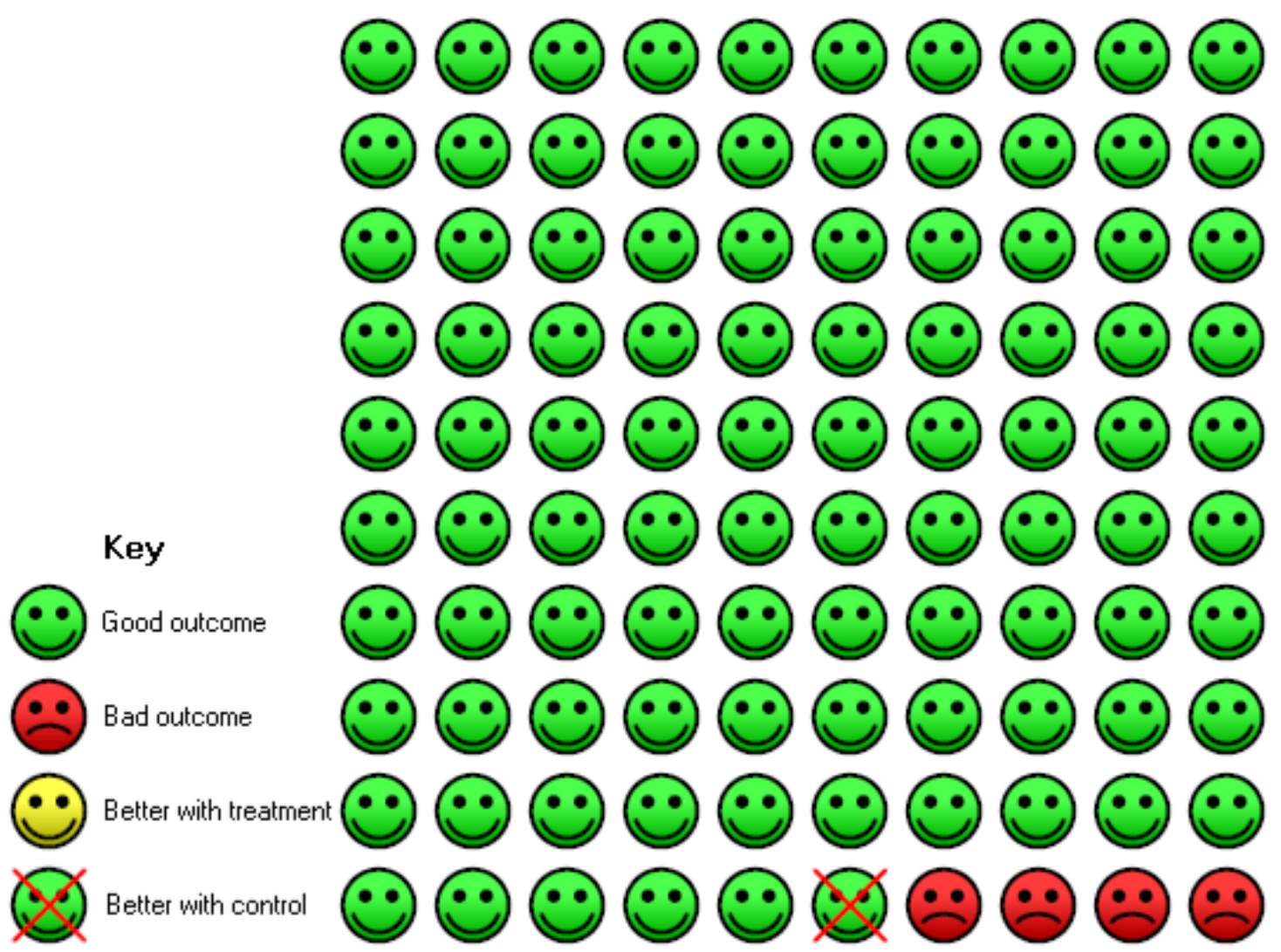

In view of the proposed reasons behind the increased risk of serious adverse events (SAEs) with LABAs (Cates 2008a; Cates 2008b; Cates 2009a; Cates 2009b), we undertook a post hoc subgroup analysis of the pooled estimate by exploring the relationship between the number of inhaler devices and the risk of SAEs. The risk ratio of serious adverse events was RR 0.72 (95\% CI 0.26 to 1.99 ) in the three studies using a single inhaler to deliver both LABA and ICS, compared to LTRA and ICS, and RR 1.43 (95\% CI 1.04 to 1.97 ) in the four studies in which LABA and ICS were delivered by separate inhalers (Analysis 2.4). The difference between the two subgroup estimates did not reach statistical significance, with a test for subgroup differences giving: $\mathrm{Chi}^{2}=1.61, \mathrm{df}=1(\mathrm{P}$ $=0.20) ; \mathrm{I}^{2}=38.1 \%$ (Figure 7).

Deaths

One study reported deaths (Bjermer 2003) with no significant difference between the two study groups (one death occurred in the LABA group) (Analysis 1.23).

\section{Headache}

Ten studies with 6187 adults reported headache as an adverse event. There was no significant difference in the overall result or when the two different types of LTRA were compared to LABA and ICS (RR 1.07, 95\% CI 0.9 to 1.26) (Analysis 1.24).

\section{Cardiovascular events}

Five studies with 5163 adults reported cardiovascular events (Bjermer 2003; Fish 2001; Ilowite 2004; Nelson 2000; Ringdal 2003). There was no significant difference when LABA and ICS was compared to LTRA and ICS (RR 1.09, 95\% CI 0.77 to 1.53 ) (Analysis 1.25).

\section{Oral moniliasis}

Six studies with 5203 adults reported the number of patients with oral moniliasis. The studies compared LABA and ICS to montelukast and ICS, showing an overall significantly increased risk 
of oral moniliasis with the addition of LABA compared to montelukast + ICS (RR 1.86, 95\% CI 1.00 to 3.44) (Analysis 1.26). Yet, the occurrence rates were low and this represents an average risk of oral moniliasis of $1 \%$ for LABA and $0.5 \%$ for LTRA. The risk difference for this outcome was 0.01 ( $95 \%$ CI 0 to 0.01 ).

\section{Osteopenia and osteoporosis}

Two studies on 2963 adults reported this outcome (Bjermer 2003; Ilowite 2004) with no significant difference between the study groups (RR 0.56, 95\% CI 0.12 to 2.63) (Analysis 1.27).

\section{Elevated liver enzymes}

As only one trial contributed data to this outcome (Bjermer 2003), we were unable to pool data (Analysis 1.28).

\section{Overall adverse events}

Nine studies with 5977 adults reported adverse events, which did not show a significant difference when LABA and ICS was compared to LTRA and ICS. In fact, the absence of group difference (RR $1.03,95 \%$ CI 0.99 to 1.07 ) (Analysis 1.29) met our a priori definition of equivalence.

\section{Patient treatment satisfaction}

Three studies with 2020 adults (Fish 2001; Nelson 2001; Ringdal 2003) reported significantly higher patient satisfaction with LABA and ICS than with LTRA and ICS (RR 1.12, 95\% CI 1.04 to 1.20) (Analysis 1.30). Random-effects modelling was used due to the high level of statistical heterogeneity $\left(\mathrm{I}^{2}=61.8 \%\right)$.

\section{Change from baseline in serum eosinophils ( $x$ 10e9/L)}

Two adult studies reported this outcome (Bjermer 2003; Ilowite 2004), which showed a statistically significant greater decrease in serum eosinophils with LTRA + ICS than with LABA + ICS (MD $0.04,95 \%$ CI 0.02 to 0.05 ) (Analysis 1.31 ).

\section{DISCUSSION}

\section{Primary outcome}

Our review has shown that in adult patients who remain symptomatic on low or moderate doses of inhaled steroids, the addition of a LABA reduces the relative risk of exacerbations requiring oral steroids compared to the addition of a LTRA. The rate of exacerbations requiring oral steroids was $11 \%$ in those treated with a combination of LTRA and ICS compared to $9 \%$ with the use of LABA; an absolute risk reduction of $2 \%$. Thirty-eight patients need to be treated over 48 weeks with LABA and ICS instead of LTRA and ICS to avoid one patient from experiencing an exacerbation requiring rescue oral steroids. When assessed over 12 weeks this number is 106 .

The results were homogeneous between the trials. The choice of LTRA did not appear to affect the magnitude of the benefit related to LABA. When compared to LTRA and ICS, a single inhaler containing both LABA and ICS was associated with a $50 \%$ reduction in the risk of exacerbations requiring systemic steroids while a $10 \%$ reduction was observed when the two drugs were delivered separately. This difference were statistically significant but should be interpreted cautiously because it is not based on a headto-head comparison and may be confounded by other differences between the trials that used single or separate inhalers (such as trial duration and ICS dose used). However, the direction of effect is congruent with findings of head-to-head comparisons of single versus separate inhalers (Nelson 2003).

The other characteristics we wished to explore to better guide the selection of treatment for specific patients were similar between the studies, and thus could not be explored. These were age, dose of ICS, degree of airway obstruction, choice of LABA, and study quality. In particular, the absence of paediatric trials contributing data to this outcome prevented any conclusion with regards to the relative effect of LABA versus LTRA as add-on to ICS on the occurrence of exacerbations requiring rescue systemic steroids in children. Treatment duration did not notably affect the direction or magnitude of effect.

\section{Secondary outcomes}

Statistically significant improvements were seen with LABA and ICS compared to LTRA and ICS for most secondary outcomes. The average difference in the improvement from baseline in FEV1 between LABA and LTRA was $80 \mathrm{~mL}$ (95\% CI 60 to $100 \mathrm{~mL}$ ), namely $215 \mathrm{~mL}$ with the addition of LABA to ICS compared to $134 \mathrm{~mL}$ with the addition of LTRA to ICS. A change of $200 \mathrm{~mL}$ or more in FEV1 is considered a clinically important difference as it exceeds normal intra-subject variation (ATS 1991). However, in the absence of a placebo group these changes from baseline may overestimate an expected improvement as both exceed the previously reported benefit for the additive effect of each drug in comparison with the use of ICS alone. Indeed, previous Cochrane reviews have quantified the magnitude of improvement in FEV1 attributable to each drug over that of ICS and placebo. The addition of LABA to ICS was associated with an increase of 110 to 120 $\mathrm{mL}$ (Ducharme 2010), while an increase of $60 \mathrm{~mL}$ was observed for the combination of LTRA and ICS over ICS alone (Ducharme 2004b). The clinical importance of the observed differences in favour of LABA over LTRA ( $80 \mathrm{~mL}$ in FEV1, $15 \mathrm{~mL}$ in morning PEF, and $12 \mathrm{~mL}$ in evening PEF) is debatable, particularly as LABA are specifically meant to achieve bronchodilation. 
The outcome measures of rescue-free days, rescue medication use, asthma quality of life, symptom-free days, daytime symptom score, number and per cent of night awakenings, and patient satisfaction were also statistically significantly better with LABA. Moreover, significantly fewer patients allocated to the combination of LABA and ICS withdrew from the study for any reason. Yet, in most secondary outcomes (other than lung function) the magnitude of the observed difference appeared modest. No group difference was observed in the risk of withdrawals due to poor asthma control and hospitalisation.

Only two trials examined the impact of both strategies on inflammatory markers, namely serum eosinophils. The addition of a LTRA to ICS was associated with a greater (4\%) reduction from baseline serum eosinophils when compared to LABA and ICS.

The risk of serious adverse events (SAEs) was higher with LABA than LTRA $(3.4 \%$ with LABA versus $2.5 \%$ with LTRA, a risk difference of $1 \%$ ) but at the limit of statistical significance since the lower limit of the $95 \%$ CI equalled the conventional threshold for statistical significance at the $5 \%$ level. The apparent increased risk of SAEs with LABA should be regarded as a provisional result. Although the number needed to treat with LABA over 48 weeks for one additional serious adverse event is 78 (95\% CI 33 to infinity), the severity of the adverse effects raises concern. We thus performed a post-hoc analysis to explore whether the use of one or two devices for delivering LABA and ICS influenced the risk of severe adverse outcomes. The increased risk may be limited to the studies using two separate inhalers to deliver LABA and ICS. This is concordant with accumulating evidence of an increased risk of SAEs in patients using LABA without ICS and is possibly mediated by non-compliance with concurrent inhaled steroids (Perera 2003). The test for a difference in risk between single and separate inhalers did not show a significant difference between these subgroups (Figure 7).

There was no difference observed between treatments in the risk of cardiovascular events, headaches, and osteopenia or osteoporosis. Only the risk of oral moniliasis was significantly higher in the LABA group than the LTRA group, although the risk difference was clinically small (1\% for LABA in comparison with $0.5 \%$ for LTRA). The risk of overall adverse effects was similar in both groups, meeting our a priori definition of equivalence and suggesting a similar overall safety profile of the two treatment options. There was no difference between LABA and LTRA in withdrawals due to adverse effects.

One of the entry criteria common to all included trials was the need to demonstrate significant reversibility in FEV1 $(\geq 12 \%$ improvement post-bronchodilation). It is possible that the requirement to demonstrate a significant reversibility with short-acting $\beta_{2}$-agonists resulted in the selection of patients who were more likely to show a response on lung function outcomes. This may explain the greater differences in favour of LABA that were observed with measures of lung function compared to other outcomes. Although reversibility to a bronchodilator is one of the standard di- agnostic criteria of asthma (Boulet 2001; BTS 2003; GINA 2009; USA 2002) only a minority of asthmatic patients display signifcant reversibility at a given point in time (Storms 2003). It is quite possible that the selection of patients, with significant reversibility, has favoured the combination of LABA and ICS over LTRA and ICS.

The major limitation of the relevant studies in this area is the striking absence of large studies examining the best step three in children. There remains uncertainty as to whether LABAs are effective in reducing the requirement for oral steroids in children $(\mathrm{Ni}$ Chroinin 2009b) and a direct comparison of the role of these two drugs in children is urgently required. One well-designed crossover paediatric trial met the eligibility criteria for inclusion in this review (Lemanske 2010). Unfortunately it reported rescue oral steroids in the context of a composite outcome which did not fit our outcome definition and the authors declined to provide the necessary additional data to allow inclusion of other outcomes in this review. Several other paediatric trials were excluded as they tested add-on therapy in children still on step one or in those already on step three (Stelmach 2007; Stelmach 2008). As wide variations in the definition of exacerbations have been identified as an important difficulty in comparing data across studies, the extraction of data restricted to the use of rescue oral steroids appeared important. Many asthma guidelines still recommend LABAs as an add-on therapy in children. In view of the potential harms associated with LABAs, it is particularly critical for future paediatric studies to carefully examine the best option as add-on therapy for those who remain partially controlled on ICS alone.

The relative homogeneity of adult trials limits the application of the results in children and patients older than 65 years old, smokers, and those with asthma with no significant reversibility to shortacting beta 2 -agonists. Moreover, how well these add-on therapies perform when added to doses of ICS outside the range of those we have reviewed remains uncertain. Inadequate documentation and reporting also limits generalisation of results to adolescents. We recommend that trialists including adolescents specify the number included and perform subgroup analyses on this age group to begin to address this considerable gap in knowledge. An individual data meta-analysis might provide critical information to determine if the presence of allergic rhinitis modifies the observed superiority of LABA over LTRA as add-on therapy to ICS.

With well-documented decreases in adherence over time (Storms 2003), one wonders whether an undocumented lack of compliance affected the results. Was there poor adherence to a twice daily regimen for LABA? With a flat dose-response curve to inhaled steroids (Powell 2003), one may even wonder whether similar improvement observed with LTRA and LABA is derived from enhanced compliance to inhaled steroids per se, as a result of study participation, rather than the selected add-on therapies. Is the greater improvement associated with concomitant rather than separate delivery of LABA and ICS mostly attributable to better lung deposi- 
tion of and interaction between both drugs (Buhl 2003; Rosenhall 2003) or better adherence with ICS? In the absence of adherence measures, these questions remain unanswered. The perception of more rapid and greater benefit by the patients with LABA is often regarded by clinicians as justification for selecting LABA over LTRA as add-on therapy. In the two trials reporting satisfaction, significantly more patients were satisfied in the group receiving LABA + ICS (85\%) than those treated with LTRA + ICS (76\%). Although derived from close to 6000 patients in six trials, the results of the primary outcome could be reversed by nine additional trials of similar size to those included, showing no group difference. The direction of results may be influenced by patient selection. It is possible that a differential effect of add-on options may be influenced by age, airway reversibility, smoking status, severity of baseline airway obstruction, type of asthma (eosinophilic versus non-eosinophilic), triggers (such as allergic rhinitis), adherence, etc. Future studies should now focus on comparing these add-on strategies in selected groups of patients so that characteristics of responders to either option may be better delineated. Measures of adherence (before and after randomisation) should also be incorporated in to the design of future studies.

The results apply predominantly to adult asthmatics who remain symptomatic despite 200 to $1000 \mu \mathrm{g} /$ day doses of CFC-BDP or equivalent, and who present with a moderate (baseline FEV1 of $65 \%$ to $75 \%$ predicted value) reversible airway obstruction. The results should not be regarded as applicable to children and adolescents, or patients over 65 years of age.

The extensive search strategy yielded the identification and voluntary disclosure of data from several relevant trials, including two high-quality unpublished reports, and reduced the risk of publication bias. This assessment is also supported by a negative test for funnel plot asymmetry, although one must acknowledge the low sensitivity of this test in the presence of few trials. The high methodological quality of all trials contributing data and the confirmation of methodology and extracted data by authors or the study sponsors for the studies contributing to the primary outcome strengthen our findings.

\section{A U THORS' CONCLUSIONS Implications for practice}

In asthmatic adults with mild or moderate airway obstruction who are on low doses of inhaled corticosteroids and who demonstrate significant reversibility to a short-acting bronchodilator, the risk of an exacerbation requiring oral corticosteroids over 12 to 48 weeks was $17 \%$ lower in participants treated LABA compared LTRA. This was compatible with a NNT over a 48 week period of 38. Compared to LTRAs, the addition of LABA to inhaled corticosteroids is associated with statistically significant improvements in lung function, symptom-free days, use of rescue $\beta_{2}$-agonists, symptoms, symptom-free days, night awakenings, and quality of life, although the group differences are generally modest. There is evidence that LABAs increase the risk of serious adverse events when compared with LTRAs, from $2.5 \%$ to $3.4 \%$. The findings support the use of a single inhaler for the delivery of LABA and inhaled corticosteroids. There are insufficient data to conclude which is the best add-on therapy for children unsatisfactorily controlled on ICS alone.

\section{Implications for research}

Future trials should address the main gaps in knowledge, namely the generalisability of results to the following.

1. Children, adolescents, and elderly patients.

2. Patients with severe (or milder) airway obstruction.

3. Asthmatic patients with minimal or no $(<12 \%)$ airway reversibility to bronchodilators at time of enrolment but with positive provocation challenge or other convincing criteria of the diagnosis of asthma.

4. Patients with co-morbidities, such as allergic rhinitis, aspirin-induced asthma, smokers or having environmental exposure to cigarette smoke, etc.

5. Add-on therapy to higher dose of inhaled corticosteroids than 200 to $280 \mu \mathrm{g} /$ day of HFA-BDP, or equivalent.

6. Monitoring of adherence to both combination therapies.

7. Use of single inhalers for delivery of LABA and ICS compared to LTRA and ICS

8. Comparison of LABA and LTRA versus LABA and ICS (in a single device).

9. Measuring and reporting the impact of each adjunct therapy on inflammatory markers (preferably using induced sputum) and airway hyper-responsiveness over time.

10. Careful monitoring and reporting of outcomes that are important to the patient, particularly exacerbations requiring systemic steroids or hospital admission, symptoms, symptomfree days, night awakenings, quality of life, satisfaction, and lifethreatening asthma as defined by admission to ICU or requiring intubation or ventilation.

\section{ACKNOWLEDGEMENTS}

We are indebted to Liz Arnold, Susan Hansen and Veronica Stewart from the Cochrane Airways Review Group editorial base for extensive ongoing support with identifying, retrieving and translating literature.

We acknowledge the contribution of Felix Ram to the first iteration of this review. We are indebted to the following individuals 
who replied to our request for confirmation of methodology and data extraction, and graciously provided additional data whenever possible: Karen Richardson and Inge Vestbo from GlaxoSmithKline, UK; Ian Naya from AstraZeneca, Sweden; Nitesh Shah and Graham Debney from AstraZeneca, England; and Peter Polos and Steven Bird from Merck Frosst, USA.

\section{REFERENCE S}

\section{References to studies included in this review}

\section{Bjermer 2003 \{published and unpublished data\}}

Bjermer L, Bisgaard H, Bousquet J, Fabbri LM, Greening A, Haahtela T, et al.Montelukast or salmeterol combined with an inhaled steroid in adult asthma: design and rationale of a randomized, double-blind comparative study (the IMPACT Investigation of Montelukast as a Partner Agent for Complementary Therapy-trial). Respiratory Medicine 2000;94:612-21

* Bjermer L, Bisgaard H, Bousquet J, Fabbri LM, Greening AP, Haahtela T, et al.A one-year double-blind randomised comparative trial of montelukast and fluticasone versus salmeterol and fluticasone in protecting against asthma exacerbation in adults. BMJ 2003;327:891-6.

Bjermer L, Kocevar VS, Zhang Q, Yin DD, Polos PG. Health care resource utilization following addition of montelukast or salmeterol in fluticasone in patients with inadequately controlled asthma (IMPACT trial). European Respiratory Journal 2004;24 Suppl 48:127.

Bousquet J, Gaugris S, Kocevar VS, Zhang Q, Yin DD, Polos PG, et al.Increased risk of asthma attacks and emergency visits among asthma patients with allergic rhinitis: A subgroup analysis of the improving asthma control trial. Clinical and Experimental Allergy 2005;35(6): 723-7.

Polos PG. Montelukast or salmeterol added to fluticasone in uncontrolled asthma: a subgroup analysis of the IMPACT study. The Journal of Allergy and Clinical Immunology 2003; 111 Suppl 2:126.

\section{Ceylan 2004 \{published data only\}}

Ceylan E, Mehmet G, Sahin A. Addition of formoterol or montelukast to low-dose budesonide: An efficacy comparison in short- and long-term asthma control. Respiration 2004;71(6):594-601.

\section{ELEVATE \{published data only\}}

A pragmatic single-blind RCT and health economic evaluation of leukotriene receptor antagonists in primary care at steps two and three of the national asthma guidelines (ELEVATE). http://www.hta.ac.uk/project/1204.asp (accessed 24th September 2010).

Sims E, Freeman D, Kemp L, Musgrave S, Juniper L, Gilbert $\mathrm{R}$, et al.Should guidelines be revised for add on therapy in asthma? A 2 year randomized pragmatic equivalence trail of leukotriene antagonist (LTRAs) and long acting beta agonists (LABAs) with inhaled corticosteroids (ICS) in primary care [Abstract]. European Respiratory Society Annual Congress, Berlin, Germany, October 4-8. 2008: E233.

Sims E, Freeman D, Musgrave D, Kemp L, Ayres J. Do asthma guidelines need rewriting for add-on therapy in asthma - results of a 2 year randomised pragmatic equivalence trial of leukotriene antagonists (LTRAs) and long-acting beta agonists (LABAs) with inhaled corticosteroids (ICS) in primary care [Abstract]. Primary Care Respiratory Journal 2008;17(2):128.

* Wilson E, Price D, Musgrave S, Sims E, Shepstone L, et al.The cost-effectiveness of leukotriene receptor antagonists versus long acting beta- 2 agonists as add-on therapy to inhaled corticosteroids for asthma: a pragmatic trial. Pharmacoeconomics 2010;28(7):597-608.

\section{Fish 2001 \{published and unpublished data\}}

Fish J, Boone R, Emmett A, Yancey S, Knobil K, Rickard K. Salmeterol added to inhaled corticosteroids (ICS) provides greater asthma control compared to montelukast. American Journal of Respiratory and Critical Care Medicine 2000;161 Suppl(3):A203.

* Fish JE, Israel E, Murray JJ, Emmett A, Boone R, Yancey $\mathrm{SW}$, et al.Salmeterol powder provides significantly better benefit than montelukast in asthmatic patients receiving concomitant inhaled corticosteroid therapy. Chest 2001; 120(2):423-30.

Knobil K, Dorinsky P, Yancey S, Emmett A, Rickard K. Salmeterol is superior to montelukast as add-on therapy too inhaled corticosteroids (ICS). European Respiratory Journal 2000;16 Suppl 31:457.

McCarthy TP, Boone R, Yancey S, Rickard K. Salmeterol compared to montelukast as adjunctive therapy to inhaled corticosteroids. Thorax 2000;55 Suppl 3:A63.

Nathan BA, Boone RI, Emmett AH, Knobil K, Yancey SW, Rickard KA. Salmeterol and inhaled corticosteroids provide greater asthma control than montelukast and inhaled corticosteroids. Chest 2000;118 Suppl 4:85.

Green 2006 \{published and unpublished data\}

* Green RH, Brightling CE, McKenna S, Hargadon B, Neale N, Parker D, et al.Comparison of asthma treatment given in addition to inhaled corticosteroids on airway inflammation and responsiveness. European Respiratory Journal 2006;27(6):1144-51.

Green RH, Brightling CE, McKenna S, Hargadon B, Parker D, Pavord ID. A placebo controlled comparison of formoterol, montelukast or higher dose of inhaled 
budesonide in subjects with symptomatic asthma despite treatment with lose dose inhaled budesonide [Abstract]. American Thoracic Society 99th International Conference. 2003:B036, Poster H82.

Green RH, Brightling CE, McKenna S, Hargadon B, Parker D, Wardlaw AJ, et al.A placebo controlled comparison of formoterol montelukast or higher dose of inhaled corticosteroids in subjects with symptomatic asthma despite treatment with low dose inhaled corticosteroids. Thorax 2002;57 Suppl 3:iii3.

Grosclaude 2003 \{published and unpublished data\} * Grosclaude M, Cerruti JL, Delannay B, Herent M, Spilthooren F, Desfougeres JL. The fixed fluticasone/ salmeterol gives better control of asthma than the association of beclomethasone dipropionate-montelukast [L'association fixe fluticasone/salmétérol permet un meilleur contrôle de l'asthme que l'association dipropionate de béclométasone-montelukast]. Allergie et Immunologie 2003; 35(9):356-62.

SFCF4007. Comparison of the efficacy and safety of Seretide and beclomethasone dipropionate plus montelukast in asthma. GlaxoSmithKline Clinical Trials Register (http: ctr.gsk.co.uk) 2005.

Hendeles 2004 \{published data only\}

Hendeles L, Erb TA, Bird S, Hustard CM, Edelman JM. Post-exercise response to albuterol after addition of montelukast or salmeterol to inhaled fluticasone [Abstract]. The Journal of Allergy and Clinical Immunology 2004;113 Suppl(2):34.

Ilowite 2004 \{published and unpublished data\} Ilowite J, Webb R, Friedman B, Kerwin E, Bird SR, Hustad CM, et al.Addition of montelukast or salmeterol to fluticasone for protection against asthma attacks: a randomized, double-blind, multicenter study. Annals of Allergy, Asthma \& Immunology 2004;92(6):641-8.

Lemanske 2010 \{published data only\}

Supplementary appendix. http://content.nejm.org/ 2010 (accessed 16th March 2010).

Lemanske RF, Mauger DT, Sorkness CA, Jackson DJ, Boehmer SJ, Martinez FD. Step-up therapy for children with uncontrolled asthma receiving inhaled corticosteroids. New England Journal of Medicine 2010 [accessed 16th March 2010];10.1056/nejmoa1001278:1-11.

\section{Nelson 2000 \{published and unpublished data\}} Bateman ED, Akveld M, Ho M. Greater responder rate to fluticasone propionate/salmeterol combination over montelukast plus fluticasone in asthma. American Thoracic Society 99th International Conference. 2003:B036, Poster H90.

Kerwin E, Srebro S, Church N, Emmett A, Rickard K, Knobil K. Salmeterol added to low-dose fluticasone propionate (FP) improves pulmonary function and albuterol use more rapidly than adding montelukast. Annals of Allergy, Asthma \& Immunology 2001;86:99.

Leibman C, Pathak D, Bowers B, Dorinsky PM, Pepsin P, Kalberg C, et al.Cost effectiveness analysis of fluticasone propionate/salmeterol combination versus montelukast in the treatment of adults with asthma [Abstract]. Journal of Allergy, Asthma and Immunolgy 2002;109 Suppl 1:Ab No: 549.

Leibman CW, Stanford R, Emmett A, Dorinsky PM, Rickard KA. Cost-effectiveness of fluticasone propionate/ salmeterol combination versus fluticasone + montelukast in the treatment of persistent asthma. American Journal of Respiratory and Critical Care Medicine 2002;165 Suppl(8): B4.

* Nelson HS, Busse WW, Kerwin E, Church N, Emmett A, Rickard K, et al.Fluticasone propionate/salmeterol combination provides more effective asthma control than low dose inhaled corticosteroid plus montelukast. The Journal of Allergy and Clinical Immunology 2000;106: 1088-95.

O'Connor RD, Nelson H, Borker R, Emmett A, Jhingran P, Rickard K, et al.Cost effectiveness of fluticasone propionate plus salmeterol versus fluticasone propionate plus montelukast in the treatment of persistent asthma. Pharmacoeconomics 2004;22(12):815-25.

Nelson 2001 \{published and unpublished data\}

Busse W, Nelson H, Wolfe J, Kalberg C, Yancey SW, Rickard KA. Comparison of inhaled salmeterol and oral zafirlukast in patients with asthma. Journal of Allergy and Clinical Immunology 1999;103(6):1075-80.

Kalberg CJ, Rickard KA. A comparison of salmeterol and zafirlukast in patients with persistent asthma. Thorax 1998; 53 Suppl 4:A17.

* Nelson HS, Nathan RA, Kalberg C, Yancey SW, Rickard KA. Comparison of inhaled salmeterol and oral zafirlukast in asthmatic patients using concomitant inhaled corticosteroids. Medscape General Medicine 2001;3(4):3. Rickard KA, Yancey S, Emmett AH, Kalberg CJ. Salmeterol compared to zafirlukast when added to inhaled corticosteroid therapy in patients with persistent asthma. European Respiratory Society, Madrid, Spain, October 913. 1999:P839.

SAS40018. A multi-center, randomized, doubleblind, double dummy, parallel-group, 12 week active control comparison of salmeterol/fluticasone propionate combination product $(50 / 100 \mathrm{mcg}$ BID) via the DISKUS inhaler with fluticasone propionate $(100 \mathrm{mcg}$ BID) via the DISKUS plus oral montelukast (10mg QD) in adults and adolescents with persistent asthma experiencing symptoms on inhaled corticosteroid therapy. GlaxoSmithKline Clinical Trials Register (http://ctr.gsk.co.uk) 2005. Accessed 7th March 2008.

\section{Nsouli 2001 \{published data only\}}

Nsouli SM, McNutt WJ. The additive effects of montelukast and salmeterol in moderate asthmatics who are uncontrolled on a low dose of inhaled corticosteroids. Annals of Allergy, Asthma \& Immunology 2001;86:81.

Pavord 2007 \{published data only\}

* Pavord I, Woodcock A, Parker D, Rice L. Salmeterol plus fluticasone propionate versus fluticasone propionate plus montelukast: a randomised controlled trial investigating 
the effects on airway inflammation in asthma. Respiratory Research 2007 (accessed 16th March 2010);8(67):1-7. [DOI: 10.1186/1465-9921-8-67]

\section{Ringdal 2003 \{published and unpublished data\}}

Bateman ED, Akveld M, Ho M. Greater responder rate to fluticasone propionate/salmeterol combination over montelukast plus fluticasone in asthma. American Thoracic Society 99th International Conference. 2003:B036, Poster $\mathrm{H} 90$.

Gold M, Jogi R, Mulder PGH, Akveld ML. Salmeterol/ fluticasone propionate combination $50 / 100$ ug bid is more effective than fluticasone propionate $100 \mathrm{ug}$ bid plus montelukast $10 \mathrm{mg}$ once daily in reducing exacerbations. European Respiratory Journal 2001;18 Suppl 33:262. Pieters WR, Wilson KK, Smith HC, Tamminga JJ, Sondhi S. Salmeterol/fluticasone propionate versus fluticasone propionate plus montelukast: a cost-effective comparison for asthma. Treatments in Respiratory Medicine 2005;4(2): 129-38.

Pieters WR, Wilson KK, Smith HCE, Tamminga JJ. Cost-effectiveness of fluticasone propionate/salmeterol combination product and fluticasone propionate/ montelukast in asthma. ATS 97th International Conference, May 18-23, San Francisco. 2001.

* Ringdal N, Eliraz A, Pruzinec R, Weber HH, Mulder PG, Akveld M, et al.The salmeterol/fluticasone combination is more effective than fluticasone plus oral montelukast in asthma. Respiratory Medicine 2003;97(3):234-41. Ringdal N, Weber HH, Eliraz A, Pruzinec P, Akveld MLM, Bateman E. The salmeterol/fluticasone propionate combination 50/100 MCG Bid is more effective than the combination of fluticasone propionate 100 MCG Bid plus montelukast $10 \mathrm{MG}$ once daily. ATS 97th International Conference, May 18-23, San Francisco. 2001.

SAS40015. A multicentre, randomised, double-blind, double-dummy, parallel-group, 12-week, active control comparison of the salmeterol/fluticasone propionate combination product $(50 / 100 \mathrm{mcg}$ strength) bd via the DISKUS/ACCUHALER inhaler with fluticasone propionate (100mcg strength) bd via the DISKUS/ ACCUHALER inhaler plus oral montelukast $10 \mathrm{mg}$ od in adolescents and adults with reversible airways obstruction. www.ctr.gsk.co.uk 2005.

\section{SAM40030 \{published and unpublished data\}}

McCarthy TP, Woodcock AA, Pavord ID, Allen DJ, Parker D, Rice L. A comparison of the anti-inflammatory and clinical effects of salmeterol $25 \mathrm{mcg} /$ fluticasone propionate $50 \mathrm{mcg}$ (SFC 50) with fluticasone propionate (FP) plus montelukast $(\mathrm{M})$ in patients with mild to moderate asthma. American Journal of Respiratory and Critical Care Medicine 2003;167(7):A367.

* SAM40030. A phase IV, multicentre, randomised, doubleblind, single dummy, parallel group study to compare the anti-inflammatory action of Seretide $50 / 100$ bd via MDI with Flixotide $100 \mathrm{mcg}$ bd via MDI plus montelukast $10 \mathrm{mg}$ OD for 12 weeks in adults with mild to moderate asthma who are currently taking inhaled corticosteroids but have a requirement for further therapy. GlaxoSmithKline Clinical Trials Register (http:ctr.gsk.co.uk) 2005.

\section{SD-004-0216 \{unpublished data only\}}

Hultquist C, Domeij W, Kasak V, Laitinen L, O’Neil S. Oxis turbuhaler (formoterol), Accolate (zafirlukast) or placebo as add-on treatment to Pulmicort turbuhaler (budesonide) in asthmatic patients on inhaled steroids. Astra Zeneca Report No: SD-4004CR-0216 2000.

\section{Storms 2004 \{published data only\}}

Storms W, Chervinsky P, Ghannam AF, Bird S, Hustad CM, Edelman JM, et al.A comparison of the effects of oral montelukast and inhaled salmeterol on response to rescue bronchodilation after challenge. Respiratory Medicine 2004; 98(11):1051-62

\section{References to studies excluded from this review}

\section{Adinoff 1998 \{published data only\}}

Adinoff AD, Schwartz HJ, Rickard KA, Yancey SW, Swearingen BE. Salmeterol compared with current therapies in chronic asthma. Journal of Family Practice 1998;47(4): 278-84.

\section{Anon 1999 \{published data only\}}

Anonymous. Leukotriene antagonists: new drugs for asthma. MEREC Bulletin 1999;10(1):1-4.

Anon 2000 \{published data only\}

Anonymous. Montelukast: No current use for asthma. Canadian Family Physician 2000;46:85-99.

\section{Anon 2001 \{published data only\}}

Anonymous. Montelukast: oral alternative to inhaled therapy for persistent asthma. Drugs and Therapy Perspectives 2001;17(4):1-6.

Barnes 1997 \{published data only\}

Barnes NC. Current therapy for asthma: time for a change? . Journal of Pharmacy and Pharmacology 1997;49 Suppl 3: 13-6.

Becker 2000 \{published data only\}

Becker A. Clinical evidence with montelukast in the management of chronic childhood asthma. Drugs 2000;59 Suppl 1:29-34.

Bergmann 2004 \{published data only\}

Bergmann KC, Lindemann L, Braun R, Steinkamp G. Salmeterol/fluticasone propionate (50/250 mug) combination is superior to double dose fluticasone (500 mug) for the treatment of symptomatic moderate asthma: A prospective, double-blind trial. Swiss Medical Weekly 2004; 134(3-4):50-8.

Bleecker 2006 \{published data only\} Bleecker ER, Yancey SW, Baitinger LA, Edwards LD, Klotsman M, Anderson WH, et al.Salmeterol response is not affected by beta2-adrenergic receptor genotype in subjects with persistent asthma. The Journal of Allergy and Clinical Immunology 2006;118(4):809-16.

Borker 2005 \{published data only\} Borker R, Emmett A, Jhingran P, Rickard K, Dorinsky P. Abstract determining economic feasibility of fluticasone 
propionate-salmeterol vs montelukast in the treatment of persistent asthma using a net benefit approach and costeffectiveness acceptability curves. Annals of Allergy, Asthma \& Immunology 2005;95(2):181-9.

Brabson 2002 \{published data only\} Brabson JH, Clifford D, Kerwin E, Raphael G, Pepsin PJ, Edwards LD, et al.Efficacy and safety of low-dose fluticasone propionate compared with zafirlukast in patients with persistent asthma. American Journal of Medicine 2002; 113(1):15-21.

\section{Buchvald 2003 \{published data only\}}

* Buchvald F, Bisgaard H. Comparisons of the complementary effect on exhaled nitric oxide of salmeterol versus montelukast in asthmatic children taking regular inhaled budesonide. Annals of Allergy, Asthma \& Immunology 2003;91(3):309-13.

Buchvald FF, Bisgaard H. Comparison of add-on of leukotriene receptor antagonist versus long-acting beta 2agonist of FeNO in asthmatic children on regular inhaled budesonide. European Respiratory Journal 2002;20 Suppl 38:431.

\section{Caffey 2005 \{published data only\}}

Caffey LF, Raissy HH, Marshik P, Kelly HW. A crossover comparison of fluticasone propionate and montelukast on inflammatory indices in children with asthma. Pediatric Asthma, Allergy \& Immunology 2005;18(3):123-30.

Calhoun 2001 \{published data only\} Calhoun W, Sutton L, Emmett A, Dorinsky P. Asthma control with fluticasone propionate/salmeterol 100/ $50 \mu \mathrm{g}$ Diskus(r) versus montelukast in patients previously receiving short-acting beta2-agonists. The Journal of Allergy and Clinical Immunology 2004;113 Suppl(2):117.

* Calhoun WJ, Nelson HS, Nathan RA, Pepsin PJ, Kalberg C, Emmett A, et al.Comparison of fluticasone propionatesalmeterol combination therapy and montelukast in patients who are symptomatic on short-acting beta(2)-agonists alone. American Journal of Respiratory and Critical Care Medicine 2001;164(5):759-63.

\section{Cash 2001 \{published data only\}}

Cash R, Blonski J. In patients with asthma that is not well controlled with inhaled steroids, does salmeterol (Serevent) or montelukast (Singulair) offer better symptom relief?. Journal of Family Practice 2001;50(9):802.

\section{Chopra 2005 \{published data only\}}

Chopra N, Williams M, Rimmer M, Kahl L, Jenkins M, (SMO30006 and SMO30007 International Study Teams). Salmeterol HFA is as effective as salmeterol CFC in children and adults with persistent asthma. Respiratory Medicine 2005;99 Suppl 1:1.

Chuchalin 2002 \{published data only\}

Chuchalin AG, Ovcharenko SI, Goriachkina LA, Sidorenko IV, Tsoi AN. The safety and efficacy of formoterol (Oxis) turbuhaler plus budesonide (Pulmicort) turbuhaler in mild to moderate asthma: a comparison with budesonide Turbuhaler alone and current non-corticosteroid therapy in
Russia. International Journal of Clinical Practice 2002;56(1): 15-20.

Currie 2002 \{published data only\}

Currie GP. Are there additional anti-inflammatory effects of leukotriene receptor antagonists in persistent asthmatics receiving inhaled steroid alone and combined inhaled steroid/long acting B2-agonists? [N0405110243]. National Research Register 2002

\section{Currie 2003a \{published data only\}} Currie GP, Lee DKC, Haggart K, Bates CE, Lipworth BJ. Effects of montelukast on surrogate inflammatory markers in corticosteroid-treated patients with asthma. American Journal of Respiratory and Critical Care Medicine 2003;167 (9):1232-8.

Currie 2003b \{published data only\} Currie GP, Lee DK, Haggart K, Bates CE, Lipworth BJ. Montelukast confers complimentary non-steroid antiinflammatory activity in asthmatics receiving fluticasone alone and fluticasone/salmeterol combination [Abstract]. Journal of Allergy and Clinical Immunology 2003;111 Suppl 2:146.

\section{Currie 2003c \{published data only\}}

Currie GP, Stenback S, Lipworth B J. Effects of fluticasone versus fluticasone/salmeterol on airway calibre and airway hyperresponsiveness in mild persistent asthma. British Journal of Clinical Pharmacology 2003;56(1):11-7.

\section{Davis 2001 \{published data only\}}

Davis EA, Bowers B, Pepsin P, Kalberg C, Dorinsky P. The impact of fluticasone propionate/salmeterol combination product compared to oral montelukast on asthma related quality of life. ATS 97th International Conference, May 18-23, San Francisco. 2001:B92, Poster 714.

Dekhuijzen 2002 \{published data only\}

Dekhuijzen PN, Koopmans PP. Pharmacokinetic profile of zafirlukast. Clinical Pharmacokinetics 2002;41(2):105-14. [: PMID: 11888331]

\section{Delaronde 2005 \{published data only\}} Delaronde S, Peruccio DL, Bauer BJ. Improving asthma treatment in a managed care population. American Journal of Managed Care 2005;11(6):361-8.

\section{Dempsey 2000 \{published data only\}} Dempsey OJ, Wilson AM, Sims EJ, Mistry C, Lipworth BJ. Additive bronchoprotective and bronchodilator effects with single doses of salmeterol and montelukast in asthmatic patients receiving inhaled corticosteroids. Chest 2000;117: 950-3.

Deykin 2007 \{published data only\} Deykin A, Wechsler ME, Boushey HA, Chinchilli VM, Kunselman SJ, Craig TJ, et al.Combination therapy with a long-acting beta-agonist and a leukotriene antagonist in moderate asthma. American Journal of Respiratory and Critical Care Medicine 2007;175(3):228-34.

Dicpinigaitis 2002 \{published data only\} Dicpinigaitis PV, Dobkin JB, Reichel J. Antitussive effect of the leukotriene receptor antagonist zafirlukast in subjects 
with cough-variant asthma. Journal of Asthma 2002;39(4): 291-7.

Donohue 2001 \{published data only\}

Donohue JF, Ohar JA. New combination therapies for asthma. Current Opinion in Pulmonary Medicine 2001;7(2): 62-8.

Dorinsky 2001 \{published data only\}

Dorinsky PM, Kalberg C, Pepsin P, Emmett A, Rickard K. Greater onset of improvement in clinical efficacy measures with first line use of the fluticasone/salmeterol combination product compared to montelukast. ATS 2001 97th International Conference, May 18-23, San Francisco, CA. 2001:D31.

Dorinsky 2002 \{published data only\}

Dorinsky P, Jones S, Kalberg C, Emmett A, Rickard K. Sustained protection against activity-induced bronchospasm (AIB) during chronic treatment with the fluticasone propionate/salmeterol combination (FSC). American Journal of Respiratory and Critical Care Medicine 2002;165 Suppl 8:A568.

\section{Dorinsky 2002a \{published data only\}} Dorinsky PM, Crim C, Yancey S, Edwards L, Rickard K. First line therapy with fluticasone propionate/salmeterol combination product provides superior asthma control versus montelukast or fluticasone propionate alone. Journal of Allergy, Asthma and Immunolgy 2002;109 Suppl 1: Abstract No: 767.

Dorinsky 2004 \{published data only\}

* Dorinsky PM, Stauffer J, Waitkus-Edwards K, Yancey S, Prillaman BA, Sutton L. "Stepping down" from fluticasone propionate/salmeterol $100 / 50 \mathrm{mcg}$ diskus(r) results in loss of asthma control: lack of effect of ethnic origin. Chest 2004; $126 \operatorname{Suppl}(4): 758$.

Keonig S, Waitkus-Edwards K, Yancey S, Prillman B, Dorinsky P. Loss of asthma control when patients receiving fluticasone propionate/salmeterol 100/50 $\mathrm{ug}$ Diskus are "stepped-down" to fluticasone propionate, salmeterol or montelukast alone [Abstract]. The Journal of Allergy and Clinical Immunology 2004;113 Suppl(2):94.

Dunn 2001 \{published data only\}

Dunn CJ, Goa KL. Zafirlukast - an update of its pharmacology and therapeutic efficacy in asthma. Drugs 2001;61(2):285-315.

\section{Edelman 2000 \{published data only\}}

Edelman JM, Turpin JA, Bronsky EA, Grossman J, Kemp JP, Ghannam AF, et al.Oral montelukast compared with inhaled salmeterol to prevent exercise-induced bronchoconstriction. A randomized, double-blind trial. Exercise Study Group. Annals of Internal Medicine 2000; 132(2):97-104.

Edin 2002 \{published data only\}

Edin HM, Prillaman B, Baitinger LA, House KW, Shah TP. Improved ability to perform strenuous activities after treatment with fluticasone propionate-salmeterol combination. American Journal of Respiratory and Critical Care Medicine 2002;165 Suppl 8:A112.

\section{Eliraz 2001 \{published data only\}}

Eliraz A, Ramirez-Rivera A, Ferranti P, Holzer R, Garcia JM, Turcotte C, et al.Similar efficacy following four weeks treatment of asthmatics with formoterol 12 micrograms b.d. delivered by two different dry powder inhalers: differences in inhaler handling. International Journal of Clinical Practice 2001;55(3):164-70.

\section{Eliraz 2002 \{published data only\}}

Eliraz A, Fritscher CC, Perez CMR, Boonsawat W, Nang AN, Bardin P, et al.Symbicort ${ }^{\circledR}$ (budesonide/formoterol) achieves more rapid control of asthma that fluticasone in patients with mild asthma. American Journal of Respiratory and Critical Care Medicine 2002;165 Suppl 8:A567.

Everden 2002 \{published data only\}

* Everden P, Lloyd A, Hutchinson J, Plumb J. Costeffectiveness of eformoterol Turbohaler versus salmeterol Accuhaler in children with symptomatic asthma. Respiratory Medicine 2002;96(4):250-8.

Gabrijelcic 2004 \{published data only\} Gabrijelcic J, Casas A, Rabinovich RA, Roca J, Barbera JA, Chung KF, et al.Formoterol protects against plateletactivating factor-induced effects in asthma. European Respiratory Journal 2004;23(1):71-5.

Giannini 2002 \{published data only\} Giannini D, Tonelli M, Di Franco A, Bacci E, Conti I, Dente FL, et al.Tolerance to the protective effect of salmeterol + fluticasone combination $(50 / 250 \mu \mathrm{g})$ on allergen challenge in mild untreated asthmatics. American Journal of Respiratory and Critical Care Medicine 2002;165 Suppl(8):A566.

Grzelewska 2003 \{published data only\} Grzelewska-Rzymowska I, Malolepszy J, de Molina M, Sladek K, Zarkovic J, Siergiejko Z. Equivalent asthma control and systemic safety of inhaled budesonide delivered via HFA-134a or CFC propellant in a broad range of doses. Respiratory Medicine 2003;97 Suppl D:10-9.

Gupta 2007 \{published data only\}

Gupta S, Kansal AP, Kishan J. Comparative efficacy of combination of fluticasone and salmeterol; fluticasone, salmeterol and montelukast; fluticasone, salmeterol, and levocetirizine in moderate persistent asthma: a study of 120 patients. Chest 2007;132(4):512a.

Havlucu 2005 \{published data only\}

Havlucu Y, Yilmaz G, Goktan C, Yorgancioglu A. Usefulness of HRCT determining the distal airway inflammation in asthma [Abstract]. European Respiratory Journal 2005;26 Suppl 49:Abstract No. 2072.

Horwitz 1998 \{published data only\}

Horwitz RJ, McGill KA, Busse WM. The role of leukotriene modifiers in the treatment of asthma. American Journal of Respiratory and Critical Care Medicine 1998;157:1363-71.

Houghton 2004 \{published data only\} Houghton CM, Langley SJ, Singh SD, Holden J, Monici Preti AP, Acerbi D, et al.Comparison of bronchoprotective and bronchodilator effects of a single dose of formoterol 
delivered by hydrofluoroalkane and chlorofluorocarbon aerosols and dry powder in a double blind, placebocontrolled, crossover study. British Journal of Clinical Pharmacology 2004;58(4):359-66.

Inouhe 2007 \{published data only\}

Inoue $\mathrm{H}$, Komori M, Matsumoto T, Fukuyama $S$, Matsumura M, Nakano T, et al.Effects of salmeterol in patients with persistent asthma receiving inhaled corticosteroid plus theophylline. Respiration 2007;74(6): 611-6.

Jarvis 1998 \{published data only\}

Jarvis B, Adkins JC. Management of asthma - the potential role of zafirlukast. Disease Management Health Outcomes 1998;4(6):337-53

\section{Jarvis 1999 \{published data only\}}

Jarvis B, Faulds D. Inhaled fluticasone propionate: a review of its therapeutic efficacy at dosages $<$ or $=500 \mathrm{microg} / \mathrm{day}$ in adults and adolescents with mild to moderate asthma. Drugs 1999;57(5):769-803.

Jenkins 2005 \{published data only\}

* Jenkins CR, Thien FCK, Wheatley JR, Reddel HK. Traditional and patient-centred outcomes with three classes of asthma medication. European Respiratory Journal 2005; 26(1):36-44.

Reddel HK, Salome CM, Desai M, Thien FK, Jenkins CR. Change in perception of airway obstruction is associated with change in FEV1 and airway hyper-responsiveness. Respirology 2004;9 Suppl 2:A28.

Jonsson 2004 \{published data only\} Jonsson B, Berggren F, Svensson K, O’Byrne PM. An economic evaluation of combination treatment with budesonide and formoterol in patients with mild-tomoderate persistent asthma. Respiratory Medicine 2004;98 (11):1146-54

Kalberg 1999 \{published data only\} Kalberg CJ, Yancey S, Emmett AH, Rickard K. A comparison of salmeterol versus zafirlukast in patients using inhaled corticosteroids. Journal of Allergy and Clinical Immunology 1999;103(1 pt 2):S229.

Kanniess 2002 \{published data only\} Kanniess F, Richter K, Ohme S, Jorres RA, Magnussen H. Montelukast versus fluticasone: effects on lung function, airway responsiveness and inflammation in moderate asthma. European Respiratory Journal 2002;20(4):853-8.

Kanniess 2002b \{published and unpublished data\} Kanniess F, Richter K, Janicki S, Schleiss MB, Jorres RA, Magnussen H. Dose reduction of inhaled corticosteroids under concomitant medication with montelukast in patients with asthma. European Respiratory Journal 2002;20:1080-7.

Karaman 2007 \{published data only\}

Karaman O, Arli O, Uzuner N, Islekel H, Babayigit A, Olmez D, et al.The effectiveness of asthma therapy alternatives and evaluating the effectivity of asthma therapy by interleukin-13 and interferon gamma levels in children. Allergy and Asthma Proceedings 2007;28(2):204-9.
Kardos 2001 \{published data only\}

Kardos P, Bruggenjurgen B, Martin A, Meyer-Sabellek W, Richter K, Vogelmeier C, et al.The treatment of asthma: A study (TACO asthma control plan) introducing a new adjustable combination-treatment plan. Pneumologie 2001; 55(5):253-7.

\section{Keith 2009 \{published data only\}}

Keith PK, Koch C, Djandji M, Bouchard J, Psaradellis E, Sampalis JS, et al.Montelukast as add-on therapy with inhaled corticosteroids alone or inhaled corticosteroids and long-acting beta-2-agonists in the management of patients diagnosed with asthma and concurrent allergic rhinitis (the RADAR trial). Canadian Respiratory Journal 2009;16 Suppl A: 17-31.

Kemp 1998 \{published data only\}

Kemp JP. Antileukotriene drugs as oral controller therapy for asthma. European Respiratory Review 1998;8(54):190-3.

Knorr 2001 \{published data only\}

Knorr B, Franchi LM, Bisgaard H, Vermeulen JH, LeSouef P, Santanello N, et al.Montelukast, a leukotriene receptor antagonist, for the treatment of persistent asthma in children aged 2 to 5 years. Pediatrics 2001;108(3):E48.

Koenig 2008 \{published data only\}

Koenig SM, Ostrom N, Pearlman D, Waitkus-Edwards $\mathrm{K}$, Yancey S, Prillaman BA, et al.Deterioration in asthma control when subjects receiving fluticasone propionate/ salmeterol 100/50 mcg Diskus are "stepped-down". The Journal of Asthma 2008;45(8):681-7.

Kohrogi 1999 \{published data only\} Kohrogi H, Iwagoe H, Fuji K, Hamamoto J, Fukuda K, Hirata $\mathrm{N}$, et al.The role of cysteinyl leukotrienes in the pathogenesis of asthma: Clinical study of leukotriene antagonist pranlukast for 1 year in moderate and severe asthma. Respirology 1999;4:319-23.

\section{Laviolette 1999 \{published data only\}}

Laviolette M, Malmstrom K, Lu S, Chervinsky P, Pujet JC, Peszek I, et al.Montelukast Added to Inhaled Beclomethasone in Treatment of Asthma. American Journal of Respiratory and Critical Medicine 1999;160:1862-8.

Lazarus 2001 \{published data only\} Lazarus SC, Boushey HA, Fahy JV, Chinchilli VM, Lemanske RF Jr, Sorkness CA, et al.Long-acting beta2agonist monotherapy vs continued therapy with inhaled corticosteroids in patients with persistent asthma: a randomized controlled trial. JAMA 2001;285(20): 2583-93.

Lee 2004 \{published data only\} Lee DK, Haggart K, Currie GP, Bates CE, Lipworth BJ. Effects of hydrofluoroalkane formulations of ciclesonide 400 microg once daily versus fluticasone 250 microg twice daily on methacholine hyper-responsiveness in mild-tomoderate persistent asthma. British Journal of Clinical Pharmacology 2004;58(1):26-33.

Lee DKC, Jackson CM, Bates CE, Lipworth BJ. Cross tolerance to salbutamol occurs independently of beta2 
adrenoceptor genotype-16 in asthmatic patients receiving regular formoterol or salmeterol. Thorax 2004;59(8):662-7.

\section{Lee 2005 \{published data only\}}

* Lee DK, Fardon TC, Bates CE, Haggart K, McFarlane LC, Lipworth BJ. Airway and systemic effects of hydrofluoroalkane formulations of high-dose ciclesonide and fluticasone in moderate persistent asthma. Chest 2005; 127(3):851-60.

Lee DKC, Lipworth BJ. Relative airway and systemic effects of high dose ciclesonide and fluticasone propionate in asthma. Thorax 2004;59 Suppl II:11.

\section{Leflein 2002 \{published data only\}} Leflein JG, Szefler SJ, Murphy KR, Fitzpatrick S, CruzRivera M, Miller CJ, et al.Nebulized budesonide inhalation suspension compared with cromolyn sodium nebulizer solution for asthma in young children: results of a randomized outcomes trial. Pediatrics 2002;109(5):866-72.

\section{Lipworth 2000 \{published data only\}}

Lipworth BJ, Dempsey OJ, Aziz I, Wilson AM. Effects of adding a leukotriene antagonist or a long-acting beta2agonist in asthmatic patients with the glycine- 16 beta2 adrenoceptor genotype. American Journal of Medicine 2000; 109:114-21.

\section{Liu 1996 \{published data only}

Liu MC, Dube LM, Lancaster J, Zileuton Study Group. Acute and chronic effects of a 5-lipoxygenase inhibitor in asthma: A 6-month randomized multicenter trial. The Journal of Allergy and Clinical Immunology 1996;98:859-71.

\section{LOCCS \{published data only\}}

Peters SP, Anthonisen N, Castro M, Holbrook JT, Irvin CG, Smith LJ, et al.Randomized comparison of strategies for reducing treatment in mild persistent asthma. New England Journal of Medicine 2007;356(20):2027-39.

\section{Maspero 2008 \{published data only\}}

Maspero J, Guerra F, Cuevas F, Gutierrez JP, Soto-Ramos M, Anderton S, et al.Efficacy and tolerability of salmeterol/ fluticasone propionate versus montelukast in childhood asthma: A prospective, randomized, double-blind, doubledummy, parallel-group study. Clinical Therapeutics 2008;30 (8):1492-504.

Maspero J, Guerra F, Orozco S, Soto M, GutierrezSchwanhauser J, Mechali DG, et al.The efficacy of inhaled salmeterol/fluticasone propionate diskus/accuhaler compared with oral montelukast in children with persistent asthma PEACE (PEdiatric Asthma Control Evaluation ) [Abstract]. American Thoracic Society International Conference, May 16-21, 2008, Toronto. 2008:A709 [\# K61].

Maspero J, Soto-Ramos M, Guerra F, Chan R, Sharma $\mathrm{R}$, Pedersen S. Improved asthma control and fewer exacerbations with inhaled salmeterol/fluticasone propionate compared with oral montelukast in children with persistent asthma: PEACE (Pediatric Asthma Control Evaluation). Chest 2008;134(4):51001s.
McCarthy 2002 \{published data only\}

McCarthy TP, Grening AP, Holgate SK, Whitehead C, Rice L. Salmeterol/fluticasone propionate combination (SFC) is more effective that beclometasone dipropionate (BDP) in patients not well controlled on bronchodilators alone. American Journal of Respiratory and Critical Care Medicine 2002; Vol. 165 Suppl 8:A566.

Meltzer 2002 \{published data only\}

Meltzer EO, Lockey RF, Friedman BF, Kalberg C, GoodeSellers S, Srebro S, et al.Efficacy and safety of low-dose fluticasone propionate compared with montelukast for maintenance treatment of persistent asthma. Mayo Clinic Proceedings 2002;77(5):437-45.

Miraglia del Giudice 2007 \{published data only\} Miraglia del Giudice M, Piacentini GL, Capasso M, Capristo C, Maiello N, Boner AL, et al.Formoterol, montelukast, and budesonide in asthmatic children: Effect on lung function and exhaled nitric oxide. Respiratory Medicine 2007;101(8):1809-13.

Mitchell 2005 \{published data only\}

Mitchell EA, Didsbury PB, Kruithof N, Robinson E, Milmine M, Barry M, et al.A randomised controlled trial of an asthma clinical pathway for children in general practice. Acta Paediatrica 2005;94(2):226-33.

\section{Molitor 2005 \{published data only\}}

Molitor S, Liefring E, Traytmann M. Asthma control with the salmeterol-fluticasone-combination disc compared to standard treatment. Pneumologie 2005;59(3):167-73.

\section{Naedele-Risha 2001 \{published data only\}} Naedele-Risha R, Dorinsky P, Craig TJ. Dual components of optimal asthma therapy: scientific and clinical rationale for the use of long-acting beta-agonists with inhaled corticosteroids. Journal of the American Osteopathic Association 2001;101(9):526-33.

Nathan 2000 \{published data only\} Nathan RA. Adjunctive therapy for asthma: treatment options. American Journal of Managed Care 2000;6 Suppl: $368-76$.

\section{Nathan 2001b \{published data only\}}

Nathan RA, Kemp JP. Efficacy of antileukotriene agents in asthma management. Annals of Allergy Asthma \& Immunology 2001;86(6 Suppl 1):9-17.

Nathan 2005 \{published data only\} Nathan RA, Philpot E, Faris M, Prillaman B, Yancey S, Dorinsky P. In patients taking fluticasone propionate/ salmeterol 100/50 pg Diskus(r) for asthma, the addition of fluticasone propionate nasal spray 200ug QD to treat concomitant allergic rhinitis has a safety profile comparable to the addition of montelukast 10mg QD or placebo [Abstract]. The Journal of Allergy and Clinical Immunology 2004;113 Suppl 2:202.

* Nathan RA, Yancey SW, Waitkus-Edwards K, Prillaman BA, Stauffer JL, Philpot E. Fluticasone propionate nasal spray is superior to montelukast for allergic rhinitis while neither affects overall asthma control. Chest 2005;128(4): 1910-20. 
Nelson 2004 \{published data only\}

Nelson H, Stauffer J, Yancey S, Prillaman B, Sutton L, Dorinsky P. In patients with both uncontrolled asthma and allergic rhinitis, montelukast added to fluticasone propionate/salmeterol provides no additional clinical improvements in overall asthma control regardless of baseline asthma severity [Abstract]. American Thoracic Society 100th International Conference, May 21-26, 2004, Orlando. 2004:D36, Poster A49.

Nelson HS, Yancey S, Waitkus-Edwards K, Prillaman B, Philpot E, Dorinsky P. In patients taking fluticasone

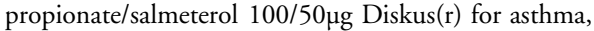

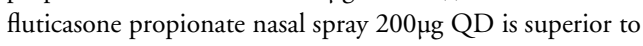
montelukast 10mg QD in the treatment of allergic rhinitis in patients with coexistent allergic rhinitis: implication for the one airway hypothesis [Abstract]. The Journal of Allergy and Clinical Immunology 2004;113 Suppl 2:200.

O'Sullivan 2003 \{published data only\}

* O'Sullivan S, Akveld M, Burke CM, Poulter LW. Effect of the addition of montelukast to inhaled fluticasone propionate on airway inflammation. American Journal of Respiratory and Critical Care Medicine 2003;167(5):745-50.

Ohbayashi 2009 \{published data only\}

Ohbayashi H, Shibata N, Adachi M. The evaluation of the additional effect of pranlukast to salmeterol/fluticasone combination therapy using impulse oscillometry system in a randomized crossover study. American Thoracic Society International Conference, May 15-20, 2009, San Diego. 2009:A2764.

Ohbayashi H, Shibata N, Hirose T, Adachi M. Additional effects of pranlukast in salmeterol/fluticasone combination therapy for the asthmatic distal airway in a randomized crossover study. Pulmonary Pharmacology \& Therapeutics 2009;22(6):574-9.

\section{Ollendorf 2000 \{published data only\}}

Ollendorf DA, Pozniak AS, Bowers BW, Oster G. Economic impact of salmeterol versus leukotriene modifiers in patients with chronic asthma. Chest 2000;118 Suppl(4):185.

Oppenheimer 2008 \{published data only\}

Oppenheimer J, Mosnaim G, Waitkus-Edwards K, Prillaman B, Ortega H. Fluticasone propionate/salmeterol via diskus is superior to montelukast in overall asthma control in subjects with both asthma and allergic rhinitis [Abstract]. Chest 2008;134(4):94002s.

Ortega-Cisneros 1998 \{published data only\}

Orgega-Cisneros M, Maldonado-Alanis ML, RosasVargas MA, Sienra-Monge JJL. Salmeterol and inhaled beclomethasone versus high dose inhaled beclomethasone in the control of pediatric patients with moderate asthma. Annals of Allergy, Asthma \& Immunology 1998;80:131, P124.

Paterson 1999 \{published data only\}

Paterson MC, Wilson AM, Dempsey OJ, Sims EJ, Lipworth $B J$. The effect of combination therapy with salmeterol and montelukast in asthmatic patients receiving inhaled corticosteroids. European Respiratory Society; 1999 Oct 913; Madrid, Spain. 1999:3490.

Pearlman 2002 \{published data only\}

Pearlman DS, White MV, Lieberman AK, Pepsin PJ,

Kalberg C, Emmett A, et al.Fluticasone propionate/ salmeterol combination compared with montelukast for the treatment of persistent asthma. Annals of Allergy, Asthma \& Immunology 2002;88(2):227-35.

Perez 2000 \{published data only\}

Perez O. Treatment with montelukast in children with asthma [Tratamiento con montelukast en el nino con asma]. Revista Alergia Mexico 2000;47(1):30-2.

Peroni 2002 \{published data only\}

Peroni DG, Piacenthi GL, Pietrobelli A, Bodini A, Boner AL. Montelukast or formoterol as second-line therapy in asthmatic children exposed to allergens. The Journal of Allergy and Clinical Immunology 2002;109 Suppl(1):240 (Abs 730).

Peroni 2005 \{published data only\}

Peroni DG, Piacentini GL, Bodini A, Ress M, Costella S, Boner AL. Montelukast versus formoterol as second-line therapy in asthmatic children exposed to relevant allergens. Allergy \& Asthma Proceedings 2005;26(4):283-6.

Petermann 2004 \{published data only\}

Petermann W, Mutschler E. Fixed combination of inhalant steroids and long-acting beta2 agonists, an important option in the treatment of persisting asthma. Deutsche Medizinische Wochenschrift 2004;129(5):210-4.

Plaza 2005 \{published data only\}

Plaza V, Cobos A, Ignacio-Garcia JM, Molina J, Bergonon S, Garcia-Alonso F, et al.Cost-effectiveness of an intervention based on the Global INitiative for Asthma (GINA) recommendations using a computerized clinical decision support system: A physicians randomized trial. Medicina Clinica 2005;124(6):201-6.

Price 2003 \{published data only\}

Price D, Haughney J, Rosen JP, Morrison K. Switching to symbicort(r) from beclomethasone dipropionate (BDP) with or without salmeterol significantly improved symptom severity in patients with moderate asthma. American Thoracic Society 99th International Conference. 2003: D034, Poster C40.

Riccioni 2002 \{published data only\} Riccioni G, D’Orazio N, Di Ilio C, Della Vecchia R, De Lorenzo A. Effectiveness and safety of montelukast versus budesonide at difference doses on bronchial reactivity in subjects with mild-persistent asthma [Efficacia e tollerabilita del montelukast verso budesonide a diverso dosaggio sulla reattivita bronchiale in soggetti con asma di grado lieve-persistente]. Clinica Terapeutica 2002;155(317):321.

Rickard 1998 \{published data only\}

Rickard K, Boone R, Yancey S, Emmett A. Salmeterol provides better improvement in pulmonary function than zafirlukast in patients with persistent asthma. European Respiratory Journal 1998;Suppl 29:19. 
Rosenhall 2003 \{published data only\}

* Rosenhall L, Elvstrand A, Tilling B, Vinge I, Jemsby P, Stahl E, at al. One-year safety and efficacy of budesonide/ formoterol in a single inhaler (Symbicort Turbuhaler) for the treatment of asthma. Respiratory Medicine 2003;97(6): $702-8$.

SAS40036 \{unpublished data only\}

GlaxoSmithKline (SAS40036). A multicenter, randomized, double-blind, double-dummy, parallel group, 16-week comparison of asthma control in adolescents and adults receiving either fluticasone propionate/salmeterol DISKUS combination product $100 / 50 \mathrm{mcg}$ BID, fluticasone propionate DISKUS $100 \mathrm{mcg}$ BID, salmeterol xinafoate DISKUS $50 \mathrm{mcg}$ BID, or oral montelukast $10 \mathrm{mg}$ QD. GlaxoSmithKline Clinical Trial Register 2004:Accessed 7th March 2008.

\section{SAS40037 \{unpublished data only\}}

GlaxoSmithKline (SAS40037). A multicenter, randomized, double-blind, double-dummy, parallel group, 16-week comparison of asthma control in adolescents and adults receiving either fluticasone propionate/salmeterol DISKUS combination product $100 / 50 \mathrm{mcg}$ BID, fluticasone propionate DISKUS $100 \mathrm{mcg}$ BID, salmeterol xinafoate DISKUS 50mcg BID, or oral montelukast 10mg QD. GlaxoSmithKline Clinical Trial Register 2004:Accessed: 7th March 2008.

\section{SAS40066 \{unpublished data only\}}

GlaxoSmithKline (SAS40066). A randomised, openlabel, crossover pilot study, assessing patient preference for ADVAIR DISKUS 100/50 BID (fluticasone propionate/ salmeterol combination product $100 / 50 \mathrm{mcg}$ ) versus Singulair QD (montelukast $10 \mathrm{mg}$ ) in subjects $>=15$ years of age with persistent asthma. GlaxoSmithKline Clinical Trial Register 2004:Accessed 7th March 2008.

Serrier 2003 \{published data only\}

Serrier P, Roche N, Pello JY, Larguier JS, Mezzi K. Asthma control achieved with inhaled corticosteroids and longacting beta2-agonists in a free or fixed combination: Results of the ALISE survey. La Presse Medicale 2003;32(11): 493-7.

\section{Sheth 2002 \{published data only\}}

Sheth K, Borker R, Emmett A, Rickard K, Dorinsky P. Cost-effectiveness comparison of salmeterol/fluticasone propionate versus montelukast in the treatment of adults with persistent asthma. Pharmacoeconomics 2002;20(13): 909-18.

\section{Sims 2003 \{published data only\}}

Sims EJ, Jackson CM, Lipworth BJ. Add-on therapy with montelukast or formoterol in patients with the glycine16 beta2-receptor genotype. British Journal of Clinical Pharmacology 2003;56(1):104-11.

Smith 1998 \{published data only\} Smith LJ. The prospects for long-term intervention in asthma with antileukotrienes. Clinical and Experimental Allergy 1998;28 Suppl 5:154-63.
Sorkness 2007 \{published data only\}

Covar RA, Szefler SJ, Zeiger RS, Sorkness CA, Moss $\mathrm{M}$, Mauger DT, et al.Factors associated with asthma exacerbations during a long-term clinical trial of controller medications in children. The Journal of Allergy and Clinical Immunology 2008;122(4):741-7.

Larsen GL, Morgan W, Heldt GP, Mauger DT, Boehmer SJ, Chinchilli VM, Lemanske RF, et al.Impulse oscillometry versus spirometry in a long-term study of controller therapy for pediatric asthma. The Journal of Allergy and Clinical Immunology 2009;123(4):861-7.

Sorkness CA, Lemanske Jr RF, Mauger DT, Boehmer SJ, Chinchilli VM, Martinez FD, et al.Long-term comparison of 3 controller regimens for mild-moderate persistent childhood asthma: The Pediatric Asthma Controller Trial. The Journal of Allergy and Clinical Immunology 2007;119 (1):64-72.

Stanford 2003 \{published data only\}

Stanford R, Dorinsky P, Crim C, Yancey S, Edwards L, Rickard K. Reduction in asthma related exacerbations and exacerbation related costs during initial maintenance therapy with fluticasone propionate/salmeterol combination product versus montelukast or fluticasone propionate alone. The Journal of Allergy and Clinical Immunology 2003;111 Suppl 2:143.

Stelmach 2001 \{published data only\}

Stelmach I, Grzelewski T, Majak P, Majak J, Bobrowska M, Jerzynska J, et al.The effect of triamcinolone, montelukast and formoterol on serum levels of il-4, $\mathrm{IgE}$ and clinical parameters in children with asthma. Polski Merkuriusz Lekarski 2001;11(63):247-51.

Stelmach 2002 \{published data only\}

Stelmach I, Jerzynska J, Majak P, Grzelewski T, Gorski P, Stelmach W, et al.The effect of triamcinolone acetonide, montelukast, nedocromil sodium, formoterol on levels levels of sICAM-1, sIL-2R in serum and clinical course of asthma in children. Polski Merkuriusz Lekarski 2002;12 (68):99-103.

Stelmach 2002a \{published data only\} Stelmach I, Jerzynska J, Kuna P. A randomized, doubleblind trial of the effect of glucocorticoid, antileukotriene and [beta]-agonist treatment on IL-10 serum levels in children with asthma. Clinical and Experimental Allergy 2002;32(2):264-9.

Stelmach 2007 \{published data only\}

Stelmach I, Grzelewski T, Bobrowska-Korzeniowska M, Stelmach P, Kuna P. A randomized, double-blind trial of the effect of anti-asthma treatment on lung function in children with asthma. Pulmonary Pharmacology \& Therapeutics 2007;20(6):691-700.

Stelmach 2008 \{published data only (unpublished sought but not used)\}

Stelmach I, Grzelewski T, Jerzynska J, Kuna P. A randomized, double-blind trial on the effect of treatment with montelukast, budesonide, montelukast with budesonide, formoterol with budesonide on lung function 
and clinical symptoms in children with asthma [Abstract]. The Journal of Allergy and Clinical Immunology 2005;115 Suppl(2): 151 .

Stelmach I, Grzelewski T, Majak P, Jerzynska J, Stelmach W, Kuna P. Effect of different antiasthmatic treatments on exercise-induced bronchoconstriction in children with asthma. The Journal of Allergy and Clinical Immunology 2008;121(2):383-9.

Stempel 1998 \{published data only\}

Stempel DA. Leukotriene modifiers in the treatment of asthma. Respiratory Care 1998;43(6):481-9.

Stempel 2002 \{published data only\}

Stempel DA, O’Donnell JC, Meyer JW. Inhaled corticosteroids plus salmeterol or montelukast: effects on resource utilization and costs. The Journal of Allergy and Clinical Immunology 2002;109(3):433-9.

Stevenson 2005 \{published data only\} Stevenson DD, Mehra PK, White AA, Gupta S, Woessner KM, Simon RA. Failure of tacrolimus to prevent aspirininduced respiratory reactions in patients with aspirinexacerbated respiratory disease. The Journal of Allergy and Clinical Immunology 2005;116(4):755-60.

Terzano 2001 \{published data only\}

Terzano C, Allegra L, Barkai L, Cremonesi G. Beclomethasone dipropionate versus budesonide inhalation suspension in children with mild to moderate persistent asthma. European Review for Medical and Pharmacological Sciences 2001;5(1):17-24.

Thien 2000 \{published data only\}

Thien F. Leukotriene antagonists - do they offer new hope for asthmatics?. Australian Family Physician 2000;29(6): 547-51.

Tolley 2002 \{published data only\} Tolley K, Martin A, Rice L, McCarthy TP. Salmeterol/ fluticasone propionate combination (SFC) demonstrates improved health outcomes and good cost effectiveness compared with beclomethasone dipropionate. American Journal of Respiratory and Critical Care Medicine 2002;165 Suppl 8:A112.

Vaquerizo 2003 \{published data only\}

Vaquerizo MJ, Casan P, Castillo J, Perpina M, Sanchis J, Sobradillo V, et al.Effect of montelukast added to inhaled budesonide on control of mild to moderate asthma. Thorax 2003;58:204-11.

Volovitz 1999 \{published data only\}

Volovitz B, Tabachnik E, Nussinovitch M, Shtaif B, Blau H, Gil-Ad I, et al.Montelukast, a leukotriene receptor agonist, reduces the concentration of leukotrienes in the respiratory tract of children with persistent asthma. The Journal of Allergy and Clinical Immunology 1999;104:1162-7.

Warner 2001 \{published data only\}

Warner JO. The role of leukotriene receptor antagonists in the treatment of chronic asthma in childhood. Allergy 2001; 56 Suppl 66:22-9.

\section{Wilson $1999\{$ published data only\}}

Wilson AM. A comparison of salmeterol and montelukast as second-line therapy in asthmatic patients not controlled on inhaled corticosteroids. Thorax 1999;54 Suppl 3:A66, P189.

Wilson 2001 \{published data only\}

Wilson AM, Dempsey OJ, Sims EJ, Lipworth BJ. Evaluation of salmeterol or montelukast as second-line therapy for asthma not controlled with inhaled corticosteroids. Chest 2001;119(4):1021-6.

Wytrychowski 2001 \{published data only\}

Wytrychowski K, Patkowski J, Kuzniar T, Malolepszy J. Zafirlucast in corticosteroid sensitive and resistant bronchial asthma [Zafirlukast w leczeniu astmy oskrzelowej wrazliewej i opornej na kortykosteroidy - ocena stanu klinicznego i jakosci zycia]. Advances in Clinical and Experimental Medicine 2001;10(4):337-47.

Yurdakul 2002 \{published data only\} Yurdakul AS, Calisir HC, Tunctan B, Ogretensoy M. Comparison of second controller medications in addition to inhaled corticosteroid in patients with moderate asthma. Respiratory Medicine 2002;96(5):322-9.

Zarkovic 1998 \{published data only\}

Zarkovic J, Gotz MH, Holgate ST, Taak NK. Effect of longterm regular salmeterol treatment in children with moderate asthma. Clinical Drug Investigation 1998;15(3):169-75.

Zimmerman 2002 \{published data only\}

Zimmerman B. Efficacy and tolerability of formoterol turbuhaler ${ }^{\circledR}$ compared with placebo in children (6-11 years) with asthma poorly controlled with inhaled corticosteroids. American Journal of Respiratory and Critical Care Medicine 2002;165 Suppl 8:A746.

\section{References to ongoing studies}

Fardon 2002 \{published data only\}

Ongoing study Starting date of trial not provided. Contact author for more information.

Fardon 2004 \{published data only\}

Ongoing study Starting date of trial not provided. Contact author for more information.

Price 2001 \{published data only\}

Ongoing study Starting date of trial not provided. Contact author for more information.

Ruggins 2003 \{unpublished data only\}

Ongoing study Starting date of trial not provided. Contact author for more information.

\section{Additional references}

\section{Adams 2007}

Adams N, Bestall JM, Lasserson TJ, Jones PW. Fluticasone versus beclomethasone or budesonide for chronic asthma in adults and children. Cochrane Database of Systematic Reviews 2007, Issue 4. [DOI: 10.1002/ 14651858.CD002310.pub4] 
Altman 2003

Altman DG, Bland JM. Statistics Notes: Interaction revisited: the difference between two estimates. BMJ 2003; 326(7382):219.

ATS 1991

American Thoracic Society. Lung function testing: Selection of reference values and interpretative strategies. American Review of Respiratory Disease 1991;144:1202-18.

\section{Baraniuk 1997}

Baraniuk JN, Ali M, Brody D, Maniscalco J, Gaumond E, Fitzgerald T, et al.Glucocorticoids induce beta2-adrenergic receptor function in human nasal mucosa. American Journal of Respiratory and Critical Care Medicine 1997;155(2): 704-10.

\section{Boulet 2001}

Boulet LP, Bai TR, Becker A, Berube D, Beveridge R, Bowie $\mathrm{DM}$, et al.What is new since the last (1999) Canadian Asthma Consensus Guidelines?. Canadian Respiratory Journal 2001;8 Suppl A:5-27.

\section{BTS 2003}

British Thoracic Society. British guidelines on the management of asthma. Thorax 2003;58 Suppl 1:1-94.

\section{Buhl 2003}

Buhl R, Creemers JP, Vondra V, Martelli NA, Naya IP, Ekstrom T. Once-daily budesonide/formoterol in a single inhaler in adults with moderate persistent asthma. Respiratory Medicine 2003;97(4):323-30.

\section{Cates 2002}

Cates CJ. Simpson's paradox and calculation of number needed to treat from meta-analysis. BMC Medical Research Methodology 2002;2:1.

\section{Cates 2008a}

Cates CJ, Cates MJ, Lasserson TJ. Regular treatment with formoterol for chronic asthma: serious adverse events. Cochrane Database of Systematic Reviews. John Wiley \& Sons, Ltd, 2008, issue 4. [DOI: 10.1002/ 14651858.CD006923.pub2; : CD006923]

\section{Cates 2008b}

Cates CJ, Cates MJ. Regular treatment with salmeterol for chronic asthma: serious adverse events. Cochrane Database of Systematic Reviews. John Wiley \& Sons, Ltd, 2008, issue 3. [DOI: 10.1002/14651858.CD006363.pub2; : CD006363]

\section{Cates 2009a}

Cates CJ, Lasserson TJ, Jaeschke R. Regular treatment with formoterol and inhaled steroids for chronic asthma: serious adverse events. Cochrane Database of Systematic Reviews. John Wiley \& Sons, Ltd, 2009, issue 2. [DOI: 10.1002/ 14651858.CD006924.pub2; : CD006924]

\section{Cates 2009b}

Cates CJ, Lasserson TJ, Jaeschke R. Regular treatment with salmeterol and inhaled steroids for chronic asthma: serious adverse events. Cochrane Database of Systematic Reviews. John Wiley \& Sons, Ltd, 2009, issue 3. [DOI: 10.1002/ 14651858.CD006922.pub2; : CD006922]

\section{Davis 1997}

Davies RJ, Wang J, Abdelaziz MM, Calderon MA, Khair $\mathrm{O}$, Devalia JL, et al.New insights into the understanding of asthma. Chest 1997;111 Suppl:2-10.

\section{Deeks 2001}

Deeks JJ, Altman DG, Bradburn MJ. Statistical methods for examining heterogeneity and combining results from several studies in meta-analysis. In: Egger M, Smith GD, Altman DG editor(s). Systematic reviews in health care: meta-analysis in context. London: BMJ Publishing, 2001:285-312.

\section{Ducharme 2004a}

Ducharme FM, Schwartz Z, Kakuma R. Addition of anti-leukotriene agents to inhaled corticosteroids for chronic asthma (Cochrane review). Cochrane Database of Systematic Reviews 2004, Issue 1. [DOI: 10.1002/ 14651858.CD003133.pub2]

\section{Ducharme 2004b}

Ducharme FM, Di Salvio F. Anti-leukotrienes compared to inhaled corticosteroids in the management of recurrent and/ or chronic asthma (Cochrane review). Cochrane Database of Systematic Reviews 2004, Issue 1. [DOI: 10.1002/ 14651858.CD002314.pub2]

\section{Ducharme 2010}

Ducharme FM, Ni Chroinin M, Greenstone I, Lasserson TJ. Addition of long-acting beta2-agonists to inhaled corticosteroids versus same dose inhaled corticosteroids for chronic asthma in adults and children. Cochrane Database of Systematic Reviews 2010, Issue 5. [DOI: 10.1002/ 14651858.CD005535.pub3]

\section{Egger 1997}

Egger M, Smith GD, Schneider M, Minder C. Bias in meta-analysis detected by a simple, graphical test. $B M J$ 1997;315:629-34.

\section{Ernst 2006}

Ernst P, McIvor A, Ducharme FM, Boulet LP, Fitzgerald M, Chapman KR, Bai T. Safety and effectiveness of longacting inhaled beta-agonist bronchodilators when taken with inhaled corticosteroids. Annals of Internal Medicine 2006;145:692-4.

\section{Georgitis 1999}

Georgitis JW. The 1997 asthma management guidelines and therapeutic issues relating to the treatment of asthma. Chest 1999;115:210-7.

\section{GINA 2009}

Global Initiative for Asthma. Global Strategy for Asthma Management and Prevention (updated December 2009). NIH Publication 02-3659. Bethesda, MD: National Heart, Lung and Blood Institute, 2009.

\section{Gold 2001}

Gold M, Jogi R, Mulder PGH, Akveld MLK. Salmeterol/ fluticasone propionate combination $50 / 100 \mathrm{mcg}$ bid is more effective than fluticasone propionate $100 \mathrm{mcg}$ bid plus montelukast $10 \mathrm{mg}$ once daily in reducing exacerbations. European Respiratory Journal 2001;18 Suppl 33:262. 
Higgins 2003

Higgins JP, Thompson SG, Deeks JJ, Altman DG. Measuring inconsistency in meta-analyses. BMJ 2003;327: $557-60$.

\section{Higgins 2008}

Higgins JPT, Green S, editors. Cochrane Handbook for Systematic Reviews of Interventions Version 5.0.1 [updated September 2008]. The Cochrane Collaboration, Available from www.cochrane-handbook.org, 2008.

\section{Johnson 1995}

Johnson M. Pharmacology of long acting beta-agonists. Annals of Allergy, Asthma \& Immunology 1995;75(2):177-9.

\section{Krawiec 2002}

Krawiec ME, Jarjour NJ. Leukotriene receptor antagonists. Seminars in Respiratory and Critical Care Medicine 2002;23 (4):399-410.

\section{Lipworth 2002}

Lipworth BJ. Antagonism of long-acting beta2-adrenoceptor agonism. British Journal of Clinical Pharmacology 2002;54: $231-45$.

\section{Lotvall 1996}

Lotvall J, Lunde H, Svedmyr N. Onset of bronchodilation and finger tremor induced by salmeterol and salbutamol in asthmatic patients. Journal of the American Board of Family Practice 1996;9(3):182-90.

\section{Lougheed 2010}

Lougheed MD, Lemière C, Dell SD, Ducharme FM, Fitzgerald JM, Leigh R, et al.Canadian Thoracic Society Asthma Management Continuum - 2010 Consensus Summary for children six years of age and over, and adults. Canadian Respiratory Journal 2010;17(1):15-24.

\section{Nelson 2003}

Nelson HS, Chapman KR, Pyke SD, Johnson M, Pritchard $\mathrm{JN}$. Enhanced synergy between fluticasone propionate and salmeterol inhaled from a single inhaler versus separate inhalers. The Journal of Allergy and Clinical Immunology 2003;112(1):29-36.

Ni Chroinin 2009a

Ni Chroinin M, Greenstone I, Lasserson TJ, Ducharme FM. Addition of long-acting beta2-agonists to inhaled steroids as first line therapy for persistent asthma in steroid-naive adults and children. Cochrane Database of Systematic Reviews 2009, Issue 4. [DOI: 10.1002/14651858.CD005307.pub2]

\section{Ni Chroinin 2009b}

Ni Chroinin M, Lasserson TJ, Greenstone I, Ducharme FM. Addition of long-acting beta-agonists to inhaled corticosteroids for chronic asthma in children. Cochrane Database of Systematic Reviews 2009, Issue 3. [DOI: 10.1002/14651858.CD005535.pub2]

\section{Perera 2003}

Perera BJ. Salmeterol multicentre asthma research trial (SMART): interim analysis shows increased risk of asthma related deaths. Ceylon Medical Journal 2003;48(3):99.

\section{Powell 2003}

Powell H, Gibson PG. Inhaled corticosteroid doses in asthma: an evidence-based approach [Review]. Medical Journal of Australia 2003;178(5):223-5.

\section{Rees 1995}

Rees J, Price J. ABC of Asthma: Treatment of chronic asthma. BMJ 1995;310:1459-63.

\section{Review Manager 5}

Copenhagen, The Nordic Cochrane Centre: The Cochrane Collaboration. Review Manager (RevMan) Version 5.0. Copenhagen, The Nordic Cochrane Centre: The Cochrane Collaboration, 2008.

\section{Salpeter 2006}

Salpeter SR, Buckley NS, Ormiston TM, Salpeter EE. Meta-analysis: effect of long-acting beta-agonists on severe asthma exacerbations and asthma-related deaths. Annals of Internal Medicine 2006;144(12):904-12.

\section{Storms 2003}

Storms W. Clinical trials: are these your patients?. The Journal of Allergy and Clinical Immunology 2003;112 Suppl (5):107-11.

\section{USA 2002}

National Asthma Education and Prevention Program. NAEPP Expert Panel Report Guidelines for the Diagnosis and Management of Asthma. NIH Publication 02-5075. National Heart, Lung and Blood Institute. Bethesda, MD: National Institute of Health, 2002:1-111.

\section{Walters 2007}

Walters EH, Gibson PG, Lasserson TJ, Walters JAE. Long-acting beta2-agonists for chronic asthma in adults and children where background therapy contains varied or no inhaled corticosteroid. Cochrane Database of Systematic Reviews 2007, Issue 1. [DOI: 10.1002/ 14651858.CD001385.pub2]

\section{Wasserman 1988}

Wasserman MA. Modulation of arachidonic acid metabolites as potential therapy of asthma. Agents and Actions. Supplements 1988;23:95-111.

\section{Wenzel 1997}

Wenzel SE. Arachidonic acid metabolites: mediators of inflammation in asthma. Pharmacotherapy 1997;17(1Pt 2): $3 S-12 S$.

\section{References to other published versions of this review}

\section{Ducharme 2006}

Ducharme FM, Lasserson TJ, Cates CJ. Long-acting beta2-agonists versus anti-leukotrienes as add-on therapy to inhaled corticosteroids for chronic asthma. Cochrane Database of Systematic Reviews 2006, Issue 4. [DOI: 10.1002/14651858.CD003137]

\section{Ram 2005}

Ram FSF, Cates CJ, Ducharme FM. Long-acting beta2agonists versus anti-leukotrienes as add-on therapy to inhaled corticosteroids for chronic asthma. Cochrane 
Database of Systematic Reviews 2005, Issue 1. [DOI:

10.1002/14651858.CD003137]

* Indicates the major publication for the study 
CHARACTERISTICS OF STUDIES

Characteristics of included studies [ordered by study ID]

Bjermer 2003

\begin{tabular}{|c|c|}
\hline Methods & Parallel-group, multicentre trial (148 centres in 37 countries) \\
\hline Participants & $\begin{array}{l}\text { INADEQUATELY controlled participants on inhaled glucocorticoids at baseline } \\
\text { BASELINE INHALED STEROID DOSAGE: } \\
\text { LTRA: } 638 \pm 285 \mu \text { of beclomethasone-equivalent/day } \\
\text { LABA: } 647 \pm 229 \mu \text { of beclomethasone-equivalent/day } \\
\text { RANDOMISED: } 1490 \text { (LTRA: } 747 \text {; LABA: } 743 \text { ) } \\
\text { WITHDRAWALS: } \\
\text { LTRA: } 125 \text { (17\%) } \\
\text { LABA: } 110 \text { (15\%) } \\
\text { AGE in years: mean } \pm \text { SD } \\
\text { LTRA: } 41.2 \pm 13.6 \\
\text { LABA: } 41.0 \pm 13.7 \\
\text { GENDER (\% male) } \\
\text { LTRA: } 45.4 \% \\
\text { LABA: } 44.8 \% \\
\text { SEVERITY: } \\
\text { MODERATE asthma } \\
\text { BASELINE } \% \text { PRED FEV1 } \\
\text { LTRA: } 71.3 \pm 13.2 \\
\text { LABA: } 72.7 \pm 13.9 \\
\text { ALLERGIC RHINITIS: } \\
\text { LTRA: } 61.7 \% \\
\text { LABA: } 60.4 \% \\
\text { ALLERGEN TRIGGERS: } \\
\text { Not reported } \\
\text { ASTHMA DURATION in years: mean } \pm \text { SD } \\
\text { LTRA: } 16.3 \pm 13.0 \\
\text { LABA: } 16.2 \pm 12.7 \\
\text { ELIGIBILITY CRITERIA: age: } 15-72 \text { years; clear history of chronic asthma for at least } \\
1 \text { year; regular use of inhaled corticosteroids over } 8 \text { weeks prior to study entry; FEV1 } \\
\text { values between } 50 \% \text { and } 90 \% \text { of predicted; } \geq 12 \% \text { improvement in FEV1 or PEFR after } \\
\text { B-agonists; minimum pre-determined level of daytime and night-time inhaled short- } \\
\text { acting } 3 \text {-agonist use ( } \geq 1 \text { puff/day); minimum asthma symptom score (biweekly score of } \\
\geq 56 \text { on a scale of } 0 \text { to } 336) \text {; current treatment includes only short-acting beta2-agonists } \\
\text { and inhaled corticosteroids ( } 200-1000 \mu \text { } 4 \text { /day or equivalent); women with negative urine } \\
\text { pregnancy test at screening } \\
\text { EXCLUSION CRITERIA: emergency treatment for asthma within } 1 \text { month of } 1 \text { st visit; } \\
\text { hospitalisation for asthma within } 3 \text { months; unresolved upper respiratory tract infection } \\
\text { within } 3 \text { weeks; active sinus infection; received the following asthma medications: oral } \\
\text { corticosteroids within } 1 \text { month, cromolyn, nedocromil, leukotriene-receptor antagonists, } \\
\text { long-acting or oral } \text { } \text {-agonists, inhaled anticholinergics within } 2 \text { weeks, theophylline, } \\
\text { terfenadine, fexofenadine, loratadine, or cetirizine within } 1 \text { week }\end{array}$ \\
\hline
\end{tabular}


Bjermer 2003 (Continued)

Interventions
LTRA + ICS versus LABA + ICS (stable dose of ICS)
DURATION:
Run-in period: 4 weeks
Intervention period: 48 weeks
INTERVENTION GROUP 1
LTRA: montelukast @ $10 \mathrm{mg} /$ day p.o. + ICS (FP $100 \mu \mathrm{g}$ bid, via discus)
INTERVENTION GROUP 2
LABA: salmeterol 50 ug bid, via MDI + ICS (FP $100 \mu \mathrm{g}$ bid, via Discus)
2 inhalers used for combination therapy.
CO-TREATMENT: none

Outcomes

INTENTION-TO-TREAT ANALYSES

Outcomes used at endpoint or 48 weeks

PULMONARY FUNCTION TESTS

Change from baseline FEV; change from baseline in am PEFR

SYMPTOM SCORES

Change from baseline NIGHT-TIME awakenings

**EXACERBATIONS

Exacerbations requiring systemic steroids; exacerbations requiring hospital admission; exacerbations requiring unscheduled office visit; exacerbations requiring emergency room visit; time to first exacerbation

Definition: an asthma attack was defined by one or all of the following, hospitalisation; unscheduled office visit; ER visit; CS use (oral, IM, IV or rectal use)

FUNCTIONAL STATUS

Change in quality of life; change in night-time awakenings

INFLAMMATORY MARKERS

Change in serum eosinophils

ADVERSE EFFECTS

Elevated liver enzymes, headache, nausea, death, neutropenia, increased lymphocytes WITHDRAWALS

Due to adverse effects; due to poor control; overall

(** denotes primary outcome)

Notes

Full-text report; additional unpublished data provided by Peter Polos, June 2003

Funder: Merck Frost

Confirmation of methodology and data extraction: received (Peter Polos, June 2003)

User-defined number: 48 weeks

Risk of bias

\begin{tabular}{l|l|l} 
Bias & Authors' judgement & Support for judgement \\
\hline $\begin{array}{l}\text { Random sequence generation (selection } \\
\text { bias) }\end{array}$ & Low risk & $\begin{array}{l}\text { Randomisation by computer generated } \\
\text { random numbers }\end{array}$ \\
\hline Allocation concealment (selection bias) & Low risk & $\begin{array}{l}\text { Allocation occurred at pharmacy and not } \\
\text { conducted by investigator }\end{array}$
\end{tabular}


Bjermer 2003 (Continued)

\begin{tabular}{l|l|l}
$\begin{array}{l}\text { Blinding (performance bias and detection } \\
\text { bias) } \\
\text { All outcomes }\end{array}$ & Low risk & $\begin{array}{l}\text { Number coded MDI/tablets supplied by } \\
\text { pharmacy } \\
\text { Tripple-blind (patient, assessor and treat- } \\
\text { ing physician); double-dummy (identical } \\
\text { placebo) }\end{array}$ \\
\hline $\begin{array}{l}\text { Incomplete outcome data (attrition bias) } \\
\text { Exacerbations }\end{array}$ & Unclear risk & $\begin{array}{l}\text { Intention-to-treat analysis reported, but } \\
\text { method not available }\end{array}$ \\
\hline Selective reporting (reporting bias) & Low risk & Data obtained from investigators \\
\hline \begin{tabular}{l} 
Other bias \\
\hline
\end{tabular} & Low risk & \\
\hline
\end{tabular}

Ceylan 2004

Methods

Parallel-group; single centre study (Turkey)

Participants

INADEQUATELY controlled participants on inhaled glucocorticoids and SABA prn BASELINE INHALED STEROID DOSAGE

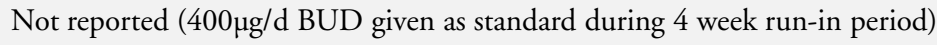

RANDOMISED

48. NB baseline data only reported for those who completed the study: LTRA: 20; LABA: 20

\section{WITHDRAWALS:}

Not stated by treatment group

AGE in years, mean:

LTRA: 33.2

LABA: 39.1

GENDER (\% male):

LTRA: 55

LABA: 50

SEVERITY

Moderate persistent asthma

BASELINE \% PRED FEV1 (L):

LTRA: 69.7

LABA: 71.2

ALLERGIC RHINITIS (\%):

LTRA: 60

LABA: 70

ALLERGEN TRIGGERS

Not reported

ASTHMA DURATION in years: Mean \pm SD:

LTRA: $8.1 \pm 4$

LABA: $9 \pm 8.8$

ELIGIBILITY CRITERIA: age 15-60 years; diagnosis of asthma (GINA); persistent asthma symptoms for at least 1 year; use of ICS for at least 6 months; post-run in period: FEV 1 or $\mathrm{PEF} \geq 60$ and $\leq 80 \%$ predicted 


\begin{tabular}{|c|c|}
\hline & $\begin{array}{l}-\geq 15 \% \text { reversibility increase in FEV1; mean am PEF value } \leq 85 \% \text { max after SABA; use } \\
\text { of SABA } \geq 2 \text { times per day or am/night symptom score } \geq 2 \text { on } 4 \text { or less days per week } \\
\text { EXCLUSION CRITERIA: smokers; pregnant or lactating women; life-threatening } \\
\text { asthma; patients hospitalised due to asthma in last } 3 \text { months; upper/lower RTI }\end{array}$ \\
\hline Interventions & $\begin{array}{l}\text { LTRA + ICS versus LABA + ICS (stable dose of ICS) } \\
\text { DURATION: } \\
\text { Run-in period: } 4 \text { weeks } \\
\text { Intervention period: } 8 \text { weeks } \\
\text { Outcomes at } 4,8 \text {, and } 12 \text { weeks } \\
\text { INTERVENTION GROUP } 1 \\
\text {-LTRA = montelukast @ } 10 \mathrm{mg} \text { /day p.o.+ BUD } 200 \mu \mathrm{g} \text { BID, unclear inhaler device } \\
\text { INTERVENTION GROUP } 2 \\
\text {-LABA = formoterol } 12 \mu \mathrm{g} \text { bid,+ BUD } 200 \mu \mathrm{g} \text { BID, unclear inhaler device } \\
\text { CO-TREATMENT: } \\
\text {-SABA prn }\end{array}$ \\
\hline Outcomes & $\begin{array}{l}\text { PULMONARY FUNCTION TESTS } \\
\text { Change in FEV1 \% predicted; change in FEV1 (L); change in am PEF*; change in pm } \\
\text { PEF } \\
\text { SYMPTOM SCORES } \\
\text { Morning symptom scores; night symptom scores } \\
\text { EXACERBATIONS } \\
\text { Not reported (participants who exacerbated were excluded from the study) } \\
\text { FUNCTIONAL STATUS } \\
\text { Rescue medication usage (puffs/d); \% days without rescue medication usage } \\
\text { INFLAMMATORY MARKERS } \\
\text { Not reported } \\
\text { EXACERBATIONS } \\
\text { Need for a drug not included in the protocol } \\
\text { ADVERSE EFFECTS } \\
\text { Candidiasis; sore throat; voice problems; headache } \\
\text { WITHDRAWALS } \\
\text { Not clear } \\
\text {-Due to ADVERSE EFFECTS } \\
\text { Not reported } \\
\text {-Due to poor control } \\
\text { Not reported } \\
\text {-Overall } \\
\text { Stated } \\
\text { * Main outcome }\end{array}$ \\
\hline Notes & $\begin{array}{l}\text { Full-text report } \\
\text { No funding body } \\
\text { User-defined number: } 8 \text { weeks }\end{array}$ \\
\hline
\end{tabular}

Risk of bias

Bias

Authors' judgement

Support for judgement 


\section{Ceylan 2004 (Continued)}

\begin{tabular}{|c|c|c|}
\hline $\begin{array}{l}\text { Random sequence generation (selection } \\
\text { bias) }\end{array}$ & Unclear risk & Not reported \\
\hline Allocation concealment (selection bias) & Unclear risk & Not reported \\
\hline $\begin{array}{l}\text { Blinding (performance bias and detection } \\
\text { bias) } \\
\text { All outcomes }\end{array}$ & High risk & Open-label study \\
\hline $\begin{array}{l}\text { Incomplete outcome data (attrition bias) } \\
\text { Exacerbations }\end{array}$ & Unclear risk & $\begin{array}{l}\text { Stated ITT for efficacy and safety, however } \\
\text { baseline data are only presented for } 40 \text { par- } \\
\text { ticipants who completed the study }\end{array}$ \\
\hline Selective reporting (reporting bias) & Unclear risk & $\begin{array}{l}\text { Unable to verify whether primary outcome } \\
\text { measured in the review }\end{array}$ \\
\hline Other bias & Low risk & \\
\hline
\end{tabular}

\section{ELEVATE}

Methods

Participants
Parallel group, pragmatic randomised controlled study in primary care population in the UK

INADEQUATELY controlled participants on inhaled glucocorticoids at baseline BASELINE INHALED STEROID DOSAGE

Not specified

RANDOMISED:

LTRA: 164

LABA: 176

WITHDRAWALS

Not specified (12 participants withdrew from treatment)

AGE in years: mean $\pm S D$

Not reported

GENDER (\% male)

Not reported

SEVERITY

Not described

BASELINE PEF (\% predicted)

LTRA: 89.2

LABA: 87

ALLERGEN TRIGGERS

Not reported

ALLERGIC RHINITIS

Not reported

ASTHMA DURATION in years

Not reported

ELIGIBILITY CRITERIA

$>11$ years; PEF predicted $>50 \%$; inadequately controlled on inhaled corticosteroids 
ELEVATE (Continued)

\section{EXCLUSION CRITERIA}

Not listed

SETTING: primary care

\begin{tabular}{ll}
\hline Interventions & $\begin{array}{l}\text { DURATION: 2 years } \\
\text { 1. LTRA (not specified from abstract) } \\
\text { 2. LABA (not specified from abstract) }\end{array}$ \\
\hline Outcomes & $\begin{array}{l}\text { Asthma quality of life (AQLQ); exacerbations; asthma control questionnaire; PEF \% } \\
\text { predicted; symptoms; SABA usage; hospital admission; change in ICS (for participants } \\
\text { at step 3) }\end{array}$ \\
\hline Notes & TJL emailed for data: 22nd April, 2010. \\
\hline
\end{tabular}

\section{Risk of bias}

\begin{tabular}{|c|c|c|}
\hline Bias & Authors' judgement & Support for judgement \\
\hline $\begin{array}{l}\text { Random sequence generation (selection } \\
\text { bias) }\end{array}$ & Unclear risk & Pragmatic randomised controlled trial \\
\hline Allocation concealment (selection bias) & Low risk & $\begin{array}{l}\text { Centralised 'ring-in' centre for randomisa- } \\
\text { tion }\end{array}$ \\
\hline $\begin{array}{l}\text { Blinding (performance bias and detection } \\
\text { bias) } \\
\text { All outcomes }\end{array}$ & High risk & Single-blind (to study personnel) \\
\hline $\begin{array}{l}\text { Incomplete outcome data (attrition bias) } \\
\text { Exacerbations }\end{array}$ & Low risk & $\begin{array}{l}\text { Low withdrawal rates }(12 / 352) \text { unlikely to } \\
\text { affect results }\end{array}$ \\
\hline Selective reporting (reporting bias) & High risk & $\begin{array}{l}\text { Study presented as conference abstract. } \\
\text { Outcomes within it well reported, but } \\
\text { no information presented on exacerbations } \\
\text { and SAEs. Trial protocol indicates that ex- } \\
\text { acerbations were measured }\end{array}$ \\
\hline Other bias & Unclear risk & $\begin{array}{l}\text { No full-text article presenting clinical end- } \\
\text { points available to determine this }\end{array}$ \\
\hline
\end{tabular}

\section{Fish 2001}

\begin{tabular}{ll} 
Methods & Parallel-group study, multicentre trial (71 centres in USA and Puerto Rico) \\
\hline Participants & INADEQUATELY controlled participants on inhaled glucocorticoids at baseline \\
& BASELINE INHALED STEROID DOSAGE: \\
& 84-4000 $\mu$ g of beclomethasone-equivalent/day \\
& RANDOMISED: 948
\end{tabular}


Fish 2001 (Continued)

LTRA: 47

LABA: 476

WITHDRAWALS:

LTRA: 70 (15\%)

LABA: 61 (13\%)

AGE in years: mean $\pm \mathrm{SD}$

LTRA: $39.5 \pm 14.0$

LABA: $39.9 \pm 13.5$

GENDER (\% male)

LTRA: $38 \%$

LABA: $39 \%$

SEVERITY:

Not described

BASELINE FEV1 (\% pred)

LTRA: 68.6 (0.4) SE

LABA: $68.1(0.4) \mathrm{SE}$

ALLERGEN TRIGGERS

Not reported

ASTHMA DURATION in years: \%

Less than 10 years

LTRA: $26 \%$

LABA: $24 \%$

Over 10 years

LTRA: $74 \%$

LABA: $76 \%$

ELIGIBILITY CRITERIA: aged $\geq 15$ years; male or non-pregnant, non-lactating female; asthma for $\geq 6$ months; symptomatic despite ICS for at least 6 weeks prior to screening; $50-80 \%$ predicted $\mathrm{FEV} 1 ; \geq 12 \%$ increase in $\mathrm{FEV} 1$ post-bronchodilator (200 $\mu \mathrm{g}$ albuterol)

In the 7 to 14 days prior to randomisation one or more of the following:

1. FEV1 of 50 to $80 \%$ of predicted

2. average of 4 or more puffs per day albuterol

3. symptom score of 2 or more for 3 or more days

4. 3 or more nights when patient woke at night due to asthma symptoms EXCLUSION CRITERIA

Not described

SETTING: outpatients in private and university clinics

Run-in period: $1-2$ weeks

Intervention period: 12 weeks

INTERVENTION GROUP 1

LTRA: montelukast $10 \mathrm{mg}$ qd + ICS: continued current medication (which included fluticasone, triamcinolone, BDP, BUD and flunisolide) Mean $565 \mu \mathrm{g}$ in CFC BDPequivalent)

INTERVENTION GROUP 2

LABA: salmeterol $50 \mu \mathrm{g}$ bid, via Diskus + ICS: continued current medication Mean $546 \mu \mathrm{g}$ in CFC BDP-equivalent 
Fish 2001 (Continued)

2 inhalers used for combination therapy

CO-TREATMENT: none permitted

\begin{tabular}{|c|c|}
\hline Outcomes & $\begin{array}{l}\text { INTENTION-TO-TREAT ANALYSES } \\
\text { Outcomes used at endpoint } \\
\text { PULMONARY FUNCTION TESTS } \\
\text { **Change from baseline in AM PEFR; change from baseline in pm PEFR } \\
\text { SYMPTOM SCORES } \\
\text { Change from baseline overall symptom scores; change in symptom-free days; patient } \\
\text { satisfaction } \\
\text { EXACERBATIONS } \\
\text { Definition: any worsening of asthma symptoms requiring treatment beyond the use of } \\
\text { blinded study drug and/or supplemental albuterol. Patients who experienced an asthma } \\
\text { exacerbation were withdrawn from the study } \\
\text { FUNCTIONAL STATUS } \\
\text { Change from baseline in mean overall use of B2-agonists (puffs/DAY); change from } \\
\text { baseline in mean DAYTIME use of B2-agonists (puffs/DAY); change from baseline in } \\
\text { mean NIGHT-TIME use of B2-agonists (puffs/DAY); change in rescue-free days; change } \\
\text { in night-time awakenings } \\
\text { INFLAMMATORY MARKERS } \\
\text { Not reported } \\
\text { ADVERSE EFFECTS } \\
\text { Drug related and non-drug related } \\
\text { WITHDRAWALS } \\
\text { Due to adverse effects reported } \\
\text { (** denotes primary outcome) }\end{array}$ \\
\hline Notes & $\begin{array}{l}\text { Full-text report } \\
\text { Received additional unpublished data provided by Karen Richardson, GSK, UK, August } \\
2003 \\
\text { Funded by Glaxo Wellcome, studies SMS } 40003 \text { \& SMS } 40004 \\
\text { Confirmation of methodology and data extraction received } \\
\text { User-defined order: } 12 \text { weeks }\end{array}$ \\
\hline
\end{tabular}

\section{Risk of bias}

\begin{tabular}{l|l|l}
\hline Bias & Authors judgement & Support for judgement \\
\hline $\begin{array}{l}\text { Random sequence generation (selection } \\
\text { bias) }\end{array}$ & Low risk & $\begin{array}{l}\text { Methods of randomisation: by computer } \\
\text { generated random number }\end{array}$ \\
\hline $\begin{array}{l}\text { Allocation concealment (selection bias) } \\
\text { Low risk }\end{array}$ & $\begin{array}{l}\text { Means of assignment by number coded in- } \\
\text { haler/pills supplied by pharmacy }\end{array}$ \\
\hline $\begin{array}{l}\text { Blinding (performance bias and detection } \\
\text { bias) } \\
\text { All outcomes }\end{array}$ & Low risk & Double-blind, double-dummy design \\
\hline
\end{tabular}


Fish 2001 (Continued)

\begin{tabular}{l|l|l}
\hline $\begin{array}{l}\text { Incomplete outcome data (attrition bias) } \\
\text { Exacerbations }\end{array}$ & Low risk & $\begin{array}{l}\text { Received additional unpublished data pro- } \\
\text { vided by Karen Richardson, GSK, UK, Au- } \\
\text { gust } 2003\end{array}$ \\
\hline Selective reporting (reporting bias) & Low risk & $\begin{array}{l}\text { Primary outcome data available for meta- } \\
\text { analysis }\end{array}$ \\
\hline Other bias & Low risk & \\
\hline
\end{tabular}

Green 2006

\begin{tabular}{|c|c|}
\hline Methods & Crossover, single centre study in UK \\
\hline Participants & $\begin{array}{l}\text { INADEQUATELY controlled participants on inhaled glucocorticoids at baseline } \\
\text { BASELINE INHALED STEROID DOSAGE: } \\
\leq 400 \mu \mathrm{g} \text { BDP equivalent } \\
\text { N RANDOMISED: } 49 \\
\text { N COMPLETED: } 39 \\
\mathrm{M}=25 \\
\text { F }=24 \\
\text { MEAN AGE: } 42 \\
\text { SEVERITY: not stated } \\
\text { BASELINE FEV1: } 74.8 \% \\
\text { ATOPIC: } 93 \% \\
\text { INCLUSION CRITERIA: } 18-75 \text { yrs, diagnosed with asthma; receiving treatment with } \\
\text { less than or equal to } 400 \mu \text { gg/day CFC-BDP per day; one or more of } 1 \text { ) }>15 \% \text { increase in } \\
\text { FEV1 post-SABA; } 2 \text { ) }>20 \% \text { within-day variability in PEF assessed twice daily over a } 2- \\
\text { week period; } 3 \text { ) provocative concentration of methacholine causing a } 20 \% \text { fall in FEV1 } \\
\text { (PC20) }<8 \text { mg/mL-1; following run-in on } 200 \text { mcg day BUD, participants were eligible } \\
\text { if they had recorded day- or night-time asthma symptoms on their diary cards on at least } \\
4 \text { days in the third or fourth baseline week } \\
\text { EXCLUSION: current smokers or smoking history of }>10 \text { pack-yrs, significant comor- } \\
\text { bidity, treated with oral corticosteroids, long-acting } 32 \text {-agonists, leukotriene antagonists } \\
\text { or theophylline; asthma exacerbation or lower respiratory tract infection within the } 4 \\
\text { weeks prior to trial entry }\end{array}$ \\
\hline Interventions & $\begin{array}{l}\text { LTRA + ICS versus LABA + ICS (Stable low dose of ICS) } \\
\text { INTERVENTION GROUP } 1 \\
\text { LTRA: oral montelukast } 10 \text { mg qd + budesonide } 100 \text { mg BID } \\
\text { INTERVENTION GROUP } 2 \\
\text { LABA: formoterol } 12 \text { mg BID + budesonide } 100 \text { mg BID } \\
\text { TREATMENT PERIOD: } 6 \text { weeks (wash-out period: } 4 \text { weeks) } \\
\text { RUN-IN PERIOD: } 4 \text { weeks } \\
\text { CO-TREATMENT: not reported }\end{array}$ \\
\hline Outcomes & $\begin{array}{l}\text { INTENTION-TO-TREAT ANALYSES: Crossover data analysed for completers } \\
\text { PULMONARY FUNCTION TESTS: } \\
\text { FEV1, PEFR but only improvements when groups compared, no individual group results }\end{array}$ \\
\hline
\end{tabular}


Green 2006 (Continued)

\begin{tabular}{ll} 
& were presented \\
SYMPTOM SCORES: & VAS (individual group values not presented, but rather differences between groups) \\
& EXACERBATIONS \\
Reported as events \\
FUNCTIONAL STATUS \\
Not stated \\
INFLAMMATORY MARKERS \\
Not stated \\
ADVERSE EFFECTS \\
Not stated \\
WITHDRAWALS \\
Not reported \\
\hline Fotes & Funding source not disclosed \\
Confirmation of methodology and data extraction received \\
User-defined order: 4 weeks \\
\hline
\end{tabular}

Risk of bias

\begin{tabular}{|c|c|c|}
\hline Bias & Authors' judgement & Support for judgement \\
\hline $\begin{array}{l}\text { Random sequence generation (selection } \\
\text { bias) }\end{array}$ & Low risk & $\begin{array}{l}\text { 'I believe that this was generated using a com- } \\
\text { puter statistical package generating a random se- } \\
\text { quence. I don't know the package that was used } \\
\text { and unfortunately the individual has left our or- } \\
\text { ganisation but had extensive clinical trials exper- } \\
\text { tise.' }\end{array}$ \\
\hline Allocation concealment (selection bias) & Low risk & $\begin{array}{l}\text { '...this was indeed generated by a third party } \\
\text { namely the pharmacist responsible for dispens- } \\
\text { ing the double blind medication (...) None of the } \\
\text { study investigators were aware of the randomi- } \\
\text { sation schedule until the last patient had com- } \\
\text { pleted the cross-over study' }\end{array}$ \\
\hline
\end{tabular}

Blinding (performance bias and detection Low risk

Double-dummy

bias)

All outcomes

\begin{tabular}{l|l|l}
\hline $\begin{array}{l}\text { Incomplete outcome data (attrition bias) } \\
\text { Exacerbations }\end{array}$ & High risk & Completers used for analysis \\
\hline Selective reporting (reporting bias) & Low risk & $\begin{array}{l}\text { OCS-treated exacerbations reported. Data could } \\
\text { not be extracted as only data on events and not } \\
\text { number of participants were made available }\end{array}$ \\
\hline Other bias & Low risk & \\
\hline
\end{tabular}




\begin{tabular}{|c|c|}
\hline Methods & Parallel group, open-label study; multicentre study (115 centres in France) \\
\hline Participants & $\begin{array}{l}\text { INADEQUATELY controlled participants on inhaled glucocorticoids at baseline } \\
\text { BASELINE INHALED STEROID DOSAGE } \\
1000 \mu \text { g CFC Beclomethasone or equivalent daily. } \\
\text { RANDOMISED = } 253 \\
\text { LTRA: } 130 \\
\text { LABA: } 123 \\
\text { WITHDRAWALS } \\
\text { LTRA: } 16 \text { (12\%) } \\
\text { LABA: } 7 \text { (6\%) } \\
\text { AGE in years: mean } \pm \text { SD } \\
\text { LTRA: } 44.6 \text { (18.2) } \\
\text { LABA: } 43.1 \text { (17.8) } \\
\text { GENDER (\% male) } \\
\text { LTRA: } 39 \\
\text { LABA: } 39 \\
\text { SEVERITY } \\
\text { Not described } \\
\text { BASELINE \% PRED FEV1 (L) } \\
\text { Not reported } \\
\text { BASELINE PEF (L/min): } \\
\text { LTRA: } 327 \\
\text { LABA: } 344 \\
\text { ALLERGIC RHINITIS (\%): } \\
\text { LTRA: } 51 \% \\
\text { LABA: } 52 \% \\
\text { ALLERGEN TRIGGERS } \\
\text { Not reported } \\
\text { ASTHMA DURATION in years: Mean } \pm \text { SD } \\
\text { Reported as \% with asthma duration: } \\
<1 \text { year: } 6 \text {; between } 1 \text { and } 5 \text { years: } 17 \text {; between } 5 \text { and } 10 \text { years: } 15 \text {; between } 10 \text { and } 15 \\
\text { years: } 19 \text {; more than } 15 \text { years: } 43 \\
\text { ELIGIBILITY CRITERIA: less than or equal to } 15 \text { years of age diagnosed asthma; } \\
\text { treatment for at least four weeks with CFC BDP equivalent of } \geq 1000 \text { } 4 \mathrm{dg} \text { and inhaled } \\
\text { SABA prn; able to use Mini Wright PEF metre; able to fill in daily record card } \\
\text { Over last seven days of run-in: } \\
\text { EXCLUSION CRITERIA: use of systemic CS, anti-leukotriene agent, LABA, lower } \\
\text { 2. asthma symptoms on at least two days } \\
\text { ity to one of compound study drugs; serious uncontrolled concurrent disease; allergen } \\
\text { specific immunotherapy in incremental phase; smoker or ex-smoker with } 10 \text { pack year; } \\
\text { participation in clinical study in previous month }\end{array}$ \\
\hline Interventions & $\begin{array}{l}\text { LTRA + ICS versus LABA + ICS (stable dose of ICS) } \\
\text { DURATION: } \\
\text { Run-in period: } 1-2 \text { weeks } \\
\text { Intervention period: } 12 \text { weeks }\end{array}$ \\
\hline
\end{tabular}


INTERVENTION GROUP 1

LTRA: montelukast @ $10 \mathrm{mg} /$ day p.o.+ CFC BDP 250 ug two puffs bid, via pMDI INTERVENTION GROUP 2

LABA: salmeterol 50 ug bid, via MDI + FP $250 \mathrm{mcg}$ one puff bid, via diskus (single combination inhaler)

CO-TREATMENT: SABA prn

Outcomes

Notes
INTENTION-TO-TREAT ANALYSES outcomes used at endpoint or 12 weeks PULMONARY FUNCTION TESTS

${ }^{* *}$ change from baseline in AM PEF; change from baseline in pm PEFR SYMPTOM SCORES

Change from baseline \% nights with awakenings; change from baseline in $\%$ days with no symptoms; change from baseline in \% nights with no symptoms

\section{EXACERBATIONS}

One or more of:

Mild: reduction in AM PEF of $>20 \%$ of baseline; increased bronchodilator usage; awakenings due to asthma on one or more consecutive nights

Moderate: reduction in AM PEF $>30 \%$ of baseline; change in maintenance therapy or premature termination of trial therapy; oral steroids

Severe: hospitalisation

FUNCTIONAL STATUS

Change from baseline in \% nights without rescue medication usage; change from baseline in $\%$ days without rescue medication usage; \% of patients with good asthma control 10 of 12 weeks as defined by presence of two of:

1. $\mathrm{PEF} \geq 80 \%$ predicted

2. no more than four puffs of $\mathrm{BD}$ on no more than 2 days

3. symptom free for at least two days;

4. presence of all the following criteria on a weekly basis: no nocturnal awakening; no exacerbation; no unscheduled medical contact; no adverse effect of treatment leading to withdrawal)

\section{INFLAMMATORY MARKERS}

Not reported

ADVERSE EFFECTS

Headache; gastroenteritis; upper respiratory inflammation; pharyngitis; viral respiratory infections; malaise and fatigue; allergic rhinitis; diarrhoea; digestive discomfort \& pain; ENT symptoms; muscle cramps and spasms; regurgitation and reflux; nasal inflammation; vertigo; nausea and vomiting; cough; lower respiratory infections; dyspeptic symptoms

\section{WITHDRAWALS}

Due to poor completion of diary cards; due to adverse effects; due to poor control -overall (all reported)

(** denotes primary outcome)

Full-text report and unpublished trial report

Received additional unpublished data (SFCF4007) from GSK website

Funded by GSK

User-defined number: 12 weeks

Risk of bias 
Grosclaude 2003 (Continued)

\begin{tabular}{|c|c|c|}
\hline Bias & Authors' judgement & Support for judgement \\
\hline $\begin{array}{l}\text { Random sequence generation (selection } \\
\text { bias) }\end{array}$ & Low risk & See Appendix 1 \\
\hline Allocation concealment (selection bias) & Low risk & See Appendix 1 \\
\hline $\begin{array}{l}\text { Blinding (performance bias and detection } \\
\text { bias) } \\
\text { All outcomes }\end{array}$ & High risk & Open-label study \\
\hline $\begin{array}{l}\text { Incomplete outcome data (attrition bias) } \\
\text { Exacerbations }\end{array}$ & Unclear risk & $\begin{array}{l}\text { 'The safety population included all sub- } \\
\text { jects who received at least } 1 \text { dose of the } \\
\text { study medication. The intent-to-treat pop- } \\
\text { ulation (ITT) included all randomised sub- } \\
\text { jects who received at least one dose of the } \\
\text { study medication, and from whom daily } \\
\text { record card (DRC) data were available dur- } \\
\text { ing the run-in period and the treatment pe- } \\
\text { riod.' }\end{array}$ \\
\hline Selective reporting (reporting bias) & Low risk & $\begin{array}{l}\text { Data for exacerbations reported in phar- } \\
\text { maceutical company download. The defi- } \\
\text { nition of exacerbation was not explicit and } \\
\text { we could not used the outcome data for this } \\
\text { study in the meta-analysis }\end{array}$ \\
\hline Other bias & Low risk & \\
\hline
\end{tabular}

Hendeles 2004

\begin{tabular}{ll}
\hline Methods & Parallel groups; number of sites and countries unclear \\
\hline Participants & INADEQUATELY controlled participants on inhaled glucocorticoids and SABA prn \\
with history of EIB at baseline \\
BASELINE INHALED STEROID DOSAGE \\
Not reported \\
RANDOMISED = 91 (unclear allocation between groups) \\
WITHDRAWALS \\
Not reported \\
AGE in years (range) \\
15-60 \\
GENDER (\% male) \\
Not reported \\
SEVERITY \\
Not described \\
BASELINE $\%$ PRED FEV1 (L) \\
LTRA: 81.3
\end{tabular}


Hendeles 2004 (Continued)

\begin{tabular}{|c|c|}
\hline & $\begin{array}{l}\text { LABA: } 78.9 \\
\text { ALLERGIC RHINITIS (\%) } \\
\text { Not reported } \\
\text { ALLERGEN TRIGGERS } \\
\text { Not reported } \\
\text { ASTHMA DURATION in years: Mean } \pm \text { SD } \\
\text { Not reported } \\
\text { ELIGIBILITY CRITERIA: participants with asthma who remained symptomatic on } \\
\text { ICS; age } 15-60 \text { years; history of EIB } \\
\text { EXCLUSION CRITERIA: not reported }\end{array}$ \\
\hline Interventions & $\begin{array}{l}\text { LTRA + ICS versus LABA + ICS (stable dose of ICS) } \\
\text { DURATION } \\
\text { Intervention period: } 4 \text { weeks } \\
\text { INTERVENTION GROUP } 1 \\
\text { LTRA: montelukast @ } 10 \mathrm{mg} / \text { day p.o.+ FP } 125 \mu \mathrm{g} \text { one puff bid, via inhalation } \\
\text { INTERVENTION GROUP } 2 \\
\text { LABA: salmeterol } 50 \mu \mathrm{g} \text { bid, via MDI + montelukast placebo + ICS = FP } 125 \mu \mathrm{g} \text { one } \\
\text { puff bid, via inhalation (separate inhalers) } \\
\text { CO-TREATMENT } \\
\text { Not reported }\end{array}$ \\
\hline Outcomes & $\begin{array}{l}\text { INTENTION-TO-TREAT ANALYSES: outcomes used at endpoint or } 4 \text { weeks } \\
\text { PULMONARY FUNCTION TESTS } \\
\text { Challenge FEV1 \% predicted; change in FEV1 \% predicted; rescue bronchodilation } \\
\text { SYMPTOM SCORES } \\
\text { Not reported } \\
\text { EXACERBATIONS } \\
\text { Not reported } \\
\text { FUNCTIONAL STATUS } \\
\text { Not reported } \\
\text { INFLAMMATORY MARKERS } \\
\text { Not reported } \\
\text { ADVERSE EFFECTS } \\
\text { Not reported } \\
\text { WITHDRAWALS } \\
\text { Due to adverse events: not reported } \\
\text { Due to poor control: not reported } \\
\text { Overall: reported } \\
\text { Primary outcome not identified }\end{array}$ \\
\hline Notes & $\begin{array}{l}\text { Unpublished: conference abstract } \\
\text { Funded by Merck } \\
\text { User-defined number: } 4 \text { weeks } \\
\text { No data could be used for aggregation }\end{array}$ \\
\hline
\end{tabular}

\section{Risk of bias}

Bias

Authors' judgement

Support for judgement

Addition to inhaled corticosteroids of long-acting beta2-agonists versus anti-leukotrienes for chronic asthma (Review)

Copyright (C) 201 I The Cochrane Collaboration. Published by John Wiley \& Sons, Ltd. 


\section{Hendeles 2004 (Continued)}

\begin{tabular}{l|l|l}
\hline $\begin{array}{l}\text { Random sequence generation (selection } \\
\text { bias) }\end{array}$ & Unclear risk & $\begin{array}{l}\text { Described as randomised; other informa- } \\
\text { tion not available }\end{array}$ \\
\hline $\begin{array}{l}\text { Allocation concealment (selection bias) } \\
\begin{array}{l}\text { Blinding (performance bias and detection } \\
\text { bias) } \\
\text { All outcomes }\end{array}\end{array}$ & Unclear risk & Information not available \\
\hline $\begin{array}{l}\text { Incomplete outcome data (attrition bias) } \\
\text { Exacerbations }\end{array}$ & Unclear risk & Information not available \\
\hline $\begin{array}{l}\text { Selective reporting (reporting bias) } \\
\text { Other bias }\end{array}$ & Unclear risk & Information not available \\
\hline
\end{tabular}

\section{Ilowite 2004}

Methods

Participants
Parallel-group study, multicentre trial (132 centres in USA for 48 weeks)

INADEQUATELY controlled participants on inhaled glucocorticoids at baseline BASELINE INHALED STEROID DOSAGE: $220 \mu \mathrm{g}$ of ICS per day RANDOMISED $=1473$

LTRA: 743

LABA: 730

WITHDRAWALS:

LTRA: $128 / 743$

LABA: $113 / 730$

AGE in years: mean $\pm S D$

LTRA: 39.0 (range 14-73)

LABA: 38.1 (range 15-70)

GENDER (\% male)

LTRA: $41.2 \%$

LABA: $37.5 \%$

SEVERITY

Moderate-to-severe persistent asthma

BASELINE FEV1 (\% pred)

LTRA: $74.3 \pm($ SD 11.5)

LABA: $74.3 \pm($ SD 11.7)

ALLERGEN TRIGGERS

Not reported

ALLERGIC RHINITIS

Not reported

ASTHMA DURATION in years

NS

ELIGIBILITY CRITERIA: age 15-65 years; asthma for $\geq 1$ year; ICS use daily for at 


\begin{tabular}{|c|c|}
\hline & $\begin{array}{l}\text { least } 8 \text { weeks prior to first visit; baseline FEV1 of } 50 \text { to } 90 \% \text { of predicted } \\
\geq 12 \% \text { change in FEV } 1 \text { after albuterol, and, in the } 14 \text { days prior to randomisation one } \\
\text { or more of the following: } \\
\text { 1. asthma symptom that required the use of } ß 2 \text {-agonist medication on average once } \\
\text { per day } \\
\text { 2. minimum biweekly daytime symptom score of } 56 \text { for a } 14 \text {-day period) } \\
\text { EXCLUSION CRITERIA: emergency department visit in }<1 \text { month; admission for } \\
\text { asthma in }<3 \text { months; upper respiratory infection in }<3 \text { weeks of } 1 \text { st visit or during } \\
\text { run-in; pregnant or lactating women; use of LABA within } 1 \text { month prior to visit } 1 \text {; } \\
\text { use }<1 \text { month of oral, intravenous, intramuscular, or intra-articular corticosteroids; use } \\
<2 \text { weeks of leukotriene antagonist, cromolyn, or nedocromil, use of theophylline in } \\
<1 \text { week, use in }<2 \text { weeks of oral or inhaled long-acting } \beta_{2} \text {-agonists or inhaled anti- } \\
\text { cholinergics } \\
\text { SETTING: not described }\end{array}$ \\
\hline Interventions & $\begin{array}{l}\text { LTRA + ICS versus LABA + ICS (stable dose of ICS) } \\
\text { DURATION: } \\
\text { Run-in period: } 2 \text { weeks } \\
\text { Intervention period: } 48 \text { weeks } \\
\text { INTERVENTION GROUP } 1 \\
\text { LTRA: montelukast } 10 \mathrm{mg} \text { once daily + fluticasone } 125 \mu \mathrm{g} \text { bid via MDI } \\
\text { INTERVENTION GROUP } 2 \\
\text { LABA: salmeterol } 50 \mu \mathrm{g} \text { bid, via MDI + fluticasone } 125 \mu \mathrm{g} \text { bid via MDI } \\
2 \text { inhalers used for combination therapy } \\
\text { CO-TREATMENT: not specified }\end{array}$ \\
\hline Outcomes & $\begin{array}{l}\text { INTENTION-TO-TREAT ANALYSES for patients who received at least one dose of } \\
\text { medication } \\
\text { Outcomes used at endpoint } \\
\text { PULMONARY FUNCTION TESTS: } \\
{ }^{* *} \text { Change from baseline in AM PEFR; change from baseline in PM PEFR; change from } \\
\text { baseline in FEV1 } \\
\text { SYMPTOM SCORES: } \\
\text { Change from baseline DAYTIME symptom scores; change from baseline NIGHTTIME } \\
\text { symptom scores } \\
\text { EXACERBATIONS } \\
\text { Exacerbations requiring systemic steroids } \\
\text { FUNCTIONAL STATUS } \\
\text { Change from baseline in mean OVERALL use of beta } 2 \text {-agonists (puffs/DAY); change } \\
\text { from baseline in mean DAYTIME use of beta } 2 \text {-agonists (puffs/DAY); change from base- } \\
\text { line in mean NIGHT-TIME use of beta2 } \text {-agonists (puffs/DAY); \% night-time awaken- } \\
\text { ings } \\
\text { INFLAMMATORY MARKERS } \\
\text { Not reported } \\
\text { ADVERSE EFFECTS } \\
\text { Drug related and non-drug related } \\
\text { WITHDRAWALS } \\
\text { Due to adverse effects reported } \\
\text { (** denotes trials primary outcome) }\end{array}$ \\
\hline
\end{tabular}


Ilowite 2004 (Continued)

\begin{tabular}{|c|c|c|}
\hline Notes & \multicolumn{2}{|c|}{$\begin{array}{l}\text { Unpublished data } \\
\text { Received full disclosure of unpublished data provided by Peter Polos, March } 2004 \\
\text { Funded by Merck \& Co } \\
\text { Confirmation with supportive documents received for methodology and data extraction } \\
\text { User-defined number: } 48 \text { weeks }\end{array}$} \\
\hline \multicolumn{3}{|l|}{ Risk of bias } \\
\hline Bias & Authors' judgement & Support for judgement \\
\hline $\begin{array}{l}\text { Random sequence generation (selection } \\
\text { bias) }\end{array}$ & Low risk & $\begin{array}{l}\text { Randomisation was determined by com- } \\
\text { puter generated allocation schedule (block } \\
\text { size } 4 \text { ) }\end{array}$ \\
\hline Allocation concealment (selection bias) & Low risk & Centralised, third party randomisation \\
\hline $\begin{array}{l}\text { Blinding (performance bias and detection } \\
\text { bias) } \\
\text { All outcomes }\end{array}$ & Low risk & Double-dummy \\
\hline $\begin{array}{l}\text { Incomplete outcome data (attrition bias) } \\
\text { Exacerbations }\end{array}$ & Unclear risk & ITT \\
\hline Selective reporting (reporting bias) & Low risk & $\begin{array}{l}\text { Data available for meta-analysis of primary } \\
\text { outcome }\end{array}$ \\
\hline Other bias & Low risk & \\
\hline
\end{tabular}

Lemanske 2010

\begin{tabular}{ll}
\hline Methods & Crossover study, multicentre study in USA \\
\hline Participants & INADEQUATELY controlled children on inhaled corticosteroids at baseline \\
& BASELINE INHALED STEROID DOSAGE: $100 \mu$ g FP ICS per day during run-in \\
RANDOMISED: 182 \\
WITHDRAWALS: \\
25 \\
AGE in years: mean \pm SD \\
$11 \pm 3$ \\
GENDER (\% male) \\
68\% \\
SEVERITY: \\
Mild-to-moderate asthma \\
BASELINE FEV1 $\%$ pred) \\
98\% \\
ALLERGEN TRIGGERS: \\
+ve aeroallergen test $77 \%$ \\
+ve perennial allergen test $70 \%$ \\
\end{tabular}




\begin{tabular}{|c|c|}
\hline & $\begin{array}{l}\text { ALLERGIC RHINITIS } \\
\text { Not reported } \\
\text { ASTHMA DURATION } \\
7 \text { years } \\
\text { ELIGIBILITY CRITERIA: age } 6 \text { to } 17 \text { years; physician diagnosed mild to moderate } \\
\text { asthma, based on NAEPP criteria; FEV1 predicted }>60 \% \text {; increase in FEV1 >12\% } \\
\text { predicted or PC20 } 12.5 \mathrm{mg} / \mathrm{mL} \text { or less } \\
\text { During run-in children had to exhibit uncontrolled asthma, defined as one or more of: } \\
\text { 1. diary-reported symptoms (coughing rated as moderate or severe or wheezing rated } \\
\text { as mild, moderate, or severe) } \\
\text { 2. rescue use of reliever medication (two or more puffs per day, or } \\
\text { 3. peak flows under } 80 \% \text { predicted } \\
\text { EXCLUSION CRITERIA: corticosteroid treatment within } 2 \text { weeks (unless ingested } \\
\text { nasally in which case at discretion of investigator; current or prior use of medications } \\
\text { known to interact with corticosteroids; more than three hospitalizations for asthma in the } \\
\text { past year; lung disease other than asthma; significant medical illness other than asthma; } \\
\text { history of cataracts, glaucoma, or medical disorder associated with adverse effects related } \\
\text { to corticosteroids; uncontrolled gastroesophageal reflux symptoms; significant asthma } \\
\text { exacerbation within } 2 \text { weeks of Visit } 1 \text { or more than } 5 \text { courses of systemic corticosteroids } \\
\text { in the past year; life-threatening asthma exacerbation requiring intubation, mechanical } \\
\text { ventilation, or resulting in a hypoxic seizure in last } 5 \text { years; adverse reactions to ICS, } \\
\text { LTRA, or LABA preparations; hyposensitization therapy other than an established main- } \\
\text { tenance regimen (continuous regimen for }>3 \text { months); pregnancy or lactation; failure to } \\
\text { practice abstinence or use of an acceptable birth control if of child-bearing potential; in- } \\
\text { ability to perform study procedures; refusal to consent to a genotype evaluation; inability } \\
\text { to ingest the study drug; evidence that the family may be unreliable or nonadherent, or } \\
\text { may move from the clinical center area before trial completion } \\
\text { SETTING: not described }\end{array}$ \\
\hline Interventions & $\begin{array}{l}\text { LTRA + ICS versus LABA + ICS (stable dose of ICS) } \\
\text { DURATION: } \\
\text { Run-in period: } 2-8 \text { weeks } \\
\text { Intervention period: } 48 \text { weeks ( } 3 \text { x } 16 \text { weeks) } \\
\text { INTERVENTION GROUP } 1 \\
\text { LTRA: montelukast } 5 \text { or } 10 \mathrm{mg} \text { once daily + fluticasone } 100 \mu \mathrm{g} \text { bid via DPI } \\
\text { INTERVENTION GROUP } 2 \\
\text { LABA: salmeterol } 50 \mu \mathrm{g} \text { bid, via MDI + fluticasone } 100 \mu \mathrm{g} \text { bid via DPI } \\
1 \text { inhaler used for combination therapy } \\
\text { CO-TREATMENT: not specified }\end{array}$ \\
\hline Outcomes & $\begin{array}{l}\text { INTENTION-TO-TREAT ANALYSES No (completers analysed) } \\
\text { PULMONARY FUNCTION TESTS: } \\
\text { Collected as part of a composite outcome (differential response**): FEV1 } \\
\text { SYMPTOM SCORES: } \\
\text { Collected as part of a composite outcome (differential response**): symptom-free days } \\
\text { EXACERBATIONS } \\
\left.\text { Collected as part of a composite outcome (differential response }{ }^{* *}\right) \text { : exacerbations requir- } \\
\text { ing systemic steroids } \\
\text { FUNCTIONAL STATUS }\end{array}$ \\
\hline
\end{tabular}


Lemanske 2010 (Continued)

\begin{tabular}{ll} 
& Quality of life (AQLQ) \\
INFLAMMATORY MARKERS: \\
Collected \\
ADVERSE EFFECTS \\
Drug related and non-drug related \\
WITHDRAWALS \\
Stated \\
$(*$ denotes trials primary outcome) \\
\hline Notes & $\begin{array}{l}\text { Full-text article } \\
\text { Funded by National Heart, Lung, and Blood Institute (HL064307, HL064288, } \\
\text { HL064295, HL064287, HL064305, and HL064313), the National Institute of Allergy } \\
\text { and Infectious Diseases (T32AI007635), and the Clinical Translational Science Award } \\
\text { program of the National Center for Research Resources (UL1-RR025011 [Wisconsin], } \\
\text { UL1-RR025780 [Colorado], and UL1-RR024992 [St. Louis]) } \\
\text { Confirmation of data: not obtained } \\
\text { User-defined number: 16 weeks }\end{array}$ \\
\hline
\end{tabular}

Risk of bias

\begin{tabular}{|c|c|c|}
\hline Bias & Authors' judgement & Support for judgement \\
\hline $\begin{array}{l}\text { Random sequence generation (selection } \\
\text { bias) }\end{array}$ & Low risk & $\begin{array}{l}\text { Computer generated randomisation sched- } \\
\text { ule: } \\
\text { 'The pattern of treatment assignment will } \\
\text { utilize the complete set of orthogonal Latin } \\
\text { squares...' }\end{array}$ \\
\hline Allocation concealment (selection bias) & Low risk & $\begin{array}{l}\text { Centralised randomisation. Investigators } \\
\text { dialled into server requesting assignment, } \\
\text { and received a packet number which related } \\
\text { to a medication }\end{array}$ \\
\hline $\begin{array}{l}\text { Blinding (performance bias and detection } \\
\text { bias) } \\
\text { All outcomes }\end{array}$ & Low risk & $\begin{array}{l}\text { 'The drug assignments were masked with } \\
\text { the use of placebo tablets and dummy disk } \\
\text { devices that discharged powder without the } \\
\text { active drug' } \\
\text { '...investigators and the children, along } \\
\text { with their caregivers, will not know which } \\
\text { treatment is being received during each } \\
\text { treatment period.' }\end{array}$ \\
\hline $\begin{array}{l}\text { Incomplete outcome data (attrition bias) } \\
\text { Exacerbations }\end{array}$ & High risk & Completers analysed (crossover design) \\
\hline Selective reporting (reporting bias) & Low risk & Primary outcome analysed as events \\
\hline Other bias & Low risk & \\
\hline
\end{tabular}


Nelson 2000

\begin{tabular}{|c|c|}
\hline Methods & Parallel-group study, multicentre trial (39 centres) \\
\hline Participants & 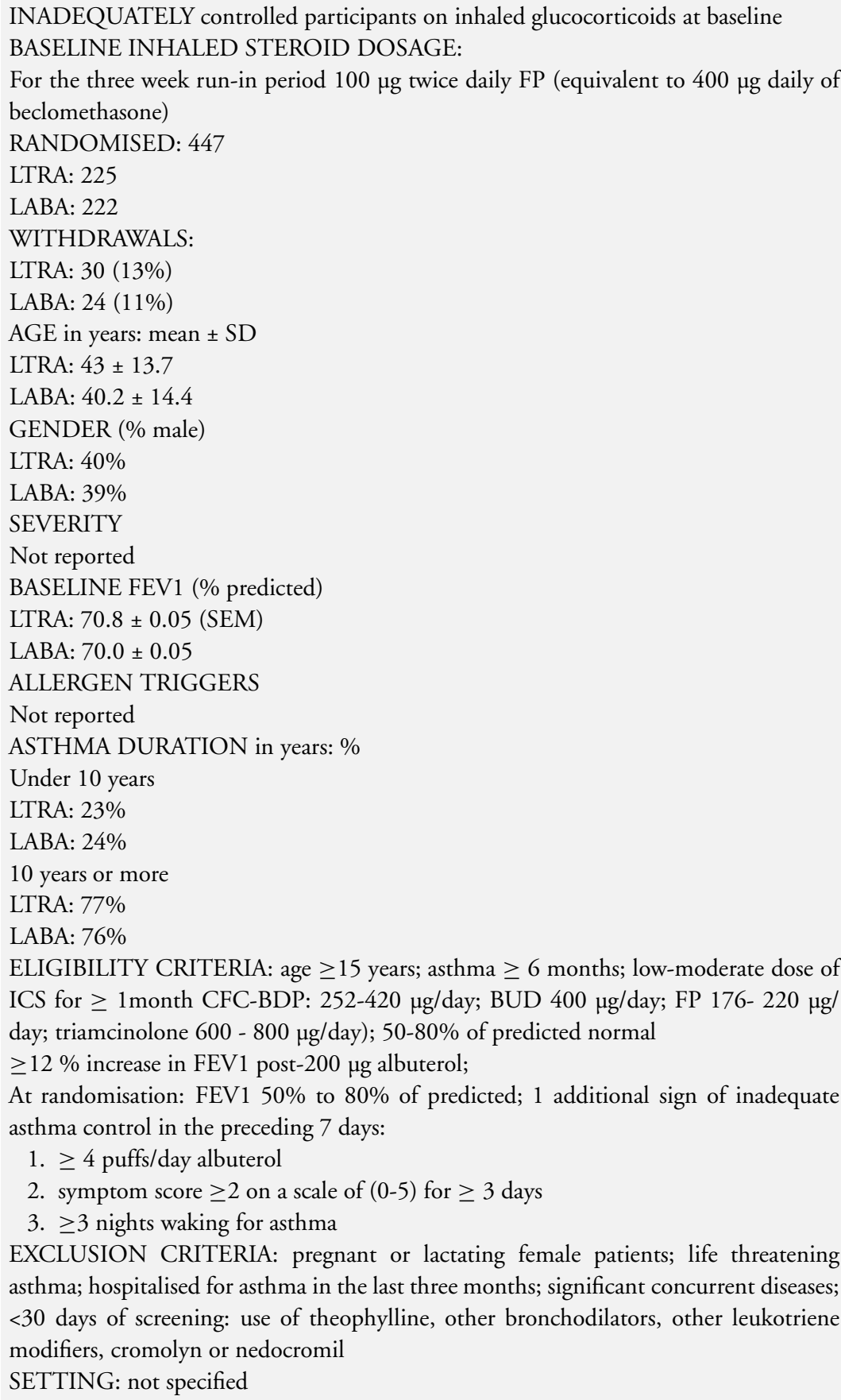 \\
\hline Interventions & $\begin{array}{l}\text { LTRA + ICS versus LABA + ICS (stable dose of ICS) } \\
\text { DURATION: } \\
\text { Run-in period: } 3 \text { weeks }\end{array}$ \\
\hline
\end{tabular}


Nelson 2000 (Continued)

\begin{tabular}{|c|c|c|}
\hline & \multicolumn{2}{|c|}{$\begin{array}{l}\text { Intervention period: } 12 \text { weeks } \\
\text { INTERVENTION GROUP } 1 \\
\text { LTRA: oral montelukast } 10 \mathrm{mg} \text { once daily + ICS = FP } 100 \mu \mathrm{g} \text { twice daily, via diskus } \\
\text { INTERVENTION GROUP } 2 \\
\text { LABA: salmeterol } 50 \mu \mathrm{g} \text { twice daily, via Diskus + ICS = FP } 100 \mu \mathrm{g} \text { twice daily, via Diskus } \\
1 \text { inhaler used for combination therapy } \\
\text { CO-TREATMENT: none }\end{array}$} \\
\hline Outcomes & \multicolumn{2}{|c|}{$\begin{array}{l}\text { Modified INTENTION-TO-TREAT ANALYSES } \\
\text { Outcomes used at endpoint for exacerbations and withdrawals only (not available for } \\
\text { continuous values) } \\
\text { PULMONARY FUNCTION TESTS } \\
\text { Change from baseline FEV1; change from baseline in AM PEFR; change from baseline } \\
\text { in PM PEFR } \\
\text { SYMPTOM SCORES } \\
\text { Change from baseline OVERALL symptom scores; change from baseline in nighttime } \\
\text { awakenings; change in symptom-free days } \\
\text { EXACERBATIONS } \\
\text { Exacerbations requiring hospital admission; exacerbations requiring systemic steroids } \\
\text { (data provided) } \\
\text { FUNCTIONAL STATUS } \\
\text { Change from baseline in mean OVERALL use of } 32 \text {-agonists (puffs/DAY); change in } \\
\text { rescue-free days } \\
\text { INFLAMMATORY MARKERS } \\
\text { Not reported } \\
\text { ADVERSE EFFECTS } \\
\text { Included oral candidiasis, sore throat, hoarseness, headache } \\
\text { WITHDRAWALS } \\
\text { Due to adverse effects } \\
\text { Due to poor control } \\
\text { Overall } \\
\text { (reported) } \\
\text { (** denotes primary outcome) }\end{array}$} \\
\hline Notes & \multicolumn{2}{|c|}{$\begin{array}{l}\text { Full-text report } \\
\text { Received additional unpublished data provided by Karen Richardson, GSK (July 2003) } \\
\text { Funded by Glaxo Wellcome, study SAS } 40018 \\
\text { Confirmation of methodology and data extraction received } \\
\text { User-defined order: } 12 \text { weeks }\end{array}$} \\
\hline \multicolumn{3}{|l|}{ Risk of bias } \\
\hline Bias & Authors' judgement & Support for judgement \\
\hline $\begin{array}{l}\text { Random sequence generation (selection } \\
\text { bias) }\end{array}$ & Low risk & $\begin{array}{l}\text { Computer generated randomisation sched- } \\
\text { ule }\end{array}$ \\
\hline Allocation concealment (selection bias) & Low risk & $\begin{array}{l}\text { Numbered coded inhaler/pills supplied by } \\
\text { pharmacy }\end{array}$ \\
\hline
\end{tabular}


Nelson 2000 (Continued)

\begin{tabular}{|c|c|c|}
\hline $\begin{array}{l}\text { Blinding (performance bias and detection } \\
\text { bias) } \\
\text { All outcomes }\end{array}$ & Low risk & Double-dummy \\
\hline $\begin{array}{l}\text { Incomplete outcome data (attrition bias) } \\
\text { Exacerbations }\end{array}$ & Unclear risk & $\begin{array}{l}\text { 'The primary population for the analyses } \\
\text { of demographic/baseline characteristics, ef- } \\
\text { ficacy and safety was the Intent-to-Treat } \\
\text { (ITT Population), which consisted of all } \\
\text { subjects who were randomised to receive } \\
\text { study drug.' }\end{array}$ \\
\hline Selective reporting (reporting bias) & Low risk & Data available for primary outcome. \\
\hline Other bias & Low risk & \\
\hline Nelson 2001 & & \\
\hline Methods & \multicolumn{2}{|l|}{ Parallel-group, multicentre trial ( 54 centres) } \\
\hline Participants & \multicolumn{2}{|c|}{$\begin{array}{l}\text { INADEQUATELY controlled adolescent and adult participants on inhaled glucocorti- } \\
\text { coids at baseline } \\
\text { BASELINE INHALED STEROID DOSAGE: } \\
\text { Not described } \\
\text { RANDOMISED = } 429 \\
\text { LTRA: } 215 \\
\text { LABA: } 214 \\
\text { WITHDRAWALS: } \\
\text { LTRA: } 18 \text { (8\%) } \\
\text { LABA: } 12(6 \%) \\
\text { AGE in years: mean } \pm \text { SD } \\
\text { LTRA: } 39.3 \pm 13.20 \\
\text { LABA: } 40.9 \pm 13.17 \\
\text { GENDER (\% male) } \\
\text { LTRA: } 44 \% \\
\text { LABA: } 44 \% \\
\text { SEVERITY } \\
\text { Not described } \\
\text { BASELINE FEV1 } \% \text { predicted) } \\
\text { LTRA: } 65.86 \pm 0.58 \text { (SEM) } \\
\text { LABA: } 66.62 \pm 0.58 \\
\text { ALLERGEN TRIGGERS } \\
\text { Not reported } \\
\text { ASTHMA DURATION in years: } \% \\
\text { Under } 10 \text { years } \\
\text { LTRA: } 24 \% \\
\text { LABA: } 24 \% \\
10 \text { years or over } \\
\text { LTRA: } 76 \%\end{array}$} \\
\hline
\end{tabular}




\begin{tabular}{|c|c|}
\hline & 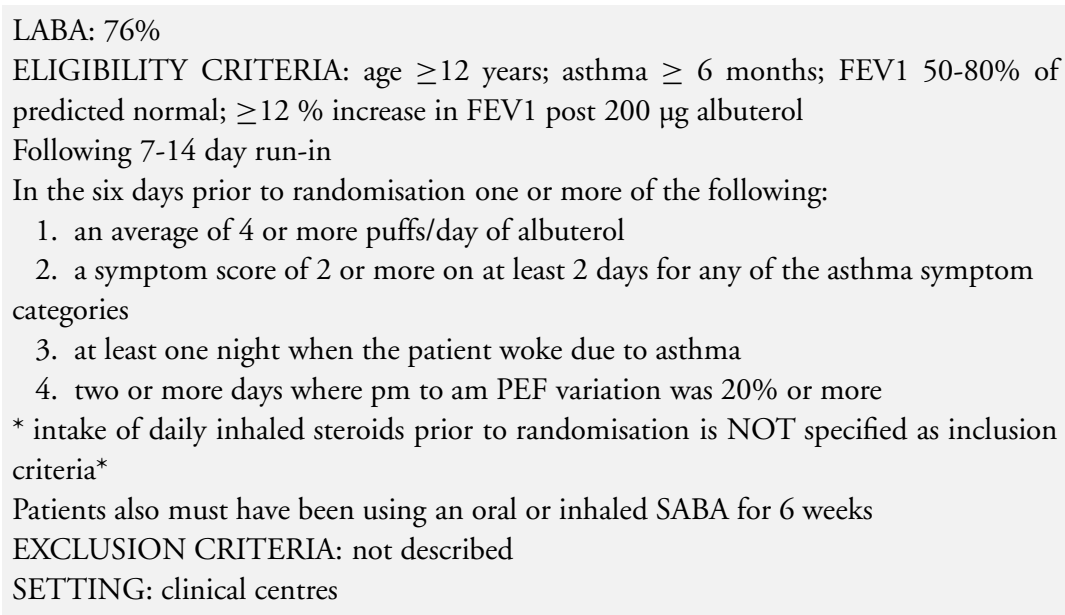 \\
\hline Interventions & $\begin{array}{l}\text { LTRA + ICS versus LABA + ICS (stable dose of ICS) } \\
\text { DURATION: } \\
\text { Run-in period: } 1-2 \text { weeks } \\
\text { Intervention period: } 4 \text { weeks } \\
\text { INTERVENTION GROUP } 1 \\
\text { LTRA: zafirlukast } 20 \text { mg twice daily + ICS: constant dose of existing ICS medication } \\
\text { INTERVENTION GROUP } 2 \\
\text { LABA: salmeterol } 42 \mu \mathrm{g}, 2 \text { puffs twice daily via MDI + ICS = constant dose of existing } \\
\text { ICS medication } \\
2 \text { inhalers used for combination therapy } \\
\text { CO-TREATMENT: } \\
\text { Theophylline or other medications that could potentially interact with study treatment } \\
\text { not allowed; Albuterol inhalers provided for use on an as needed basis but all other } \\
\text { bronchodilators not permitted; antihistamines, nasal decongestants and intranasal med- } \\
\text { ications for rhinitis were permitted }\end{array}$ \\
\hline Outcomes & $\begin{array}{l}\text { INTENTION-TO-TREAT ANALYSES: outcomes used at endpoint } \\
\text { PULMONARY FUNCTION TESTS } \\
\text { Change from baseline FEV1; }{ }^{* *} \text { change from baseline in am PEFR; change from baseline } \\
\text { in PM PEFR; change in PEF variability } \\
\text { SYMPTOM SCORES } \\
\text { Change from baseline DAYTIME symptom scores; change from baseline NIGHT- } \\
\text { TIME symptom scores; change in symptom-free days; patient satisfaction } \\
\text { EXACERBATIONS } \\
\text { Exacerbations requiring systemic steroids; exacerbations defined as any worsening of } \\
\text { asthma symptoms requiring a change in the patients asthma therapy other than increased } \\
\text { use of supplemental albuterol. Patients who experienced an exacerbation were withdrawn } \\
\text { from the study } \\
\text { FUNCTIONAL STATUS } \\
\text { Change from baseline in mean DAYTIME use of B2-agonists (/DAY); change from } \\
\text { baseline in mean NIGHT-TIME use of } 32 \text {-agonists (/DAY); change in rescue-free days; } \\
\text { change/absolute in rescue-free nights; change in quality of life; change in night-time } \\
\text { awakenings }\end{array}$ \\
\hline
\end{tabular}


Nelson 2001 (Continued)

\begin{tabular}{|c|c|}
\hline & $\begin{array}{l}\text { INFLAMMATORY MARKERS } \\
\text { Not reported } \\
\text { ADVERSE EFFECTS } \\
\text { Upper respiratory tract infection, headache, nausea } \\
\text { WITHDRAWALS } \\
\text { Due to adverse effects } \\
\text { Due to poor control } \\
\text { Overall } \\
\text { (reported) } \\
\left({ }^{* *} \text { denotes primary outcome) }\right.\end{array}$ \\
\hline Notes & $\begin{array}{l}\text { Full-text report } \\
\text { Received additional unpublished data provided by Karen Richardson, GSK } \\
\text { Funded by Glaxo Wellcome, protocols SLGA5024 \& SLGA5025 } \\
\text { Confirmation of methodology and data extraction received } \\
\text { User-defined order: } 4 \text { weeks }\end{array}$ \\
\hline
\end{tabular}

\section{Risk of bias}

\begin{tabular}{|c|c|c|}
\hline Bias & Authors' judgement & Support for judgement \\
\hline $\begin{array}{l}\text { Random sequence generation (selection } \\
\text { bias) }\end{array}$ & Low risk & See Appendix 1 \\
\hline Allocation concealment (selection bias) & Low risk & See Appendix 1 \\
\hline $\begin{array}{l}\text { Blinding (performance bias and detection } \\
\text { bias) } \\
\text { All outcomes }\end{array}$ & Low risk & Double-dummy \\
\hline $\begin{array}{l}\text { Incomplete outcome data (attrition bias) } \\
\text { Exacerbations }\end{array}$ & Unclear risk & $\begin{array}{l}\text { 'The ITT population included all subjects } \\
\text { who were randomized to study drug.' }\end{array}$ \\
\hline Selective reporting (reporting bias) & Low risk & Data available for primary outcome \\
\hline Other bias & Low risk & \\
\hline
\end{tabular}

\section{Nsouli 2001}

\begin{tabular}{ll} 
Methods & Unclear if parallel-group or crossover \\
\hline Participants & INADEQUATELY controlled participants on inhaled glucocorticoids at baseline \\
& BASELINE INHALED STEROID DOSAGE: \\
FP 100-300 or CFC BDP 200-550 or BUD 200-400 or flunisolide 500-1000 or triam- \\
cinolone 400-1000 \\
RANDOMISED: 30 \\
LTRA: unknown \\
LABA: unknown
\end{tabular}


Nsouli 2001 (Continued)

\begin{tabular}{|c|c|}
\hline & $\begin{array}{l}\text { WITHDRAWALS } \\
\text { Not described } \\
\text { AGE in years: mean } \pm \text { SD } \\
\text { Not described } \\
\text { GENDER (\% male) } \\
\text { Not described } \\
\text { SEVERITY } \\
\text { Not described } \\
\text { BASELINE FEV1 (L OR \% PRED) } \\
\text { Not described } \\
\text { ALLERGEN TRIGGERS } \\
\text { Not described } \\
\text { ASTHMA DURATION in years: mean } \pm \text { SD } \\
\text { Not described } \\
\text { ELIGIBILITY CRITERIA } \\
\text { Not described } \\
\text { EXCLUSION CRITERIA } \\
\text { Not described } \\
\text { SETTING } \\
\text { Not described }\end{array}$ \\
\hline Interventions & $\begin{array}{l}\text { LTRA + ICS versus LABA + ICS (stable dose of ICS) } \\
\text { DURATION: } \\
\text { Run-in period: not described } \\
\text { Intervention period: } 8 \text { weeks } \\
\text { INTERVENTION GROUP } 1 \\
\text { LTRA: montelukast } 10 \mathrm{mg} \text { QD pm + ICS (low dose ICS) } \\
\text { INTERVENTION GROUP } 2 \\
\text { LABA: salmeterol } 50 \mu \mathrm{g} \text { BID + ICS (low dose ICS) } \\
2 \text { inhalers used for combination therapy } \\
\text { CO-TREATMENT } \\
\text { Not reported }\end{array}$ \\
\hline Outcomes & $\begin{array}{l}\text { ANALYSES: not reported } \\
\text { PULMONARY FUNCTION TESTS } \\
\text { FEV1 and FEF25-75 } \\
\text { SYMPTOM SCORES } \\
\text { None described } \\
\text { EXACERBATIONS } \\
\text { Not described } \\
\text { FUNCTIONAL STATUS } \\
\text { Quality of life } \\
\text { INFLAMMATORY MARKERS } \\
\text { Not described } \\
\text { ADVERSE EFFECTS } \\
\text { Not described } \\
\text { WITHDRAWALS } \\
\text { Not described }\end{array}$ \\
\hline
\end{tabular}


Nsouli 2001 (Continued)

\begin{tabular}{|c|c|c|}
\hline Notes & \multicolumn{2}{|c|}{$\begin{array}{l}\text { Abstract } \\
\text { Funding of study unknown } \\
\text { Confirmation of methodology and data extraction not obtained } \\
\text { User-defined order: } 8 \text { weeks }\end{array}$} \\
\hline \multicolumn{3}{|l|}{ Risk of bias } \\
\hline Bias & Authors' judgement & Support for judgement \\
\hline $\begin{array}{l}\text { Random sequence generation (selection } \\
\text { bias) }\end{array}$ & Unclear risk & $\begin{array}{l}\text { Described as randomised; other information not } \\
\text { available }\end{array}$ \\
\hline Allocation concealment (selection bias) & Unclear risk & Information not available \\
\hline $\begin{array}{l}\text { Blinding (performance bias and detection } \\
\text { bias) } \\
\text { All outcomes }\end{array}$ & Unclear risk & Information not available \\
\hline $\begin{array}{l}\text { Incomplete outcome data (attrition bias) } \\
\text { Exacerbations }\end{array}$ & Unclear risk & Information not available \\
\hline Selective reporting (reporting bias) & Unclear risk & Cannot establish this reliably \\
\hline Other bias & Unclear risk & Cannot establish this reliably \\
\hline
\end{tabular}

Pavord 2007

\begin{tabular}{ll} 
Methods & Parallel-group, multicentre study in the UK \\
\hline Participants & $\begin{array}{l}\text { BASELINE INHALED STEROID DOSE: up to } 400 \mu \mathrm{g} \text { (which BDP or HFA) BDP } \\
\text { equivalent } \\
\text { N SCREENED: } 132 \\
\text { N RANDOMISED: } 66 \\
\text { N COMPLETED: } 54 \\
\text { M }=34 \\
\text { F }=32 \\
\text { MEAN AGE: } 35 \\
\text { BASELINE DETAILS: PEF } 417 \text { L/min; FEV1 predicted } 76 \% \\
\text { INCLUSION CRITERIA: } 18 \text { to } 50 \text { years, non-smokers, receiving a stable dose of up } \\
\text { to } 400 \mu \text { g of beclomethasone dipropionate (presumed CFC-BDP equivalent) a day or } \\
\text { equivalent ICS, requiring further therapy; likelihood of compliance with the protocol } \\
\text { requirements and ability to use an Accuhaler and mini-Wright peak flow meter. Post-run } \\
\text { in: baseline FEV1 } 61 \text { to } 85 \% \text { predicted; PC20 }<8 \text { mg/ml with methacholine challenge; } \\
\text { at least one of: diary card recording of symptoms on }>4 \text { of the last seven days of the run- } \\
\text { in period; recorded use of relief medication on }>2 \text { different days during the last seven } \\
\text { days of the run-in period; period variation in PEF of }>10 \% \text { over last seven days of run } \\
\text { in } \\
\text { EXCLUSION: additional medication other than ICS, SABA or OCS in previous } 3\end{array}$
\end{tabular}


Pavord 2007 (Continued)

months; acute respiratory infection/exacerbation of asthma within 4 weeks of screening; recent or significant smoking history; pregnancy/lactation; inadequate contraceptive methods in women of child-bearing age

\begin{tabular}{ll}
\hline Interventions & 1. Combination fluticasone/salmeterol 100/50 $\mu$ B.I.D \\
& 2. Fluticasone 100mcg B.I.D. plus montelukast 10mg O.D. \\
& RUN-IN PERIOD: 2 weeks \\
& TREATMENT PERIOD: 12 weeks \\
\hline Outcomes & INTENTION TO TREAT ANALYSES: no \\
& PULMONARY FUNCTION TEST: \\
& FEV1; am PEF; pm PEF \\
& SYMPTOMS: \\
& Percentages of symptom-free days and nights \\
& FUNCTIONAL STATUS: \\
& Rescue medication use \\
& INFLAMMATORY MARKERS: \\
& Neutrophils, eosinophils, macrophages, lymphocytes \\
\hline \multirow{2}{*}{ Notes } & \\
\hline
\end{tabular}

Risk of bias

\begin{tabular}{|c|c|c|}
\hline Bias & Authors' judgement & Support for judgement \\
\hline $\begin{array}{l}\text { Random sequence generation (selection } \\
\text { bias) }\end{array}$ & Low risk & $\begin{array}{l}\text { '...consecutively randomised according to } \\
\text { a } \\
\text { pre-defined randomisation list...' }\end{array}$ \\
\hline Allocation concealment (selection bias) & Low risk & $\begin{array}{l}\text { 'Treatment allocation was concealed from } \\
\text { the subject, pharmacist, and investigator.' }\end{array}$ \\
\hline $\begin{array}{l}\text { Blinding (performance bias and detection } \\
\text { bias) } \\
\text { All outcomes }\end{array}$ & Low risk & Double-dummy design employed \\
\hline $\begin{array}{l}\text { Incomplete outcome data (attrition bias) } \\
\text { Exacerbations }\end{array}$ & Unclear risk & $\begin{array}{l}\text { 'All summaries and analyses are for the in- } \\
\text { tention-to-treat population (all subjects re- } \\
\text { ceiving at least one dose of the study drug) } \\
\text {. No imputations were performed for miss- } \\
\text { ing data. Therefore if data were missing for } \\
\text { either baseline or one of the time points, it } \\
\text { was not possible to calculate a change from } \\
\text { baseline. However, all available data have } \\
\text { been used for relevant summaries.' } \\
\text { Some imbalance between the treatment } \\
\text { groups in terms of withdrawal, although } \\
\text { denominators for lung function outcomes } \\
\text { show N randomised }\end{array}$ \\
\hline
\end{tabular}


Pavord 2007 (Continued)

\begin{tabular}{l|l|l} 
Selective reporting (reporting bias) & Low risk & $\begin{array}{l}\text { The outcomes identified as being those of } \\
\text { interest were presented in the article. Data } \\
\text { on exacerbations were not identified as be- } \\
\text { ing an outcome of interest to the investiga- } \\
\text { tors }\end{array}$ \\
\hline Other bias & Low risk & \\
\hline
\end{tabular}

Ringdal 2003

Methods

Participants
Parallel-group, multicentre trial (114 centres in 19 countries)

INADEQUATELY controlled participants on 'moderate or high doses' of inhaled glucocorticoids at baseline

\section{BASELINE INHALED STEROID DOSAGE:}

$800 \mu \mathrm{g}$ or more of beclomethasone-equivalent/day (moderate or high dose)

RANDOMISED: 806, 81 excluded due to not meeting eligibility criteria for randomisation

LTRA: 369

LABA: 356

WITHDRAWALS:

LTRA: $37(10 \%)$

LABA: $19(5 \%)$

AGE in years: mean $\pm S D$

LTRA: 43 (14-79)

LABA: $43(15-75)$

GENDER (\% male)

LTRA: $45 \%$

LABA: $46 \%$

SEVERITY: MODERATE PERSISTENT asthma BASELINE FEV1 (\% PRED)

LTRA: $74.3 \pm 16.1$

LABA: $75.8 \pm 15.3$

ALLERGEN TRIGGERS

Not described

ASTHMA DURATION in years: mean \pm SD

Not described

ELIGIBILITY CRITERIA: age $\geq 15$ years; moderate persistent asthma as per the ATS and NAEPP Report 2; using inhaled corticosteroids at moderate or high dose ( 400$1000 \mu \mathrm{g} /$ day of CFC-BDP, BUD or flunisolide; or 200-500 $\mu \mathrm{g}$ /day of FP) for at least 4 weeks; history of reversible airway obstruction; $\geq 15 \%$ change in FEV1 after $800 \mu \mathrm{g}$ of salbutamol;

At end of run-in: Mean PEF of $50 \%$ to $<85 \%$ of value in clinic after $400 \mu \mathrm{g}$ of salbutamol; cumulative symptom score of $\geq 8$ in past 7 days or $\geq 4$ of the last 7 days of run-in EXCLUSION CRITERIA: Recent change in asthma medication; respiratory tract infection or admission for asthma in $<4$ weeks; intake of oral, depot, or parenteral corticosteroids in $<4$ weeks or $\geq 2$ occasions in past 12 weeks; cigarette smoking $\geq 10$ pack 
Ringdal 2003 (Continued)

year; pregnancy or lactating women or those likely to become pregnant during study; FEV $1<50 \%$

Interventions
LTRA + ICS versus LABA + ICS (stable dose of ICS)
DURATION:
Run-in period: 4 weeks
Intervention period: 12 weeks plus a 2-week follow up
INTERVENTION GROUP 1
LTRA: montelukast $10 \mathrm{mg} /$ day + ICS: FP 100 ug twice daily, via diskus
INTERVENTION GROUP 2
LABA: salmeterol 50 ug bid + ICS: FP $100 \mu$ twice daily, via Diskus
1 inhaler used for combination therapy.
CO-TREATMENT:
Salbutamol provided for relief of symptoms, no other SABAs permitted
Other oral, parenteral or depot CS not allowed except where documented for treatment
of exacerbations. Other existing asthma treatment allowed at constant dose

Outcomes
INTENTION-TO-TREAT ANALYSES: yes, but excluding those who were incorrectly randomised because they failed major inclusion criteria; outcomes used at endpoint PULMONARY FUNCTION TESTS

Change from baseline in FEV1; ${ }^{*}$ change from baseline in am PEFR; change from baseline in pm PEFR

\section{SYMPTOM SCORES}

Change in total symptom score; \% change in symptom-free days and nights; patient satisfaction; physician assessment of effectiveness; compliance with study treatment EXACERBATIONS

Exacerbations requiring systemic steroids; exacerbations requiring hospital admission; exacerbations defined as MILD: deterioration in asthma requiring a clinically relevant increase in salbutamol use defined as more than 3 additional inhalations per 24 hour period with respect to baseline for more than 2 consecutive days. MODERATE: requiring oral CS and/or antibiotics. SEVERE: requiring hospitalisation FUNCTIONAL STATUS

$\%$ rescue-free days; \% change in use of rescue medication (puffs/day); \% symptom-free days

\section{INFLAMMATORY MARKERS}

Not reported

ADVERSE EFFECTS

Serious adverse events, headache, oral thrush

WITHDRAWALS

Due to adverse effects

Overall

(reported)

(** denotes primary outcome)

Full-text report

Received additional unpublished data provided by Karen Richardson, GSK

Funded by Glaxo SmithKline, study SAS40015

Confirmation of methodology and data extraction received

User-defined order: 12 weeks 
Ringdal 2003 (Continued)

\section{Risk of bias}

\begin{tabular}{|c|c|c|}
\hline Bias & Authors' judgement & Support for judgement \\
\hline $\begin{array}{l}\text { Random sequence generation (selection } \\
\text { bias) }\end{array}$ & Low risk & $\begin{array}{l}\text { Computer generated randomisation sched- } \\
\text { ule }\end{array}$ \\
\hline Allocation concealment (selection bias) & Low risk & $\begin{array}{l}\text { Numbered coded inhalers/pills supplied by } \\
\text { pharmacy }\end{array}$ \\
\hline $\begin{array}{l}\text { Blinding (performance bias and detection } \\
\text { bias) } \\
\text { All outcomes }\end{array}$ & Low risk & Double-dummy \\
\hline $\begin{array}{l}\text { Incomplete outcome data (attrition bias) } \\
\text { Exacerbations }\end{array}$ & Unclear risk & $\begin{array}{l}\text { 'The ITT population (SFC: } 404 \text { subjects; } \\
\text { FP+montelukast: } 401 \text { subjects), which in- } \\
\text { cluded all randomised subjects, was used } \\
\text { for adverse event and concurrent medi- } \\
\text { cation data. The modified ITT popula- } \\
\text { tion (SFC: } 356 \text { subjects; FP+montelukast: } \\
369 \text { subjects), which excluded randomised } \\
\text { subjects who did not receive treatment as } \\
\text { well as subjects who were incorrectly ran- } \\
\text { domised, was used for efficacy, demogra- } \\
\text { phy and baseline characteristics data.' }\end{array}$ \\
\hline Selective reporting (reporting bias) & Low risk & Data available for primary outcome \\
\hline Other bias & Low risk & \\
\hline
\end{tabular}

\section{SAM40030}

\begin{tabular}{ll}
\hline Methods & Parallel-group, multicentre trial \\
\hline Participants & INADEQUATELY controlled participants on inhaled glucocorticoids at baseline \\
& BASELINE INHALED STEROID DOSAGE: \\
$\leq 400 \mu \mathrm{g}$ of BDP/day or equivalent \\
RANDOMISED: 66 \\
LTRA: 33 \\
LABA: 33 \\
WITHDRAWALS: \\
LTRA: $4 / 33(12.12 \%)$ \\
LABA: $9 / 33(27.27 \%)$ \\
AGE in years: mean \pm SD \\
35 years \\
GENDER (\% male) \\
52\% \\
SEVERITY:
\end{tabular}


Mild-moderate

BASELINE FEV1 (\% pred)

$76 \%$

ALLERGEN TRIGGERS:

Not reported

ALLERGIC RHINITIS:

Not reported

ASTHMA DURATION in years

Not reported

ELIGIBILITY CRITERIA: age 18-50 years; confirmed diagnosis of asthma

-have received constant daily dose of up to $400 \mathrm{mcg}$ of inhaled CFC-BDP or equivalent in the last 4 weeks

During run-in period: FEV1 $61-85 \%$ of predicted; $\geq 20 \%$ fall in FEV1 on methacholine challenge; symptom score of $\geq 1$ on $4 / 7$ days; use of rescue $ß 2$-agonists on $\geq 2 / 7$ days; $\geq 10 \%$ period variation in PEFR over the last 7 days of run-in

EXCLUSION CRITERIA: intake of asthma medication other than inhaled steroids or short-acting beta 2 -agonists in the past 4 weeks; oral steroids in the past 3 months; respiratory infection within 4 weeks; hospital admission in past 12 months; evidence of underlying chronic lung disease; smoking history of 10 pack-years or more; pregnant or lactating women; other chronic diseases; use of LABA or LTRAs within 1 month prior to visit 1; known intolerance to study drugs or inhaled lactose

SETTING: not described

Interventions
LTRA + ICS versus LABA + ICS (stable dose of ICS)

\section{DURATION:}

Run-in period: not reported

Intervention period: 12 weeks

INTERVENTION GROUP 1

LTRA: montelukast $10 \mathrm{mg}$ die + fluticasone (Flixotide) 100 bid via MDI

INTERVENTION GROUP 2

LABA: salmeterol $50 \mu \mathrm{g}$ bid via MDI + fluticasone $100 \mu \mathrm{g}$ bid

(in single MDI: Seretide 50)

1 inhaler used for combination therapy

CO-TREATMENT: not specified

\section{Modified INTENTION-TO-TREAT ANALYSES}

Outcomes used at 12 weeks or endpoint

PULMONARY FUNCTION TESTS

Change from baseline in AM PEFR (L/min); change from baseline in PM PEFR (L/ min); change from baseline in FEV1 (L)

SYMPTOMS (reported as medians)

Change in symptom-free days; change in symptom-free nights

EXACERBATIONS REQUIRING SYSTEMIC STEROIDS

Not reported

FUNCTIONAL STATUS (reported as medians):

Change from baseline in mean DAYTIME use of 32 -agonists; change from baseline in mean NIGHT-TIME use of $B 2$-agonists; change in rescue-free days; change in nighttime awakenings

INFLAMMATORY MARKERS (reported as medians): 


\begin{tabular}{ll} 
& Sputum ${ }^{* *}$ eosinophils, neutrophils, total cell counts, C-LT, histamine, IL-8 \\
ADVERSE EFFECTS & Reported \\
WITHDRAWALS & Reported \\
& $\left({ }^{* *}\right.$ denotes primary outcome) \\
\hline Notes & Unpublished data \\
& $\begin{array}{l}\text { Received full disclosure of unpublished data provided by Karen Richardson, GSK (July } \\
\text { 2003) } \\
\text { Funded by GSK : study \#40030 } \\
\text { Confirmation with supportive documents received for methodology and data extraction } \\
\text { obtained from Karen Richardson, GSK, UK }\end{array}$ \\
\hline
\end{tabular}

\section{Risk of bias}

\begin{tabular}{l|l|l}
\hline Bias & Authors' judgement & Support for judgement \\
\hline $\begin{array}{l}\text { Random sequence generation (selection } \\
\text { bias) }\end{array}$ & Low risk & Computer generated randomisation schedule \\
\hline $\begin{array}{l}\text { Allocation concealment (selection bias) } \\
\text { Blinding (performance bias and detection } \\
\text { bias) } \\
\text { All outcomes }\end{array}$ & Low risk & Opaque consecutive envelopes containing assessment \\
\hline $\begin{array}{l}\text { Incomplete outcome data (attrition bias) } \\
\text { Exacerbations }\end{array}$ & Unclear risk & Identical placebo \\
\hline Selective reporting (reporting bias) & Unclear risk & $\begin{array}{l}\text { 'The intention-to-treat (ITT) sample was used for } \\
\text { the efficacy and safety analyses. This consisted of all } \\
\text { subjects randomised to and receiving at least one dose } \\
\text { of study medication.' }\end{array}$ \\
\hline Other bias & Low risk & $\begin{array}{l}\text { Not clear whether OCS exacerbations collected in the } \\
\text { study }\end{array}$ \\
\hline
\end{tabular}

\section{SD-004-0216}

\begin{tabular}{ll} 
Methods & Parallel-group study; multicentre trial ( 49 centres in 6 countries) \\
\hline Participants & INADEQUATELY controlled participants on inhaled glucocorticoids at baseline \\
& BASELINE INHALED STEROID DOSAGE: \\
& $400-1000 \mu$ of ICS (not specified)/day \\
& RANDOMISED: 236 \\
& LTRA: 118 \\
LABA: 118 & WITHDRAWALS:
\end{tabular}




\begin{tabular}{|c|c|}
\hline & $\begin{array}{l}\text { LTRA: } 19 / 118(16 \%) \\
\text { LABA: } 12 / 118(10 \%) \\
\text { AGE in years: mean } \pm \text { SD } \\
\text { LTRA: } 38.3 \pm \text { NS } \\
\text { LABA: } 38.1 \pm \text { NS } \\
\text { GENDER ( } \% \text { male) } \\
\text { LTRA: } 47 \% \\
\text { LABA: } 49 \% \\
\text { SEVERITY: } \\
\text { Not described } \\
\text { BASELINE FEV1 (\% predicted) } \\
\text { LTRA: } 72.03 \pm \text { SD } \\
\text { LABA: } 69.71 \pm \text { SD } \\
\text { ALLERGEN TRIGGERS } \\
\text { Not reported } \\
\text { ALLERGIC RHINITIS } \\
\text { Not reported } \\
\text { ASTHMA DURATION in years } \\
\text { LTRA: } 10.1 \pm \text { SD } \\
\text { LABA: } 12.1 \pm \text { SD } \\
\text { ELIGIBILITY CRITERIA: Male or female outpatient; age } 12-70 \text { years; treated for at least } \\
3 \text { mo with } 400-1000 \text { } \mu \text { g of inhaled glucocorticoids (presumed CFC-BDP equivalent) } \\
\text {; asthma diagnosis; FEV1 } 50-80 \% \text { predicted; } \geq 12 \% \text { reversibility in FEV1 and at least } \\
200 \text { mL after inhalation of } 1 \text { mg of terbutaline; smoking history of } \leq 10 \text { pack years } \\
\text { In the } 7 \text { days prior to randomisation one or more of the following: } \\
1 . \text { a symptom score of } \geq 1 \text { on } 4 \text { days } \\
2 . \text { awakening on } \geq 1 \text { night due to asthma symptoms } \\
3 \text {. use of } ß 2 \text {-agonists } \geq 10 \text { puffs as weekly mean } \\
\text { EXCLUSION CRITERIA: respiratory infection; clinical obstructive pulmonary disease, } \\
\text { or pulmonary dysfunction other than asthma; pregnant or lactating women; use of LABA } \\
\text { within } 1 \text { month prior to visit } 1 ; \text { previous use ever of a leukotriene antagonist; known } \\
\text { intolerance to study drugs or inhaled lactose } \\
\text { SETTING: not described }\end{array}$ \\
\hline Interventions & $\begin{array}{l}\text { LTRA + ICS versus LABA + ICS (stable dose of ICS) } \\
\text { DURATION: } \\
\text { Run-in period: } 10-14 \text { days } \\
\text { Intervention period: } 8 \text { weeks } \\
\text { INTERVENTION GROUP } 1 \\
\text { LTRA: zafirlukast } 20 \mathrm{mg} \text { bid + budesonide } 200 \mu \mathrm{g} \text { bid via turbuhaler } \\
\text { INTERVENTION GROUP } 2 \\
\text { LABA: formoterol } 12 \mu \mathrm{g} \text { bid, via turbohaler + budesonide } 200 \mu \mathrm{g} \text { bid via turbuhaler } \\
2 \text { inhalers used for combination therapy } \\
\text { CO-TREATMENT: not specified }\end{array}$ \\
\hline
\end{tabular}

Outcomes

Modified INTENTION-TO-TREAT ANALYSES for patients who received at least one dose of medication. Outcomes used at endpoint PULMONARY FUNCTION TESTS

${ }^{* *}$ Change from baseline in am PEFR; change from baseline in pm PEFR; change from baseline in FEV1 


\begin{tabular}{|c|c|c|}
\hline & $\begin{array}{l}\text { SYMPTOM SCORE } \\
\text { Change from baselin } \\
\text { TIME symptom scor } \\
\text { EXACERBATIONS } \\
\text { Exacerbations requiri } \\
\text { FUNCTIONAL STA } \\
\text { Change from baseline } \\
\text { baseline in mean DA } \\
\text { mean NIGHT-TIMP } \\
\text { INFLAMMATORY } \\
\text { Not reported } \\
\text { ADVERSE EFFECT } \\
\text { Drug related and non } \\
\text { WITHDRAWALS } \\
\text { Due to adverse effects } \\
\text { (** denotes primary o }\end{array}$ & $\begin{array}{l}\text { om scores; change from baseline NIGHT- } \\
\text { use of } ß 2 \text {-agonists (puffs/DAY); change from } \\
\text { onists (puffs/DAY); change from baseline in } \\
\text { ouffs/DAY); \% night-time awakenings }\end{array}$ \\
\hline Notes & \multicolumn{2}{|c|}{$\begin{array}{l}\text { Unpublished data } \\
\text { Received full disclosure of unpublished data provided by Roger Metcalf, AstraZeneca } \\
\text { July } 2003 \\
\text { Funded by Astra Zeneca. Report \#SD-004CR- } 0216 \\
\text { Confirmation with supportive documents received for methodology and data extraction } \\
\text { User-defined number: } 12 \text { weeks }\end{array}$} \\
\hline \multicolumn{3}{|l|}{ Risk of bias } \\
\hline Bias & Authors' judgement & Support for judgement \\
\hline $\begin{array}{l}\text { Random sequence generation (selection } \\
\text { bias) }\end{array}$ & Unclear risk & $\begin{array}{l}\text { Described as randomised; no other infor- } \\
\text { mation presented }\end{array}$ \\
\hline Allocation concealment (selection bias) & Low risk & $\begin{array}{l}\text { Opaque consecutive numbered envelopes } \\
\text { containing assignment }\end{array}$ \\
\hline $\begin{array}{l}\text { Blinding (performance bias and detection } \\
\text { bias) } \\
\text { All outcomes }\end{array}$ & Low risk & Double-dummy \\
\hline $\begin{array}{l}\text { Incomplete outcome data (attrition bias) } \\
\text { Exacerbations }\end{array}$ & Unclear risk & Analysis described as modified \\
\hline Selective reporting (reporting bias) & Unclear risk & $\begin{array}{l}\text { Not clear whether the study collected infor- } \\
\text { mation on exacerbations treated with OCS }\end{array}$ \\
\hline Other bias & Low risk & \\
\hline
\end{tabular}




\begin{tabular}{|c|c|}
\hline Methods & Parallel-group; multicentre study (16 centres in USA) \\
\hline Participants & $\begin{array}{l}\text { INADEQUATELY controlled participants on inhaled glucocorticoids and SABA prn } \\
\text { with history of EIB at baseline } \\
\text { BASELINE INHALED STEROID DOSAGE } \\
\text { Not reported } \\
\text { RANDOMISED: } 78 \\
\text { LTRA: } 39 \\
\text { LABA: } 39 \\
\text { WITHDRAWALS } \\
\text { LTRA: } 0 \text { (0\%); LABA: } 2 \text { (5\%) } \\
\text { AGE in years: mean: } \\
\text { LTRA: } 33.3 \\
\text { LABA: } 30 \\
\text { GENDER (\% male): } \\
\text { LTRA: } 29.2 \\
\text { LABA: } 41 \\
\text { SEVERITY } \\
\text { Not described } \\
\text { BASELINE } \% \text { PRED FEV1 (L) } \\
\text { LTRA: } 87.5 \\
\text { LABA: } 88.1 \\
\text { ALLERGIC RHINITIS (\%) } \\
\text { Not reported } \\
\text { ALLERGEN TRIGGERS } \\
\text { Not reported } \\
\text { ASTHMA DURATION in years: mean } \pm \text { SD: } \\
\text { LTRA: } 17.4 \pm 11.1 \\
\text { LABA: } 19.7 \pm 12 \\
\text { ELIGIBILITY CRITERIA: age } 15-45 \text { years with one year history of asthma; uncon- } \\
\text { trolled asthma on ICS for at least } 2 \text { months; treatment at randomisation with only SABA } \\
\text { and ICS; history of EIB ( } 15 \% \text { drop in FEV1 on ICS, } 20 \% \text { if not on ICS); resting FEV1 } \\
\geq 70 \% \text { predicted; } \geq 12 \% \text { increase in baseline FEV1 post-SABA; requirement for SABA } \\
\text { on } \geq 3 \text { days of last week of run-in period } \\
\text { EXCLUSION CRITERIA: respiratory infection within last } 3 \text { weeks and emergency } \\
\text { asthma care in previous } 3 \text { months; systemic corticosteroids in previous month; patients } \\
\text { were required to stop an anti-asthma medication with the exception of ICS two weeks } \\
\text { before first study visit; participants requiring oral steroids during the study were with- } \\
\text { drawn }\end{array}$ \\
\hline
\end{tabular}

Run-in Period: 1-2 weeks

Intervention Period: 4 weeks

INTERVENTION GROUP 1

LTRA: montelukast @ $10 \mathrm{mg} /$ day p.o.+ placebo salmeterol inhaler + FP $100 \mu \mathrm{g}$ bid, via Diskus

INTERVENTION GROUP 2

LABA: salmeterol $50 \mu \mathrm{g}$ bid via MDI + montelukast placebo + FP $100 \mu \mathrm{g}$ bid, via Diskus (separate inhalers) 


\begin{tabular}{ll}
\hline Outcomes & INTENTION-TO-TREAT ANALYSES - outcomes used at endpoint or 4 weeks \\
PULMONARY FUNCTION TESTS & **Challenge FEV1 \% predicted; absolute FEV1 \% predicted; fall in FEV1 post-exercise \\
& (\%); rescue bronchodilation \\
& SYMPTOM SCORES \\
& Clinic exercise assessment score \\
EXACERBATIONS & None occurred during the study (requirement for OCS) \\
FUNCTIONAL STATUS & Not reported \\
INFLAMMATORY MARKERS \\
Not reported \\
ADVERSE EFFECTS \\
Not reported \\
WITHDRAWALS \\
Reported \\
Due to adverse events: reported \\
Due to poor control: not reported \\
Overall: reported \\
(** denotes primary outcome) \\
\hline Full-text report \\
Funded by Merck \\
User-defined number: 4 weeks \\
\hline
\end{tabular}

Risk of bias

\begin{tabular}{l|l|l}
\hline Bias & Authors judgement & Support for judgement \\
\hline $\begin{array}{l}\text { Random sequence generation (selection } \\
\text { bias) }\end{array}$ & Low risk & $\begin{array}{l}\text { Computer-generated } \\
\text { schedule }\end{array}$ \\
\hline Allocation concealment (selection bias) & Unclear risk & Information not available \\
\hline $\begin{array}{l}\text { Blinding (performance bias and detection } \\
\text { bias) } \\
\text { All outcomes }\end{array}$ & Low risk & Double-dummy LTRA and LABA \\
\hline $\begin{array}{l}\text { Incomplete outcome data (attrition bias) } \\
\text { Exacerbations }\end{array}$ & Low risk & $\begin{array}{l}\text { 'A modified intention-to-treat approach } \\
\text { was used for efficacy analyses. For FEV1, } \\
\text { all randomized patients who had challenge- } \\
\text { rescue evaluations at baseline and during } \\
\text { treatment were eligible for analyses. There } \\
\text { was no imputation of missing values, and } \\
\text { prior values were not carried forward.' }\end{array}$ \\
\hline
\end{tabular}


Storms 2004 (Continued)

\begin{tabular}{|c|c|c|}
\hline Selective reporting (reporting bias) & Low risk & $\begin{array}{l}\text { No exacerbations occurred during the } \\
\text { study }\end{array}$ \\
\hline Other bias & Low risk & \\
\hline
\end{tabular}

BDP: beclomethasone; DPI: dry powder inhaler; FEV1: forced expiratory volume in one second; FP: fluticasone; GSK: GlaxoSmithKline; ICS: inhaled corticosteroids; LABA: long-acting beta-agonist; LTRA: leukotriene receptor antagonist; MDI: metered dose inhaler; PEFR: peak expiratory flow; challenge FEV1 \% predicted: FEV1 measured post-SABA after 6 minutes exercise on a treadmill exacerbating heart rate to $80-90 \%$ of individual's predicted maximum.

\section{Characteristics of excluded studies [ordered by study ID]}

\begin{tabular}{|c|c|}
\hline Study & Reason for exclusion \\
\hline Adinoff 1998 & One of the interventions was not LTRA + ICS \\
\hline Anon 1999 & Not an RCT - Montelukast vs. zafirlukast review \\
\hline Anon 2000 & Not an RCT (review) \\
\hline Anon 2001 & Not an RCT (review) \\
\hline Barnes 1997 & Not an RCT (review) \\
\hline Becker 2000 & Not an RCT (Review of montelukast) \\
\hline Bergmann 2004 & One of the tested interventions was not daily LTRA as add-on to inhaled glucocorticoid \\
\hline Bleecker 2006 & Combined analysis of two combination therapy trials versus anti-leukotriene agent alone \\
\hline Borker 2005 & No ICS co-treatment in both groups \\
\hline Brabson 2002 & No co-intervention with ICS \\
\hline Buchvald 2003 & Study duration was less than 28 days. \\
\hline Caffey 2005 & No ICS co-treatment in both groups \\
\hline Calhoun 2001 & $\begin{array}{l}\text { Non permitted drugs: study compared montelukast vs. placebo with both group receiving ICS and } \\
\text { LABA }\end{array}$ \\
\hline Cash 2001 & Not an RCT - Commentary on a previously published trial. \\
\hline Chopra 2005 & Comparison between two different LABA + ICS combinations \\
\hline
\end{tabular}


(Continued)

\begin{tabular}{|c|c|}
\hline Chuchalin 2002 & One of the interventions was not LTRA + ICS \\
\hline Currie 2002 & No systematic co-treatment with ICS \\
\hline Currie 2003a & Non permitted drug : salmeterol in both groups \\
\hline Currie 2003b & LTRA in both groups \\
\hline Currie 2003c & Duration of intervention $<30$ days \\
\hline Davis 2001 & No co-treatment with ICS and LTRA \\
\hline Dekhuijzen 2002 & Not an RCT but a review article \\
\hline Delaronde 2005 & Intervention is educational (not drug) \\
\hline Dempsey 2000 & Single dose intervention (not $>28$ days) \\
\hline Deykin 2007 & Comparison of MON/SAL with FP/SAL \\
\hline Dicpinigaitis 2002 & No systematic co-treatment with ICS \\
\hline Donohue 2001 & Review of combination therapies \\
\hline Dorinsky 2001 & No ICS used \\
\hline Dorinsky 2002 & One of the interventions was not LTRA + ICS \\
\hline Dorinsky 2002a & $\begin{array}{l}\text { One of the tested interventions was not daily LTRA as add-on to inhaled glucocorticoid (no ICS in } \\
\text { LTRA group) }\end{array}$ \\
\hline Dorinsky 2004 & $\begin{array}{l}\text { One of the tested interventions was not daily LTRA as add-on to inhaled glucocorticoid (no ICS in } \\
\text { LTRA group) }\end{array}$ \\
\hline Dunn 2001 & Review of zafirlukast \\
\hline Edelman 2000 & No co-intervention with ICS \\
\hline Edin 2002 & One of the interventions was not LTRA + ICS \\
\hline Eliraz 2001 & No co-treatment with LTRA - Compares two dry powder inhalers \\
\hline Eliraz 2002 & One of the interventions was not LTRA + ICS \\
\hline Everden 2002 & One of the interventions was not LTRA + ICS \\
\hline Gabrijelcic 2004 & One of the tested interventions was not daily LTRA as add-on to inhaled glucocorticoid \\
\hline
\end{tabular}


(Continued)

\begin{tabular}{|c|c|}
\hline Giannini 2002 & One of the interventions was not LTRA + ICS \\
\hline Grzelewska 2003 & One of the tested interventions was not daily LTRA as add-on to inhaled glucocorticoid \\
\hline Gupta 2007 & Study assessed LTRAs in addition to LABAs. \\
\hline Havlucu 2005 & Not an RCT \\
\hline Horwitz 1998 & Not an RCT (Review) \\
\hline Houghton 2004 & Comparison of propellants in formoterol - no ICS in both groups \\
\hline Inouhe 2007 & Single dose study protocol \\
\hline Jarvis 1998 & Not an RCT (Review of zafirlukast) \\
\hline Jarvis 1999 & Not an RCT but a review article on Zafirlukast. \\
\hline Jenkins 2005 & LTRA and LABA not compared as add on to ICS \\
\hline Jonsson 2004 & One of the tested interventions was not daily LTRA as add-on to inhaled glucocorticoid \\
\hline Kalberg 1999 & Retrospective data analysis, not an RCT \\
\hline Kanniess 2002 & No systematic co-treatment with ICS \\
\hline Kanniess 2002b & One of the interventions was not LABA + ICS \\
\hline Karaman 2007 & No prior treatment with ICS. \\
\hline Kardos 2001 & One of the interventions was not LABA + ICS \\
\hline Keith 2009 & Observational study \\
\hline Kemp 1998 & Not an RCT (Review) \\
\hline Knorr 2001 & No consistent co-tx with ICS in all patients (Montelukast vs placebo) \\
\hline Koenig 2008 & Study compared LABA and LTRA without background ICS in either group \\
\hline Kohrogi 1999 & Not an RCT (before and after study) \\
\hline Laviolette 1999 & One of interventions is not LABA + ICS \\
\hline Lazarus 2001 & One of interventions is not LTRA + ICS \\
\hline Lee 2004 & No LTRA and No LABA \\
\hline
\end{tabular}


(Continued)

\begin{tabular}{|c|c|}
\hline Lee 2005 & RCT testing two types of ICS \\
\hline Leflein 2002 & No systematic co-treatment with ICS \\
\hline Lipworth 2000 & Intervention $<28$ days ( 1 week only) \\
\hline Liu 1996 & $\begin{array}{l}\text { No consistent co-treatment with ICS } \\
\text { (Zileuton vs. placebo as add-on therapy to ICS) }\end{array}$ \\
\hline LOCCS & Comparison of Combination therapy with LRTA alone. \\
\hline Maspero 2008 & Study compared LABA and ICS with LTRA alone. \\
\hline McCarthy 2002 & One of the interventions was not LTRA + ICS \\
\hline Meltzer 2002 & No co-treatment with inhaled corticosteroids \\
\hline Miraglia del Giudice 2007 & No prior ICS treatment. \\
\hline Mitchell 2005 & Intervention is educational (not drug) \\
\hline Molitor 2005 & One of the interventions not LTRA \\
\hline Naedele-Risha 2001 & Not a RCT, review of LABA+ICS therapy \\
\hline Nathan 2000 & Good review of add-on therapy to ICS. Not an RCT. \\
\hline Nathan 2001b & Not a RCT, review of antileukotriene agents \\
\hline Nathan 2005 & No direct comparison between LABA and LTRA \\
\hline Nelson 2004 & Both treatment groups received FP and Salmeterol (LTRA tested as add-on to LABA) \\
\hline O'Sullivan 2003 & One of the interventions was not LABA + ICS \\
\hline Ohbayashi 2009 & Investigation of addition of anti-leukotriene to combination inhaled steroid and long-acting beta-agonist \\
\hline Ollendorf 2000 & Not an RCT, but an economic evaluation \\
\hline Oppenheimer 2008 & $\begin{array}{l}\text { Study assessed addition of anti-leukotriene (montelukast) in addition to combination LABA and ICS } \\
\text { in asthma }\end{array}$ \\
\hline Ortega-Cisneros 1998 & No leukotriene antagonists used in intervention \\
\hline Paterson 1999 & No systematic co-treatment with ICS \\
\hline Pearlman 2002 & No consistent co-tx with ICS (FP $+S$ vs Montelukast alone) \\
\hline
\end{tabular}


(Continued)

\begin{tabular}{|c|c|}
\hline Perez 2000 & Not RCT - no control group, all patients treated with montelukast \\
\hline Peroni 2002 & Short duration $<28$ days \\
\hline Peroni 2005 & Inadequate duration. \\
\hline Petermann 2004 & Review article \\
\hline Plaza 2005 & Intervention is educational (not drug) \\
\hline Price 2003 & One of the interventions was not LABA + ICS \\
\hline Riccioni 2002 & No systematic co-treatment with ICS \\
\hline Rickard 1998 & No systematic co-treatment with ICS \\
\hline Rosenhall 2003 & One of the interventions is not LTRA + ICS \\
\hline SAS40036 & LTRA administered without an ICS. \\
\hline SAS 40037 & LTRA administered without an ICS. \\
\hline SAS40066 & LTRA administered without an ICS. \\
\hline Serrier 2003 & One of the interventions is not LTRA + ICS \\
\hline Sheth 2002 & Second report - cost effectiveness analyses \\
\hline Sims 2003 & Intervention $<28$ days \\
\hline Smith 1998 & Not an RCT (Review) \\
\hline Sorkness 2007 & LTRA administered without an ICS. \\
\hline Stanford 2003 & LTRA administered without an ICS. \\
\hline Stelmach 2001 & No consistent co-intervention with ICS (RCT of ICS vs. LABA vs. LTRA) \\
\hline Stelmach 2002 & No consistent co-intervention with ICS (RCT of ICS vs. LABA vs. LTRA vs. nedocromil ) \\
\hline Stelmach $2002 a$ & No co-intervention with ICS \\
\hline Stelmach 2007 & $\begin{array}{l}\text { Participants were all on combination therapy ICS + LABA prior to enrollment and all controller med- } \\
\text { ication was withdrawn for the } 4 \text {-week run-in period. Neither before or during the run-in were the } \\
\text { participants on ICS alone prior to randomisation }\end{array}$ \\
\hline Stelmach 2008 & $\begin{array}{l}\text { Participants wereall on combination therapy ICS with either LABA or LTRA prior to enrollment and } \\
\text { were removed from all controller medications for the 4-week run-in period: consequently they were not } \\
\text { on ICS alone prior to enrollment }\end{array}$ \\
\hline
\end{tabular}


(Continued)

\begin{tabular}{|c|c|}
\hline Stempel 1998 & Not an RCT (Review) \\
\hline Stempel 2002 & Not an RCT (Review) \\
\hline Stevenson 2005 & No LTRA or LABA given. \\
\hline Terzano 2001 & One of the interventions is not LTRA + ICS \\
\hline Thien 2000 & Not an RCT (Review) \\
\hline Tolley 2002 & One of the interventions was not LTRA + ICS \\
\hline Vaquerizo 2003 & One of the interventions was not LABA + ICS \\
\hline Volovitz 1999 & No consistent co-intervention with ICS in all patients (Montelukast vs. beclomethasone ) \\
\hline Warner 2001 & Not an RCT (Review) \\
\hline Wilson 1999 & Only 14 days intervention (not $>=28$ days) \\
\hline Wilson 2001 & Only 14 days intervention (not $>=28$ days) \\
\hline Wytrychowski 2001 & Not an RCT - controlled study \\
\hline Yurdakul 2002 & $\begin{array}{l}\text { Not truly randomised as eligible patients were allocated to each treatment group according to their } \\
\text { application month to hospital (consecutive alocation not random) }\end{array}$ \\
\hline Zarkovic 1998 & One of the interventions was not LTRA + ICS \\
\hline Zimmerman 2002 & One of the interventions was not LTRA + ICS \\
\hline
\end{tabular}

\section{Characteristics of ongoing studies [ordered by study ID]}

\section{Fardon 2002}

Trial name or title

Methods

Participants

Interventions

Outcomes

Starting date 
Fardon 2002 (Continued)

Contact information

Notes

Fardon 2004

Trial name or title

Methods

Participants

Interventions

Outcomes

Starting date

Contact information

Notes

\section{Price 2001}

Trial name or title

Methods

Participants

Interventions

Outcomes

Starting date

Contact information Professor D Price (University of East Anglia, Norwich, NR4 7TJ)

Notes $\quad$ ISSN: N0254145816.

Ruggins 2003

Trial name or title

Methods

Participants

Addition to inhaled corticosteroids of long-acting beta2-agonists versus anti-leukotrienes for chronic asthma (Review) 


\section{Ruggins 2003 (Continued)}

Interventions

Outcomes

Starting date

Contact information

Notes 
DATA AND ANALYSES

Comparison 1. Long-acting $§ 2$-agonists + ICS versus leukotriene receptor antagonists + ICS

\begin{tabular}{|c|c|c|c|c|}
\hline Outcome or subgroup title & $\begin{array}{l}\text { No. of } \\
\text { studies }\end{array}$ & $\begin{array}{c}\text { No. of } \\
\text { participants }\end{array}$ & Statistical method & Effect size \\
\hline $\begin{array}{l}1 \text { Participants with one or } \\
\text { more exacerbations requiring } \\
\text { systemic corticosteroids }\end{array}$ & 6 & 5571 & Risk Ratio (M-H, Fixed, 95\% CI) & $0.83[0.71,0.97]$ \\
\hline $\begin{array}{l}1.1 \text { Montelukast } 10 \mathrm{mg} \text { once } \\
\text { daily versus Salmeterol } 50 \mathrm{mcg} \\
\text { twice daily }\end{array}$ & 5 & 5142 & Risk Ratio (M-H, Fixed, 95\% CI) & $0.83[0.71,0.97]$ \\
\hline $\begin{array}{l}1.2 \text { Zafirlukast } 20 \mathrm{mg} \text { twice } \\
\text { daily versus Salmeterol } 50 \mathrm{mcg} \\
\text { twice daily }\end{array}$ & 1 & 429 & Risk Ratio (M-H, Fixed, 95\% CI) & $0.86[0.29,2.52]$ \\
\hline $\begin{array}{l}2 \text { Morning PEF: L/min change } \\
\text { from baseline }\end{array}$ & 11 & & Mean Difference (Random, 95\% CI) & $15.36[11.35,19.37]$ \\
\hline $\begin{array}{l}2.1 \text { Montelukast } 10 \mathrm{mg} \text { once } \\
\text { daily versus Salmeterol } 50 \mathrm{mcg} \\
\text { twice daily }\end{array}$ & 8 & & Mean Difference (Random, 95\% CI) & $15.91[13.27,18.55]$ \\
\hline $\begin{array}{l}2.2 \text { Zafirlukast } 20 \mathrm{mg} \text { twice } \\
\text { daily versus salmeterol } 50 \mathrm{mcg} \\
\text { or formoterol } 9 \mathrm{mg} \text { twice daily }\end{array}$ & 2 & & Mean Difference (Random, 95\% CI) & $9.66[-1.40,20.73]$ \\
\hline $\begin{array}{l}2.3 \text { Montelukast } 10 \mathrm{mg} \text { once } \\
\text { daily versus formoterol } 18 \mathrm{mg} \\
\text { twice daily }\end{array}$ & 1 & & Mean Difference (Random, 95\% CI) & $23.8[10.89,36.71]$ \\
\hline $\begin{array}{l}3 \text { Evening PEF: L/min change } \\
\text { from baseline }\end{array}$ & 10 & & Mean Difference (Random, 95\% CI) & $12.64[10.11,15.17]$ \\
\hline $\begin{array}{l}3.1 \text { Montelukast } 10 \mathrm{mg} \text { once } \\
\text { daily versus Salmeterol } 50 \mathrm{mcg} \\
\text { twice daily }\end{array}$ & 7 & & Mean Difference (Random, 95\% CI) & $13.29[10.34,16.23]$ \\
\hline $\begin{array}{l}3.2 \text { Zafirlukast } 20 \mathrm{mg} \text { twice } \\
\text { daily versus salmeterol } 50 \mathrm{mcg} \\
\text { or formoterol } 9 \mathrm{mg} \text { twice daily }\end{array}$ & 2 & & Mean Difference (Random, 95\% CI) & $8.24[1.99,14.50]$ \\
\hline $\begin{array}{l}3.3 \text { Montelukast } 10 \mathrm{mg} \text { once } \\
\text { daily versus formoterol } 18 \mathrm{mg} \\
\text { twice daily }\end{array}$ & 1 & & Mean Difference (Random, 95\% CI) & $17.5[10.16,24.84]$ \\
\hline 4 FEV1: L change from baseline & 10 & & Mean Difference (Fixed, 95\% CI) & $0.08[0.06,0.10]$ \\
\hline $\begin{array}{l}4.1 \text { Montelukast } 10 \mathrm{mg} \text { once } \\
\text { daily vs. Salmeterol } 50 \mathrm{mcg} \\
\text { twice daily }\end{array}$ & 6 & & Mean Difference (Fixed, 95\% CI) & $0.08[0.06,0.11]$ \\
\hline $\begin{array}{l}\text { 4.2 Zafirlukast } 20 \mathrm{mg} \text { twice } \\
\text { daily vs. Salmeterol } 50 \mathrm{mcg} \text { or } \\
\text { Formoterol 9mcg twice daily }\end{array}$ & 2 & & Mean Difference (Fixed, 95\% CI) & $0.05[-0.02,0.12]$ \\
\hline $\begin{array}{l}\text { 4.3 Montelukast } 10 \mathrm{mg} \text { once } \\
\text { daily versus formoterol } 18 \mathrm{mg} \\
\text { twice daily }\end{array}$ & 2 & & Mean Difference (Fixed, 95\% CI) & $0.0[-0.09,0.09]$ \\
\hline 5 FEV1: L \% change from baseline & 1 & & Mean Difference (IV, Fixed, 95\% CI) & Totals not selected \\
\hline
\end{tabular}



daily versus formoterol $18 \mathrm{mg}$ twice daily

8 Rescue-free days: \% change from baseline

8.1 Montelukast $10 \mathrm{mg}$ once daily vs. Salmeterol $50 \mathrm{mcg}$ twice daily

8.2 Zafirlukast $20 \mathrm{mg}$ twice daily vs. Salmeterol $50 \mathrm{mcg}$ twice daily

9 Rescue medication use: puffs/day change from baseline

9.1 Montelukast $10 \mathrm{mg}$ once daily vs. Salmeterol $50 \mathrm{mcg}$ twice daily

9.2 Zafirlukast $20 \mathrm{mg}$ twice daily vs. Salmeterol $50 \mathrm{mcg}$ or Formoterol 9 mg twice daily 9.3 Montelukast $10 \mathrm{mg}$ once daily versus formoterol $18 \mathrm{mg}$ twice daily AQLQ Score (higher is better) - change from baseline 
10.1 Montelukast $10 \mathrm{mg}$ once daily vs. Salmeterol $50 \mathrm{mcg}$

twice daily

10.2 Zafirlukast $20 \mathrm{mg}$ twice daily vs. Salmeterol $50 \mathrm{mcg}$ twice daily

11 Symptom free days: \% change from baseline

11.1 Montelukast $10 \mathrm{mg}$ once daily versus Salmeterol $50 \mathrm{mcg}$ twice daily

11.2 Zafirlukast $20 \mathrm{mg}$ twice daily versus Salmeterol $50 \mathrm{mcg}$ twice daily

12 Day-time symptom scores (high is worse) - change from baseline

12.1 Montelukast $10 \mathrm{mg}$ once daily vs. Salmeterol $50 \mathrm{mcg}$ twice daily

12.2 Zafirlukast $20 \mathrm{mg}$ twice daily vs. Salmeterol $50 \mathrm{mcg}$ twice daily

13 Morning symptoms - change from baseline

13.1 Montelukast $10 \mathrm{mg}$ once daily versus formoterol $18 \mathrm{mg}$ twice daily

14 Night-time symptom score (5pt scale, higher score is worse) -

change from baseline

14.1 Zafirlukast $20 \mathrm{mg}$ twice daily vs. Salmeterol $50 \mathrm{mcg}$ twice daily

15 Change in number of night awakenings per week - change from baseline

15.1 Montelukast $10 \mathrm{mg}$ once daily vs. Salmeterol $50 \mathrm{mcg}$ twice daily

15.2 Zafirlukast $20 \mathrm{mg}$ twice daily vs. Salmeterol $50 \mathrm{mcg}$ twice daily

16 Change in \% of nights with no awakenings per week - change from baseline

16.1 Montelukast $10 \mathrm{mg}$ once daily vs. Salmeterol $50 \mathrm{mcg}$ twice daily 
16.2 Zafirlukast $20 \mathrm{mg}$ twice daily vs. Salmeterol $50 \mathrm{mcg}$ twice daily

17 Rescue-free nights (\%) - change from baseline

17.1 Montelukast $10 \mathrm{mg}$ once daily vs. Salmeterol $50 \mathrm{mcg}$ twice daily

17.2 Zafirlukast $20 \mathrm{mg}$ twice daily vs. Salmeterol $50 \mathrm{mcg}$ twice daily

18 Withdrawals for any reason 18.1 Montelukast $10 \mathrm{mg} /$ day vs Salmeterol 50ug twice daily 18.2 Zafirlukast $20 \mathrm{mg}$ twice daily vs Salmeterol $50 \mathrm{mcg}$ twice daily

18.3 Montelukast $10 \mathrm{mg} / \mathrm{d}$ versus Formoterol $18 \mathrm{mcg} / \mathrm{d}$

19 Withdrawals due to adverse events

19.1 Montelukast $10 \mathrm{mg}$ once daily versus Salmeterol $50 \mathrm{mcg}$ twice daily

19.2 Zafirlukast $20 \mathrm{mg}$ twice daily vs. Salmeterol $50 \mathrm{mcg}$ twice daily

20 Withdrawals due to poor asthma control/asthma

exacerbation

20.1 Montelukast $10 \mathrm{mg}$ once daily vs. Salmeterol $50 \mathrm{mcg}$ twice daily

20.2 Zafirlukast $20 \mathrm{mg}$ twice daily vs. Salmeterol $50 \mathrm{mcg}$ twice daily

21 Patients with one or more exacerbations requiring hospital admission

21.1 Montelukast $10 \mathrm{mg}$ once daily vs. Salmeterol $50 \mathrm{mcg}$ twice daily

22 Serious Adverse events 22.1 Montelukast $10 \mathrm{mg}$ once daily vs. Salmeterol $50 \mathrm{mcg}$ twice daily 22.2 Zafirlukast $20 \mathrm{mg}$ twice daily vs. Salmeterol $50 \mathrm{mcg}$ twice daily

23 Death
Mean Difference (IV, Fixed, 95\% CI)

Totals not selected

Mean Difference (IV, Fixed, 95\% CI)

$0.0[0.0,0.0]$

Mean Difference (IV, Fixed, 95\% CI)

$0.0[0.0,0.0]$

6291

Risk Ratio (M-H, Fixed, 95\% CI)

$0.84[0.74,0.96]$

$0.86[0.76,0.98]$

$0.65[0.40,1.06]$

$0.0[0.0,0.0]$

$1.01[0.79,1.29]$

$1.02[0.78,1.32]$

$0.92[0.41,2.05]$

$0.87[0.49,1.56]$

$1.02[0.50,2.07]$

4689 Risk Ratio (M-H, Random, 95\% CI)

$0.50[0.19,1.32]$

$1.31[0.58,2.98]$

3993 Risk Ratio (M-H, Fixed, 95\% CI)

3993 Risk Ratio (M-H, Fixed, 95\% CI)

$1.31[0.58,2.98]$

$1.35[1.00,1.82]$

$1.35[1.00,1.83]$

Risk Ratio (M-H, Fixed, 95\% CI)

$1.00[0.06,15.96]$

Risk Ratio (M-H, Fixed, 95\% CI)

Risk Ratio (M-H, Fixed, 95\% CI)
Totals not selected 

daily vs. Salmeterol $50 \mathrm{mcg}$ daily vs. Salmeterol $50 \mathrm{mcg}$ twice daily

24.3 Montelukast $10 \mathrm{mg}$ once daily versus formoterol $18 \mathrm{mg}$ twice daily

\section{Cardiovascular events}

25.1 Montelukast $10 \mathrm{mg}$ once daily vs. Salmeterol $50 \mathrm{mcg}$ twice daily

26 Oral moniliasis

26.1 Montelukast $10 \mathrm{mg}$ once daily vs. Salmeterol $50 \mathrm{mcg}$ twice daily

26.2 Montelukast $10 \mathrm{mg}$ once

Risk Ratio (M-H, Fixed, 95\% CI)

$1.09[0.77,1.53]$ daily versus formoterol $18 \mathrm{mg}$ twice daily

27 Osteopenia/osteoporosis 27.1 Montelukast $10 \mathrm{mg}$ once daily vs. Salmeterol $50 \mathrm{mcg}$ twice daily

28 Elevated liver enzymes 28.1 Montelukast $10 \mathrm{mg}$ once daily vs. Salmeterol $50 \mathrm{mcg}$ twice daily

29 Overall adverse events 29.1 Montelukast $10 \mathrm{mg}$ once daily vs. Salmeterol $50 \mathrm{mcg}$ twice daily

29.2 Zafirlukast $20 \mathrm{mg}$ twice

Risk Ratio (M-H, Fixed, 95\% CI) Risk Ratio (M-H, Fixed, 95\% CI)

Totals not selected $0.0[0.0,0.0]$ daily vs. Salmeterol $50 \mathrm{mcg}$ twice daily

30 Patient treatment satisfaction 30.1 Montelukast $10 \mathrm{mg}$ once daily vs. Salmeterol $50 \mathrm{mcg}$ twice daily 30.2 Zafirlukast $20 \mathrm{mg}$ twice daily vs. Salmeterol $50 \mathrm{mcg}$ twice daily

31 Change from baseline in serum eosinophils (x 10e9/L) 


\begin{tabular}{|c|c|c|c|c|}
\hline Outcome or subgroup title & $\begin{array}{l}\text { No. of } \\
\text { studies }\end{array}$ & $\begin{array}{c}\text { No. of } \\
\text { participants }\end{array}$ & Statistical method & Effect size \\
\hline $\begin{array}{l}1 \text { Participants with one or } \\
\text { more exacerbations requiring } \\
\text { systemic corticosteroids: } \\
\text { number of inhaler devices }\end{array}$ & 6 & & Risk Ratio (IV, Fixed, 95\% CI) & Subtotals only \\
\hline $\begin{array}{l}\text { 1.1 Single device for LABA + } \\
\text { ICS }\end{array}$ & 2 & 1252 & Risk Ratio (IV, Fixed, 95\% CI) & $0.49[0.29,0.83]$ \\
\hline $\begin{array}{l}1.2 \text { Two devices for LABA + } \\
\text { ICS }\end{array}$ & 4 & 4319 & Risk Ratio (IV, Fixed, 95\% CI) & $0.88[0.75,1.04]$ \\
\hline $\begin{array}{l}2 \text { Participants with one or } \\
\text { more exacerbations requiring } \\
\text { systemic corticosteroids: dose } \\
\text { of ICS }\end{array}$ & 6 & & Risk Ratio (M-H, Fixed, 95\% CI) & Subtotals only \\
\hline 2.1 Low dose of ICS & 3 & 2742 & Risk Ratio (M-H, Fixed, 95\% CI) & $0.80[0.64,1.00]$ \\
\hline 2.2 Medium dose of ICS & 1 & 1452 & Risk Ratio (M-H, Fixed, 95\% CI) & $0.85[0.67,1.08]$ \\
\hline 2.3 Mixed & 1 & 948 & Risk Ratio (M-H, Fixed, 95\% CI) & $0.99[0.50,1.96]$ \\
\hline 2.4 Unclear & 1 & 429 & Risk Ratio (M-H, Fixed, 95\% CI) & $0.86[0.29,2.52]$ \\
\hline $\begin{array}{l}3 \text { Participants with one or } \\
\text { more exacerbations requiring } \\
\text { systemic corticosteroids: study } \\
\text { duration }\end{array}$ & 6 & & Risk Ratio (M-H, Fixed, 95\% CI) & Subtotals only \\
\hline 3.112 weeks or less & 4 & 2629 & Risk Ratio (M-H, Fixed, 95\% CI) & $0.65[0.45,0.96]$ \\
\hline 3.248 weeks & 2 & 2942 & Risk Ratio (M-H, Fixed, 95\% CI) & $0.88[0.74,1.04]$ \\
\hline $\begin{array}{l}4 \text { Serious adverse effects stratified } \\
\text { by number of inhaler devices } \\
\text { used for LABA + ICS }\end{array}$ & 7 & & Risk Ratio (IV, Fixed, 95\% CI) & Subtotals only \\
\hline $\begin{array}{l}\text { 4.1 Single device for LABA + } \\
\text { ICS }\end{array}$ & 3 & 1318 & Risk Ratio (IV, Fixed, 95\% CI) & $0.72[0.26,1.99]$ \\
\hline $\begin{array}{l}4.2 \text { Two devices for LABA + } \\
\text { ICS }\end{array}$ & 4 & 4340 & Risk Ratio (IV, Fixed, 95\% CI) & $1.43[1.04,1.97]$ \\
\hline
\end{tabular}

\section{Comparison 3. MD archive from previous review version}

\begin{tabular}{|c|c|c|c|c|}
\hline Outcome or subgroup title & $\begin{array}{l}\text { No. of } \\
\text { studies }\end{array}$ & $\begin{array}{c}\text { No. of } \\
\text { participants }\end{array}$ & Statistical method & Effect size \\
\hline $\begin{array}{l}1 \text { Morning PEF }(\mathrm{L} / \mathrm{min}) \text { - change } \\
\text { from baseline }\end{array}$ & 10 & & Mean Difference (IV, Fixed, 95\% CI) & Totals not selected \\
\hline $\begin{array}{l}2 \text { Evening PEF (L/min) - change } \\
\text { from baseline }\end{array}$ & 9 & & Mean Difference (IV, Fixed, 95\% CI) & Totals not selected \\
\hline 3 FEV1 (L) - change from baseline & 8 & & Mean Difference (IV, Fixed, 95\% CI) & Totals not selected \\
\hline $\begin{array}{l}4 \text { Symptom free days (\%) - change } \\
\text { from baseline }\end{array}$ & 5 & & Mean Difference (IV, Random, 95\% CI) & Totals not selected \\
\hline
\end{tabular}


Analysis I.I. Comparison I Long-acting B2-agonists + ICS versus leukotriene receptor antagonists + ICS, Outcome I Participants with one or more exacerbations requiring systemic corticosteroids.

Review: Addition to inhaled corticosteroids of long-acting beta2-agonists versus anti-leukotrienes for chronic asthma

Comparison: I Long-acting 2-agonists + ICS versus leukotriene receptor antagonists + ICS

Outcome: I Participants with one or more exacerbations requiring systemic corticosteroids

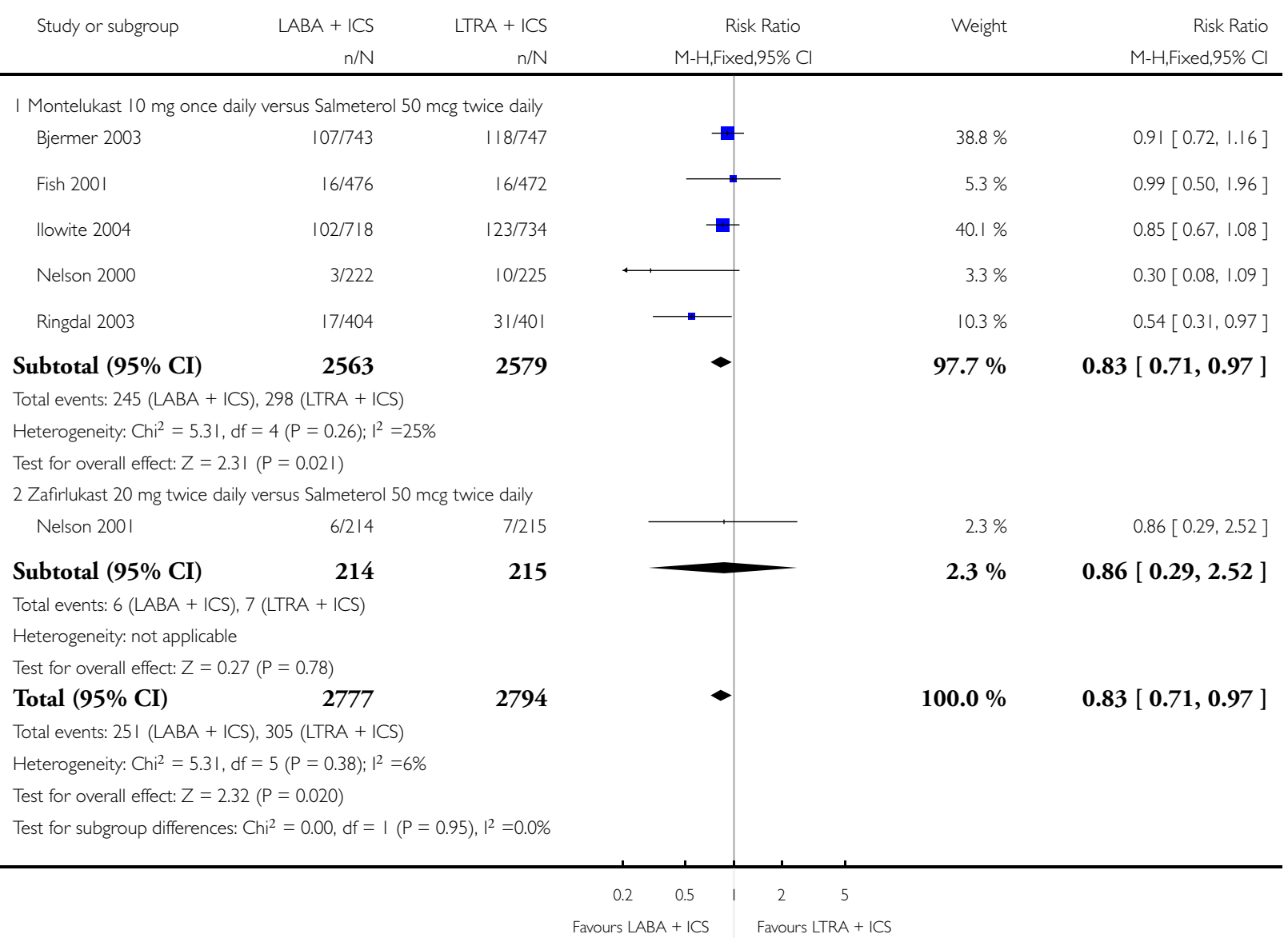


Analysis I.2. Comparison I Long-acting B2-agonists + ICS versus leukotriene receptor antagonists + ICS, Outcome 2 Morning PEF: L/min change from baseline.

Review: Addition to inhaled corticosteroids of long-acting beta2-agonists versus anti-leukotrienes for chronic asthma

Comparison: I Long-acting 2-agonists + ICS versus leukotriene receptor antagonists + ICS

Outcome: 2 Morning PEF: L/min change from baseline

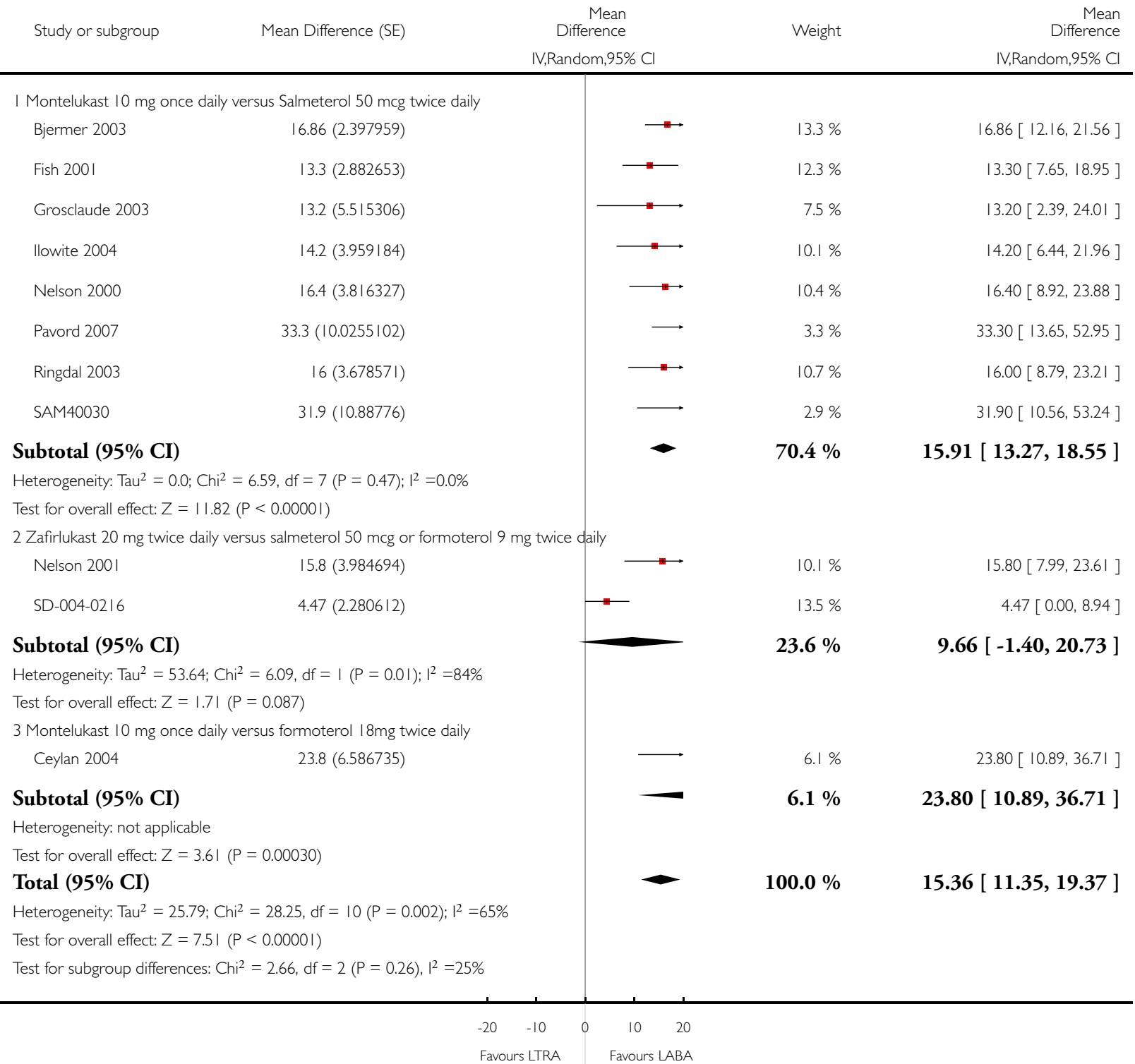


Analysis I.3. Comparison I Long-acting B2-agonists + ICS versus leukotriene receptor antagonists + ICS, Outcome 3 Evening PEF: L/min change from baseline.

Review: Addition to inhaled corticosteroids of long-acting beta2-agonists versus anti-leukotrienes for chronic asthma

Comparison: I Long-acting 2-agonists + ICS versus leukotriene receptor antagonists + ICS

Outcome: 3 Evening PEF: L/min change from baseline

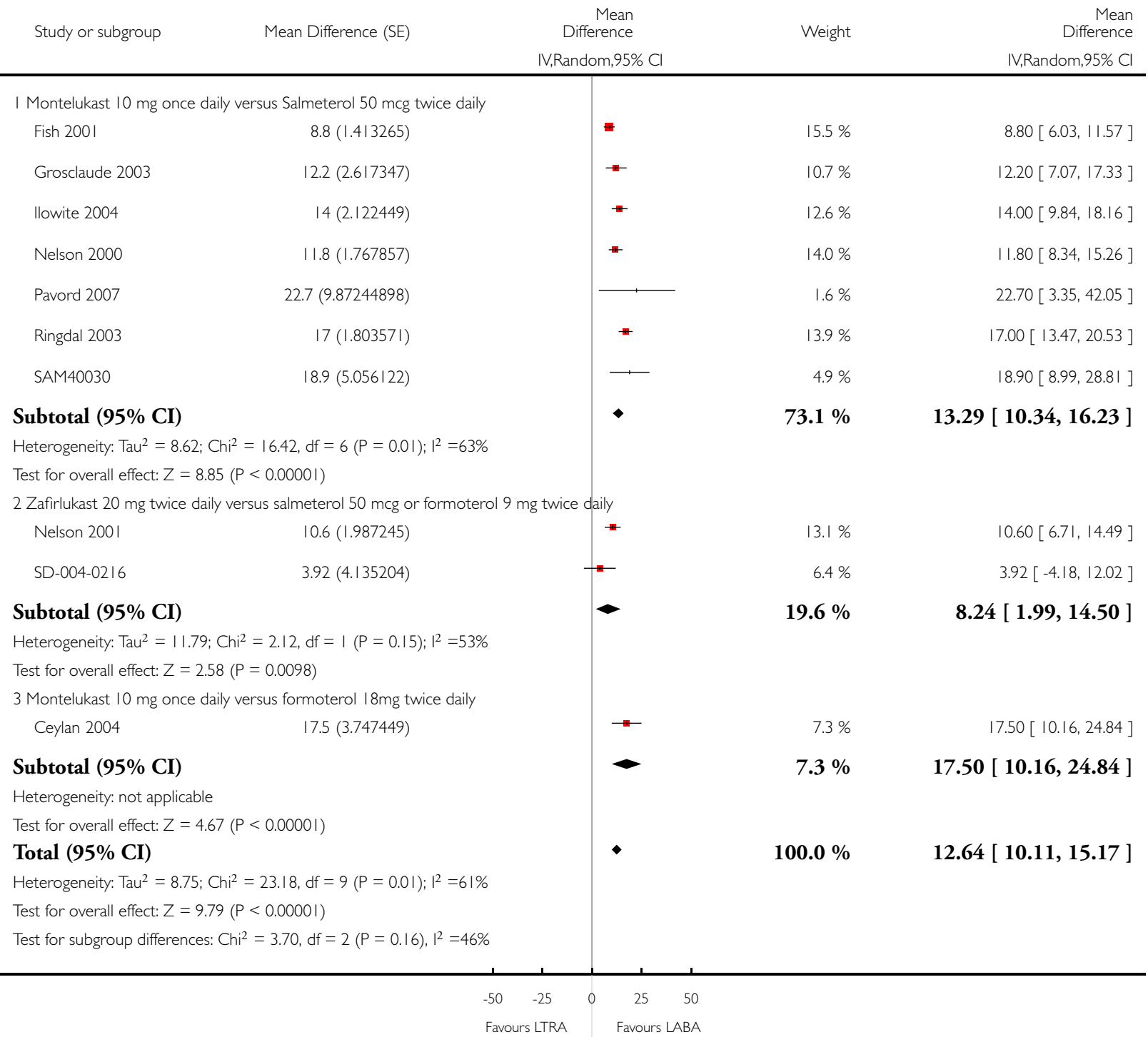


Analysis I.4. Comparison I Long-acting B2-agonists + ICS versus leukotriene receptor antagonists + ICS, Outcome 4 FEVI: $L$ change from baseline.

Review: Addition to inhaled corticosteroids of long-acting beta2-agonists versus anti-leukotrienes for chronic asthma

Comparison: I Long-acting 2-agonists + ICS versus leukotriene receptor antagonists + ICS

Outcome: $4 \mathrm{FEVI}$ : L change from baseline

Study or subgroup Mean Difference (SE)

I Montelukast $10 \mathrm{mg}$ once daily vs. Salmeterol $50 \mathrm{mcg}$ twice daily

Bjermer 2003

$0.08(0.03061225)$

llowite 2004

$0.07(0.01530612)$

Nelson 2000

$0.15(0.04081633)$

Pavord 2007

$0.11(0.107 \mid 4286)$

Ringdal 2003

$0.11(0.03061225)$

SAM 40030

$0.08(0.09693878)$

Subtotal (95\% CI)

Heterogeneity: $\mathrm{Chi}^{2}=4.25, \mathrm{df}=5(\mathrm{P}=0.5 \mathrm{I}) ; \mathrm{I}^{2}=0.0 \%$

Test for overall effect: $Z=7.19(P<0.00001)$

2 Zafirlukast $20 \mathrm{mg}$ twice daily vs. Salmeterol $50 \mathrm{mcg}$ or Formoterol $9 \mathrm{mcg}$ twice daily

Nelson $2001 \quad 0.03(0.04081633)$

SD-004-0216

$0.11(0.07 \mid 42857)$

Subtotal $(95 \% \mathrm{CI})$

Heterogeneity: Chi $^{2}=0.95, \mathrm{df}=\mathrm{I}(\mathrm{P}=0.33) ; \mathrm{I}^{2}=0.0 \%$

Test for overall effect: $Z=1.40(P=0.16)$

3 Montelukast $10 \mathrm{mg}$ once daily versus formoterol $18 \mathrm{mg}$ twice daily

Ceylan 2004

Green 2006

$0(0.047449)$

Subtotal $(95 \%$ CI)

Heterogeneity: $\mathrm{Chi}^{2}=0.0, \mathrm{df}=0(\mathrm{P}=1.00) ;\left.\right|^{2}=0.0 \%$

Test for overall effect: $Z=0.0(P=1.0)$

Total (95\% CI)

Heterogeneity: $\mathrm{Chi}^{2}=8.85, \mathrm{df}=8(\mathrm{P}=0.36) ; \mathrm{I}^{2}=10 \%$

Test for overall effect: $Z=7.07(P<0.0000 \mathrm{I})$

Test for subgroup differences: $\mathrm{Chi}^{2}=3.66, \mathrm{df}=2(\mathrm{P}=0.16), \mathrm{I}^{2}=45 \%$

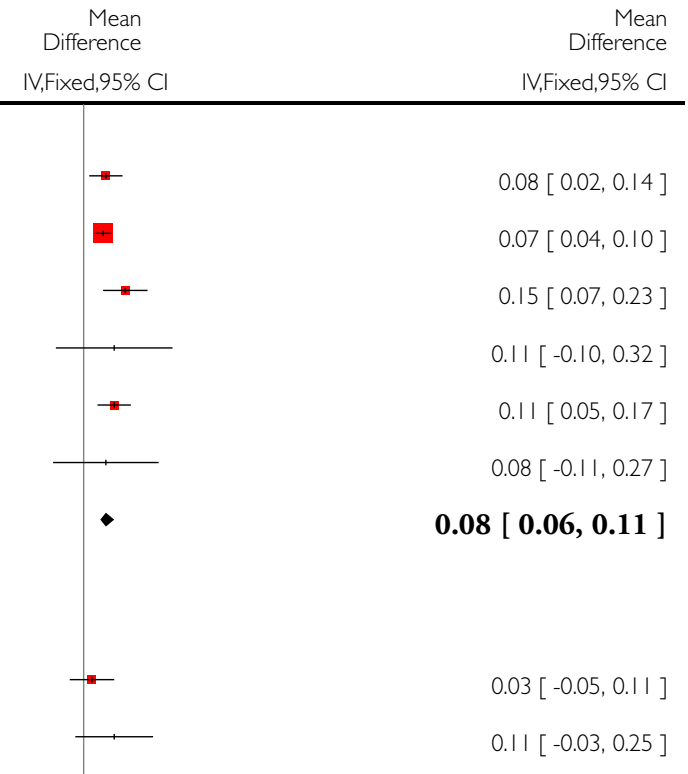

$0.05[-0.02,0.12]$

$0.0[0.0,0.0]$

$0.0[-0.09,0.09]$

$0.0[-0.09,0.09]$

$0.08[0.06,0.10]$

Addition to inhaled corticosteroids of long-acting beta2-agonists versus anti-leukotrienes for chronic asthma (Review) 
Analysis I.5. Comparison I Long-acting B2-agonists + ICS versus leukotriene receptor antagonists + ICS, Outcome 5 FEVI: $L$ \% change from baseline.

Review: Addition to inhaled corticosteroids of long-acting beta2-agonists versus anti-leukotrienes for chronic asthma

Comparison: I Long-acting 2-agonists + ICS versus leukotriene receptor antagonists + ICS

Outcome: $5 \mathrm{FEVI}$ : L \% change from baseline

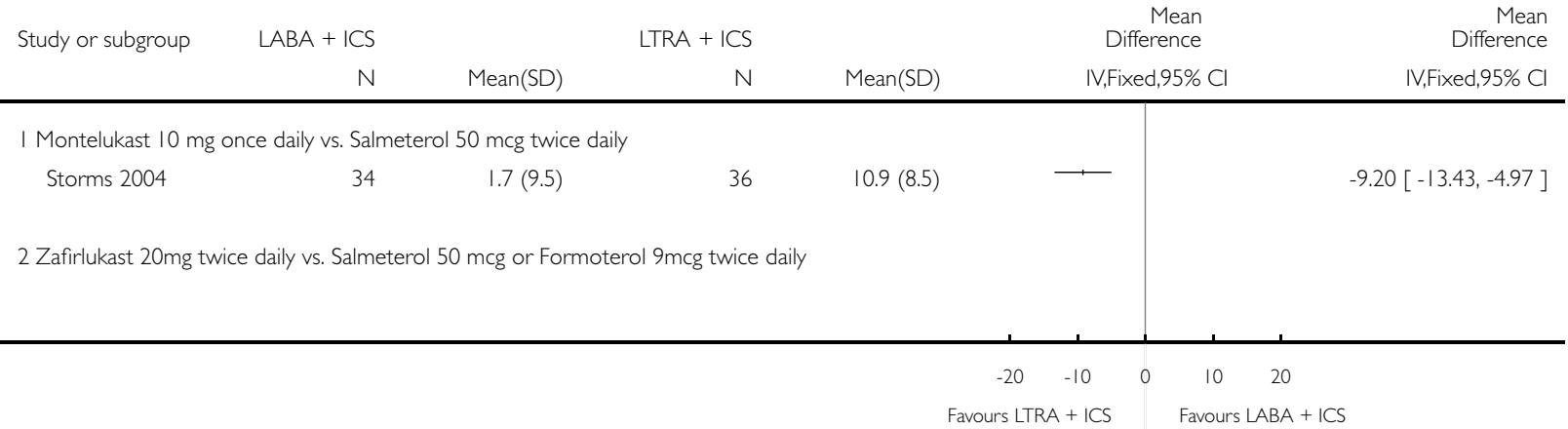

Analysis I.6. Comparison I Long-acting B2-agonists + ICS versus leukotriene receptor antagonists + ICS, Outcome 6 FEVI: \% predicted end of treatment.

Review: Addition to inhaled corticosteroids of long-acting beta2-agonists versus anti-leukotrienes for chronic asthma

Comparison: I Long-acting 2-agonists + ICS versus leukotriene receptor antagonists + ICS

Outcome: $6 \mathrm{FEVI}: \%$ predicted end of treatment

$\begin{array}{lrrr} & & \text { Mean } \\ \text { Study or subgroup } & \text { LABA + ICS } & \text { LTRA + ICS } & \text { Mean } \\ \text { Difference }\end{array}$

I Montelukast $10 \mathrm{mg}$ once daily vs. Salmeterol $50 \mathrm{mcg}$ twice daily

$\begin{array}{lllll}\text { Storms } 2004 & 34 & 91.2(10.1) & 36 & 86.6(11)\end{array}$

IV,Random,95\% Cl IV,Random,95\% Cl

2 Zafirlukast $20 \mathrm{mg}$ twice daily vs. Salmeterol $50 \mathrm{mcg}$ or Formoterol $9 \mathrm{mcg}$ twice daily

3 Montelukast $5 \mathrm{mg}$ once daily versus formoterol $18 \mathrm{mg}$ twice daily

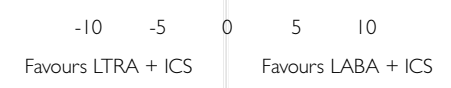




\section{Analysis I.7. Comparison I Long-acting B2-agonists + ICS versus leukotriene receptor antagonists + ICS, Outcome $7 \%$ fall in FEVI POST-EXERCISE.}

Review: Addition to inhaled corticosteroids of long-acting beta2-agonists versus anti-leukotrienes for chronic asthma

Comparison: I Long-acting 2-agonists + ICS versus leukotriene receptor antagonists + ICS

Outcome: $7 \%$ fall in FEVI POST-EXERCISE

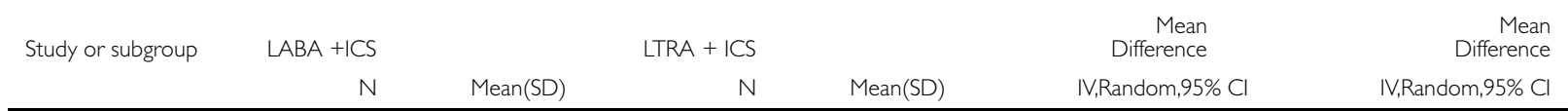

I Montelukast $10 \mathrm{mg}$ once daily versus salmeterol $50 \mathrm{mcg}$ twice daily

$\begin{array}{lllll}\text { Storms } 2004 & 34 & 10.5(10) & 36 & 7.7(8.1)\end{array}$

2 Zafirlukast $20 \mathrm{mg}$ twice daily versus salmeterol $50 \mathrm{mcg}$ or formoterol $9 \mathrm{mcg}$ twice daily

3 Montelukast $5 \mathrm{mg}$ once daily versus formoterol $18 \mathrm{mg}$ twice daily

$7(8.1)$

V,Random, $95 \% \mathrm{Cl}$

$2.80[-1.48,7.08]$

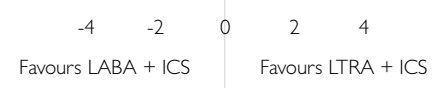

Analysis I.8. Comparison I Long-acting B2-agonists + ICS versus leukotriene receptor antagonists + ICS, Outcome 8 Rescue-free days: \% change from baseline.

Review: Addition to inhaled corticosteroids of long-acting beta2-agonists versus anti-leukotrienes for chronic asthma

Comparison: I Long-acting 2-agonists + ICS versus leukotriene receptor antagonists + ICS

Outcome: 8 Rescue-free days: \% change from baseline

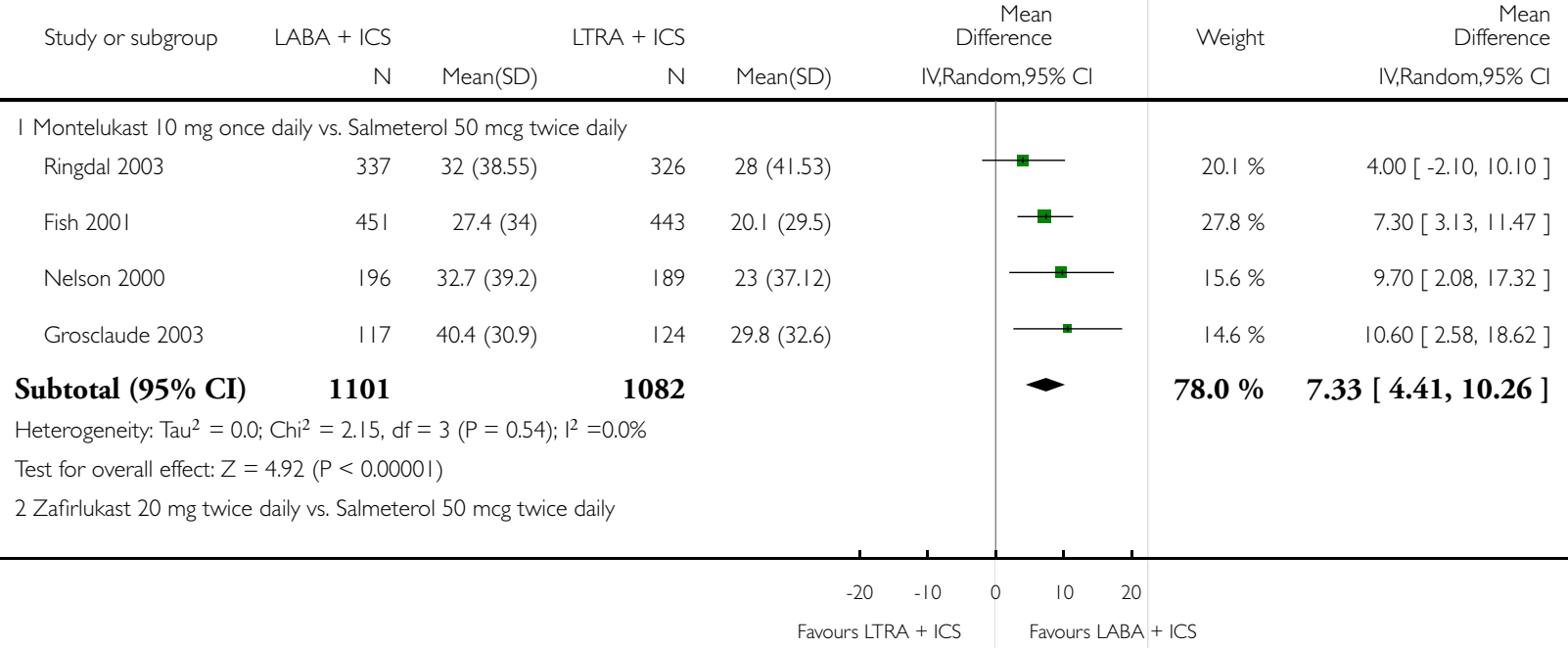

(Continued ...)

Addition to inhaled corticosteroids of long-acting beta2-agonists versus anti-leukotrienes for chronic asthma (Review) 


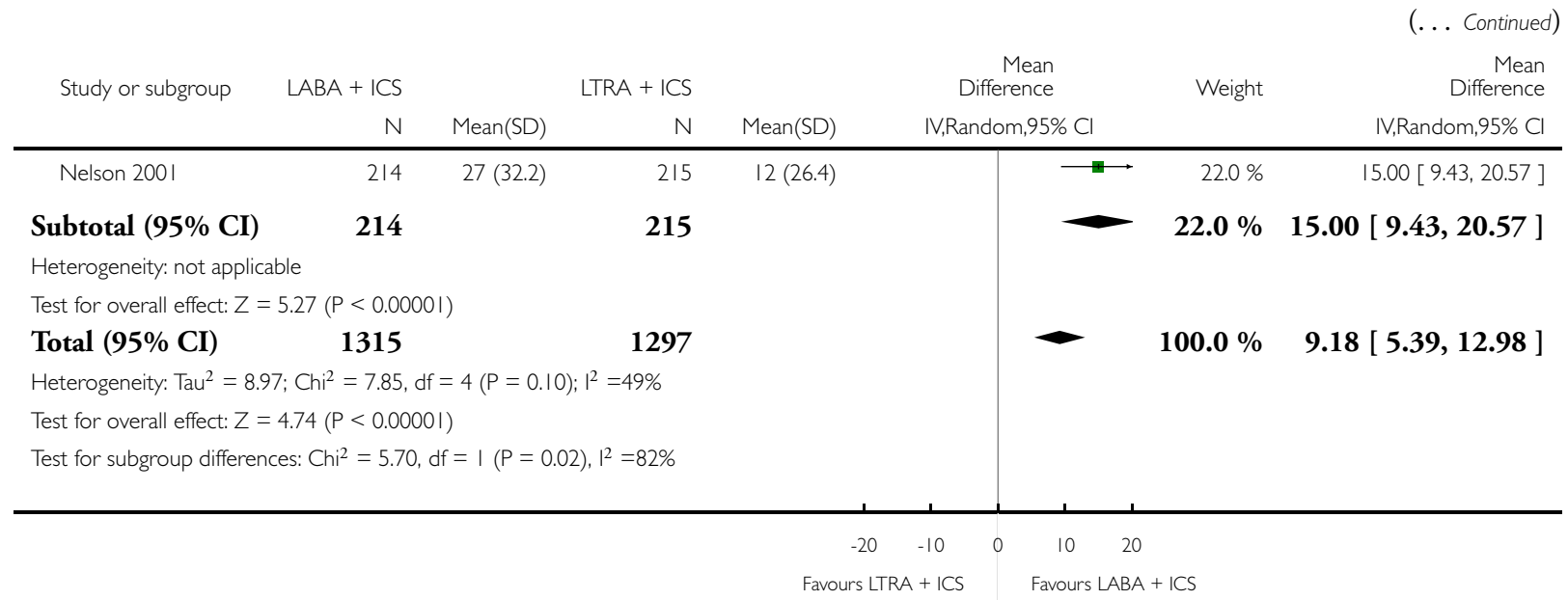

\section{Analysis I.9. Comparison I Long-acting B2-agonists + ICS versus leukotriene receptor antagonists + ICS, Outcome 9 Rescue medication use: puffs/day change from baseline.}

Review: Addition to inhaled corticosteroids of long-acting beta2-agonists versus anti-leukotrienes for chronic asthma

Comparison: I Long-acting 2-agonists + ICS versus leukotriene receptor antagonists + ICS

Outcome: 9 Rescue medication use: puffs/day change from baseline

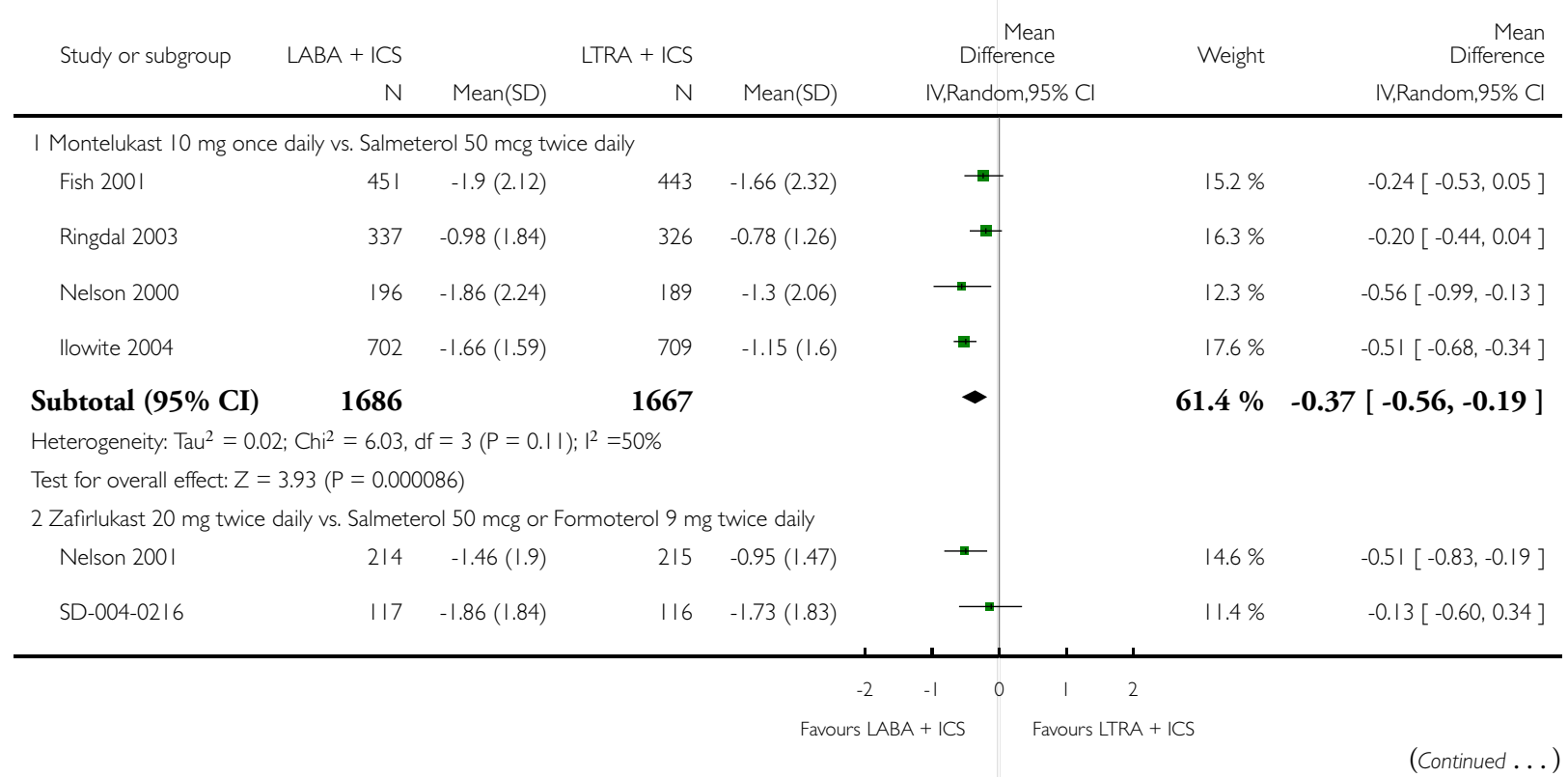


(... Continued)

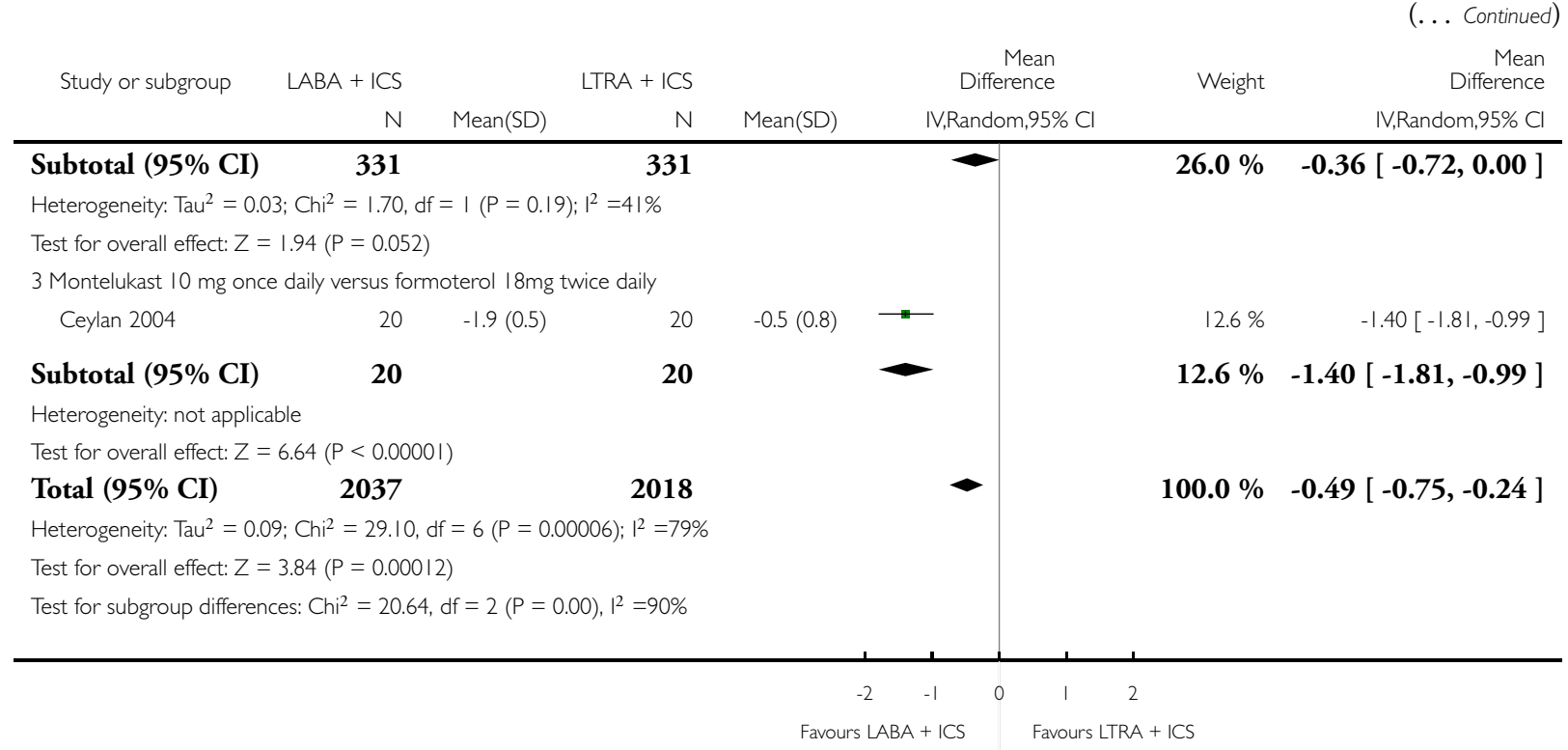


Analysis I.10. Comparison I Long-acting B2-agonists + ICS versus leukotriene receptor antagonists + ICS, Outcome 10 Change in Global asthma QoL AQLQ Score (higher is better) - change from baseline.

Review: Addition to inhaled corticosteroids of long-acting beta2-agonists versus anti-leukotrienes for chronic asthma

Comparison: I Long-acting 2-agonists + ICS versus leukotriene receptor antagonists + ICS

Outcome: 10 Change in Global asthma QoL AQLQ Score (higher is better) - change from baseline

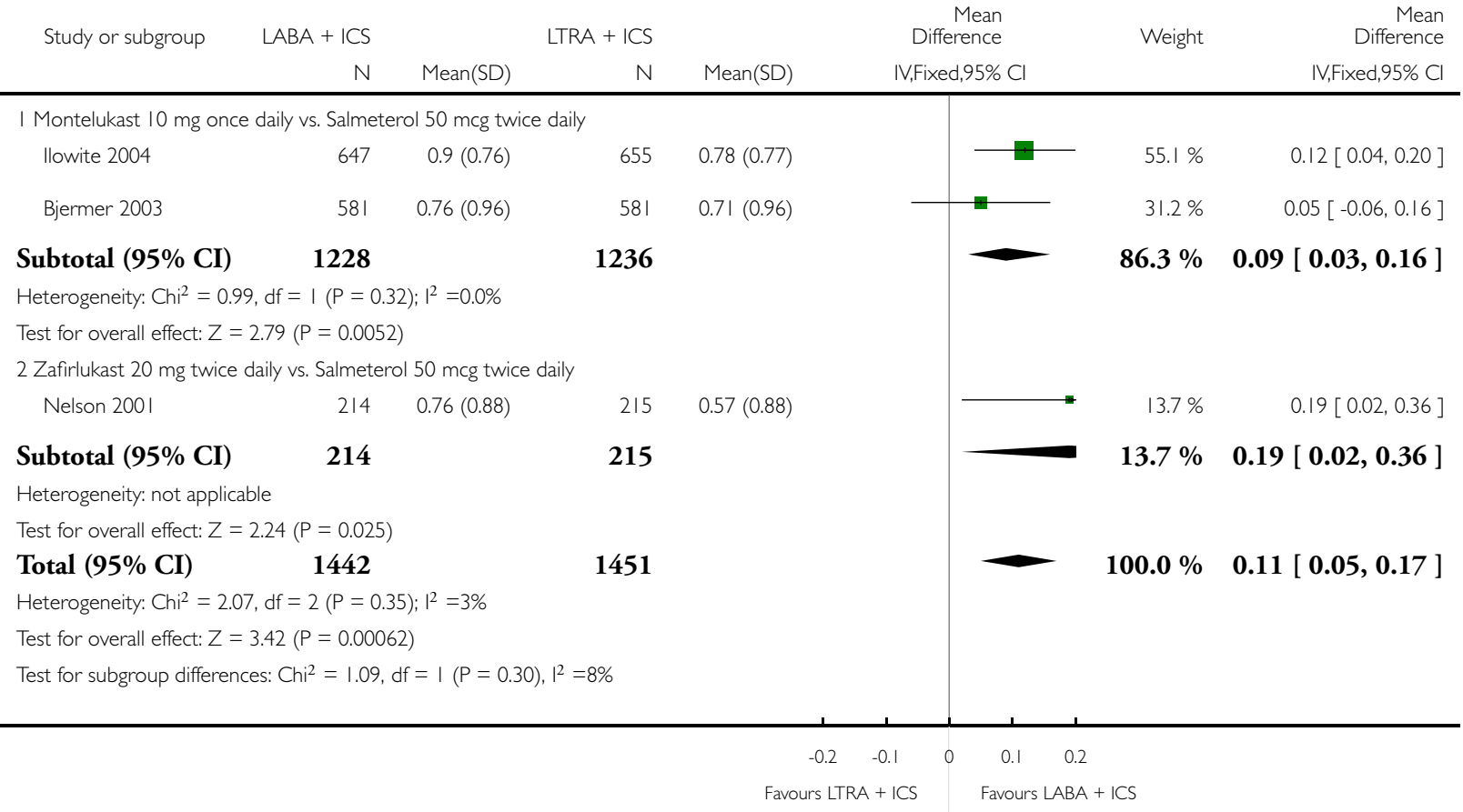


Analysis I.I I. Comparison I Long-acting B2-agonists + ICS versus leukotriene receptor antagonists + ICS, Outcome II Symptom free days: \% change from baseline.

Review: Addition to inhaled corticosteroids of long-acting beta2-agonists versus anti-leukotrienes for chronic asthma

Comparison: I Long-acting 2-agonists + ICS versus leukotriene receptor antagonists + ICS

Outcome: II Symptom free days: \% change from baseline

$\begin{array}{lcr}\text { Study or subgroup } & \text { Mean } & \text { Mean } \\ \text { Mean Difference } & \text { Weight } & \text { Difference } \\ \text { IV,Fixed,95\% Cl } & \text { IV,Fixed,95\% Cl }\end{array}$

I Montelukast $10 \mathrm{mg}$ once daily versus Salmeterol 50 mcg twice daily

$\begin{array}{lr}\text { Fish 200I } & 7.98(2.44898) \\ \text { Grosclaude 2003 } & 9.3(4.209 \text { | } 84) \\ \text { Nelson } 2000 & 1.1(3.607 \mid 43) \\ \text { Pavord 2007 } & 13.2(7.5) \\ \text { Ringdal } 2003 & 3(3.0408 \mid 6)\end{array}$
IV,Fixed,95\% Cl

Subtotal $(95 \%$ CI $)$

Heterogeneity: $\mathrm{Chi}^{2}=5.00, \mathrm{df}=4(\mathrm{P}=0.29) ; \mathrm{I}^{2}=20 \%$

Test for overall effect: $Z=3.83(P=0.00013)$

2 Zafirlukast $20 \mathrm{mg}$ twice daily versus Salmeterol $50 \mathrm{mcg}$ twice daily

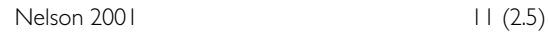

Heterogeneity: not applicable

Test for overall effect: $Z=4.40(P=0.0000 \mathrm{I} I)$

Total (95\% CI)

$-\quad 100.0 \%$

Heterogeneity: $\mathrm{Chi}^{2}=8.07, \mathrm{df}=5(\mathrm{P}=0.15) ; \mathrm{I}^{2}=38 \%$

$7.27[4.71,9.83]$

Test for overall effect: $Z=5.56(P<0.0000 \mathrm{I})$

Test for subgroup differences: $\mathrm{Chi}^{2}=3.06, \mathrm{df}=\mathrm{I}(\mathrm{P}=0.08), \mathrm{I}^{2}=67 \%$

$\begin{array}{ccccc}-20 & -10 & 0 & 10 & 20 \\ \text { ours LTRA + ICS } & & \text { Favours LABA + ICS }\end{array}$


Analysis I.I2. Comparison I Long-acting B2-agonists + ICS versus leukotriene receptor antagonists + ICS, Outcome 12 Day-time symptom scores (high is worse) - change from baseline.

Review: Addition to inhaled corticosteroids of long-acting beta2-agonists versus anti-leukotrienes for chronic asthma

Comparison: I Long-acting 2-agonists + ICS versus leukotriene receptor antagonists + ICS

Outcome: 12 Day-time symptom scores (high is worse) - change from baseline

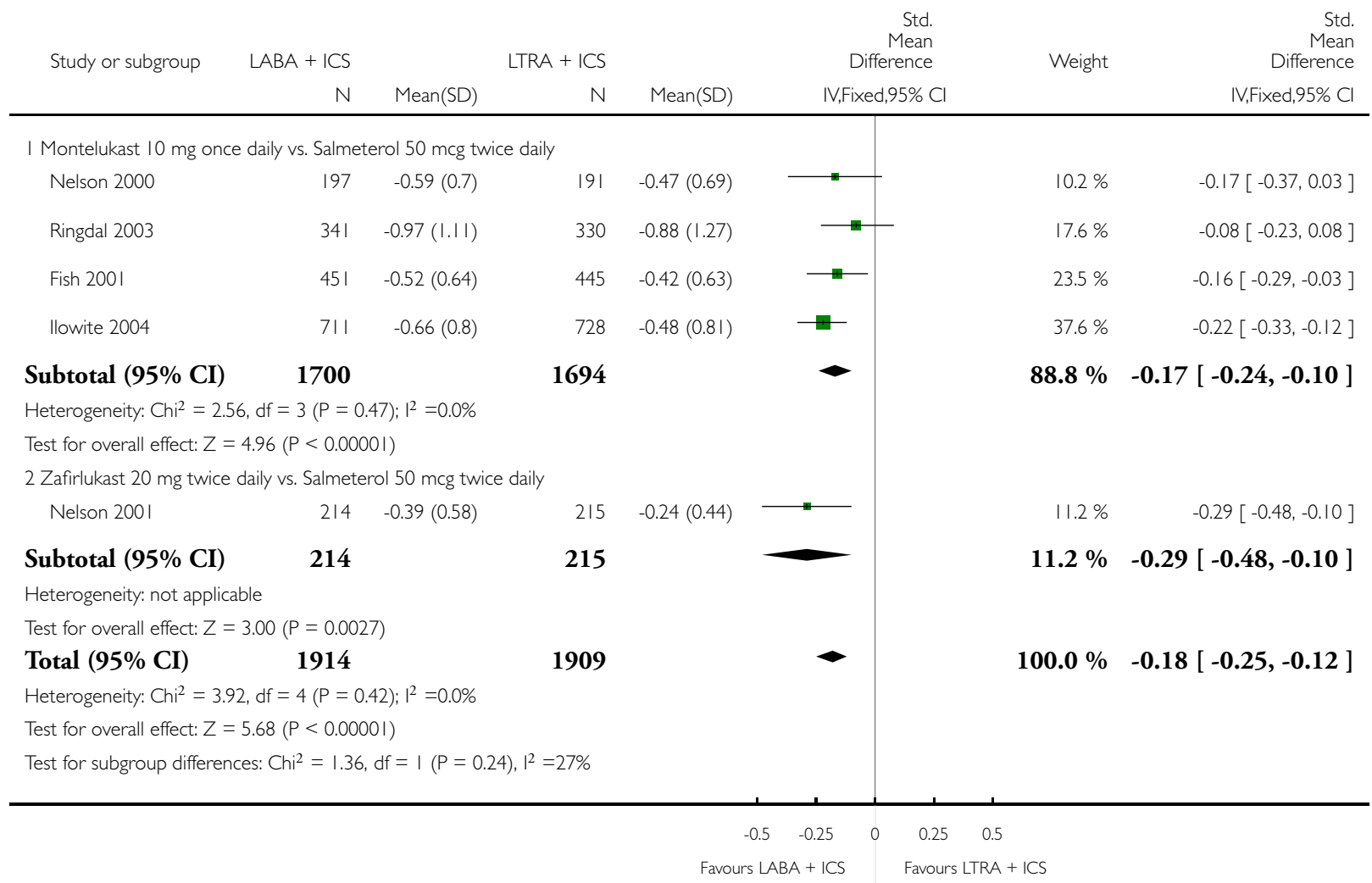


Analysis I.I3. Comparison I Long-acting B2-agonists + ICS versus leukotriene receptor antagonists + ICS, Outcome 13 Morning symptoms - change from baseline.

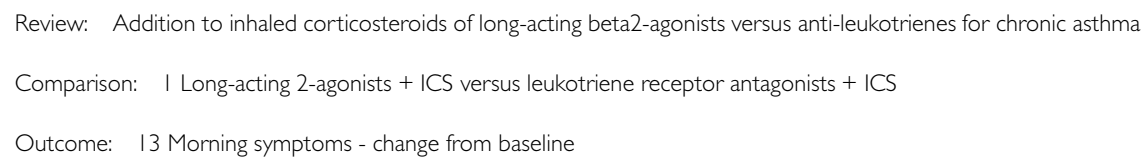

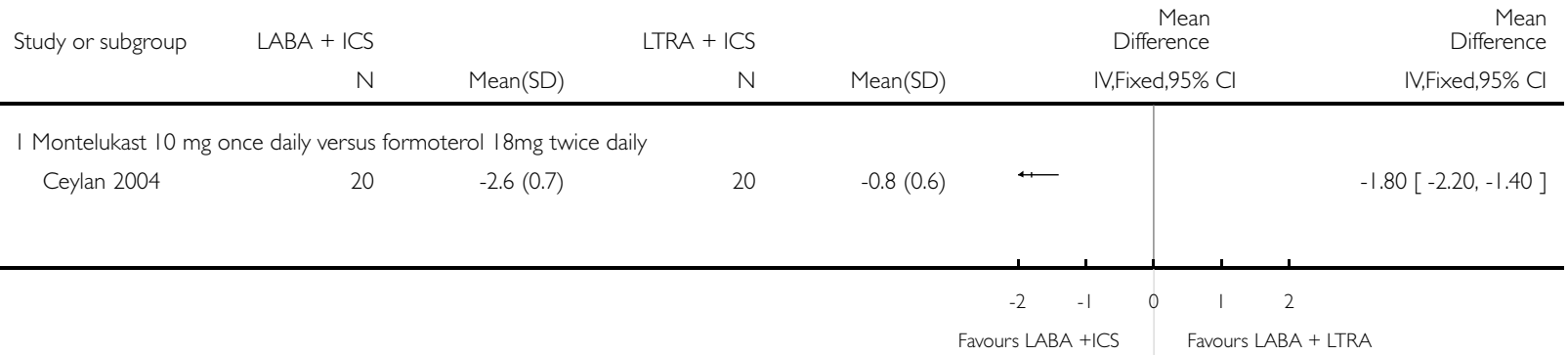

Analysis I.I4. Comparison I Long-acting B2-agonists + ICS versus leukotriene receptor antagonists + ICS, Outcome 14 Night-time symptom score (5pt scale, higher score is worse) - change from baseline.

Review: Addition to inhaled corticosteroids of long-acting beta2-agonists versus anti-leukotrienes for chronic asthma

Comparison: I Long-acting 2-agonists + ICS versus leukotriene receptor antagonists + ICS

Outcome: 14 Night-time symptom score (5pt scale, higher score is worse) - change from baseline

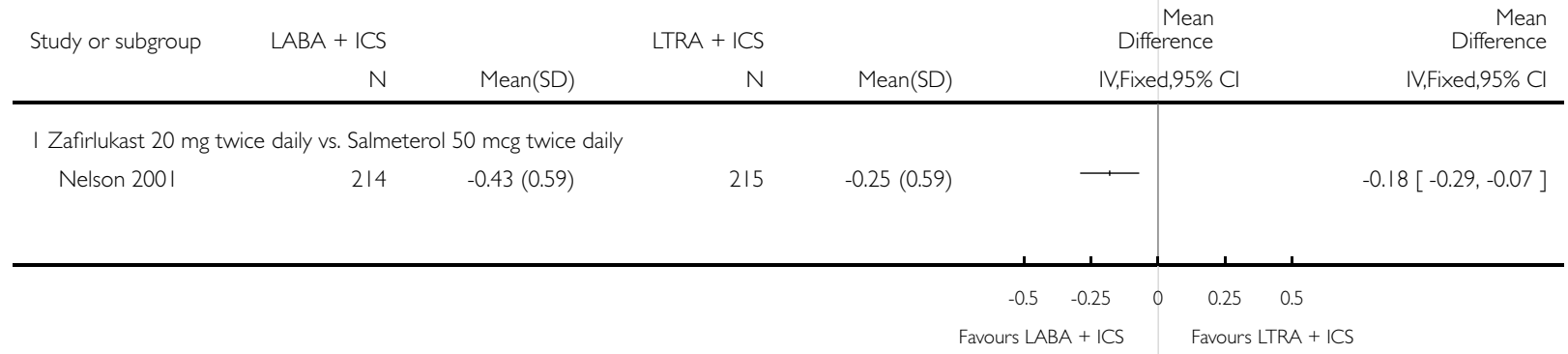


Analysis I.I5. Comparison I Long-acting B2-agonists + ICS versus leukotriene receptor antagonists + ICS, Outcome 15 Change in number of night awakenings per week - change from baseline.

Review: Addition to inhaled corticosteroids of long-acting beta2-agonists versus anti-leukotrienes for chronic asthma

Comparison: I Long-acting 2-agonists + ICS versus leukotriene receptor antagonists + ICS

Outcome: 15 Change in number of night awakenings per week - change from baseline

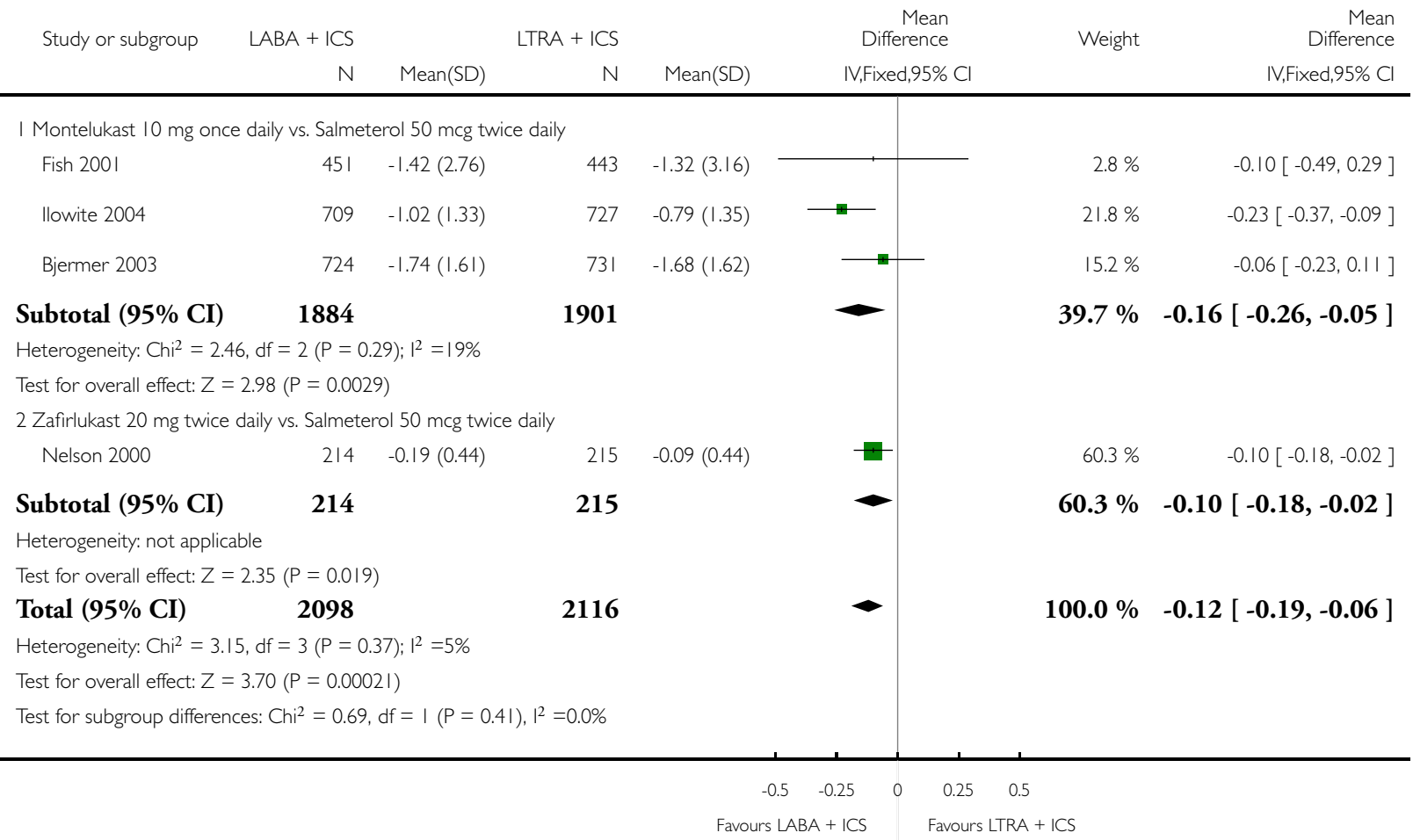


Analysis I.16. Comparison I Long-acting B2-agonists + ICS versus leukotriene receptor antagonists + ICS, Outcome 16 Change in \% of nights with no awakenings per week - change from baseline.

Review: Addition to inhaled corticosteroids of long-acting beta2-agonists versus anti-leukotrienes for chronic asthma

Comparison: I Long-acting 2-agonists + ICS versus leukotriene receptor antagonists + ICS

Outcome: 16 Change in \% of nights with no awakenings per week - change from baseline

\begin{tabular}{|c|c|c|c|c|c|c|c|}
\hline \multirow[t]{2}{*}{ Study or subgroup } & \multirow{2}{*}{$\begin{array}{r}L A B A+I C S \\
N\end{array}$} & \multicolumn{3}{|c|}{ LTRA + ICS } & \multirow{2}{*}{$\begin{array}{c}\text { Mean } \\
\text { Difference } \\
\text { IV,Fixed,95\% Cl }\end{array}$} & \multirow[t]{2}{*}{ Weight } & \multirow{2}{*}{$\begin{array}{r}\text { Mean } \\
\text { Difference } \\
\text { IV,Fixed,95\% Cl }\end{array}$} \\
\hline & & Mean(SD) & $\mathrm{N}$ & Mean(SD) & & & \\
\hline \multicolumn{8}{|c|}{ I Montelukast 10 mg once daily vs. Salmeterol 50 mcg twice daily } \\
\hline Grosclaude 2003 & 118 & $26.4(31)$ & 126 & $19.8(30)$ & 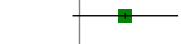 & $27.5 \%$ & $6.60[-1.06,14.26]$ \\
\hline Subtotal (95\% CI) & 118 & & 126 & & & $27.5 \%$ & $6.60[-1.06,14.26]$ \\
\hline \multicolumn{8}{|c|}{ Heterogeneity: not applicable } \\
\hline \multicolumn{8}{|c|}{ Test for overall effect: $Z=1.69(P=0.09 \mid)$} \\
\hline \multicolumn{8}{|c|}{2 Zafirlukast 20 mg twice daily vs. Salmeterol 50 mcg twice daily } \\
\hline Nelson 2001 & 214 & $15(26.3)$ & 215 & $8(23.5)$ & & $72.5 \%$ & $7.00[2.28,11.72]$ \\
\hline Subtotal $(95 \%$ CI $)$ & 214 & & 215 & & & $72.5 \%$ & $7.00[2.28,11.72]$ \\
\hline \multicolumn{8}{|c|}{ Heterogeneity: not applicable } \\
\hline \multicolumn{8}{|c|}{ Test for overall effect: $Z=2.91(P=0.0037)$} \\
\hline Total $(95 \% \mathrm{CI})$ & 332 & & 341 & & & $100.0 \%$ & $6.89[2.87,10.91]$ \\
\hline \multicolumn{8}{|c|}{ Heterogeneity: Chi $^{2}=0.01, d f=I(P=0.93) ; 1^{2}=0.0 \%$} \\
\hline \multicolumn{8}{|c|}{ Test for overall effect: $Z=3.36(P=0.00078)$} \\
\hline \multicolumn{8}{|c|}{ Test for subgroup differences: $\mathrm{Chi}^{2}=0.0 \mathrm{I}, \mathrm{df}=\mathrm{I}(\mathrm{P}=0.93), \mathrm{I}^{2}=0.0 \%$} \\
\hline
\end{tabular}

Favours LTRA + ICS Favours LABA + ICS 
Analysis I.I7. Comparison I Long-acting B2-agonists + ICS versus leukotriene receptor antagonists + ICS, Outcome 17 Rescue-free nights (\%) - change from baseline.

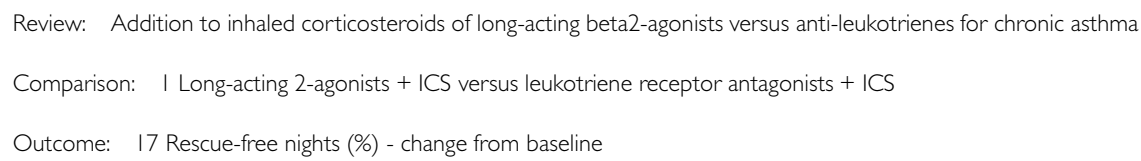

\section{Analysis I.18. Comparison I Long-acting B2-agonists + ICS versus leukotriene receptor antagonists + ICS,} Outcome 18 Withdrawals for any reason.

Review: Addition to inhaled corticosteroids of long-acting beta2-agonists versus anti-leukotrienes for chronic asthma

Comparison: I Long-acting 2-agonists + ICS versus leukotriene receptor antagonists + ICS

Outcome: 18 Withdrawals for any reason

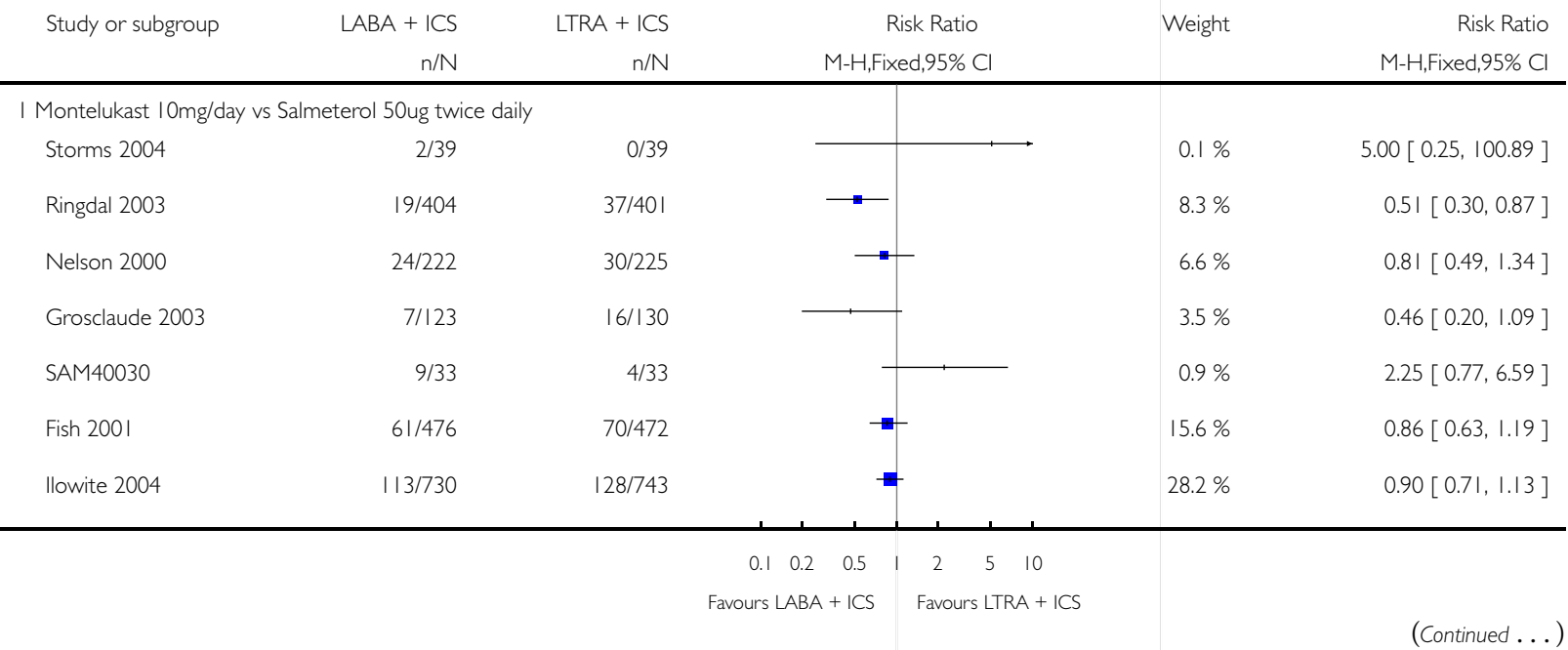




\begin{tabular}{|c|c|c|c|c|c|}
\hline \multirow[t]{2}{*}{ Study or subgroup } & $L A B A+I C S$ & LTRA + ICS & Risk Ratio & \multirow[t]{2}{*}{ Weight } & \multirow{2}{*}{$\begin{array}{r}\text { (. . . Continued }) \\
\text { Risk Ratio } \\
\text { M-H,Fixed,95\% Cl }\end{array}$} \\
\hline & $\mathrm{n} / \mathrm{N}$ & $\mathrm{n} / \mathrm{N}$ & M-H,Fixed,95\% Cl & & \\
\hline Bjermer 2003 & $110 / 743$ & $125 / 747$ & 贯 & $27.7 \%$ & $0.88[0.70,1.12]$ \\
\hline Pavord 2007 & 9/33 & $4 / 33$ & 7 & $0.9 \%$ & $2.25[0.77,6.59]$ \\
\hline Subtotal $(95 \% \mathrm{CI})$ & 2803 & 2823 & $\bullet$ & $91.8 \%$ & $0.86[0.76,0.98]$ \\
\hline \multicolumn{6}{|c|}{ Total events: 354 (LABA + ICS), 414 (LTRA + ICS) } \\
\hline \multicolumn{6}{|c|}{ Heterogeneity: $\mathrm{Ch}^{2}=|3.4|, d f=8(P=0.10) ; 1^{2}=40 \%$} \\
\hline \multicolumn{6}{|c|}{ Test for overall effect: $Z=2.22(P=0.026)$} \\
\hline \multicolumn{6}{|c|}{2 Zafirlukast $20 \mathrm{mg}$ twice daily vs Salmeterol $50 \mathrm{mcg}$ twice daily } \\
\hline Nelson 2001 & $12 / 214$ & $18 / 215$ & 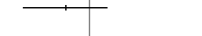 & $4.0 \%$ & $0.67[0.33,1.36]$ \\
\hline SD-004-0216 & $12 / 118$ & $19 / 118$ & - & $4.2 \%$ & $0.63[0.32,1.24]$ \\
\hline Subtotal $(95 \% \mathrm{CI})$ & 332 & 333 & - & $8.2 \%$ & $0.65[0.40,1.06]$ \\
\hline \multicolumn{6}{|c|}{ Total events: 24 (LABA + ICS), 37 (LTRA + ICS) } \\
\hline \multicolumn{6}{|c|}{ Heterogeneity: $C \mathrm{Ch}^{2}=0.0 \mathrm{I}, \mathrm{df}=\mathrm{I}(\mathrm{P}=0.91) ; \mathrm{I}^{2}=0.0 \%$} \\
\hline \multicolumn{6}{|c|}{ Test for overall effect: $Z=1.73(P=0.084)$} \\
\hline \multicolumn{6}{|c|}{3 Montelukast $10 \mathrm{mg} / \mathrm{d}$ versus Formoterol $18 \mathrm{mcg} / \mathrm{d}$} \\
\hline Subtotal $(95 \% \mathrm{CI})$ & $\mathbf{0}$ & $\mathbf{0}$ & & $0.0 \%$ & $0.0[0.0,0.0]$ \\
\hline \multicolumn{6}{|c|}{ Total events: 0 (LABA + ICS), 0 (LTRA + ICS) } \\
\hline \multicolumn{6}{|c|}{ Heterogeneity: not applicable } \\
\hline \multicolumn{6}{|c|}{ Test for overall effect: not applicable } \\
\hline Total $(95 \% \mathrm{CI})$ & 3135 & 3156 & • & $100.0 \%$ & $0.84[0.74,0.96]$ \\
\hline \multicolumn{6}{|c|}{ Total events: 378 (LABA + ICS), 45I (LTRA + ICS) } \\
\hline \multicolumn{6}{|c|}{ Heterogeneity: $\mathrm{Ch}^{2}=14.66, \mathrm{df}=10(P=0.14) ;\left.\right|^{2}=32 \%$} \\
\hline \multicolumn{6}{|c|}{ Test for overall effect: $Z=2.61(P=0.0089)$} \\
\hline Test for subgroup differen & ${ }^{2}=1.19, \mathrm{df}=$ & 27), $1^{2}=16 \%$ & & & \\
\hline
\end{tabular}

$\begin{array}{lllllll}0.1 & 0.2 & 0.5 & 1 & 2 & 5 & 10\end{array}$

Favours LABA + ICS Favours LTRA + ICS 
Analysis I.19. Comparison I Long-acting B2-agonists + ICS versus leukotriene receptor antagonists + ICS, Outcome 19 Withdrawals due to adverse events.

Review: Addition to inhaled corticosteroids of long-acting beta2-agonists versus anti-leukotrienes for chronic asthma

Comparison: I Long-acting 2-agonists + ICS versus leukotriene receptor antagonists + ICS

Outcome: 19 Withdrawals due to adverse events

$\begin{array}{llll}\text { Study or subgroup } & \text { LABA + ICS } & \text { LTRA + ICS } & \text { Risk Ratio }\end{array}$

$\mathrm{n} / \mathrm{N}$

M-H,Fixed,95\% C

$\mathrm{M}-\mathrm{H}$, Fixed,95\% Cl

\begin{tabular}{|c|c|c|c|c|c|}
\hline \multicolumn{6}{|c|}{ I Montelukast 10 mg once daily versus Salmeterol 50 mcg twice daily } \\
\hline Storms 2004 & $1 / 39$ & 0/39 & & $0.4 \%$ & $3.00[0.13,71.46]$ \\
\hline Fish 2001 & $13 / 476$ & $13 / 472$ & & $11.0 \%$ & $0.99[0.46,2.12]$ \\
\hline Nelson 2000 & $6 / 222$ & $4 / 225$ & & $3.3 \%$ & $1.52[0.43,5.31]$ \\
\hline Grosclaude 2003 & $3 / 123$ & $5 / 130$ & & $4.1 \%$ & $0.63[0.15,2.60]$ \\
\hline SAM40030 & $2 / 33$ & $4 / 33$ & & $3.4 \%$ & $0.50[0.10,2.55]$ \\
\hline Ringdal 2003 & $13 / 404$ & $|9 / 40|$ & & $16.0 \%$ & $0.68[0.34,1.36]$ \\
\hline llowite 2004 & $32 / 730$ & $20 / 743$ & 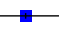 & $16.6 \%$ & $1.63[0.94,2.82]$ \\
\hline Bjermer 2003 & $36 / 743$ & $38 / 747$ & & $31.8 \%$ & $0.95[0.61,1.49]$ \\
\hline Pavord 2007 & $2 / 33$ & $4 / 33$ & & $3.4 \%$ & $0.50[0.10,2.55]$ \\
\hline Subtotal (95\% CI) & 2803 & 2823 & & $89.9 \%$ & $1.02[0.78,1.32]$ \\
\hline \multicolumn{6}{|c|}{ Total events: 108 (LABA + ICS), 107 (LTRA + ICS) } \\
\hline \multicolumn{6}{|c|}{ Heterogeneity: $\mathrm{Chi}^{2}=6.96, \mathrm{df}=8(\mathrm{P}=0.54) ;\left.\right|^{2}=0.0 \%$} \\
\hline \multicolumn{6}{|c|}{ Test for overall effect: $Z=0.12(P=0.91)$} \\
\hline \multicolumn{6}{|c|}{2 Zafirlukast 20 mg twice daily vs. Salmeterol 50 mcg twice daily } \\
\hline Nelson 2001 & $7 / 214$ & $7 / 215$ & & $5.9 \%$ & $1.00[0.36,2.82]$ \\
\hline SD-004-0216 & $4 / 118$ & $5 / 118$ & & $4.2 \%$ & $0.80[0.22,2.91]$ \\
\hline Subtotal (95\% CI) & 332 & 333 & & $10.1 \%$ & $0.92[0.41,2.05]$ \\
\hline \multicolumn{6}{|c|}{ Total events: II (LABA + ICS), I2 (LTRA + ICS) } \\
\hline \multicolumn{6}{|c|}{ Heterogeneity: $\mathrm{Chi}^{2}=0.07, \mathrm{df}=\mathrm{I}(\mathrm{P}=0.79) ; \mathrm{I}^{2}=0.0 \%$} \\
\hline \multicolumn{6}{|c|}{ Test for overall effect: $Z=0.21(P=0.84)$} \\
\hline Total $(95 \% \mathrm{CI})$ & 3135 & 3156 & & $100.0 \%$ & $1.01[0.79,1.29]$ \\
\hline \multicolumn{6}{|c|}{ Total events: II9 (LABA + ICS), I19 (LTRA + ICS) } \\
\hline \multicolumn{6}{|c|}{ Heterogeneity: Chi $^{2}=7.08, d f=10(P=0.72) ;\left.\right|^{2}=0.0 \%$} \\
\hline \multicolumn{6}{|c|}{ Test for overall effect: $Z=0.05(P=0.96)$} \\
\hline Test for subgroup differen & $.05 \mathrm{df}$ & $=0.0 \%$ & & & \\
\hline
\end{tabular}

$\begin{array}{lllllll}0.1 & 0.2 & 0.5 & 1 & 2 & 5 & 10\end{array}$

Favours LABA + ICS Favours LTRA + ICS 
Analysis I.20. Comparison I Long-acting B2-agonists + ICS versus leukotriene receptor antagonists + ICS, Outcome 20 Withdrawals due to poor asthma control/asthma exacerbation.

Review: Addition to inhaled corticosteroids of long-acting beta2-agonists versus anti-leukotrienes for chronic asthma

Comparison: I Long-acting 2-agonists + ICS versus leukotriene receptor antagonists + ICS

Outcome: 20 Withdrawals due to poor asthma control/asthma exacerbation

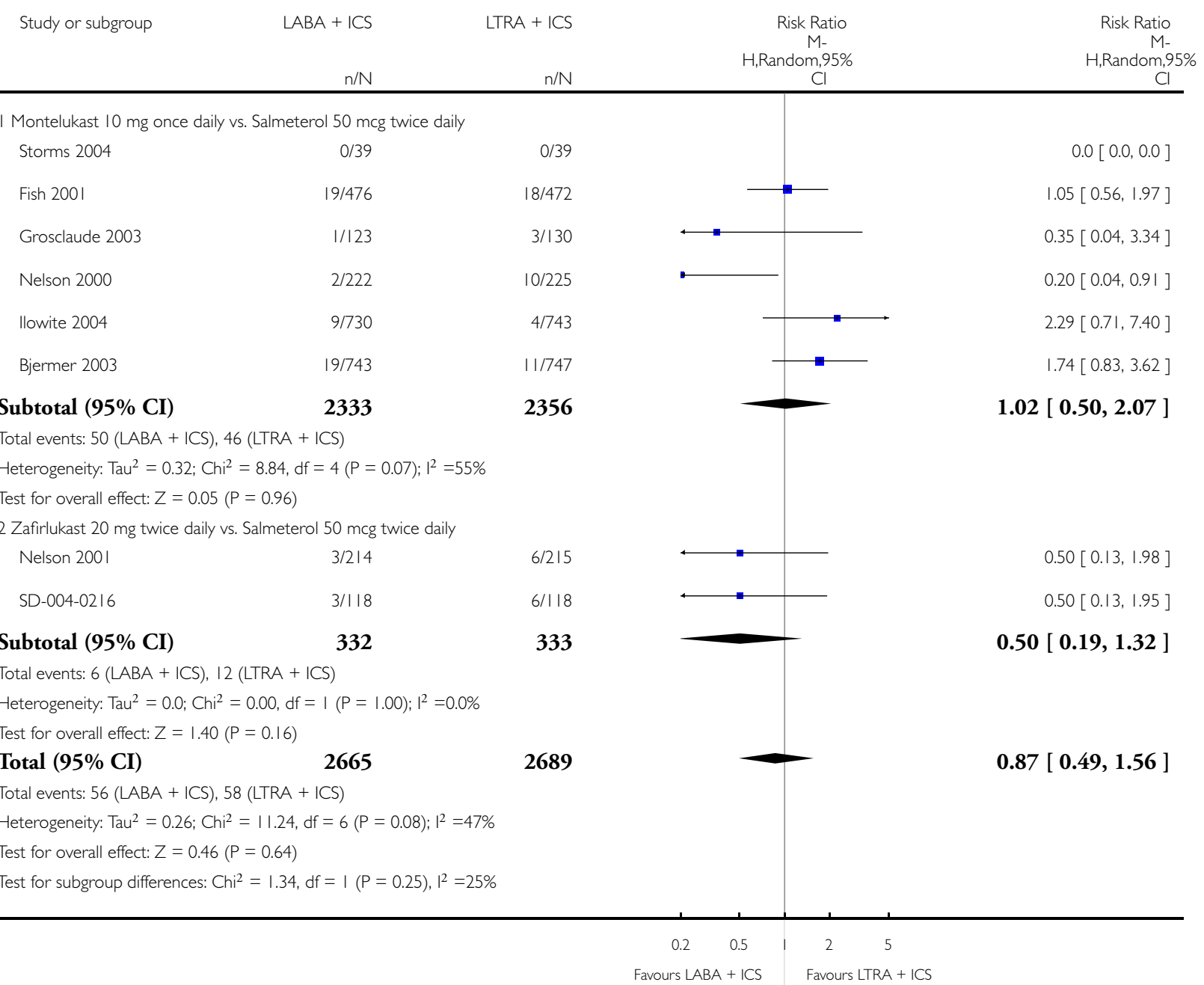


Analysis I.2I. Comparison I Long-acting B2-agonists + ICS versus leukotriene receptor antagonists + ICS, Outcome 2 I Patients with one or more exacerbations requiring hospital admission.

Review: Addition to inhaled corticosteroids of long-acting beta2-agonists versus anti-leukotrienes for chronic asthma

Comparison: I Long-acting 2-agonists + ICS versus leukotriene receptor antagonists + ICS

Outcome: 21 Patients with one or more exacerbations requiring hospital admission

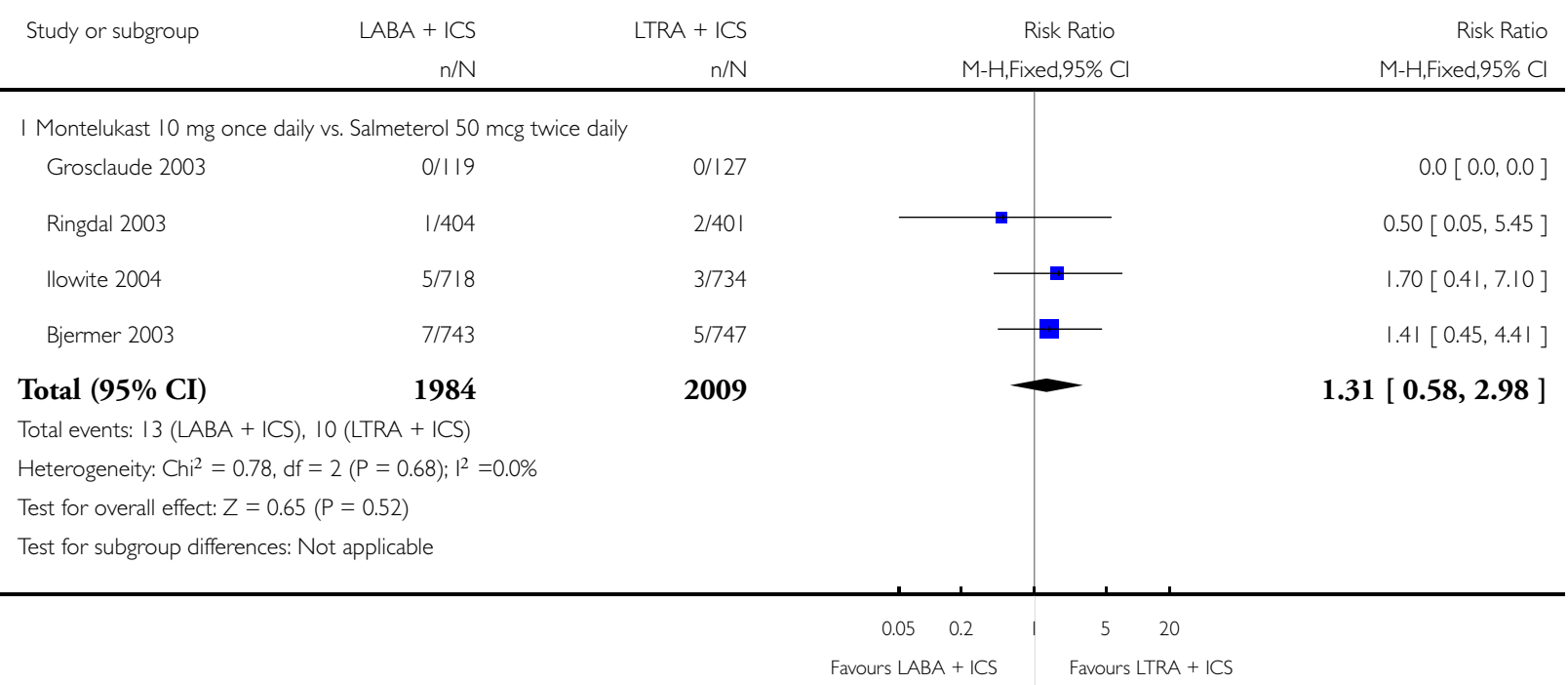


Analysis I.22. Comparison I Long-acting B2-agonists + ICS versus leukotriene receptor antagonists + ICS, Outcome 22 Serious Adverse events.

Review: Addition to inhaled corticosteroids of long-acting beta2-agonists versus anti-leukotrienes for chronic asthma

Comparison: I Long-acting 2-agonists + ICS versus leukotriene receptor antagonists + ICS

Outcome: 22 Serious Adverse events

\begin{tabular}{|c|c|c|c|c|c|}
\hline \multirow[t]{2}{*}{ Study or subgroup } & $L A B A+I C S$ & LTRA + ICS & Risk Ratio & \multirow[t]{2}{*}{ Weight } & Risk Ratio \\
\hline & $\mathrm{n} / \mathrm{N}$ & $\mathrm{n} / \mathrm{N}$ & M-H,Fixed,95\% Cl & & M-H,Fixed,95\% Cl \\
\hline \multicolumn{6}{|c|}{ I Montelukast 10 mg once daily vs. Salmeterol 50 mcg twice daily } \\
\hline Fish 2001 & $5 / 476$ & $5 / 472$ & 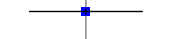 & $7.0 \%$ & $0.99[0.29,3.40]$ \\
\hline Ringdal 2003 & $4 / 404$ & $7 / 401$ & $=-1$ & $9.9 \%$ & $0.57[0.17,1.92]$ \\
\hline Nelson 2000 & $1 / 222$ & $2 / 225$ & & $2.8 \%$ & $0.51[0.05,5.55]$ \\
\hline llowite 2004 & $27 / 730$ & $22 / 743$ & - & $30.6 \%$ & $1.25[0.72,2.17]$ \\
\hline Bjermer 2003 & $55 / 743$ & $34 / 747$ & + & $47.6 \%$ & $1.63[1.07,2.46]$ \\
\hline Pavord 2007 & $2 / 33$ & $0 / 33$ & & $0.7 \%$ & $5.00[0.25,100.32]$ \\
\hline
\end{tabular}

Subtotal (95\% CI)

2608

Total events: 94 (LABA + ICS), 70 (LTRA + ICS)

Heterogeneity: $\mathrm{Chi}^{2}=4.40, \mathrm{df}=5(\mathrm{P}=0.49) ; \mathrm{I}^{2}=0.0 \%$

Test for overall effect: $Z=1.95(P=0.05 \mathrm{I})$

2 Zafirlukast $20 \mathrm{mg}$ twice daily vs. Salmeterol $50 \mathrm{mcg}$ twice daily Nelson 2001

$1 / 2 \mid 4$

Subtotal (95\% CI)

214

Total events: I (LABA + ICS), I (LTRA + ICS)

Heterogeneity: not applicable

Test for overall effect: $Z=0.00(P=1.0)$

Total (95\% CI)

2822

Total events: 95 (LABA + ICS), 7 I (LTRA + ICS)

Heterogeneity: $\mathrm{Chi}^{2}=4.45, \mathrm{df}=6(\mathrm{P}=0.62) ; \mathrm{I}^{2}=0.0 \%$

Test for overall effect: $Z=1.94(P=0.053)$

Test for subgroup differences: $\mathrm{Chi}^{2}=0.04, \mathrm{df}=\mathrm{I}(\mathrm{P}=0.83), \mathrm{I}^{2}=0.0 \%$

2621

$98.6 \%$

$1.35[1.00,1.83]$

215

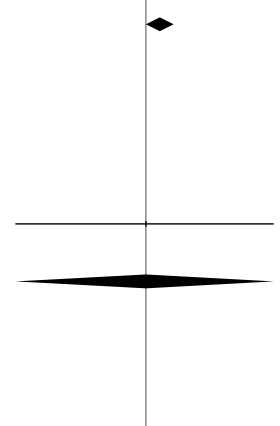

$1.4 \%$

$1.00[0.06,15.96]$

$1.4 \%$

$1.00[0.06,15.96$ ]

2836

$100.0 \%$

$1.35[1.00,1.82]$

$\begin{array}{ccccc}0.05 & 0.2 & 1 & 5 & 20 \\ \text { Favours LABA + ICS } & & \text { Favours LTRA + ICS }\end{array}$


Analysis I.23. Comparison I Long-acting B2-agonists + ICS versus leukotriene receptor antagonists + ICS, Outcome 23 Death.

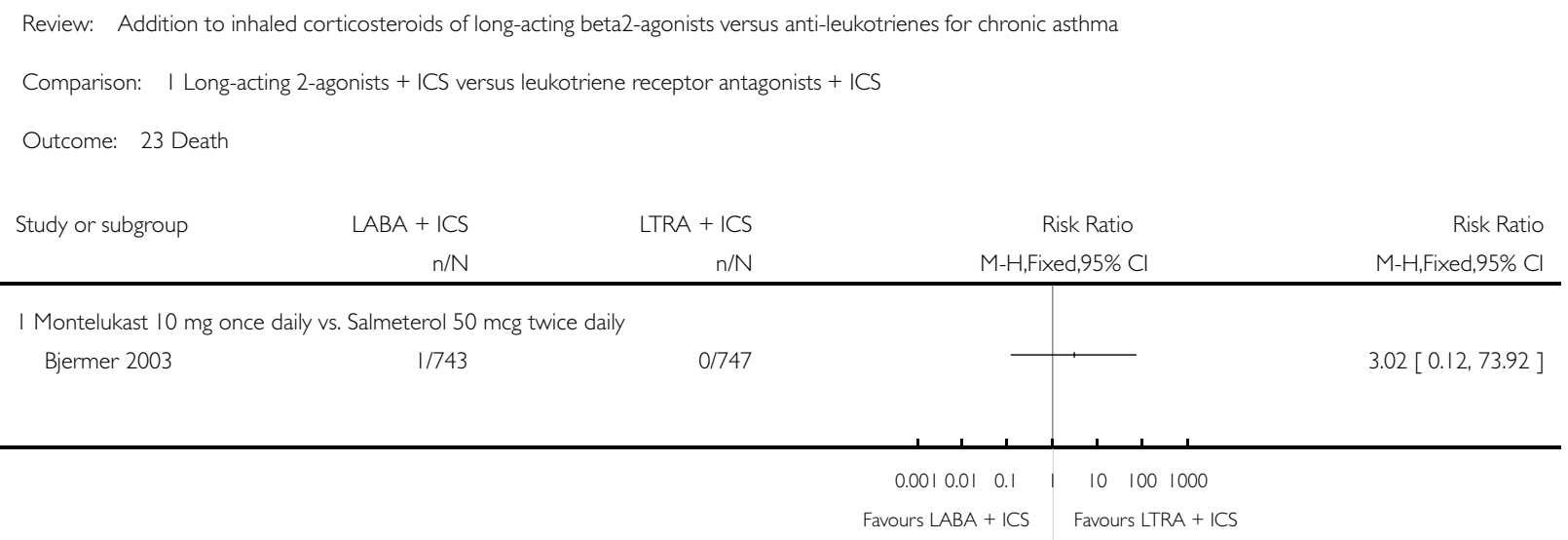

Analysis 1.24. Comparison I Long-acting B2-agonists + ICS versus leukotriene receptor antagonists + ICS, Outcome 24 Headache.

Review: Addition to inhaled corticosteroids of long-acting beta2-agonists versus anti-leukotrienes for chronic asthma

Comparison: I Long-acting 2-agonists + ICS versus leukotriene receptor antagonists + ICS

Outcome: 24 Headache

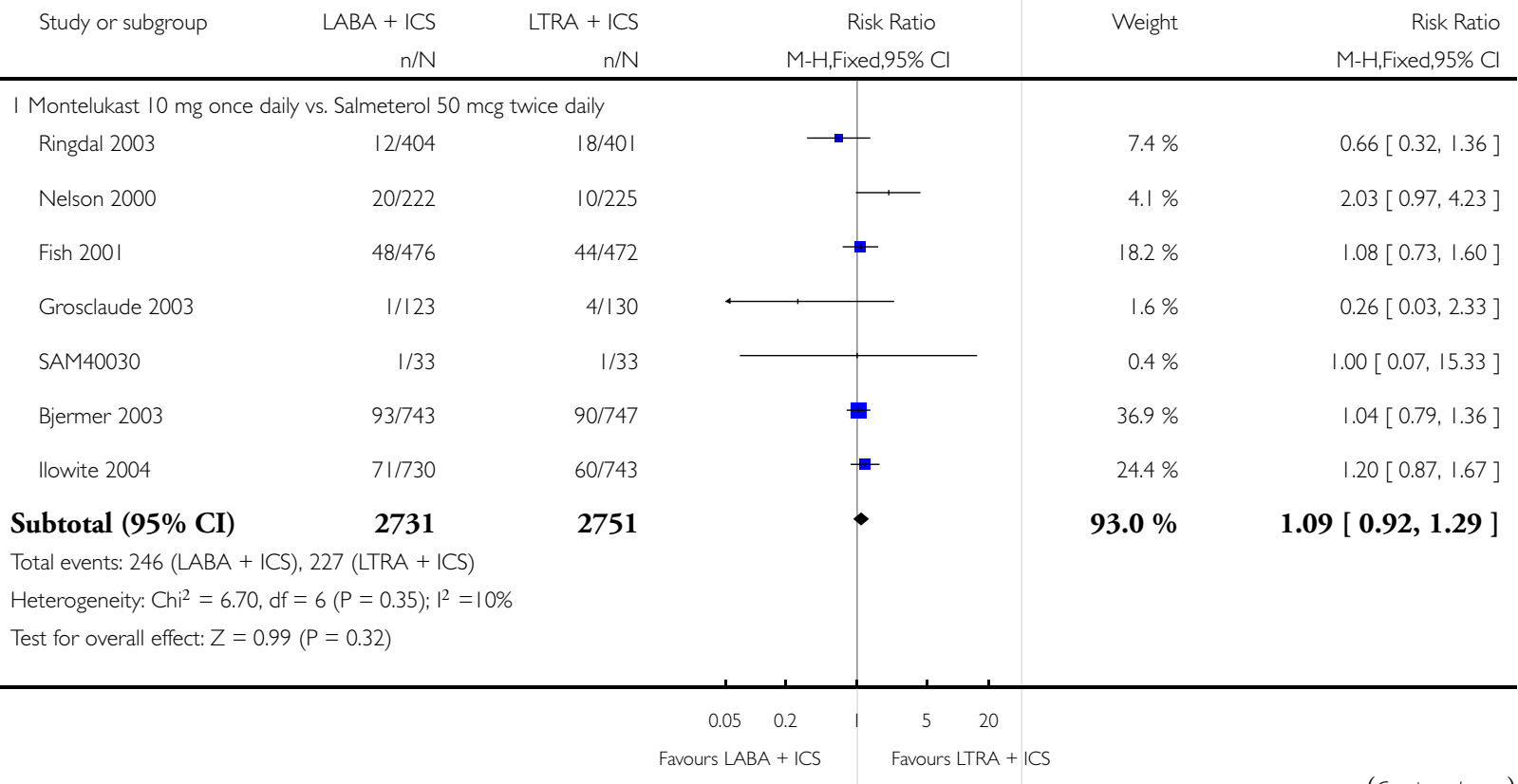

(Continued ...) 


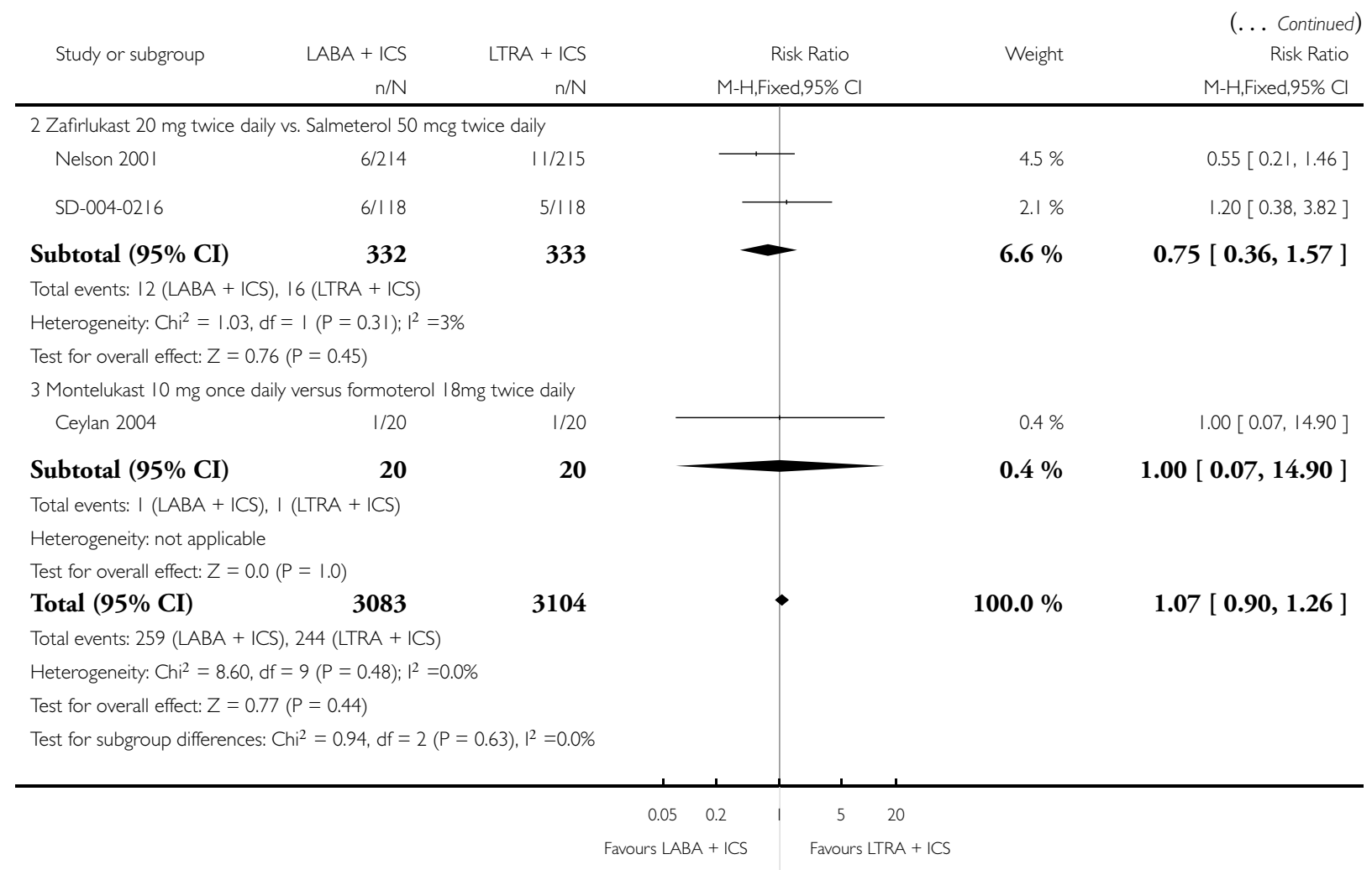


Analysis I.25. Comparison I Long-acting B2-agonists + ICS versus leukotriene receptor antagonists + ICS, Outcome 25 Cardiovascular events.

Review: Addition to inhaled corticosteroids of long-acting beta2-agonists versus anti-leukotrienes for chronic asthma

Comparison: I Long-acting 2-agonists + ICS versus leukotriene receptor antagonists + ICS

Outcome: 25 Cardiovascular events

$\begin{array}{llll}\text { Study or subgroup } & \text { LABA + ICS } & \text { LTRA + ICS } & \text { Risk Ratio }\end{array}$

$n / N \quad n / N \quad M-H, F i x e d, 95 \%$ Cl $\quad M-H, F i x e d, 95 \%$ Cl

I Montelukast $10 \mathrm{mg}$ once daily vs. Salmeterol $50 \mathrm{mcg}$ twice daily

Fish 2001 $\quad 4 / 476 \quad 8 / 472$

Ringdal $2003 \quad 6 / 404 \quad 9 / 40$ ।

$\begin{array}{lll}\text { Nelson } 2000 & 3 / 222 & 1 / 225\end{array}$

$\begin{array}{lll}\text { Howite } 2004 & \text { 22/730 } & \text { 18/743 }\end{array}$

Bjermer $2003 \quad 31 / 743 \quad 25 / 747$

$0.50[0.15,1.64]$

Total (95\% CI)

2575

2588

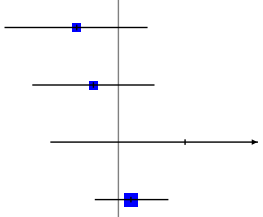

$13.2 \%$

$0.50[0.15,1.64]$

Total events: 66 (LABA + ICS), 6 I (LTRA + ICS)

Heterogeneity: $\mathrm{Chi}^{2}=3.82, \mathrm{df}=4(\mathrm{P}=0.43) ; \mathrm{I}^{2}=0.0 \%$

Test for overall effect: $Z=0.49(P=0.63)$

Test for subgroup differences: Not applicable

$0.1 \quad 0.20 .5 \quad 1 \quad 2 \quad 5 \quad 10$

Favours LABA + ICS Favours LTRA + ICS 
Analysis I.26. Comparison I Long-acting B2-agonists + ICS versus leukotriene receptor antagonists + ICS, Outcome 26 Oral moniliasis.

Review: Addition to inhaled corticosteroids of long-acting beta2-agonists versus anti-leukotrienes for chronic asthma

Comparison: I Long-acting 2-agonists + ICS versus leukotriene receptor antagonists + ICS

Outcome: 26 Oral moniliasis

$\begin{array}{llll}\text { Study or subgroup } & \text { LABA + ICS } & \text { LTRA + ICS } & \text { Risk Ratio }\end{array}$

$\mathrm{n} / \mathrm{N} \quad \mathrm{n} / \mathrm{N} \quad \mathrm{M}-\mathrm{H}, \mathrm{Fixed}, 95 \% \mathrm{Cl} \quad \mathrm{M}-\mathrm{H}, \mathrm{Fixed}, 95 \% \mathrm{Cl}$

I Montelukast $10 \mathrm{mg}$ once daily vs. Salmeterol $50 \mathrm{mcg}$ twice daily

Fish 2001 1/476 0/472

$\begin{array}{lll}\text { Nelson } 2000 & \text { 3/222 }\end{array}$

Ringdal $2003 \quad 3 / 404 \quad$ |/40|

Howite $2004 \quad$ 6/743
13/730

Bjermer $2003 \quad 7 / 743 \quad 3 / 747$

Subtotal (95\% CI) $\quad 2575 \quad 2588$

Total events: 27 (LABA + ICS), 14 (LTRA + ICS)

Heterogeneity: Chi $^{2}=1.88, \mathrm{df}=4(\mathrm{P}=0.76) ; \mathrm{I}^{2}=0.0 \%$

Test for overall effect: $Z=2.01(P=0.044)$

2 Montelukast $10 \mathrm{mg}$ once daily versus formoterol $18 \mathrm{mg}$ twice daily

Ceylan 2004

$1 / 20$

Subtotal (95\% CI)

20

Total events: I (LABA + ICS), I (LTRA + ICS)

Heterogeneity: not applicable

Test for overall effect: $Z=0.0(P=1.0)$

Total (95\% CI)

2595

$\mathrm{M}-\mathrm{H}, \mathrm{FI} \mathrm{Xed}, 95 \% \mathrm{Cl}$

$\mathrm{M}-\mathrm{H}, \mathrm{FI} \mathbf{x e d}, 95 \% \mathrm{Cl}$

Total events: 28 (LABA + ICS), 15 (LTRA + ICS)

Heterogeneity: $\mathrm{Chi}^{2}=2.08, \mathrm{df}=5(\mathrm{P}=0.84) ; \mathrm{I}^{2}=0.0 \%$

Test for overall effect: $Z=1.97(P=0.049)$

Test for subgroup differences: $\mathrm{Chi}^{2}=0.2 \mathrm{l}, \mathrm{df}=\mathrm{I}(\mathrm{P}=0.65), \mathrm{I}^{2}=0.0 \%$

I/20

20

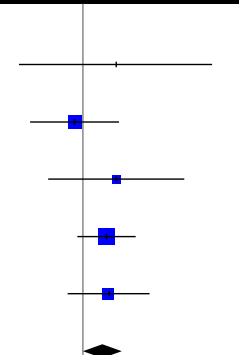

$3.3 \%$

$25.8 \%$

$6.5 \%$

$38.6 \%$

$19.4 \%$

$93.5 \%$

$1.00[0.07,14.90]$

$6.5 \%$

$1.00[0.07,14.90]$

2608

$100.0 \%$

$1.86[1.00,3.44]$

$0.76[0.17,3.36]$

$2.98[0.31,28.51]$

$2.21[0.84,5.77]$

$2.35[0.61,9.04]$

$1.92[1.02,3.61]$
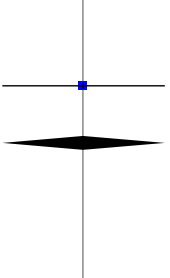
Analysis I.27. Comparison I Long-acting B2-agonists + ICS versus leukotriene receptor antagonists + ICS, Outcome 27 Osteopenia/osteoporosis.

Review: Addition to inhaled corticosteroids of long-acting beta2-agonists versus anti-leukotrienes for chronic asthma

Comparison: I Long-acting 2-agonists + ICS versus leukotriene receptor antagonists + ICS

Outcome: 27 Osteopenia/osteoporosis

\begin{tabular}{|c|c|c|c|c|c|}
\hline \multirow[t]{2}{*}{ Study or subgroup } & $L A B A+I C S$ & LTRA + ICS & Risk Ratio & \multirow[t]{2}{*}{ Weight } & \multirow{2}{*}{$\begin{array}{r}\text { Risk Ratio } \\
\text { M-H,Fixed,95\% Cl } \\
\end{array}$} \\
\hline & $n / N$ & $\mathrm{n} / \mathrm{N}$ & M-H,Fixed,95\% Cl & & \\
\hline \multicolumn{6}{|c|}{ I Montelukast $10 \mathrm{mg}$ once daily vs. Salmeterol 50 mcg twice daily } \\
\hline llowite 2004 & $0 / 730$ & $1 / 743$ & 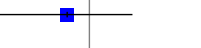 & $33.2 \%$ & $0.34[0.01,8.31]$ \\
\hline Bjermer 2003 & $2 / 743$ & $3 / 747$ & & $66.8 \%$ & $0.67[0.11,4.00]$ \\
\hline Total $(95 \% \mathrm{CI})$ & 1473 & 1490 & & $100.0 \%$ & $0.56[0.12,2.63]$ \\
\hline \multicolumn{6}{|c|}{ Total events: 2 (LABA + ICS), 4 (LTRA + ICS) } \\
\hline \multicolumn{6}{|c|}{ Heterogeneity: Chi $^{2}=0.13, d f=|(P=0.72) ;|^{2}=0.0 \%$} \\
\hline \multicolumn{6}{|c|}{ Test for overall effect: $Z=0.73(P=0.46)$} \\
\hline Test for subgroup diffe & Vot applicable & & & & \\
\hline
\end{tabular}

$0.0010 .010 .1 \quad 1 \quad 10 \quad 1001000$

Favours LABA + ICS Favours LTRA + ICS

Analysis I.28. Comparison I Long-acting B2-agonists + ICS versus leukotriene receptor antagonists + ICS, Outcome 28 Elevated liver enzymes.

Review: Addition to inhaled corticosteroids of long-acting beta2-agonists versus anti-leukotrienes for chronic asthma

Comparison: I Long-acting 2-agonists + ICS versus leukotriene receptor antagonists + ICS

Outcome: 28 Elevated liver enzymes

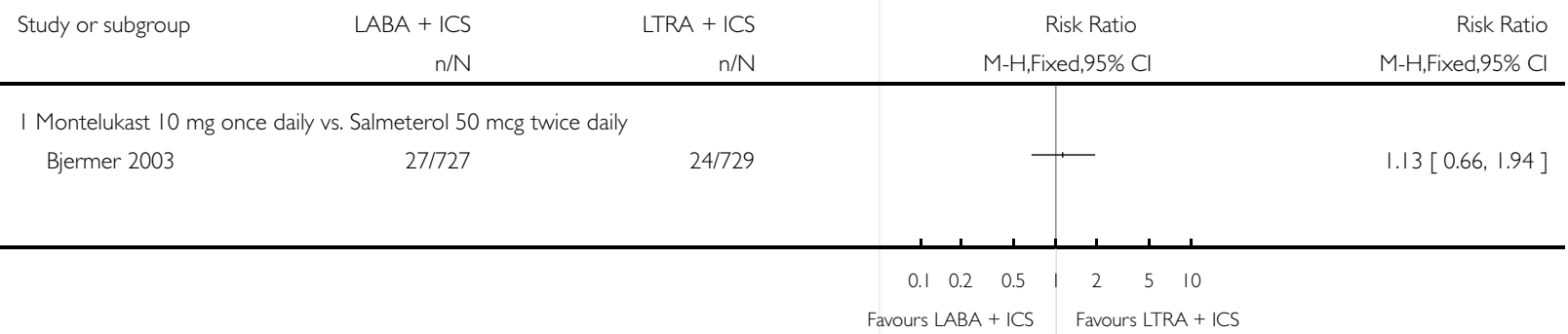


Analysis I.29. Comparison I Long-acting B2-agonists + ICS versus leukotriene receptor antagonists + ICS, Outcome 29 Overall adverse events.

Review: Addition to inhaled corticosteroids of long-acting beta2-agonists versus anti-leukotrienes for chronic asthma

Comparison: I Long-acting 2-agonists + ICS versus leukotriene receptor antagonists + ICS

Outcome: 29 Overall adverse events

$\begin{array}{llll}\text { Study or subgroup } & \text { LABA + ICS } & \text { LTRA + ICS } & \text { Risk Ratio }\end{array}$

$\mathrm{n} / \mathrm{N}$

M-H,Fixed,95\% C

M-H,Fixed,95\% Cl

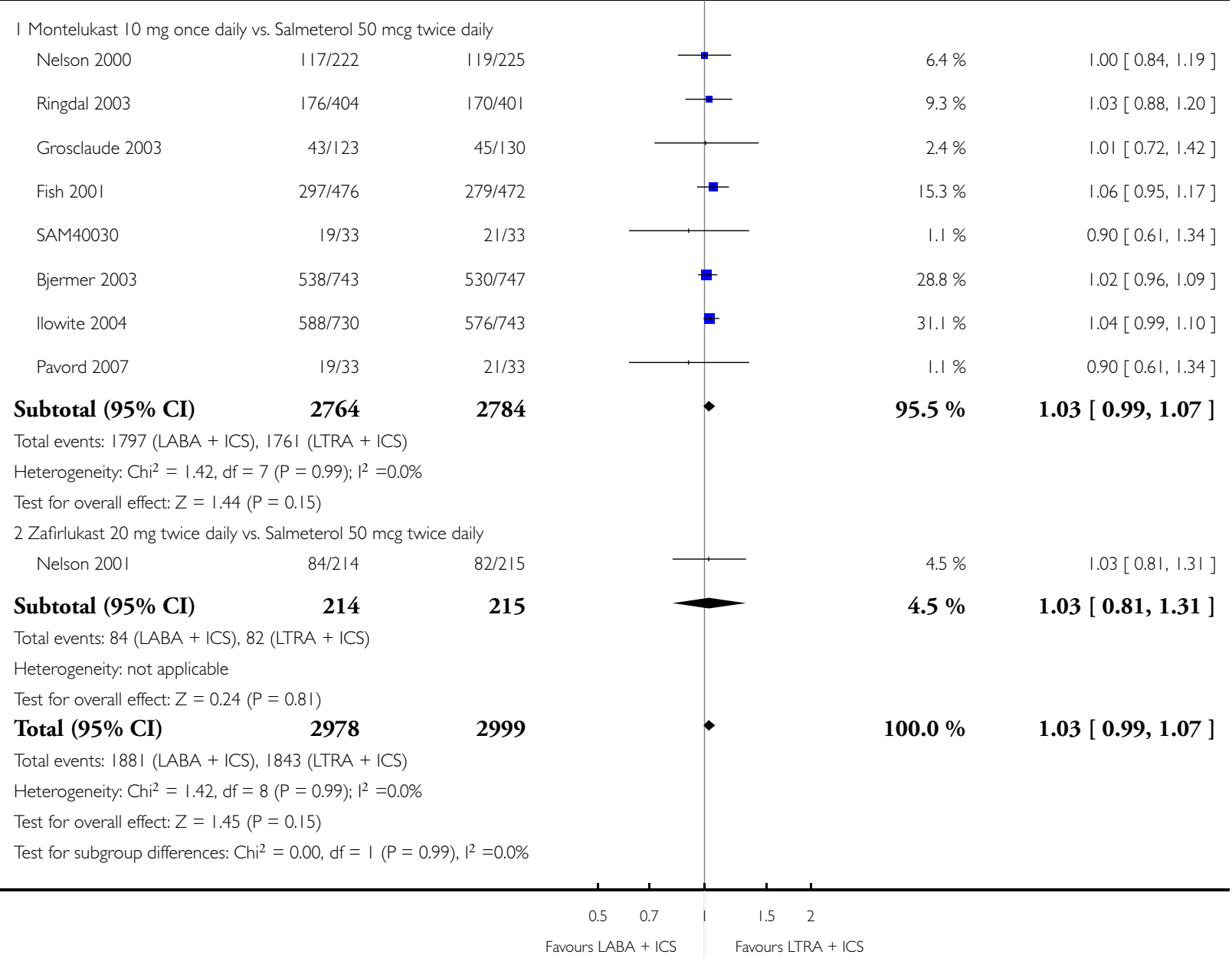

Addition to inhaled corticosteroids of long-acting beta2-agonists versus anti-leukotrienes for chronic asthma (Review) 
Analysis I.30. Comparison I Long-acting B2-agonists + ICS versus leukotriene receptor antagonists + ICS, Outcome 30 Patient treatment satisfaction.

Review: Addition to inhaled corticosteroids of long-acting beta2-agonists versus anti-leukotrienes for chronic asthma

Comparison: I Long-acting 2-agonists + ICS versus leukotriene receptor antagonists + ICS

Outcome: 30 Patient treatment satisfaction

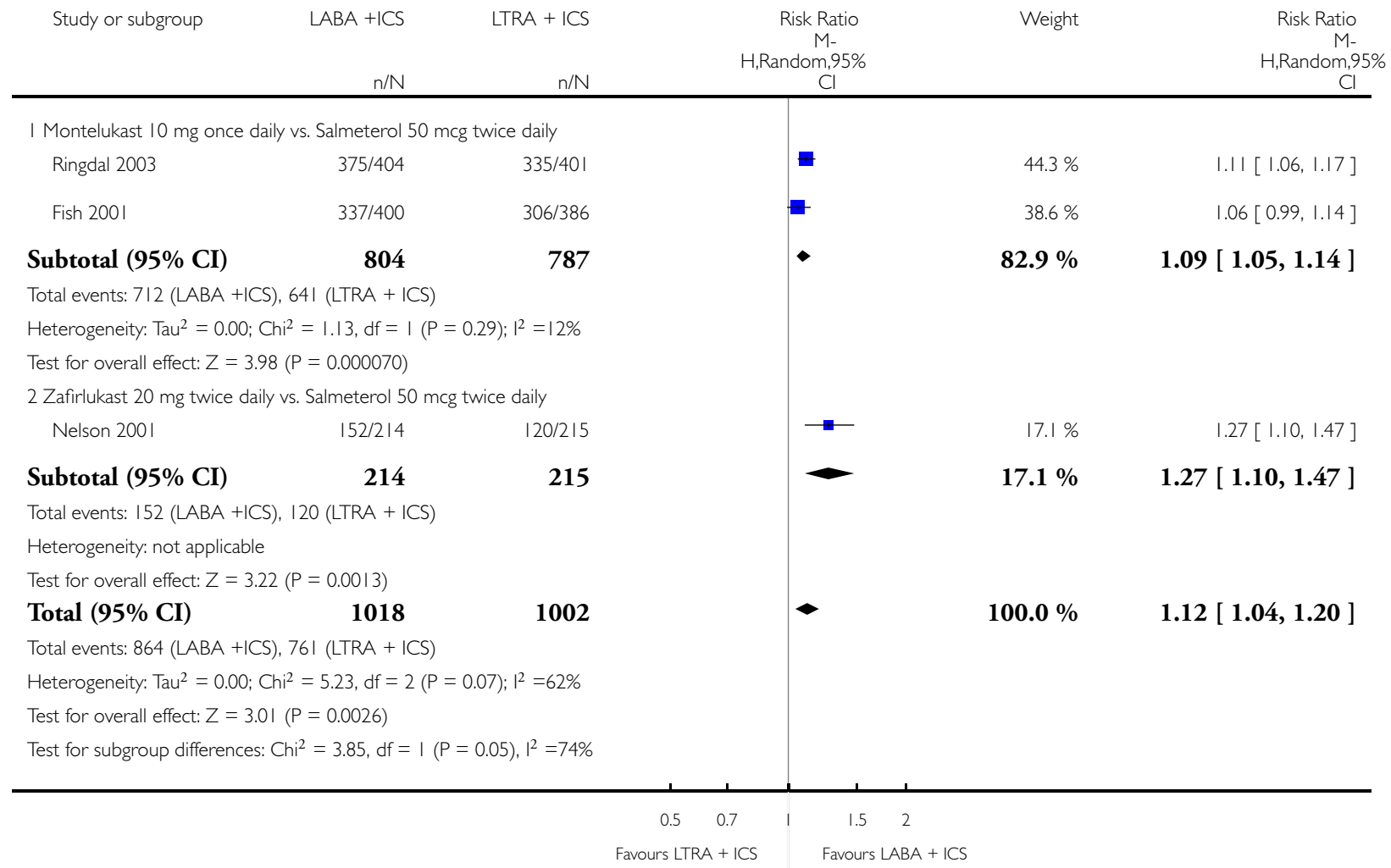


Analysis I.3 I. Comparison I Long-acting B2-agonists + ICS versus leukotriene receptor antagonists + ICS, Outcome 31 Change from baseline in serum eosinophils (x I0e9/L).

Review: Addition to inhaled corticosteroids of long-acting beta2-agonists versus anti-leukotrienes for chronic asthma

Comparison: I Long-acting 2-agonists + ICS versus leukotriene receptor antagonists + ICS

Outcome: 31 Change from baseline in serum eosinophils $(\times 10 \mathrm{e} 9 / \mathrm{L})$

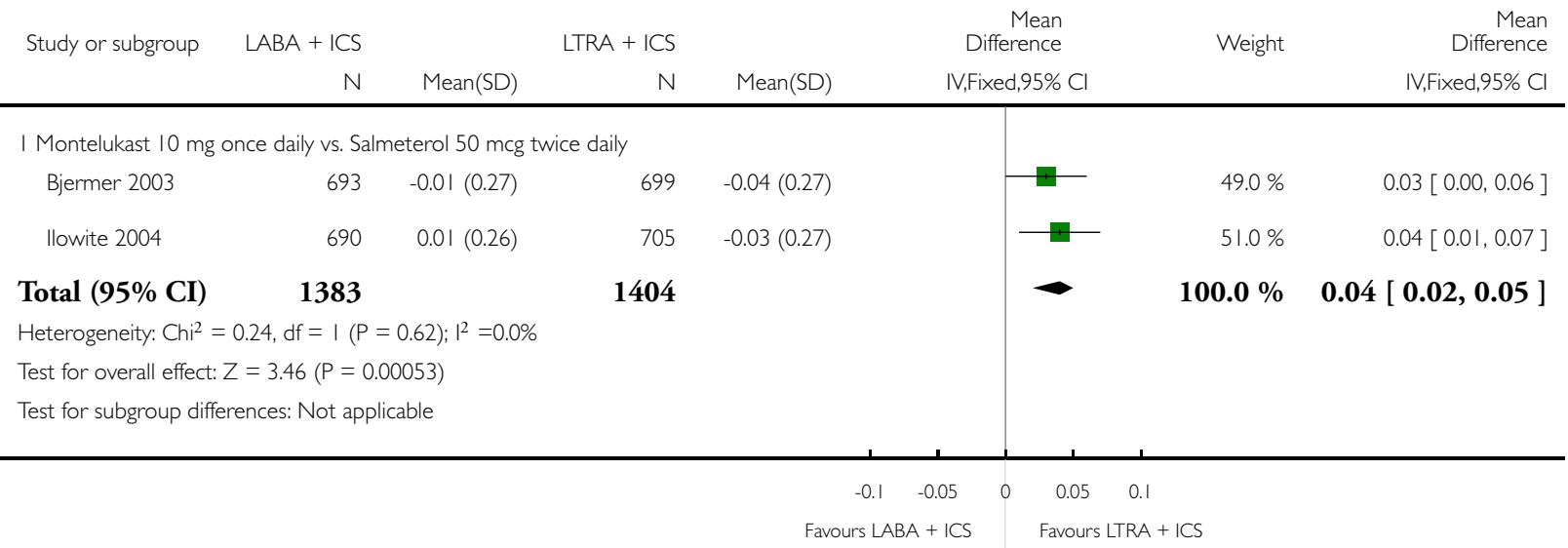


Analysis 2.I. Comparison 2 Subgroup and sensitivity analyses, Outcome I Participants with one or more exacerbations requiring systemic corticosteroids: number of inhaler devices.

Review: Addition to inhaled corticosteroids of long-acting beta2-agonists versus anti-leukotrienes for chronic asthma

Comparison: 2 Subgroup and sensitivity analyses

Outcome: I Participants with one or more exacerbations requiring systemic corticosteroids: number of inhaler devices

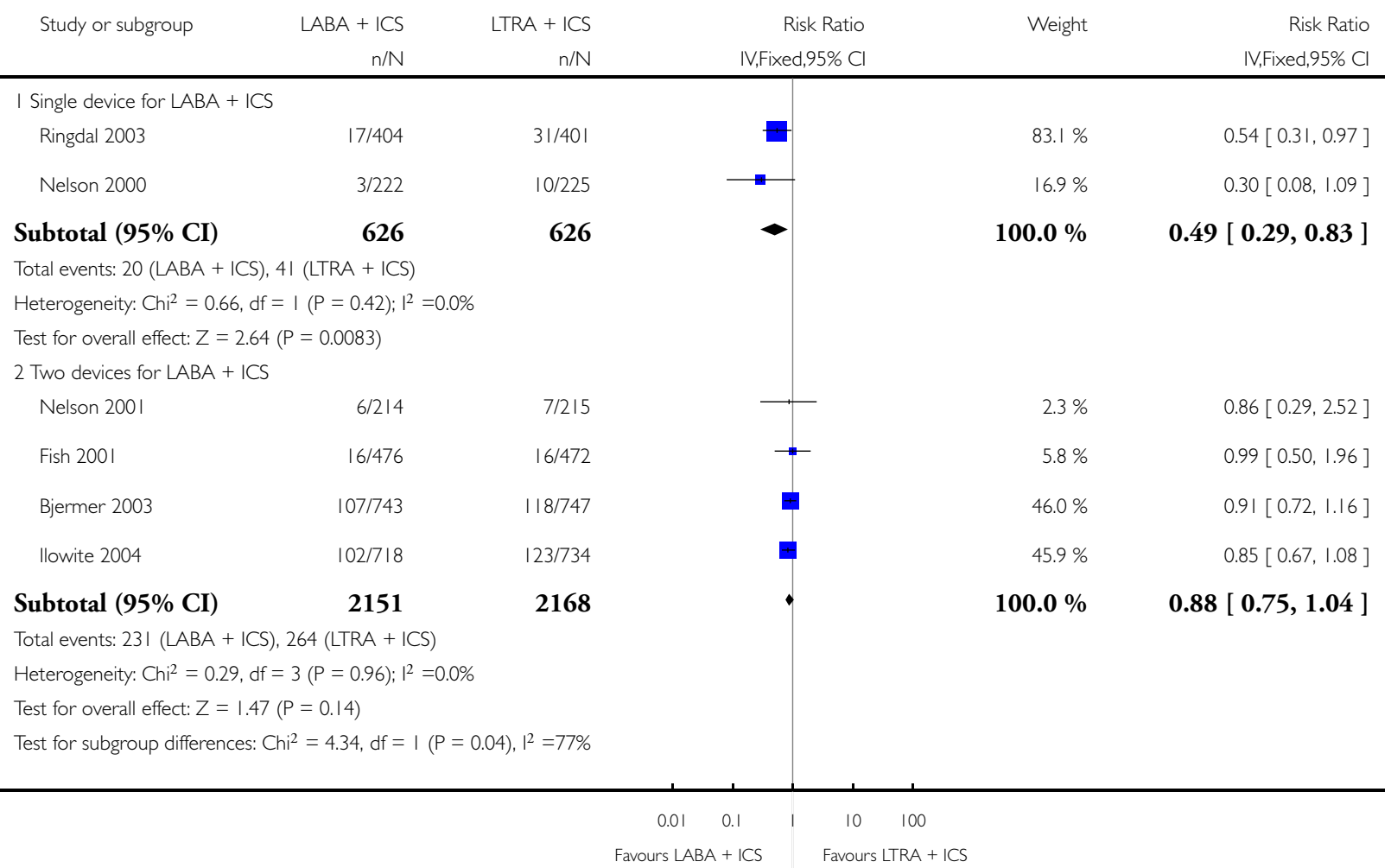


Analysis 2.2. Comparison 2 Subgroup and sensitivity analyses, Outcome 2 Participants with one or more exacerbations requiring systemic corticosteroids: dose of ICS.

Review: Addition to inhaled corticosteroids of long-acting beta2-agonists versus anti-leukotrienes for chronic asthma

Comparison: 2 Subgroup and sensitivity analyses

Outcome: 2 Participants with one or more exacerbations requiring systemic corticosteroids: dose of ICS

\begin{tabular}{|c|c|c|c|c|c|}
\hline \multirow[t]{2}{*}{ Study or subgroup } & $L A B A+I C S$ & LTRA + ICS & \multirow{2}{*}{$\begin{array}{c}\text { Risk Ratio } \\
\text { M-H,Fixed,95\% Cl }\end{array}$} & \multirow[t]{2}{*}{ Weight } & \multirow{2}{*}{$\begin{array}{r}\text { Risk Ratio } \\
\text { M-H,Fixed,95\% Cl }\end{array}$} \\
\hline & $\mathrm{n} / \mathrm{N}$ & $\mathrm{n} / \mathrm{N}$ & & & \\
\hline \multicolumn{6}{|l|}{ I Low dose of ICS } \\
\hline Bjermer 2003 & 107/743 & $118 / 747$ & & $74.1 \%$ & $0.91[0.72,1.16]$ \\
\hline Nelson 2000 & $3 / 222$ & $10 / 225$ & 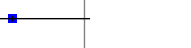 & $6.3 \%$ & $0.30[0.08,1.09]$ \\
\hline Ringdal 2003 & $17 / 404$ & $31 / 401$ & $\longrightarrow$ & $19.6 \%$ & $0.54[0.31,0.97]$ \\
\hline Subtotal (95\% CI) & 1369 & 1373 & 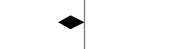 & $100.0 \%$ & $0.80[0.64,1.00]$ \\
\hline \multicolumn{6}{|c|}{ Total events: I27 (LABA + ICS), I59 (LTRA + ICS) } \\
\hline \multicolumn{6}{|c|}{ Heterogeneity: Chi $^{2}=5.05, \mathrm{df}=2(P=0.08) ; \mathrm{I}^{2}=60 \%$} \\
\hline \multicolumn{6}{|c|}{ Test for overall effect: $Z=1.99(P=0.047)$} \\
\hline \multicolumn{6}{|l|}{2 Medium dose of ICS } \\
\hline llowite 2004 & $102 / 718$ & $123 / 734$ & & $100.0 \%$ & $0.85[0.67,1.08]$ \\
\hline Subtotal (95\% CI) & 718 & 734 & & $100.0 \%$ & $0.85[0.67,1.08]$ \\
\hline \multicolumn{6}{|c|}{ Total events: 102 (LABA + ICS), 123 (LTRA + ICS) } \\
\hline \multicolumn{6}{|c|}{ Heterogeneity: not applicable } \\
\hline \multicolumn{6}{|c|}{ Test for overall effect: $Z=1.34(P=0.18)$} \\
\hline \multicolumn{6}{|l|}{3 Mixed } \\
\hline Fish 2001 & $16 / 476$ & $16 / 472$ & & $100.0 \%$ & $0.99[0.50,1.96]$ \\
\hline Subtotal (95\% CI) & 476 & 472 & & $100.0 \%$ & $0.99[0.50,1.96]$ \\
\hline \multicolumn{6}{|c|}{ Total events: 16 (LABA + ICS), I6 (LTRA + ICS) } \\
\hline \multicolumn{6}{|c|}{ Heterogeneity: not applicable } \\
\hline \multicolumn{6}{|c|}{ Test for overall effect: $Z=0.02(P=0.98)$} \\
\hline \multicolumn{6}{|l|}{4 Unclear } \\
\hline Nelson 2001 & $6 / 214$ & $7 / 215$ & & $100.0 \%$ & $0.86[0.29,2.52]$ \\
\hline Subtotal (95\% CI) & 214 & 215 & & $100.0 \%$ & $0.86[0.29,2.52]$ \\
\hline \multicolumn{6}{|c|}{ Total events: 6 (LABA + ICS), 7 (LTRA + ICS) } \\
\hline \multicolumn{6}{|c|}{ Heterogeneity: not applicable } \\
\hline \multicolumn{6}{|c|}{ Test for overall effect: $Z=0.27(P=0.78)$} \\
\hline Test for subgroup differenc & $2=0.39, \mathrm{df}=$ & 4), $\left.\right|^{2}=0.0 \%$ & & & \\
\hline
\end{tabular}

$\begin{array}{lllllll}0.1 & 0.2 & 0.5 & 1 & 2 & 5 & 10\end{array}$

Favours LABA + ICS Favours LTRA + ICS 
Analysis 2.3. Comparison 2 Subgroup and sensitivity analyses, Outcome 3 Participants with one or more exacerbations requiring systemic corticosteroids: study duration.

Review: Addition to inhaled corticosteroids of long-acting beta2-agonists versus anti-leukotrienes for chronic asthma

Comparison: 2 Subgroup and sensitivity analyses

Outcome: 3 Participants with one or more exacerbations requiring systemic corticosteroids: study duration

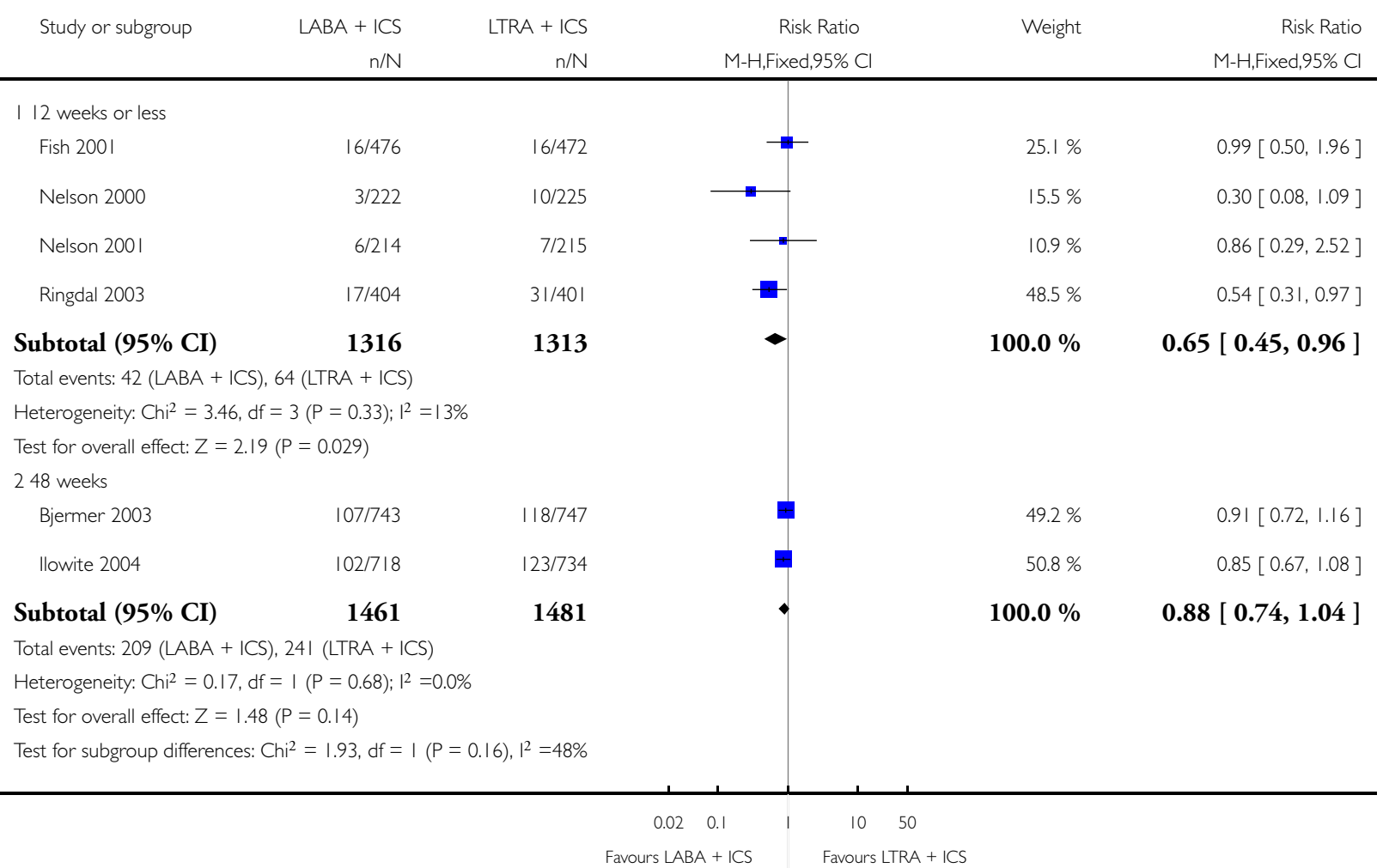


Analysis 2.4. Comparison 2 Subgroup and sensitivity analyses, Outcome 4 Serious adverse effects stratified by number of inhaler devices used for LABA + ICS.

Review: Addition to inhaled corticosteroids of long-acting beta2-agonists versus anti-leukotrienes for chronic asthma

Comparison: 2 Subgroup and sensitivity analyses

Outcome: 4 Serious adverse effects stratified by number of inhaler devices used for LABA + ICS

\begin{tabular}{|c|c|c|c|c|c|}
\hline \multirow[t]{2}{*}{ Study or subgroup } & $L A B A+I C S$ & LTRA + ICS & \multirow{2}{*}{$\begin{array}{r}\text { Risk Ratio } \\
\text { IV,Fixed,95\% Cl }\end{array}$} & \multirow[t]{2}{*}{ Weight } & \multirow{2}{*}{$\begin{array}{r}\text { Risk Ratio } \\
\text { IV,Fixed,95\% Cl }\end{array}$} \\
\hline & $\mathrm{n} / \mathrm{N}$ & $\mathrm{n} / \mathrm{N}$ & & & \\
\hline \multicolumn{6}{|c|}{ I Single device for $L A B A+I C S$} \\
\hline Ringdal 2003 & $4 / 404$ & $7 / 401$ & & $70.1 \%$ & $0.57[0.17,1.92]$ \\
\hline Nelson 2000 & $1 / 222$ & $2 / 225$ & + & $18.2 \%$ & $0.51[0.05,5.55]$ \\
\hline Pavord 2007 & $2 / 33$ & $0 / 33$ & $\longrightarrow$ & $11.6 \%$ & $5.00[0.25,100.32]$ \\
\hline Subtotal $(95 \% \mathrm{CI})$ & 659 & 659 & & $100.0 \%$ & $0.72[0.26,1.99]$ \\
\hline \multicolumn{6}{|c|}{ Total events: 7 (LABA + ICS), 9 (LTRA + ICS) } \\
\hline \multicolumn{6}{|c|}{ Heterogeneity: Chi $^{2}=1.83, d f=2(P=0.40) ;\left.\right|^{2}=0.0 \%$} \\
\hline \multicolumn{6}{|c|}{ Test for overall effect: $Z=0.64(P=0.52)$} \\
\hline \multicolumn{6}{|c|}{2 Two devices for LABA + ICS } \\
\hline Nelson 2001 & $1 / 214$ & $1 / 215$ & & $1.3 \%$ & $1.00[0.06,15.96]$ \\
\hline Fish 2001 & $5 / 476$ & $5 / 472$ & 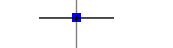 & $6.7 \%$ & $0.99[0.29,3.40]$ \\
\hline Bjermer 2003 & $55 / 743$ & $34 / 747$ & $\theta$ & $58.9 \%$ & $1.63[1.07,2.46]$ \\
\hline llowite 2004 & $27 / 730$ & $22 / 743$ & 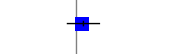 & $33.1 \%$ & $1.25[0.72,2.17]$ \\
\hline Subtotal (95\% CI) & 2163 & 2177 & $\bullet$ & $100.0 \%$ & $1.43[1.04,1.97]$ \\
\hline \multicolumn{6}{|c|}{ Total events: 88 (LABA + ICS), 62 (LTRA + ICS) } \\
\hline \multicolumn{6}{|c|}{ Heterogeneity: $\mathrm{Chi}^{2}=1.00, \mathrm{df}=3(\mathrm{P}=0.80) ; \mathrm{I}^{2}=0.0 \%$} \\
\hline \multicolumn{6}{|c|}{ Test for overall effect: $Z=2.21(P=0.027)$} \\
\hline Test for subgroup differen & $i^{2}=1.61, d f=1$ & $0), 1^{2}=38 \%$ & & & \\
\hline
\end{tabular}

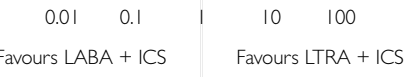


Analysis 3.I. Comparison 3 MD archive from previous review version, Outcome I Morning PEF (L/min) change from baseline.

Review: Addition to inhaled corticosteroids of long-acting beta2-agonists versus anti-leukotrienes for chronic asthma

Comparison: $3 \mathrm{MD}$ archive from previous review version

Outcome: I Morning PEF ( $L / \mathrm{min})$ - change from baseline

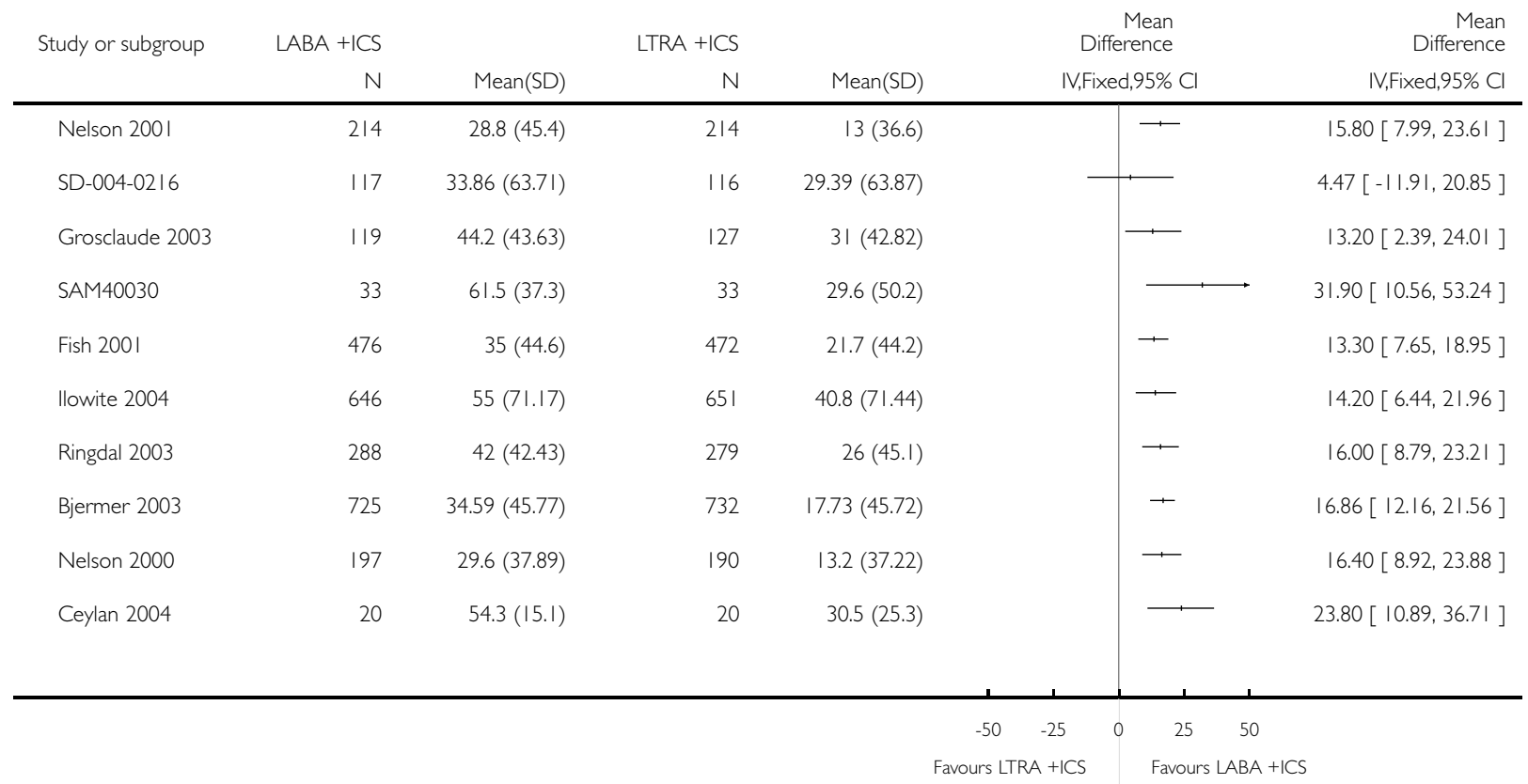


Analysis 3.2. Comparison 3 MD archive from previous review version, Outcome 2 Evening PEF (L/min) change from baseline.

Review: Addition to inhaled corticosteroids of long-acting beta2-agonists versus anti-leukotrienes for chronic asthma

Comparison: 3 MD archive from previous review version

Outcome: 2 Evening PEF ( $L / \mathrm{min})$ - change from baseline

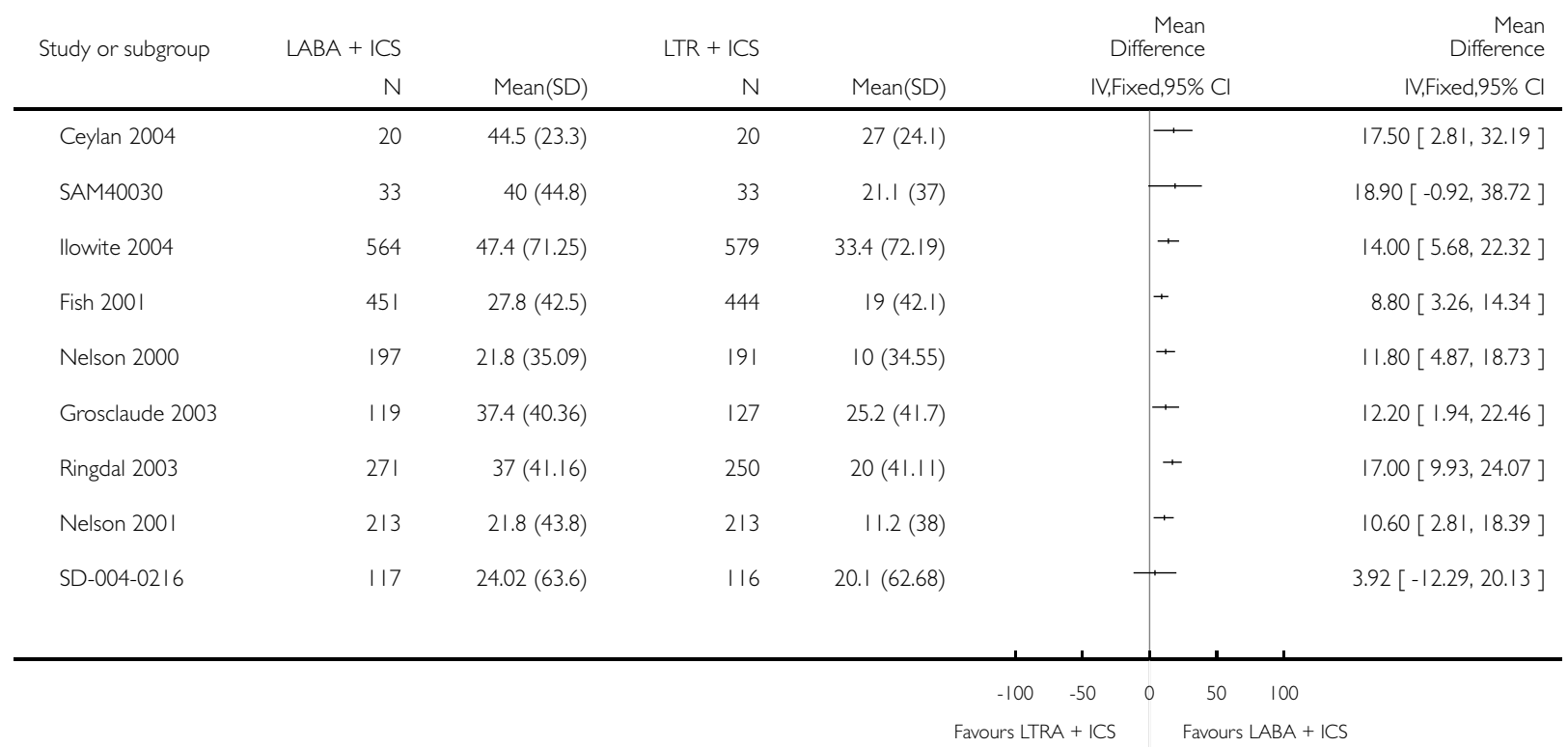


Analysis 3.3. Comparison 3 MD archive from previous review version, Outcome 3 FEVI (L) - change from baseline.

Review: Addition to inhaled corticosteroids of long-acting beta2-agonists versus anti-leukotrienes for chronic asthma

Comparison: $3 \mathrm{MD}$ archive from previous review version

Outcome: $3 \mathrm{FEVI}(\mathrm{L})$ - change from baseline

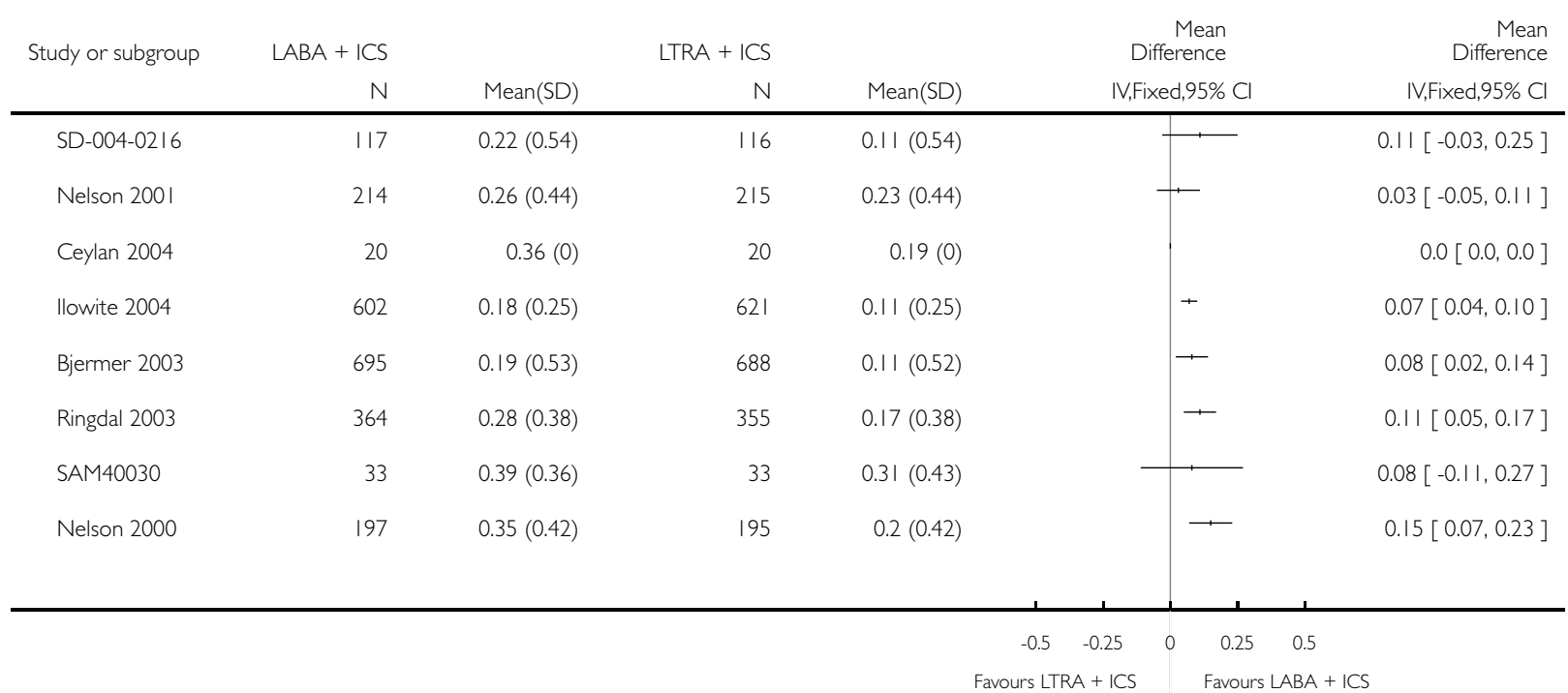




\section{Analysis 3.4. Comparison 3 MD archive from previous review version, Outcome 4 Symptom free days (\%) - change from baseline.}

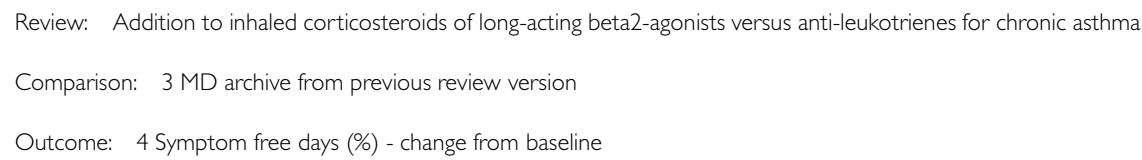

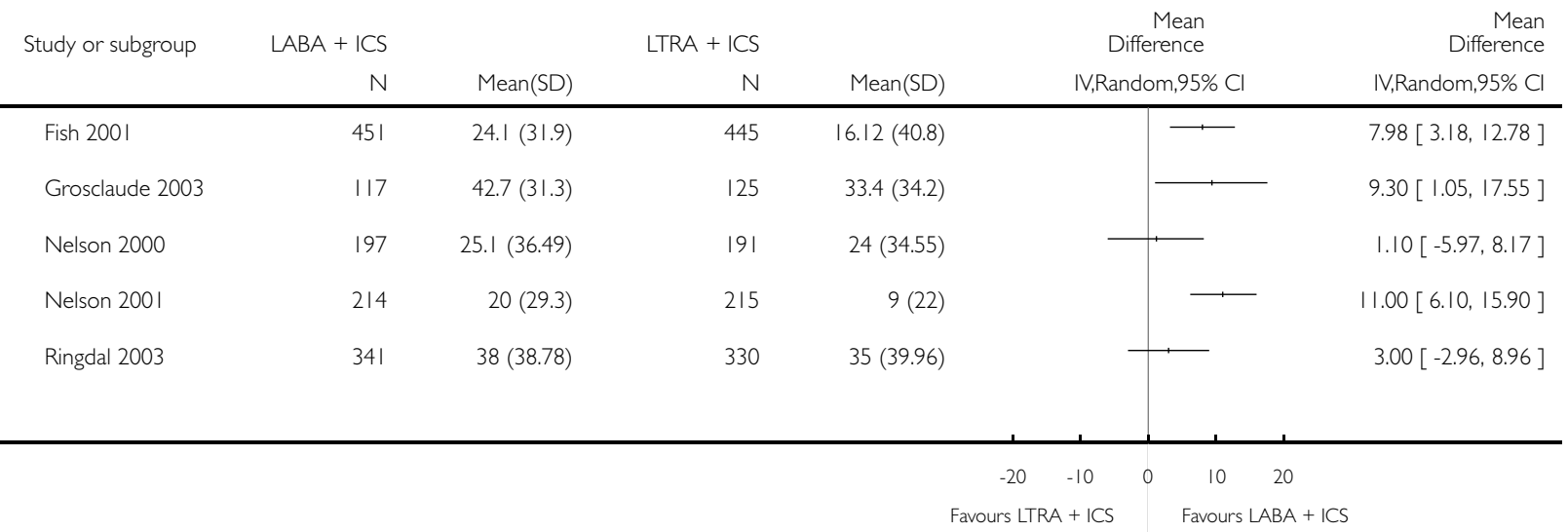

ADDITIONAL TABLES

Table 1. Search history

\begin{tabular}{|c|c|}
\hline Years & Detail \\
\hline All years to January 2004 & $\begin{array}{l}\text { Citations: } 184 \text { ( } 181 \text { from the literature search and three unpublished trials provided by pharmaceu- } \\
\text { tical companies for a total of } 184 \text { citations) } \\
\text { Citations excluded: } 172 \text { : ( } 1) \text { duplicate citations }(\mathrm{N}=29) \text {, (2) abstracts of considered full-text publi- } \\
\text { cations or secondary analyses of the same study }(\mathrm{N}=18) \text {, (3) not a randomised controlled trial }(\mathrm{N}= \\
72) \text {, (4) protocol of ongoing trial }(\mathrm{N}=1),(5) \text { no consistent co-treatment with inhaled glucocorticoids } \\
(\mathrm{N}=21) \text {, (6) one of the tested interventions was not daily LTRA }(\mathrm{N}=18) \text {, ( } 7) \text { one of the tested } \\
\text { interventions was not daily LABA }(\mathrm{N}=5),(8) \text { interventions were administered for less than } 4 \text { weeks } \\
(\mathrm{N}=6) \text {, and (9) use of prohibited co-interventions such as LABA in both groups ( } \mathrm{N}=2) \text {. } \\
\text { Studies meeting the entry criteria of the review: } 12 \text { (six full-text publications (Bjermer 2003; Fish } \\
\text { 2001; Ilowite 2004; Nelson 2000; Nelson } 2001 \text {; Ringdal 2003), two unpublished full-text reports } \\
\text { (Hultquist 2000; McCarthy 2003) and four abstracts (Gold (abs) 2001; Green (abs) 2002; Leibman } \\
\text { (abs) 2002; Nsouli 2001). The abstracts did not provide data in sufficient detail to contribute to } \\
\text { the meta-analyses }\end{array}$ \\
\hline January 2004 to January 2006 & $\begin{array}{l}\text { Citations: } 60 \text {. } \\
\text { Citations excluded: } 55 \text { : the study was a duplicate (i.e. identical citation of one trial report, or a } \\
\text { subsequent report of a trial) }(\mathrm{N}=22) \text {; the study was not randomised }(\mathrm{N}=2) \text {; the study was } \\
\text { ongoing }(\mathrm{N}=5) \text {; the administration of either LTRA or LABA was not standardised across treatment } \\
\text { groups }(\mathrm{N}=3) \text {; there was no consistent co-treatment with inhaled glucocorticoids }(\mathrm{N}=8) \text {; one }\end{array}$ \\
\hline
\end{tabular}


Table 1. Search history (Continued)

of the tested interventions was not daily LTRA as add-on to inhaled glucocorticoids $(\mathrm{N}=9)$; one of the tested interventions was not daily LABA as add-on to inhaled glucocorticoids $(\mathrm{N}=2)$; the tested interventions were administered for less than 4 weeks $(\mathrm{N}=1)$; the study used prohibited cointervention (i.e., maintenance oral steroids, theophylline, non-steroidal anti-inflammatory drugs, anticholinergics $)(\mathrm{N}=3)$

Table 2. ICS at CFC-BDP equivalent dose ( $\mu$ g/day)

\begin{tabular}{|c|c|c|c|c|}
\hline Study & $\begin{array}{l}\text { Actual dose of ICS (total } \\
\text { per day) }\end{array}$ & $\begin{array}{l}\text { CFC- BDP equivalent / } \\
\text { day }\end{array}$ & Population & Low/medium/high \\
\hline Bjermer 2003 & $200 \mathrm{mcg}$ fluticasone & $400 \mathrm{mcg}$ & Adults & Low \\
\hline Ceylan 2004 & $400 \mathrm{mcg}$ budesonide & $400 \mathrm{mcg}$ & Adults & Low \\
\hline Fish 2001 & $\begin{array}{l}\text { Range of doses between } \\
175 \text { to } 1700 \mathrm{mcg}\end{array}$ & $560 \mu g$ (range $175-1700)$ & Adults & Mixed \\
\hline Gold 2001 & $100 \mathrm{mcg}$ fluticasone & $200 \mathrm{mcg}$ & Adults & Low \\
\hline Green 2006 & 200mcg budesonide & $200 \mathrm{mcg}$ & Adults & Low \\
\hline Grosclaude 2003 & $\begin{array}{l}1000 \mathrm{mcg} \text { CFC BDP and } \\
\text { fluticasone } 500 \mathrm{mcg}\end{array}$ & $1000 \mathrm{mcg}$ & Adults & High \\
\hline Hendeles 2004 & $250 \mathrm{mcg}$ fluticasone & $500 \mathrm{mcg}$ & Adults & Medium \\
\hline Ilowite 2004 & $250 \mathrm{mcg}$ fluticasone & $500 \mathrm{mcg}$ & Adults & Medium \\
\hline Lemanske 2010 & $200 \mathrm{mcg}$ fluticasone & $400 \mathrm{mcg}$ & Children & Low \\
\hline Nelson 2000 & $200 \mathrm{mcg}$ fluticasone & $400 \mathrm{mcg}$ & Adults & Low \\
\hline Nelson 2001 & not specified & $\begin{array}{l}\text { requested from author } 08 / \\
03\end{array}$ & Adults & Unclear \\
\hline Nsouli 2001 & Unclear & $500 \mathrm{mcg}$ & Adults & Unclear \\
\hline Pavord 2007 & $200 \mathrm{mcg}$ fluticasone & $400 \mathrm{mcg}$ & Adults & Low \\
\hline Ringdal 2003 & $200 \mathrm{mcg}$ fluticasone & $400 \mathrm{mcg}$ & Adults & Low \\
\hline SAM 40030 & $200 \mathrm{mcg}$ fluticasone & $400 \mathrm{mcg}$ & Adults & Low \\
\hline SD-004-0216 & $400 \mathrm{mcg}$ budesonide & $400 \mathrm{mcg}$ & Adults & Low \\
\hline ELEVATE & Unclear & Unclear & Adults & Unclear \\
\hline
\end{tabular}


Table 2. ICS at CFC-BDP equivalent dose ( $\mu$ g/day) (Continued)

\begin{tabular}{|c|c|c|c|c|}
\hline Storms 2004 & $200 \mathrm{mcg}$ fluticasone & $400 \mathrm{mcg}$ & Adults & Low \\
\hline
\end{tabular}

\section{A P PEN D I CES}

\section{Appendix I. GSK randomisation procedures}

The procedures for randomising GSK sponsored studies has been detailed in correspondence between Richard Follows and TL, the details of which are given below:

The randomisation software is a computer-generated, centralised programme (RandAll). After verification that the randomisation sequence is suitable for the study design (crossover, block or stratification), Clinical Supplies then package the treatments according the randomisation list generated. Concealment of allocation is maintained by a third party, since the sites phone in and are allocated treatments on that basis. Alternatively a third party may dispense the drug at the sites. Unblinding of data for interim analyses can only be done through RandAll, and are restricted so that only those reviewing the data are unblinded to treatment group allocation.

\section{WHAT'S NEW}

Last assessed as up-to-date: 16 March 2010.

\begin{tabular}{lll}
\hline Date & Event & Description \\
\hline 5 July 2011 & Amended & Clarification made to abstract regarding subgroup analysis. \\
\hline
\end{tabular}

\section{H I S T O R Y}

Protocol first published: Issue 3, 2003

Review first published: Issue 1, 2005

\begin{tabular}{l|l|l}
\hline Date & Event & Description \\
\hline 2 February 2011 & New citation required and conclusions have changed & $\begin{array}{l}\text { Full risk of bias assessment has been incorporated into } \\
\text { the review } \\
\text { Data on secondary outcomes were provided by the new } \\
\text { studies. Serious adverse events are more common with } \\
\text { LABA and ICS than LTRA and ICS. This result is not } \\
\text { definitive and could be influenced by separate adminis- } \\
\text { tration of LABA and ICS }\end{array}$ \\
& &
\end{tabular}




\begin{tabular}{l|l|l}
\hline 4 August 2008 & Amended & Converted to new review format. \\
\hline 20 June 2006 & New citation required and conclusions have changed & $\begin{array}{l}\text { Five new studies met the entry criteria of the review } \\
\text { (Ceylan 2004; Grosclaude 2003; Hendeles 2004; Stel- } \\
\text { mach 2008a; Storms 2004). Of these, two studies con- } \\
\text { tributed data to this updated review. The additional data } \\
\text { did not alter the conclusions of the review }\end{array}$ \\
\hline
\end{tabular}

\section{CONTRIBUTIONSOFAUTHORS}

Francine M Ducharme reviewed the protocol design; supervised the literature search; reviewed all citations; participated in the selection of trials, methodology assessment, and data extraction; corresponded with authors and pharmaceutical companies to identify other relevant trials, verify methodology and data extraction, and request additional information; analysed and interpreted results of the metaanalysis; and edited the final review.

Toby Lasserson (update 2006, 2010) assessed studies for inclusion or exclusion, extracted and entered data, revised results and discussion sections, and solicited additional data from authors.

Christopher Cates edited the review, checked the methodology, and contributed to writing up the final review.

Felix Ram participated in the initial version of the review (2005): protocol design, identified and reviewed the full-text publication of all citations of potential or potentially eligible RCTs, extracted the methodology and data, analysed and interpreted results of the metaanalysis, and wrote the first draft of the review.

\section{DECLARATIONS OF INTEREST}

Francine M Ducharme has received travel support for meeting attendance, research funds, fees for speaking and consulting fees from Merck Frosst Inc (producer of montelukast), GlaxoSmithKline (producer of fluticasone, beclomethasone, salmeterol), Novartis (producer of formoterol) and Nycomed (producer of combination of mometasone and formoterol). No conflict was reported by Toby Lasserson or Christopher Cates.

\section{SOURCES OF SUPPORT}




\section{Internal sources}

- No sources of support supplied

\section{External sources}

- Nederlands Astma Fonds, Netherlands.

- Francine M. Ducharme, Canada.

- NHS Research and Development, UK.

\section{DIFFERENCES BETWEEN PROTOCOLANDREVIEW}

1. In the protocol published in April 2001, we had planned to examine the impact of the inhaled glucocorticoids (subgroups 3) and of baseline severity (subgroups 5) as sensitivity analyses but changed to subgroup analyses because this enhanced the clarity of interpretation. The last two subgroup analyses $(6 \& 7)$, not initially considered in 2001 , were added to the list subsequently as recent data indicated that the number of inhaler devices to deliver LABA + ICS might be an important effect modifier (Nelson 2003), and a peer reviewer suggested that differences might not be the same over 12 and 48 weeks.

2. Due to recent concerns over the association between LABAs and serious adverse events, we included a subgroup analysis of the data by the number of inhaler devices.

3. Study assessment was amended to reflect changes in the recommended approach to risk of bias evaluation. In the original protocol and first version of the review we assessed studies with the Jadad scale, and by grading concealment of allocation. For the 2010 update we have used a tool for assessing the degree of protection offered by the study design against systematic error. This is outlined in the section: Assessment of risk of bias in included studies.

\section{NDEX TERMS}

\section{Medical Subject Headings (MeSH)}

Adrenal Cortex Hormones [*therapeutic use]; Adrenergic beta-2 Receptor Agonists [*therapeutic use]; Anti-Asthmatic Agents [*therapeutic use]; Asthma [*drug therapy]; Chronic Disease; Drug Therapy, Combination; Leukotriene Antagonists [*therapeutic use]; Randomized Controlled Trials as Topic

\section{MeSH check words}

Adolescent; Adult; Child; Humans 